UNIVERSIDADE DE SÃO PAULO

ESCOLA DE ENFERMAGEM

CARLA ANDREA TRAPÉ

OPERACIONALIZAÇÃO DO CONCEITO DE CLASSES SOCIAIS EM EPIDEMIOLOGIA CRÍTICA: UMA PROPOSTA DE APROXIMAÇÃO A PARTIR DA CATEGORIA REPRODUÇÃ̃ SOCIAL

SÃO PAULO

2011 


\title{
OPERACIONALIZAÇÃO DO CONCEITO DE CLASSES SOCIAIS EM EPIDEMIOLOGIA CRÍTICA: UMA PROPOSTA DE APROXIMAÇÃO A PARTIR DA CATEGORIA REPRODUÇÃO SOCIAL
}

\author{
Tese apresentada à Escola de Enfermagem \\ da Universidade de São Paulo para \\ obtenção do título de Doutor em Ciências \\ Área de concentração: \\ Cuidado em Saúde \\ Orientadora: \\ Prof $^{\text {a. }}$ Dr $^{\text {a }}$. Cássia Baldini Soares
}

SÃO PAULO 


\begin{abstract}
AUTORIZO A REPRODUÇÃO E DIVULGAÇÃO TOTAL OU PARCIAL DESTE TRABALHO, POR QUALQUER MEIO CONVENCIONAL OU ELETRÔNICO, PARA FINS DE ESTUDO E PESQUISA, DESDE QUE CITADA A FONTE.
\end{abstract}

Assinatura:

Data:

\title{
Catalogação na Publicação (CIP) \\ Biblioteca "Wanda de Aguiar Horta" \\ Escola de Enfermagem da Universidade de São Paulo
}

Trapé, Carla Andrea

Operacionalização do conceito de classes sociais em epidemiologia crítica: uma proposta de aproximação a partir da categoria reprodução social / Carla Andrea Trapé. -- São Paulo, 2011.

235. p.

Tese (Doutorado) - Escola de Enfermagem da Universidade de São Paulo.

Área: Enfermagem em saúde coletiva

Orientadora: $\operatorname{Prof}^{\mathrm{a}} \operatorname{Dr}^{\mathrm{a}}$ Cássia Baldini Soares

1. Classes sociais 2. Epidemiologia 3. Estatística

4. Grupos sociais 5. Saúde 6. Informação I. Título. 
Carla Andrea Trapé

Operacionalização do conceito de classes sociais em Epidemiologia Crítica: Uma proposta de aproximação a partir da categoria reprodução social

Tese apresentada à Escola de Enfermagem da Universidade de São Paulo para obtenção do título de Doutor em Ciências

Área de Concentração: Cuidado em Saúde

Aprovado em:

Banca Examinadora

Prof. Dr. Instituição:

Julgamento: Assinatura:

Prof. Dr. Instituição:

Julgamento: Assinatura:

Prof. Dr. Instituição:

Julgamento: Assinatura:

Prof. Dr. Instituição:

Julgamento: Assinatura:

Prof. Dr. Instituição:

Julgamento: Assinatura: 


\section{AGRADECIMENTOS}

À prof ${ }^{\text {a. }}$ Dr a. Cássia Baldini Soares pela amizade e por tudo que me ensinou para além da academia, me guiando desde a graduação com sua presença constante e extrema competência no processo de consolidação da minha visão de mundo e de formação contínua como trabalhadora no campo da saúde coletiva.

À Elaine Minuci por sua imprescindível contribuição nas análises estatísticas.

À Tatiana Yonekura e à Profa. Dra. Célia Maria Sivalli Campos por suas importantes observações e contribuições durante todo trabalho.

Ao prof. Dr. Francisco Antônio de Castro Lacaz e profa. Dra. Ana Luiza Vilela Borges pelas essenciais contribuições.

A todos os integrantes do grupo de pesquisa pelas discussões e trocas de experiência.

Aos meus pais, à minha irmã e toda minha família por acreditarem em mim.

Ao Adnan, grata surpresa da vida, que esteve ao meu lado me incentivando durante a finalização desse trabalho. 
Aos integrantes da minha equipe (hoje e sempre) - Ana Rosa, João, Lenise, Márcia Oliveira, Márcia Julião, Nice, Marília, Clarissa, Jerry, Juliana, Thais, Léo - pela torcida, companheirismo e total apoio em diversos momentos.

A todos os amigos da UBS Jd. Boa Vista pelo apoio e compreensão durante todo o processo, principalmente à Ana Emília, Ângela, Bruna, Denise, Edileuza, Silene, Juscilaynne. À lara e Ana Cláudia pelas discussões enriquecedoras que têm me fortalecido na consolidação do referencial teórico no qual acredito.

À minhas amigas Irene, Liliam, Érica, Gisele e Reneide pelo apoio e incentivo.

Aos meus amigos de sempre Adriana, Eduardo e Audrey que estão ao meu lado desde o colégio.

À Fundação de Amparo à Pesquisa de São Paulo (FAPESP) pelo financiamento do projeto matriz (Processo:0651671-9). 
Quem construiu Tebas, a das sete portas?

Nos livros vem o nome dos reis, mas foram os reis que transportaram as pedras?

Babilônia, tantas vezes destruída, quem outras tantas a reconstruiu? Em que casas da Lima Dourada moravam seus obreiros? No dia em que ficou pronta a Muralha da China para onde foram os seus pedreiros? A grande Roma está cheia de arcos de triunfo. Quem os ergueu? Sobre quem triunfaram os Césares? A tão cantada Bizâncio só tinha palácios para os seus habitantes? Até a legendária Atlântida na noite em que o mar a engoliu viu afogados gritar por seus escravos.

O jovem Alexandre conquistou as Índias Sozinho?

César venceu os gauleses.

Nem sequer tinha um cozinheiro ao seu serviço?

Quando a sua armada se afundou Filipe de Espanha chorou. E ninguém mais?

Frederico II ganhou a guerra dos sete anos, quem mais a ganhou?

Em cada página uma vitória.

Quem cozinhava os festins?

Em cada década um grande homem.

Quem pagava as despesas?

Tantas histórias

Quantas perguntas

\section{Perguntas de um Operário Letrado Bertolt Brecht}




\section{Trapé CA. A operacionalização do conceito de classes sociais em epidemiologia crítica: uma proposta de aproximação a partir da categoria reprodução social [tese]: São Paulo, Escola de Enfermagem, Universidade de São Paulo; 2011}

\section{RESUMO}

O presente trabalho toma por objeto a operacionalização do conceito de classes por meio da definição de variáveis para classificação da população em grupos sociais. $\mathrm{O}$ estudo apóia-se no arcabouço teórico-metodológico da Epidemiologia Crítica que fundamenta-se numa compreensão de saúde e doença que coloca no centro da explicação dos determinantes da saúde, o trabalho - a produção capitalista - e, a ele subordinado, a vida - o consumo sob o comando do processo de acumulação capitalista. Esta investigação pretende averiguar a capacidade das variáveis de trabalho e vida reprodução social - de mostrar as diferenças de reprodução social das famílias e apoiar a operacionalização do conceito de classe na contemporaneidade. Tem por objetivos específicos: a) levantar por meio de inquérito domiciliar variáveis de reprodução social de famílias que vivem em diferentes espaços sociais de uma cidade da Região Metropolitana de São Paulo; b) analisar o comportamento dessas variáveis de reprodução social quanto à sua capacidade para formar grupos com semelhantes formas de trabalhar e de viver; c) construir um índice de reprodução social capaz de mostrar as diferenças de reprodução social entre as famílias no micro espaço. Partiu-se de arcabouço proposto na literatura, para criar grupos sociais homogêneos, definindo-se um conjunto de 37 variáveis de formas de trabalhar e de viver, que foram coletadas em uma amostra de 589 famílias de Santo André. A amostra foi definida proporcionalmente de acordo com quatro grupos sociais de Santo André - grupo central, quase central, quase periférico e periférico - divididos a priori por meio de estudo anterior. Dessa forma, a totalidade das famílias divididas em grupos sociais foi entrevistada por meio de questionário com variáveis de produção e de consumo. Tais variáveis submetidas à análise estatística demonstraram que, desse conjunto, a dimensão da produção foi definida pela condição de atividade do chefe de família, qualificação da ocupação e curso preparatório para o trabalho. Já a dimensão do consumo foi definida pelas variáveis propriedade da residência, número de cômodos para dormir, acesso a serviço público de esgoto, legalidade do acesso à água e luz, pagamento de IPTU e culto como atividade de lazer. A partir dessas variáveis capazes de classificar as famílias foram então gerados quatro novos grupos e construído o Índice de Reprodução Social - IRS - 
que se mostra um importante instrumento capaz de mostrar as diferenças de reprodução social de modo a possibilitar o mapeamento dos perfis de reprodução social no micro espaço que, em conjunto com os perfis de saúde-doença, proporciona a construção dos perfis epidemiológicos que embasem tanto o planejamento no âmbito do serviço de saúde quanto o planejamento de políticas públicas voltadas para os determinantes sociais do processo saúde-doença.

Palavras-chave: classes sociais, epidemiologia, estatística, grupos sociais, saúde, informação 
Trapé CA. The measurement of social class in critical epidemiology: a proposal of approximation from the category of social reproduction [thesis]: São Paulo, Escola de Enfermagem, Universidade de São Paulo; 2011

\begin{abstract}
This work takes as its object of study the operationalization of the concept of classes by defining cutoff variables for classifying the population in social groups. The study is based upon theoretical and methodological of critical epidemiology is based on an understanding of health and illness by focusing the explanation of health determinants, work - the capitalist production - and subordinated to it, life - consumption under the command of the capitalist accumulation process. This research aims to assess the overall potential of work-life variables - social reproduction - to show class inequalities and support the operationalization of the concept of classes in contemporary society. Its specific objectives: a) take a household poll on the variables of social reproduction of families living in different social spaces in a city in the metropolitan region, b) analyze the behavior of these social reproduction variables on their ability to form groups with similar forms of working and living; c) construct a social reproduction index able to show the differences of social reproduction among families in micro space. It started from the framework proposed in the literature to form homogenous social groups, defining a set of 34 variables on the ways of working and living, which were collected in a sample of 589 families from Santo André. The sample was proportionally defined according to four social groups from Santo André - the central group, almost central, peripheral and almost peripheral - a priori divided by the previous study. Thus, all the families divided into social groups were interviewed using a questionnaire with variables of production and consumption. These variables were subjected to statistical analysis which showed that in this scenario, the dimension of the forms of work was defined by the activity status of the household head, occupation qualification, and preparatory courses for the job. The dimension of the forms of living was defined by the variables: residence ownership, access to public sewage service, legal access to water and light, church services as a leisure activity, payment of property taxes and number of rooms for sleeping. Then, we generated four new groups. Based on these powerful variables to characterize the groups, we were able to build the Social Reproduction
\end{abstract}


Index - SRI - able to show the social reproduction differences among families in the micro-space of the area covered by a Basic Health Unit. It has to be noticed that the variables were not analyzed from their behavior in the four isolated groups, but from the relationship among them and the way this relationship is given in each group. The SRI seems to be a powerful tool for the classification of families in order to enable the mapping of social reproduction profiles in micro space that along with profiles of health and disease provides the construction of the epidemiological profiles able to bolster both the planning within the health service and the planning of public policies aimed to the social determinants of health-disease process.

Keywords: social class, epidemiology, statistical, social groups, health, information 


\section{LISTA DE SIGLAS}

\begin{tabular}{|c|c|c|}
\hline ABIPEME & - & Associação Brasileira dos Institutos de Pesquisa de Mercado \\
\hline BNDES & - & Banco Nacional de Desenvolvimento \\
\hline $\mathrm{CBO}$ & - & Classificação Brasileira de Ocupações \\
\hline ENDEF & - & Estudo Nacional de Despesa Familiar \\
\hline FTE & - & Formas de trabalhar estáveis \\
\hline FTI & - & Formas de trabalhar instáveis \\
\hline FVE & - & Formas de viver estáveis \\
\hline FVI & - & Formas de viver instáveis \\
\hline GSH & - & Grupo Social Homogêneo \\
\hline IBGE & - & Instituto Brasileiro de Geografia e Estatística \\
\hline INSS & - & Instituto Nacional de Seguridade Social \\
\hline IPTU & - & Imposto Predial Territorial Urbano \\
\hline IRS & - & Índice de Reprodução Social \\
\hline LDB & - & Lei de Diretrizes e Bases \\
\hline ONG & - & Organização Não Governamental \\
\hline PCIC & - & Proposta de Construção de Indicadores Compostos \\
\hline PLANFOR & - & Plano Nacional de Qualificação do Trabalhador \\
\hline PNAD & - & Pesquisa Nacional por Amostra de Domicílios \\
\hline PNSN & - & Pesquisa Nacional de Saúde e Nutricional \\
\hline REDE & - & Região de Dados Estatísticos \\
\hline RFPC & - & Renda familiar per Capita \\
\hline RMSP & - & Região Metropolitana de São Paulo \\
\hline SEADE & - & Fundação Sistema Estadual de Análise de Dados \\
\hline SEFOR & - & Secretaria de Formação e Desenvolvimento Profissional \\
\hline SPSS & - & Statistical Package of Social Scienses \\
\hline
\end{tabular}




\section{LISTA DE QUADROS}

Quadro 1- Definição das diferentes propostas latino-americanas de operacionalização do conceito de classe de acordo com a estrutura de classe e diferença entre classes e a inserção na produção.

Quadro 2 - Categorias analíticas, categorias empíricas, variáveis para formas de trabalhar e de viver e variáveis de corte utilizadas para definir a heterogeneidade do coletivo.

Quadro 3 - Limites de exclusão/inclusão das variáveis de corte para formas de trabalhar, utilizados na operacionalização da heterogeneidade do coletivo segundo a inserção no momento da produção.

Quadro 4 - Limites de exclusão/inclusão das variáveis de corte para formas de viver, utilizados na operacionalização da heterogeneidade do coletivo segundo a inserção no momento do consumo.

Quadro 5 - Classificação das famílias estudadas em grupos sociais homogêneos, segundo suas formas de trabalhar e de viver.

Quadro 6 - Instituições em que se realizaram a coleta de dados.

Quadro 7- Distribuição dos jovens de 15 a 24 anos nos quatro grupos sociais originais.

Quadro 8- Amostra planejada e distribuída nos quatro grupos sociais originais.

Quadro 9 - Distribuição das famílias dos quatro grupos sociais segundo posse de bens e presença de empregados mensalistas no domicílio.

Quadro 10- Porcentual das famílias dos quatro grupos sociais segundo meios de transporte utilizados para ir ao trabalho/escola.

Quadro 11 - Porcentual de famílias dos quatro grupos sociais segundo atividades de lazer.

Quadro 12 - Porcentual de famílias que declararam estar expostas a algum tipo de risco.

Quadro 13- Percentual de famílias dos quatro grupos sociais que relataram alguma forma de participação social.

Quadro 14- Percentual de famílias dos quatro grupos sociais que relataram a utilização de instituições. 
Quadro 15- Varáveis importantes para compor as dimensões da produção e do consumo.

Quadro 16- Variáveis da dimensão da produção com os respectivos valores dos qualificadores.

Quadro 17- Variáveis da dimensão do consumo com os respectivos valores dos qualificadores.

Quadro 18 - Equações para classificação das famílias nos quatro grupos sociais. 


\section{LISTA DE TABELAS}

Tabela 1- Distribuição das famílias nos quatro grupos sociais originais gerados a partir de dados secundários do IBGE.

Tabela 2- Distribuição das famílias nos quatro novos grupos sociais gerados a partir das variáveis de formas de trabalhar e de viver.

Tabela 3- Distribuição das famílias dos quatro novos grupos sociais pelos bairros classificados segundo sua posição no território.

Tabela 4 - Distribuição dos indivíduos dos quatro novos grupos sociais segundo sexo 97 do chefe de família.

Tabela 5 - Distribuição dos indivíduos dos quatro novos grupos sociais segundo raça.

Tabela 6 - Distribuição dos indivíduos dos quatro novos grupos sociais segundo local de nascimento.

Tabela 7 - Distribuição dos indivíduos dos quatro novos grupos sociais segundo religião.

Tabela 8 - Distribuição dos chefes de família dos quatro novos grupos sociais segundo culto ou religião praticada.

Tabela 9 - Distribuição dos indivíduos dos quatro novos grupos sociais segundo escolaridade.

Tabela 10 - Distribuição dos chefes de família dos quatro novos grupos sociais segundo condição de atividade.

Tabela 11 - Distribuição dos chefes de família dos quatro novos grupos sociais segundo qualificação da ocupação.

Tabela 12 - Distribuição dos chefes de família dos quatro novos grupos sociais segundo ocupação.

Tabela 13 - Distribuição dos chefes de família dos quatro novos grupos sociais segundo realização de curso preparatório para o trabalho.

Tabela 14 - Distribuição dos chefes de família dos quatro novos grupos sociais segundo registro em carteira.

Tabela 15 - Distribuição das famílias dos quatro novos grupos sociais segundo faixa de renda familiar per capita.

Tabela 16- Distribuição dos chefes de família dos quatro novos grupos sociais segundo setor de trabalho. 
Tabela 17 - Distribuição dos chefes dos quatro novos grupos sociais segundo benefício oriundo do trabalho.

Tabela 18 - Distribuição das famílias dos quatro novos grupos sociais segundo material da habitação.

Tabela 19- Distribuição das famílias dos quatro novos grupos sociais segundo localização da moradia.

Tabela 20 - Distribuição das famílias dos quatro novos grupos sociais segundo propriedade da residência.

Tabela 21 - Distribuição das famílias dos quatro novos grupos sociais segundo pagamento do IPTU.

Tabela 22 - Distribuição das famílias dos quatro novos grupos sociais segundo motivo de mudança nos últimos cinco anos.

Tabela 23 - Distribuição das famílias dos quatro novos grupos sociais segundo acesso à água.

Tabela 24 - Distribuição das famílias dos quatro novos grupos sociais segundo acesso à luz.

Tabela 25 - Distribuição das famílias dos quatro novos grupos sociais segundo acesso a esgoto.

Tabela 26 - Distribuição das famílias dos quatro novos grupos sociais segundo destino do esgoto.

Tabela 27 - Distribuição das famílias dos quatro novos grupos sociais segundo destino do lixo.

Tabela 28 - Distribuição das famílias dos quatro novos grupos sociais segundo recebimento de conta de água.

Tabela 29 - Distribuição das famílias dos quatro novos grupos sociais segundo recebimento de conta de luz.

Tabela 30- Distribuição das famílias dos quatro novos grupos sociais segundo suficiência da renda para arcar com despesas básicas (alimentação, vestuário, contas de água e de luz).

Tabela 31- Distribuição das famílias dos quatro novos grupos sociais segundo posse de poupança ou aplicações financeiras.

Tabela 32- Distribuição das famílias dos quatro novos grupos sociais segundo referências a dívidas que não conseguem pagar. 
Tabela 33- Distribuição das famílias dos quatro novos grupos sociais segundo gastos com crediários ou empréstimos.

Tabela 34 - Comparação da distribuição das famílias entre os grupos gerados por clusters e os grupos gerados a partir da aplicação do IRS. 


\section{LISTA DE FIGURAS}

Figura 1- Distribuição das famílias nos quatro grupos obtidos com a aplicação do IRS. 


\section{Sumário}

Apresentação

1- Introdução

1.1. Relação entre inserção social e processo saúde-doença: perspectiva da Epidemiologia Crítica.

2 - Classes sociais: considerações teóricas 29

2.1 - Classe social a partir dos trabalhos de Marx, Weber, Thompson e Bourdieu ...32

2.1.1 - Classe social no âmbito da estrutura econômica - referencial marxista.......32

2.1.2- Classe social no âmbito do status e estilo de vida- Weber e Bourdieu .........37

2.1.3- Classe como ação social - Thompson ..........................................................42

2.2. Considerações a partir dos três referenciais .......................................................4 47

2.3. A centralidade do trabalho na sociologia contemporânea................................... 49

3- Utilização do conceito de classes sociais em investigações epidemiológicas na perspectiva da Epidemiologia crítica.

4- Aproximando-se da operacionalização do conceito de classe através da categoria reprodução social

4.1. Proposta de operacionalização da categoria reprodução social ..........................64

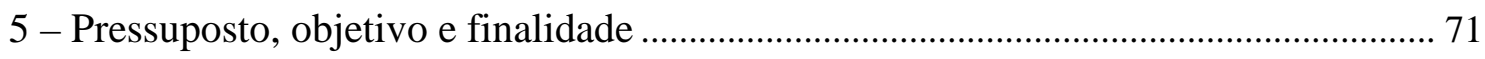

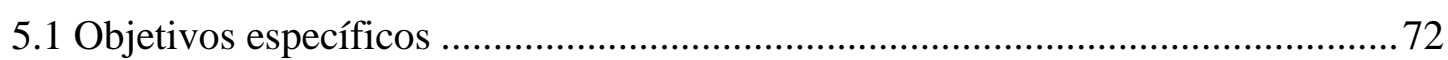

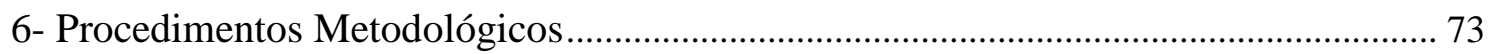

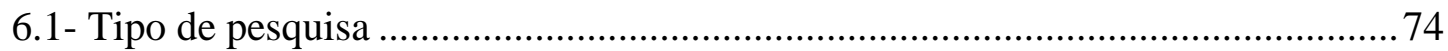

6.2- Caminho Percorrido ....................................................................................... 74

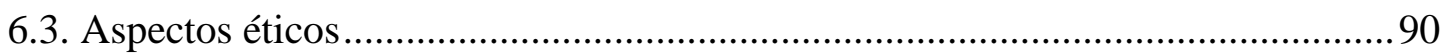

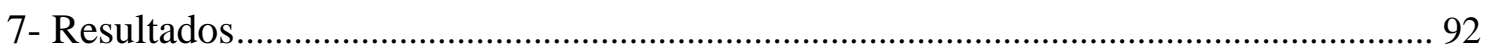

7.1- Comparação entre os grupos originais e os grupos novos: capacidade das variáveis de reprodução social de captar especificidades do micro espaço...............93

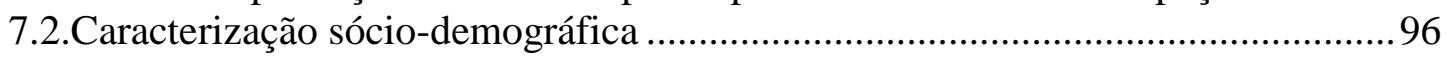

7.3- Formas de trabalhar- dimensão da produção ................................................100

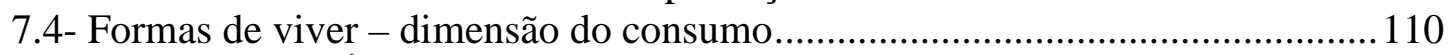

7.5- Construção do Índice de Reprodução Social (IRS) .......................................... 123

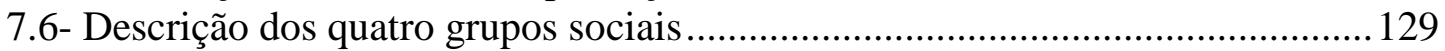

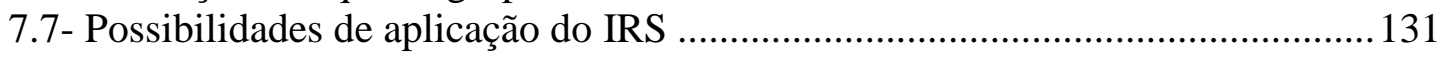

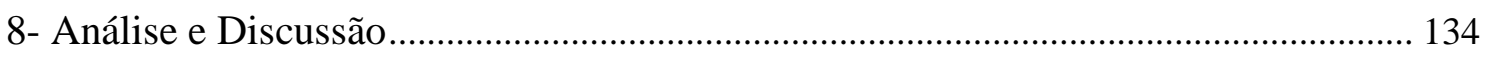

8.1- Distribuição dos grupos nos bairros estudados ............................................... 134 
8.2- Dimensão da produção

8.2. Dimensão do consumo

9- Considerações finais: para fazer a síntese

10- Referências 172

ANEXOS 182 


\section{Apresentação}

O presente trabalho inscreve-se no grupo de pesquisa "Fortalecimento e desgaste no trabalho e na vida: bases para a intervenção em Saúde Coletiva" e deriva do estudo "Jovens, valores e consumo de drogas: políticas públicas na perspectiva da saúde coletiva". Trata-se de um estudo desenvolvido no Município de Santo André, Região Metropolitana de São Paulo, que num primeiro momento construiu o Mapa das Juventudes de Santo André, recurso que mostrou as diferenças sociais entre os jovens moradores do município e serviu de apoio para decisões de caráter metodológico nessa investigação e em outras que se sucederam (Yonekura et al, 2010).

O projeto matriz pauta-se no entendimento de que o envolvimento dos jovens com o consumo prejudicial de drogas está relacionado com a crise/transição de valores contemporânea, considerando que os valores são estruturados, expressos e incorporados de formas diversas pelos jovens de diferentes classes sociais, em função das diferentes formas de reprodução social de suas famílias e das diferentes maneiras pelas quais as 'crises' de valores se apresentam.

Nessa perspectiva, a juventude não é tratada como etapa de um ciclo vital caracterizada pela puberdade, e sim como categoria social em que os jovens são sujeitos de classes sociais, ou seja, compõem diversas juventudes que se diferenciam pela sua condição de classe e que, apesar de terem em comum uma condição geracional, apresentam diferentes inserções no processo de reprodução social que determinam diferentes formas de viver o período de seu desenvolvimento humano (Soares, 2007).

Tal crise ou transição de valores tem suas raízes em contradições da modernidade, principalmente no que diz respeito à aparente efemeridade e relatividade em todos os âmbitos da vida. Essa aparente indefinição de valores mascara a ordem e o despotismo do mercado que necessita de homens livres para vender sua força de trabalho e propõe a realização individual que, por sua vez, não pode ser alcançada por todos no atual contexto neoliberal de acirramento das desigualdades, perda de direitos sociais e competitividade (Soares, 2007).

Partindo do trabalho de João Bernardo (2000), Soares (2007) afirma que os valores econômicos dominantes ao se propagar pela vida social expressam a 
necessidade do capital de se reproduzir e formar a cultura institucional acarretando diferentes impactos sobre os jovens das diversas classes sociais. Tais valores econômicos influenciam a constituição de valores sociais que por sua vez podem refletir tanto a resignação quanto a subversão da ordem social. O consumo de drogas pelo jovem na contemporaneidade pode estar relacionado a esses valores sociais.

Nessa perspectiva o projeto matriz objetivou sistematizar um arcabouço teórico-metodológico e operacional para intervenção junto a jovens, baseado nos valores sociais e relativos ao consumo de drogas em diferentes classes sociais, sob o ponto de vista da Saúde Coletiva, com a finalidade de alicerçar o desenvolvimento de políticas públicas de prevenção na área.

Assim, entre os objetivos do projeto estavam: a) caracterizar os jovens sujeitos de pesquisa segundo a classe social; b) investigar os valores sociais que estruturam a relação dos jovens com a realidade contemporânea e os valores que encorajam/desencorajam o consumo de drogas entre jovens de diferentes classes sociais, d) analisar as diferenças entre os diversos valores expressos pelos jovens nas diferentes classes sociais; g) aperfeiçoar um esquema teórico-metodológico e operacional disponibilizando-o para as instituições que trabalham com jovens de diferentes classes sociais, com vistas à prevenção do consumo prejudicial de drogas.

Esses objetivos vêm apoiar a necessidade evidenciada na literatura epidemiológica - de que trataremos nesta tese mais adiante - de se aprofundar a discussão sobre as classes sociais na atualidade, especialmente, no que diz respeito ao equacionamento das variáveis, ou conjunto de varáveis que discriminem grupos sociais na contemporaneidade para o alcance dos objetivos do estudo matriz.

Nesse sentido deriva o presente estudo que foi sendo formulado diante das dificuldades apresentadas para definição de classes sociais no âmbito da Epidemiologia Crítica, tendo como horizonte aperfeiçoar instrumentos de captação de variáveis que possam ser utilizadas para captar diferenças entre grupos sociais. 
1. INTRODUÇÃO 


\section{1- Introdução}

\subsection{Relação entre inserção social e processo saúde-doença: perspectiva da Epidemiologia Crítica.}

O desenvolvimento de ações voltadas ao controle de saúde da população acompanhou a redefinição progressiva da medicina como prática social com o advento do capitalismo no final do século XVIII. Sua incorporação se identifica assim com o processo mais geral que reorganiza os elementos da vida social na constituição da estrutura de produção capitalista. Até então, a medicina era a prática dominante em saúde voltada primordialmente ao atendimento do corpo individual (Donnangelo, Pereira, 1979).

A necessidade de atender ao processo de acumulação capitalista levou o Estado a disciplinar a medicina de modo que esta se tornasse instrumento de controle sobre a vida social. O Estado capitalista, instaurado para responder às exigências do capital, voltou sua atenção para a vigilância das condições de saúde das populações, guiado pelo interesse no controle e na reprodução da força de trabalho, absolutamente necessária para garantir o processo de acumulação original do capital. Assim a medicina abraçou a causa das medidas de controle do ambiente e das populações urbanas (Donnangelo, Pereira, 1979).

Nessa perspectiva, a Saúde Pública forjou seu projeto no contexto do projeto liberal privatista e a Epidemiologia Clássica forneceu o instrumental epidemiológico para a operacionalização desses objetivos (Mendes-Gonçalves, 1990).

Ressalta-se nesse processo o papel da Medicina Preventiva, que se construiu primeiramente na Inglaterra e depois no Canadá e Estados Unidos, como estratégia de formação do médico liberal que se aproximasse da comunidade e se relacionasse com os serviços públicos de saúde, com a promoção e a proteção da saúde do indivíduo e de sua família (Arouca, 1975).

O discurso preventivista, após o seu desenvolvimento nos países centrais se expandiu para a América Latina, baseando-se na História Natural das Doenças, assumindo a multicausalidade e o afastamento das determinações sociais do processo saúde-doença. "O movimento preventivista possuía assim uma baixa densidade política ao não realizar modificações nas relações sociais concretas e uma alta densidade 
ideológica ao constituir, através do seu discurso, uma construção teórico-ideológica daquelas relações" (Arouca, 1975: 179). E a Epidemiologia, nesse referencial, abriu espaço para captar um social naturalizado e atomizado, homogêneo em substância, heterogêneo em quantidade e desprovido de historicidade (Mendes-Gonçalves, 1990).

Por outro lado, ao introduzir nas escolas médicas uma discussão sobre a Teoria da Medicina, a Medicina Preventiva possibilitou o aparecimento de núcleos de reflexão que se constituíram em um novo campo da Prática Teórica (Arouca, 1975)

Assim, acabou-se por abrir espaço também para que outras vertentes conceituais apresentassem suas formas de compreensão e ação sobre a dimensão social do processo saúde-doença.

Essas outras formas de conceituação embasaram, especialmente nos países do chamado Terceiro Mundo e particularmente na América Latina, núcleos de resistência comprometidos com a superação das desigualdades sociais e em saúde, que questionavam a forma como a sociedade capitalista se estrutura e diferencia as pessoas em grupos ou classes sociais, com acesso distinto ao trabalho e aos bens de consumo (Laurell, 1983; Granda, Breilh 1991 ).

Para além da compreensão teórica, esses núcleos buscavam agir para mudar essa realidade, o que se expressou nas lutas pela transformação das grandes disparidades sociais e das distorções decorrentes do capitalismo dependente na década de 60. Tais lutas estiveram sobretudo localizadas na esfera do trabalho e dos movimentos sindicais que, no âmbito da saúde, deram origem ao campo da Saúde do Trabalhador (Laurell, 1983).

No campo da Saúde do Trabalhador surgiram, sob a liderança da Profa. Asa Cristina Laurell da Universidade Autônoma do México, os primeiros estudos que impulsionaram a constituição do novo conhecimento epidemiológico, a Epidemiologia Social, designada de Epidemiologia Crítica pelo Prof. Jaime Breilh do Centro de Estudos e Assessoria em Saúde do Equador (Granda, Breilh 1991).

O campo da Epidemiologia Crítica contesta as limitações da Epidemiologia Tradicional no que diz respeito à sua inadequação para explicar os determinantes do processo saúde-doença, ao analisar a distribuição da doença como resultado do desequilíbrio entre agente, meio e hospedeiro e sua manifestação através de 
associações estatísticas, que tomam o meio como mais um fator, compreendido como um fator natural. A Epidemiologia Tradicional, no melhor dos casos, considera de maneira insuficiente - podendo conduzir a distorções da realidade - as relações entre a inserção produtiva dos sujeitos, das diferentes classes sociais, e os resultados do processo saúde doença e pauta-se no empirismo ao desarticular as ações (prática) de uma determinada visão de mundo e da realidade social (teoria) (Granda, Breilh, 1991).

A Epidemiologia Crítica compõe o arcabouço teórico-metodológico que fundamenta as investigações embasando-se nos conceitos de espaço geossocial, classe social e história, em substituição aos conceitos positivistas de lugar, pessoa e tempo da Epidemiologia Tradicional. Fundamenta-se numa compreensão de saúde e doença que coloca no centro da explicação dos determinantes da saúde, o trabalho a produção capitalista - e, a ele subordinado, a vida - o consumo sob o comando do processo de acumulação capitalista. Nessa perspectiva o objeto de intervenção se configura, conforme Granda e Breilh (1991), nos perfis epidemiológicos das classes sociais que se constituem sob o modo de produção capitalista num determinado espaço geossocial, o resultado da conjunção entre os perfis de reprodução social (determinantes do processo saúde-doença) e os perfis de fortalecimento e de desgaste (resultados do processo saúde-doença). Cabe destacar que entre o trabalho e a vida, uma rede hierarquizada de determinação estrutura o fortalecimento e o desgaste do corpo biológico (Granda, Breilh, 1991).

Nessa perspectiva, Krieger, Williams e Moss (1997) sistematizam a importância do estudo das desigualdades sociais na área da saúde em três pontos, conforme nos ensinou Yonekura (2011):

a) A forte relação entre posição socioeconômica e mortalidade e morbidade. Diversos estudos enfatizam a relação entre as condições de vida e de trabalho e os índices de mortalidade adulta e infantil, doenças crônicas, infecciosas e psiquiátricas.

b) A crescente desigualdade de renda e riqueza internacional acompanhadas das desigualdades socioeconômicas em saúde.

c) A relação inversa entre as taxas de mortalidade e os indicadores de desigualdade social em saúde. Mesmo com o declínio das taxas de mortalidade, as desigualdades socioeconômicas em saúde nos países industrializados continuam aumentando. 
O mesmo estudo sugere três recomendações para novas investigações (Krieger, Williams, Moss, 1997):

a) são necessárias investigações para identificar como a relação indivíduo, família, bairro, classe social e outros aspectos da inserção social se relacionam entre si e se combinam para afetar a saúde.

b) os estudos devem focar na dimensão histórica da inserção social, já que a pobreza adquire características peculiares ao longo do tempo, e analisar as suas conseqüências para a saúde.

c) a pesquisa deve investigar outros aspectos da inserção social e o impacto na saúde, como a classe social do indivíduo na infância.

A partir dessas considerações e com apoio no trabalho de Yonekura (2011) que realizou extensa e aprofundada análise de estudos empíricos que correlacionam classe social com diferentes desfechos do processo saúde-doença, considera-se que trabalhar com o conceito de classes sociais e sua operacionalização é imprescindível nos estudos epidemiológicos que objetivam fornecer arcabouço teórico-metodológico e instrumentos para a transformação do processo saúde-doença do coletivo, mesmo porque na perspectiva da Saúde Coletiva a intervenção, ainda que dirigida mais particularmente a indivíduos, deve considerá-los sempre em referência à classe social a qual pertencem (Lacaz, 2001).

Concordando com tais afirmações, neste trabalho se apresentará a seguir um conjunto de considerações teóricas que mobilizam o debate em torno do conceito de classe social. 
2. CONSIDERAÇÕES TEÓRICAS 


\section{2 - Classes sociais: considerações teóricas}

Diante das mudanças políticas e econômicas das últimas duas décadas em que o capitalismo industrial foi sendo substituído pelo capitalismo financeiro em um contexto de globalização, diversos teóricos consideram a insuficiência de se utilizar a categoria classe social nos atuais estudos sociológicos (Crompton, 1998; Antunes, 2000; Mattos, 2006). Entretanto, ressaltam que mesmo que a classificação da inserção social dos sujeitos no processo produtivo não possa se reduzir às condições polarizadas de burguesia e proletariado, não se pode negar que ainda existam iniqüidades e relações de dominação entre os que exploram e os que são explorados em diferentes gradientes. O próprio incremento das iniqüidades e desigualdades sociais se configura em estratégia para acirrar a competição e o individualismo característicos do Estado neoliberal (Antunes, 2000). Ressaltam também que é necessário ter clareza da persistência das iniqüidades materiais entre as classes a despeito dos argumentos dos pós-modernos que defendem as modernas teorias de mudança da sociedade. Mesmo diante do aumento da importância do consumo, do status e dos estilos de vida na estruturação da sociedade não se pode negar o papel fundamental da dimensão econômica na estruturação e persistência dos sistemas de iniqüidade social (Crompton, 1998).

Assim, no lugar de se afirmar a perda da validade analítica da noção de classe, coloca-se a necessidades de atribuir contemporaneidade e amplitude à classe trabalhadora hoje, sem perder de vista as relações de exploração presentes no atual processo de reestruturação produtiva (Mattos 2006; Antunes, 2000). Segundo Mattos (2006):

(...) a velha divisão entre exploradores e explorados está longe de ter sido superada. Pelo contrário, a nova diversidade da classe trabalhadora (com diferenças entre trabalho formal e informal, precário, terceirizado, eventual, diferenças de gênero, etc) não pode ser compreendida senão no marco da luta de classes (Mattos, 2006, p. 5).

Nessa perspectiva, Crompton (1998), ao introduzir debates sobre classe e estratificação social, discute as limitações de se trabalhar com classificações a partir de ocupações e do conjunto de empregos, pois essas são medidas que não consideram as iniqüidades sociais no âmbito da participação na riqueza. Questiona 
também o fato de que a metodologia de análise de classe a partir do conjunto de empregos não deixa clara a ligação entre classe, consciência de classe e ação social. Mesmo diante de tantas críticas, a autora afirma que tais argumentações não bastam para decretar a morte das classes e que as classificações por tipo de emprego continuam sendo importantes como indicadores sociais.

Nesse sentido, as metodologias de análise de classe também devem considerar o processo de formação das classes.

No referencial marxista, tal formação está diretamente ligada ao processo de produção capitalista sendo que as relações de classe são baseadas em exploração e dominação inerentes às relações de produção com a finalidade da extração da maisvalia. Marx afirmava que a ação de classe era inevitável e que os conflitos de classe representavam a possibilidade de transformação da estrutura social (Marx, 2008; Galobardes, Lynch, Smith, 2007; Viana, 2007; Mattos, 2006; Crompton, 1998).

Já no referencial de Weber, a classe social define a situação econômica de um indivíduo na sociedade por meio da sua relação com o mercado, o que ele pode ou não pode comprar. Os indivíduos pertencem à mesma classe, quando por exemplo, a posse de mercadorias os coloca em uma posição semelhante, e, é essa situação que lhes possibilita poder e prestígio (Crompton, 1998; Galobardes, Lynch e Smith 2007; Marks, 1999)

$\mathrm{Na}$ construção do conceito de classes sociais na contemporaneidade outras questões têm sido incluídas como o significado do status, o senso de consciência das comunidades e categorias de estilos de vida (Crompton, 1998, Marks, 1999). Autores como Bourdieu (2008) enfatizam o crescimento do significado da cultura e das práticas de consumo para compreender as identidades e comportamentos das sociedades contemporâneas. Bourdieu não define classe por meio das diferentes relações com os meios de produção, mas por diferentes condições de existência e de acesso ao poder ou capital (capital econômico, social, cultural ou simbólico), que constituem elementos que instrumentalizam os sujeitos para os conflitos e disputas por posições no espaço social.

Crompton (1998) chama a atenção para o debate entre os que acreditam que a cultura e os estilos de vida (status) se tornam mais significantes na formação das classes e entre aqueles que defendem a determinação econômica como elemento estruturante. Entretanto, a autora afirma que, mesmo diante do aumento do 
significado do consumo, do status e dos estilos de vida na conformação da sociedade não se pode negar o papel primordial da dimensão econômica na estruturação e persistência dos sistemas de iniqüidade social.

Deve-se considerar que uma única aproximação não consegue incorporar todos os elementos do debate a respeito de classe e estratificação, pois as teorias em questão fornecem não somente diferentes versões da mesma realidade, mas também focam diferentes aspectos do todo. Não se pode negar a persistência das iniqüidades materiais entre as classes a despeito dos argumentos dos pós-modernos que defendem as modernas teorias de mudança da sociedade. Por outro lado não é possível desconsiderar as colocações dos pós-modernos sobre as mudanças atuais da natureza do trabalho e de suas características anteriores de organização coletiva e de conflitos entre identidades diante da atual fragmentação e desarticulação da classe trabalhadora.

Serão apresentados a seguir os conceitos e teorias a respeito de classes sociais a partir de trabalhos de Marx, Weber, Thompson e Bourdieu segundo as três dimensões possíveis de sua abordagem, conforme Crompton (1998). Ressalta-se que a intenção não é restringir os trabalhos de autores clássicos a uma mera classificação, mas identificar sobre qual âmbito (estrutura econômica, status/estilo de vida, ação social) estrutura-se o eixo norteador dos trabalhos em questão.

\section{1 - Classe social a partir dos trabalhos de Marx, Weber, Thompson e Bourdieu}

\subsection{1 - Classe social no âmbito da estrutura econômica - referencial marxista}

Num sentido mais amplo, que denota desigualdade, a estratificação em classes é reconhecida historicamente desde a Grécia antiga definida pela propriedade ou não de terras. Porém, a partir da constituição das sociedades industriais capitalistas, forja-se por meio de novas formas de produção mercantis uma nova classe, a burguesa, que concentra em suas mãos a propriedade dos meios de 
produção. Ela investe capital para valorizá-lo mediante a extração de um sobretrabalho não pago aos trabalhadores assalariados livres, sem qualquer vínculo tradicional com seus patrões ou com a terra e demais meios de produção. Esses trabalhadores vêem-se obrigados a vender sua força de trabalho para sobreviver, e só constituem-se propriamente como classe quando se associam para lutar contra a exploração a que são submetidos. Nesse sentido específico apareceriam as classes n’O Capital (Ridenti, 1994).

Assim, conforme afirma o professor Nildo Viana, a respeito do conceito de classes sociais em Marx, a classe não é uma mera classificação baseada em uma determinada característica como faixa de renda, mas sim parte da realidade do "processos histórico do engendramento das classes, seu desenvolvimento e tendência para superação, nas relações sociais concretas no processo da história da humanidade" 2 .

Dessa forma, compreender classes sociais em Marx implica em trabalhar com outros elementos que completam a análise da realidade social e assim tornam-se fundamentais os conceitos de modo de produção, divisão social do trabalho, mais valor, acumulação do capital, entre outros ${ }^{3}$.

Marx (1996) discute classe sob o ponto de vista sistêmico do processo de produção capitalista, trabalhando com a distinção entre forma - troca e venda de mercadorias, e conteúdo - exploração capitalista. Nos capítulos XXI, XXII, XXIII d'O Capital na seção que trata do processo de acumulação do capital ele foca as relações elementares do sistema de produção e identifica os mecanismos de exploração econômica entre as classes. A classe assim configura-se na personificação da relação capital- trabalho.

Viana $^{4}$ afirma que para Marx classe social e divisão do trabalho estão intrinsecamente relacionadas, sendo a divisão do trabalho determinada pela posse da propriedade privada. Dessa forma, as relações de classe são relações de propriedade. A divisão social do trabalho é a chave para explicar a exploração revelando o domínio sobre a força de trabalho e a repartição desigual do trabalho e de seus produtos. Nesse sentido classes sociais se conformaram a partir da instituição da propriedade privada, mesmo nas sociedades pré-capitalistas. O que diferencia as

\footnotetext{
${ }^{2}$ Viana N. A teoria das Classes Sociais em Karl Marx, 2011; p10.

${ }^{3}$ Idem, ibidem

${ }^{4}$ Idem, ibidem
} 
sociedades pré-capitalistas das contemporâneas são as formas de exploração e o antagonismo gerado por elas.

A relação de exploração entre os detentores dos meios de produção e o proletariado é explicada por meio do processo de acumulação do capital a partir da reprodução simples e da transformação da mais-valia em capital (Marx, 1996).

A reprodução simples ocorre quando a mais-valia serve ao capitalista apenas como fundo de consumo ou é despendida com a mesma periodicidade com que é ganha permanecendo constantes as demais circunstâncias. Mesmo que nesse processo não ocorra acumulação de capital a exploração está presente já que o proletariado produz, além de seu próprio fundo de pagamento, o fundo de consumo do capitalista. Ou seja, o trabalhador não recebe o correspondente ao seu dispêndio de energia e é obrigado a vender sua força de trabalho para viver enriquecendo o capitalista que a compra. Outro ponto a ser considerado é o fato de que o capitalista não lucra apenas com o que recebe do trabalhador, mas também com o que lhe dá, já que o próprio consumo individual da classe trabalhadora consiste em retransformação dos meios de subsistência em força de trabalho novamente explorável pelo capital. A classe trabalhadora é, mesmo fora do processo direto de produção, um acessório do capital, do mesmo modo que o instrumento morto de trabalho (Marx, 1996).

Quando se considera o outro processo de acumulação capitalista transformação da mais-valia em capital - a exploração da classe trabalhadora aumenta de escala. Para criar mais-valia de modo que possa ser acumulada em capital, o mais-produto já deve conter em seus componentes materiais um novo capital e para tanto a exploração do trabalhador deve ser maior, quer seja por meio da redução de salários ou por aumento da jornada de trabalho (Marx, 1996).

O próprio mecanismo do processo de acumulação multiplica, com o capital, a massa dos assalariados, que transformam sua massa de trabalho em crescente força de valorização do capital perpetuando assim sua relação de dependência para com seu próprio produto e por consequência, para com o capitalista. Com o aumento da produtividade por meio do aperfeiçoamento técnico passa a ocorrer um investimento maior nos meios de produção (capital constante) em detrimento da força de trabalho (capital variável) já que uma massa menor de trabalho se torna necessária para se colocar em funcionamento a maquinaria. Assim, com a diminuição da demanda por 
força de trabalho, forma-se um exército de reserva disponível para ser lançado nos pontos decisivos sem quebra da produção. Dessa forma não é o trabalhador quem emprega os meios de trabalho e sim os meios de trabalho que empregam o trabalhador. Assim todos os meios para o desenvolvimento da produção mutilam o trabalhador, tornando-o um ser parcial e apêndice da máquina. Dessa forma, todos os métodos de produção de mais-valia são métodos de acumulação e à medida que se acumula capital a situação do trabalhador tende a piorar, ou seja, a acumulação da riqueza num pólo é, portanto acumulação da miséria da classe trabalhadora (Marx, 1996).

O sistema capitalista produz o operário como proletariado o que implica em contradição, pois o sujeito é aparentemente livre, mas deve se assalariar para sobreviver no sistema, ou seja, ao mesmo tempo em que existe liberdade individual, existe escravidão societária. Essa situação se mostra igualitária na aparência, pois o capitalista troca salário por trabalho, mas o que ocorre é exploração. O próprio exército de reserva assegura o controle capitalista, pois mantém os salários baixos e a produtividade garantindo a taxa de exploração intrínseca à relação capitalistatrabalhador.

As relações de exploração entre grupos humanos para apropriação do excedente gerado além do mínimo necessário para subsistência resultam em lutas de classe segundo Marx, que por sua vez representavam a possibilidade de transformação da estrutura social (Galobardes, Lynch, Smith, 2007; Viana 2007, Crompton, 1998).

A análise marxista do capitalismo prevê a possibilidade objetiva da transformação desse modo de produção pela ação revolucionária da classe trabalhadora, mas o percurso de constituição da classe, incluindo a construção de sua consciência, não é previsível cientificamente, dependendo da organização e da luta dos próprios trabalhadores ao longo do tempo (Ridenti, 1994).

N'O Capital a sociabilidade proletária não recebe destaque, nem sua ideologia, pois não há o foco na luta entre classes. Elas ficam mais claras em outro trabalho de Marx, o 18 Brumário que "demonstra como a luta de classes na França criou circunstâncias e condições que possibilitaram a um personagem medíocre e grotesco [Luís Bonaparte no período de 1848 a 1851] desempenhar um papel de herói" (Marx, 2008: 14). 
N'O 18 Brumário a inserção econômica foi o ponto de partida para se discutir o aspecto de transformação política por meio do conceito de classe pensado como ator coletivo.

Ressalta-se, entretanto, que não houve lutas de classe em seu sentido estrito. Isso porque n'O 18 Brumário as classes não eram polarizadas e as lutas se davam entre coalizões e não entre classes, sendo que cada coalizão podia agregar certas classes em detrimento de outras (grande burguesia, burguesia, pequena burguesia, aristocracia financeira, grandes proprietários, camponeses, proletariado e lumpemproletariado). Os conflitos ocorreram no âmbito da discussão política e não da estrutura econômica. Uma das razões para isso seria a de que a Revolução Industrial teve um desenvolvimento débil na França, a maioria da população francesa era camponesa e tanto a industrialização quanto a formação do proletariado foram incipientes.

Marx identificou n’O 18 Brumário um processo de transformação frustrado já que não houve um processo de constituição de classe como força política própria. As coalizões envolvidas colocaram o processo de transformação da situação centralizado nas mãos de Bonaparte.

Rident (1994) afirma que para Marx a luta de classes dependeria da construção de consciência de classe e se configura em movimento da sociedade centrado nas classes. A luta não pode ser literalmente trazida de fora da classe em si, por partidos ou intelectuais que supostamente tenham o domínio das leis da história, ela deve brotar de dentro da própria classe, de sua práxis. Por isso os assalariados, proprietários de terra e capitalistas são construtores de sua própria classe. Quando Marx atribuiu um papel revolucionário aos trabalhadores, mostrava que dada a constituição do capitalismo estava posta a possibilidade objetiva de que o conjunto de trabalhadores livres e iguais se constituíssem em classe e rompessem com a exploração de uma classe por outra, mesmo que num dado momento eles não tivessem consciência de que sua ação poderia revolucionar o mundo. Os rumos a serem tomados pelos processos de construção da classe para si dependeriam da dinâmica da luta de classes. As análises de Marx apontavam para a potencialidade de uma consciência operária revolucionária. A possibilidade dessa consciência, de tornar-se plena só no final de um processo tortuoso de constituição de classe em si e 
para si foi atribuída por Marx à classe operária, não como algo ideal, mas a partir de uma análise exaustiva do capitalismo e das lutas de classe de seu tempo.

\subsection{2- Classe social no âmbito do status e estilo de vida- Weber e Bourdieu}

A questão da inserção econômica e do potencial da luta de classe como transformador da realidade não é central no trabalho de Weber como ocorre na obra de Marx.

Para Weber, em seu trabalho Economia e Sociedade, a ação coletiva é vista como uma possibilidade, mas não é imprescindível, sendo que ela pode ocorrer como ação de massa, mas não necessariamente como ação coletiva. $O$ mandato revolucionário não está presente na teoria de Weber como está na de Marx. O autor considerava que as classes representavam apenas a possibilidade para a ação comum e não via nos conflitos de classe a possibilidade de mudança (Weber, 1999).

Para o autor, classe não é de imediato uma coletividade, mas sim um conjunto de pessoas com semelhantes posições no mercado. Existiria um destino proletário e um destino do capitalista e a base da ação seria a disputa.

Dessa forma a "situação de classe" significa "situação de mercado". Assim, a relação entre as classes ocorre quando sujeitos que possuem bens e propriedades estabelecem relações de troca com sujeitos que podem oferecer apenas seus serviços em forma de trabalho ou produtos do seu próprio trabalho (Weber, 1999).

Tal referencial influenciou diversos teóricos contemporâneos, entre eles Goldthorpe, que propôs um esquema de classificação em classes sociais que, além de considerar o tipo de ocupação, inclui fontes e níveis de renda, seguridade econômica, possibilidades de desenvolvimento econômico, posição do trabalhador dentro de sistemas de autoridade e controle do processo de produção no qual está engajado (Crompton, 1998; Marks, 1999).

Para Weber, a classe não é a única forma de organização da sociedade. Seu trabalho contempla o conceito de comunidade que pode ter um caráter de classe definida pela ordem econômica, ou de estamento definida pela ordem social (Weber, 1999). As classes estão relacionadas às oportunidades de vida e à posse de bens e 
propriedades, sendo determinadas pelas oportunidades de mercado. Os estamentos estão relacionados à forma como se conduz a vida sendo esta determinada pela honra, prestígio, dignidade, seletividade, distanciamento e exclusividade.

Os dois últimos são elementos centrais na conformação dos estamentos: distanciamento de certos estamentos em relação aos outros definidos segundo posição de classe, qualificação pessoal e prestígio; e exclusividade em relação ao monopólio de posse de bens.

Verifica-se também que a luta de classes ocorre em âmbito diverso do considerado por Marx. Para Weber, os agentes estão em luta devido ao fato de que os bens materiais (dinheiro, mercadoria) e ideais (honra, prestígio) são escassos, sendo que a lógica de ação dos agentes é pautada no conflito, mas não necessariamente se realiza na ação de classe.

O mundo de Weber é um mundo de escassez: se disputam bens, honra, graças divinas. Ressalta-se também que a propriedade ou não propriedade é salvaguardada por uma ordem jurídica e essa propriedade faz determinada classe se conformar à outra. A posse de bens se configura em meio pelo qual um conjunto de agentes força a outra classe a trocar sua mercadoria de certa forma. Assim, o poder envolve uma relação de conformação de outro por aquele que domina. Nessa relação, o dominado acaba tomando para si a ordem do outro como se partisse dele (Weber, 1999).

A dominação estabiliza as ações sociais, pois arrefece as disputas que poderiam romper as relações na sociedade. A luta, nessa perspectiva deixa de se configurar em rompimento a passa a assumir caráter de competição (luta pacífica).

Verifica-se assim que enquanto para Marx o conceito-chave de relação entre as classes é a exploração para obtenção da mais-valia, para Weber é a relação de dominação entre classes e principalmente entre estamentos.

Para Weber a conduta de vida e os estilos de vida definidoras do estamento apresentam destaque em relação à classe social, havendo tensão entre classe e estamento. Essa tensão não existe em Bourdieu que incorpora elementos de classe e estamento de Weber em sua construção do conceito de classe social, relacionando macroeconomia, microeconomia e as escolhas dos diferentes grupos sociais.

A partir do trabalho A distinção: crítica social do julgamento fica clara a influência weberiana no trabalho de Bourdieu (2008), bem como suas diferenças em relação ao referencial marxista. O referencial de Bourdieu já se distancia de Marx no 
primeiro parágrafo ao definir homem: enquanto para Marx o homem se afirma na transformação da natureza por meio do trabalho, para Bourdieu "o julgamento do gosto é a manifestação suprema do discernimento que (...) define o homem na acepção plena do termo" (2008:17). Sendo que o discernimento está relacionado ao capital cultural que por sua vez possibilita diferentes condições de relação entre as classes mediadas pelo mercado.

Outro ponto que caracteriza o trabalho de Bourdieu (2008) como weberiano seria o caráter da relação entre as classes. Para Bourdieu assim como para Weber, a luta de classes se dá por meio de uma relação de dominação a depender da inserção dos grupos antagonistas no mercado (no caso de Bourdieu as lutas se constituem em um jogo entre campos de forças), diferente de Marx em que a luta de classes se dá como resposta às relações de exploração presentes no processo de produção capitalista.

Nesse sentido, segundo Bourdieu, as classes são definidas segundo o capital cultural - relacionado em certa medida ao capital escolar assegurado socialmente pelo diploma - que influenciam os gostos, as escolhas e os estilos de vida das diferentes classes, principalmente no que diz respeito à arte (música e pintura), ressaltando que o capital cultural varia conforme a sociedade, o país e o período histórico. Ao discutir o que distingue as classes sociais, Bourdieu afirma que as representações sociais são elementos que as definem, ou seja, a maneira como cada uma das frações de classe percebe a música e a pintura, por exemplo.

Ressalta-se que o autor supõe que há homogeneidade do capital cultural no qual existe um mesmo padrão cultural e um mesmo sistema simbólico: o proletariado não consome champagne, mas bebe sidra que é mais acessível e também é consumida para comemorar ocasiões especiais. O que vale para as classes dominantes vale para as outras só que as mais excluídas economicamente não conseguem ter o mesmo acesso.

Bourdieu trabalha com a idéia de que o capital cultural (que se configura em elemento constituinte do habitus) pode se conformar em instrumento de dominação de uma classe ou frações de classes em sociedades nas quais a herança cultural não é distribuída de forma equitativa. Nessa perspectiva, o autor trabalha o tempo todo com a relação entre os campos de produção em que se elaboram produtos e os campos em que se determinam os gostos. Os campos de produção tanto existem para 
atender os gostos já construídos quanto para criar novas necessidades e novos gostos, realimentando assim o sistema.

$\mathrm{O}$ autor discute também a relação entre a capacidade de distinção definida pelo capital cultural e o conjunto de práticas que definem as classes. Reafirma que essas classes não são definidas somente por categorias socioprofissionais, propriedades ou posição nas relações de produção, mas pela estrutura de relações entre todas as propriedades pertinentes e os efeitos que elas exercem sobre as práticas reafirmando a influência weberiana do autor.

Um ponto importante abordado por Bourdieu diz respeito às possibilidades de deslocamentos dentro das classes (vertical) e entre as classes (transversal). O autor faz essa análise tendo por pano de fundo o capital cultural em seu componente educacional.

Bourdieu afirma que a rápida propagação da escolaridade entre as classes levou a uma concorrência por diplomas ao mesmo tempo em que causou uma desvalorização desses documentos acabando por prejudicar justamente as classes populares já que a expansão do número de certificados atingiu inclusive postos de trabalho que antes não os exigiam. Com a propagação dos diplomas e sua conseqüente desvalorização as aquisições destes deixaram de ser uma garantia de ascensão para classes populares, levando a uma "desilusão coletiva que predispõe essa geração enganada e desiludida a estender, à todas as instituições, a revolta mesclada de ressentimento que lhe inspira o sistema escolar" (2008: 136). Nessa perspectiva, uma questão estrutural acaba sendo abarcada pelos indivíduos das classes populares que se sentem incapazes e assim, passa-se do terreno da crise social para o terreno da crise pessoal.

Nesse trabalho o autor também discute a conformação do espaço dos estilos de vida. Bourdieu defende que esse espaço é constituído pela capacidade dos diferentes grupos sociais de produzirem, classificarem e apreciarem as práticas, constituindo-se assim, habitus distintos. Nessa perspectiva, as classes sociais têm diferentes estilos de vida decorrentes de opções e gostos (práticas), que por sua vez dependem das disposições desses grupos no espaço (habitus) influenciadas pelas posições relativas dos agentes das práticas. Bourdieu ressalta que as escolhas e práticas não são determinadas apenas por questões econômicas, já que mesmo que 
ocorra uma melhora dessas condições, os indivíduos podem continuar a ter um "gosto popular".

Em resumo, no espaço social estão dispostas as posições relativas dos agentes das práticas (posições essas que dependem do capital social, econômico e cultural). As posições relativas produzem disposições não conscientes (habitus) que por sua vez produzem opções (práticas, gosto). As opções objetivam-se em distinção e pretensão de se alcançar determinada posição e satisfazer necessidades.

Nos capítulos finais, Bourdieu aborda a pequena burguesia e o faz por meio da relação desta com a cultura legítima. Afirma que essa fração de classe busca se dedicar a um culto irrefletido à essa cultura em um processo de falsa identificação que faz com que escolhas desconexas sejam feitas, como por exemplo, assistir tanto programas culturais quanto programas de variedades. $O$ autor apresenta as características de desconexão, falta de solidariedade e de identidade dessa fração de classe que se configura em um proletariado que se "faz pequeno para se tornar burguês".

Grande parte dessas contradições advém de um baixo capital cultural acumulado devido principalmente a uma cultura escolar limitada. Diante da necessidade de suprir a falta de capital econômico e/ou cultural e ascender à burguesia e a tudo que se relaciona com o "gosto legítimo", os pequeno-burgueses se colocam restrições como diminuição de despesas, controle de natalidade e renúncias. Pobre, assim, em capital social, cultural e econômico, "a pequena-burguesia só pode justificar suas pretensões por meio da virtude" (2008: 316). Como a pequena burguesia deve se concentrar em reduzir despesas e contar com os próprios esforços, somente pode contar consigo mesma reduzindo assim os laços de solidariedade. As relações sociais deixam de ser um apoio para o pequeno-burguês (como ocorre com o proletariado) e passam a significar entraves para a ascensão à burguesia (Bourdieu, 2008).

A pequena burguesia se coloca entre a necessidade do proletariado e a distinção da burguesia. Enquanto o conhecimento é buscado pela burguesia, a pequena burguesia realiza o reconhecimento ("se algo é utilizado ou consumido pela burguesia, então deve ser muito bom") caracterizando-se pela pretensão de ascender. 
O autor também aborda as classes populares por meio da análise da escolha que estas fazem pelo necessário já que estão submetidas à privação de bens materiais que as fazem escolher justamente o necessário para subsistência.

As classes populares não têm base material suficiente para poderem se afastar dessa base e olhar para a arte se distanciando e apreciando. Essa submissão à necessidade leva a uma estética pragmática e funcionalista (2008: 353). Nessa perspectiva o autor aborda os efeitos da dominação sobre as escolhas das classes populares em que uma posição dominada implica uma forma de aceitação da dominação, inclusive em relação ao que é ou não "gosto legítimo".

Nessa perspectiva, para o autor o propósito das lutas no mundo social é estabelecer o poder sobre os esquemas classificatórios e os sistemas de classificação que se encontram na origem das representações, por conseguinte, da mobilização e desmobilização dos grupos.

Para Bourdieu, a luta é mais simbólica do que para Weber em que há disputas pela propriedade de bens e por prestígio. Essa luta consistiria em uma luta "surda" pela classificação e escolhas, não necessariamente atingindo o espaço político.

\subsection{3- Classe como ação social - Thompson}

Se para Bourdieu e Weber a mobilização dos grupos para a luta não se constitui propriamente em elemento definidor de classes sociais, para Thompson essa mobilização apresenta papel importante no processo de formação de classe e é no espaço público que ela se mostra.

Em seu trabalho A formação da classe operária inglesa o autor apresenta no primeiro volume as transformações políticas e econômicas desencadeadas pelo nascimento da indústria e desenvolvimento do modo de produção capitalista tendo como eixo a ação social do "povo da Revolução Industrial” (Thompson, 1987: 13), bem como a resposta reacionária dos detentores de propriedades e dos meios de produção durante o processo de efervescência da Revolução Industrial entre 1780 e 1832.

Apresenta líderes dos movimentos como Thomas Hardy fundador da Sociedade Londrina de Correspondência e Tom Paine que escreveu Direitos do 
Homem ("há duas classes distintas de homens na nação, a dos que pagam impostos e a dos que recebem e vivem dos impostos”) (Thompson, 1987: 100). Apresenta também a reação a esses movimentos, reação essa que se pautou no direito de defesa da propriedade e recorreu à religião metodista para aplacar tais movimentos.

Para Thompson todo o peso da abordagem das classes está na livre disposição dos homens para agir numa dada situação histórica. A relevância da visão de Thompson sobre o tema das classes sociais está em não tomá-las como coisa e em questionar as diferentes concepções que poderiam ser denominadas mecanicistas, marxistas-positivistas ou estruturalistas (Ridenti, 1994).

Nessa perspectiva, Thompson vê a classe como fenômeno histórico, não como uma estrutura, mas como algo que ocorre efetivamente nas relações humanas (Ridenti, 1994). Como é um processo não há rupturas inesperadas. A questão não é econômica e sim um processo político. A Revolução Industrial em si não foi a responsável por formar a classe operária para Thompson, ela forneceu a base material para que a formação se processasse. Sendo assim, verifica-se que o autor não trabalha com o conceito de reprodução social.

Ridenti (1994), ao analisar o trabalho de Thompson, afirma que o autor valoriza a luta de classes para a compreensão da história e a crítica que ele faz aos marxistas estruturalistas seria a de que para eles não existe teoricamente uma ponte que ligue as questões estruturais aos processos históricos. Para eles, segundo Thompson, as classes existem, independentemente de relacionamento histórico e de luta, ao invés de virem a existir daquela luta. Por outro lado, Thompson esclarece não supor a formação de classe como independente de determinações, definida simplesmente como formação cultural. Entretanto, para ele essas determinações objetivas requerem o exame mais escrupuloso (Ridenti, 1994).

Thompson nega qualquer modelo para estabelecer como devem ser as classes mostrando que elas se constituem historicamente de formas diferentes, não havendo razão para estender um modelo clássico, como o inglês do século XIX, à constituição de classes em todas as sociedades (Ridenti, 1994).

$\mathrm{O}$ autor relativiza a relação base-superestrutura afirmando que a estrutura se liga à ação por meio da experiência. Para Thompson experiência é o modo como as estruturas adquirem a condição de processo e a maneira pela qual a estrutura se faz história. Para o autor não existe nada fora da experiência (Thompson, 1987). 
Nessa perspectiva a classe é uma categoria histórica derivada da observação do processo social através do tempo. A partir dos eventos históricos tomados como evidências empíricas seria possível teorizar essa evidência como uma teoria geral de classe. Segundo Ridenti (1994) Thompson reforça que cabe evitar o equívoco de dar um peso maior à teoria sobre evidência histórica, o que tornaria a ocorrência das classes um processo ideal e não um processo real. Critica também a noção de classe como uma categoria estática e afirma que a tradição sociológica tende a reduzir o sentido de classe social a medidas quantitativas: tantas pessoas nesta ou naquela relação com os meios de produção (Ridenti, 1994).

Sendo assim, nos dois primeiros capítulos do terceiro volume o autor discorre a respeito da formação da classe operária a partir da experiência dos movimentos do radicalismo popular na Inglaterra vivida durante o processo social da Revolução Industrial.

Tais movimentos se fortaleceram por meio da formação de grupos de resistência denominadas sociedades de correspondência. Entretanto, essas sociedades perderam coesão principalmente devido ao enfraquecimento revolucionário da França após a subida de Napoleão, já que "a disposição moral dos reformadores ingleses estava intimamente envolvida com os destinos da França" (1987: 13). Por outro lado, esse enfraquecimento do jacobinismo levou a uma baixa da guarda por parte das atividades antijacobinistas dando fôlego novo ao radicalismo que passou a se manifestar por meio da clandestinidade e de investidas como as dos luddistas (Thompson, 1987.

Thompson afirma que os anos que precederam esses movimentos radicais conformaram o período de consolidação da consciência de classe inglesa (Thompson, 1987). De 1830 em diante os trabalhadores amadureceram sua consciência de classe, processo esse que envolveu o esforço de auto-aperfeiçoamento dos trabalhadores a despeito das carências de formação e contou com as Sociedades de Leitura que objetivavam aumentar a consciência política. A disseminação de panfletos e a luta pela liberdade de imprensa também se constituíram em importantes elementos para o desenvolvimento da consciência de classe inglesa. Destaca-se que existiam dois públicos radicais leitores dos periódicos: os da classe média e os dos operários, demonstrando que não havia homogeneidade dentro da classe trabalhadora. 
Thompson ressalta durante esse período o papel da igreja metodista em isolar seus seguidores dos impactos de qualquer contestação política por meio da imprensa.

Nesse processo de articulação dos movimentos dos trabalhadores destaca-se a atuação de diversos líderes e suas influências na construção da consciência de classe operária consolidada nos anos de 1831-1835. Thompson (1987) chama a atenção para o fato de que a consciência de classe poderia ser vista a partir de dois aspectos: de um lado havia uma consciência da identidade de interesses entre trabalhadores das mais diversas profissões e de outro havia uma consciência da identidade dos interesses das classes operárias ou produtivas enquanto contrários aos de outras classes. $\mathrm{O}$ autor ressalta a contradição interna das classes produtivas. Embora a classe média e a classe operária fizessem parte das classes produtivas, a "consciência de classe" da classe média era mais interessada em si mesma do que qualquer outra: "entre todos os governos, o governo das classes médias é o mais esmagador e sem remorsos ao subjugar a classe trabalhadora" (Thompson, 1987:428, Vol. III). Embora os artesãos londrinos tivessem conseguido construir uma liderança coesa, continuava a existir um grande fosso entre eles e a massa dos trabalhadores de ofícios menos "honrosos".

Para Thompson a consciência de classe se configura em consciência política. E afirma que a relação homogênea não é comum e existe a possibilidade de uma classe se ver em antagonismo com a outra, sem necessariamente haver base material para isso. Para Thompson a classe não é dominada pelo capital, pois os agentes se articulam, lutam, buscam alternativas.

Outro ponto importante refere-se ao fato de que para o autor não há classe sem consciência. O operário só existe a partir da consciência, sendo que essa advém das experiências e das relações sociais. Thompson critica o fato de que no trabalho de Marx só aparecem variações de consciência dominante e nunca de consciência operária. Para Marx, segundo Thompson, a classe operária existe para o capital e nunca para si mesmo (Ridenti, 1994).

Para Thompson, segundo Ridenti (1994), as classes não existem como entidades separadas que encontram um inimigo e aí começam a lutar. Ao contrário, as pessoas encontram-se em uma sociedade estruturada de determinada maneira, com certas formas de exploração e dominação, elas identificam pontos de interesse antagônicos, começam a lutar em torno dessas questões e no processo de luta se 
descobrem como classes. Entretanto, o autor ressalta que nenhum exame das determinações objetivas e nenhum modelo teorizado a partir dele, pode colocar uma classe e consciência de classe numa equação simples. A classe realiza-se quando os sujeitos vivem suas relações produtivas, experimentam suas situações determinadas dentro do conjunto das relações sociais com suas expectativas e cultura herdada, e quando eles lidam com essas experiências em termos culturais. De tal forma que nenhum modelo pode fornecer o que seria a verdadeira formação de classe para certo estágio do processo. Nenhuma formação de classe real da história é mais verdadeira ou mais real que qualquer outra, e a classe se define como, de fato, ela se realiza. (Ridenti, 1994).

Por outro lado essa perspectiva é criticada por Anderson (1980) já que o conceito de classe se torna dependente de uma soma de vontades individuais. Os construtores imediatos da história seriam as classes, elas mesmas compostas por homens e mulheres individuais. De modo que o agir se desenvolve nos homens e não nas classes (Anderson, 1980). Toda a ênfase está na construção das classes pelos indivíduos, em detrimento das condições que lhe são objetivamente dadas. O problema fundamental de análises como a de Thompson estaria, para Anderson, no fato de que se processos históricos fundamentais são a resultante involuntária de uma dualidade ou pluralidade de forças voluntárias de classes chocando-se entre si, isso não explica a ordem social (Anderson, 1980).

Nessa perspectiva, não seria possível responder satisfatoriamente à questão da existência da ordem na sociedade e tampouco saber as razões da ocorrência da ruptura com ela em determinados momentos e não em outros, pois Thompson não aceitaria a noção que permitiria encontrar essas respostas, ou seja, a do modo de produção. Thompson ainda deixa de lado a mistificação em que muitas vezes se envolve essa experiência como nos casos históricos de experiências de lutas calcadas na fé religiosa ou na lealdade nacional (Anderson, 1980).

Autores como Anderson indicam que existe sobreposição entre as lutas de classe e a contradição entre forças produtivas e relações de produção no capitalismo. Ainda que não sejam idênticas e só venham a unir-se em determinados momentos históricos, não caberia entender uma sem a participação da outra, pois a própria força de trabalho é o principal componente das forças produtivas. Anderson (1980) assinala que a experiência empírica não é simplesmente ilusão, nem se confunde com 
os próprios fundamentos não empíricos do real. Não haveria razão, do ponto de vista do materialismo histórico, para privilegiar a teoria em detrimento da prática e viceversa. Nem em destacar a ação dos homens em detrimento das condições dadas pela história e vice-versa. Teoria e prática, ciência e experiência, condições objetivas e subjetivas, conteúdo e forma, não podem ser vistos como polaridades distintas e excludentes, mas pensadas como parte da mesma realidade, tomada como totalidade contraditória (Anderson, 1980).

\subsection{Considerações a partir dos três referenciais}

A partir do que foi apresentado verifica-se que o conceito de classe social pode ser abordado perante três dimensões que compõem com peso maior ou menor o eixo norteador dos trabalhos dos autores em discussão: classe como descritor da estrutura econômica e iniqüidade social atrelada às relações de exploração no processo de produção capitalista (Marx); classe como prestígio e/ou status relacionada às oportunidades de mercado e propriedade de bens ou honras (Weber); classe como representação dos estilos de vida, concretizados no espaço social onde estão dispostas as posições relativas dos agentes das práticas produzindo habitus diversos (Bourdieu); e classe como processo histórico e potencial agente de ação social (Thompson).

Sabe-se, entretanto, que cada dimensão expõe apenas partes do objeto e por isso mesmo existe a dificuldade de se identificar um conceito de classe social que considere a relação entre as três dimensões e que também contemple classe social como sociabilidade. Além disso, deve-se considerar a realidade atual "globalizada" e pautada pela reestruturação econômica que influencia diretamente o caráter das relações entre os diversos grupos sociais existentes. Ressalta-se ainda que as relações de classe não são empiricamente observáveis em sua totalidade, tendo sido apreendidas apenas por elementos empíricos como desigualdades nas posições econômicas ou desigualdade de renda e de posse de propriedades, sendo que a forma como as relações entre as classes se dão e a maneira de apreendê-las é algo que deve ser construído (Sallum Júnior, 1998). 
Mesmo diante dessas questões não se pode negar que classe social permanece como um conceito importante para realizar a ligação entre a estrutura social e ação social e que pode ser utilizado como conceito que organize as investigações de questões associadas a iniqüidades sociais e diferenciação social como afirma Crompton (1998).

Sabe-se que a polarização econômica vem se agudizando cada vez mais desde a crise da década de 70 , em que as iniqüidades voltaram a se acentuar no ocidente relacionadas principalmente a fatores como a criação de subclasses devido às mudanças na estrutura ocupacional com o aumento tecnológico e a diminuição da necessidade de trabalhadores manuais e não especializados, além da instituição de trabalhos de baixa remuneração, redução das horas de trabalho, contatos precários e trabalhos temporários. Com o avanço tecnológico houve um aumento da necessidade de trabalhadores intelectuais e aumento de desemprego entre os trabalhadores manuais. Houve assim uma polarização entre os trabalhadores intelectuais e os trabalhadores informais, fruto do aumento do desemprego. Enquanto tem havido a diminuição do proletariado industrial, o proletariado de serviços tem aumentado (Crompton, 1998).

Destaca-se que Antunes (2007) discordaria dessa última afirmação já que num período marcado pela mundialização e financeirização dos capitais não é possível tratar de modo independente os três setores da economia (indústria, agricultura e serviços) na medida em ocorre a interpenetração desses capitais como no caso da agroindústria, indústria de serviços e serviços industriais. E o autor chama a atenção para o fato de se reconhecer a interdependência setorial é muito diferente de se falar em sociedade pós-industrial, concepção carregada de conotação política.

O autor ainda chama a atenção para a necessidade se considerar uma concepção ampliada de trabalho que incorpore os trabalhadores produtivos que participam diretamente da produção de mais valia transcendendo as atividades tipicamente industriais; os trabalhadores improdutivos que não criam mais-valia pois seus produtos são utilizados como serviços; os trabalhadores que produzem trabalho imaterial, predominantemente intelectual; o proletariado rural, o proletariado precarizado com trabalhos temporários e os desempregados (Antunes, 2007).

Diante de tal diversidade e fragmentação torna-se difícil a mobilização social da classe trabalhadora, pois se obstaculiza a concretização do processo estrutura- 
consciência- ação pelos trabalhadores. Sendo assim, discutir o conceito de classe diante dessas contradições permanece essencial para a compreensão de nossa condição social contemporânea (Crompton, 1998).

Diante de tais constatações, o presente trabalho tomará o conceito de classe como descritor da estrutura econômica e iniqüidade social atrelada às relações de exploração no processo de produção capitalista a partir do referencial marxista. Nesse estudo também serão atreladas as diferentes formas de consumir e de viver dos grupos sociais consideradas como determinadas e subsumidas pelo momento de produção ${ }^{5}$. Nessa perspectiva tal conceito de classe será operacionalizado por meio da categoria reprodução social.

\subsection{A centralidade do trabalho na sociologia contemporânea}

Após a discussão do conceito de classes a partir de teóricos clássicos é necessário analisar a questão da centralidade do trabalho na sociologia contemporânea, na medida em que tal debate é cada vez mais incorporado nas formulações de autores denominados pós-modernos como Claus Offe, André Gorz e Jürgen Habermas.

Teixeira (2009) critica a produção dos teóricos que afirmam o fim da sociedade do trabalho apontando as idéias centrais e desconstruindo argumentos levantados, com base em releitura de Marx diante das novas exigências do presente.

Em relação a André Gorz, Teixeira afirma que sua principal tese está fundamentada na perda da materialidade do trabalho e no fato de que hoje a classe trabalhadora não é mais a mesma, o que provoca a descentralização do conflito de classes. Esse teórico afirma que diante das exigências da modernidade o trabalhador qualificado que dominava as forças da natureza foi substituído pelo especializado, que não domina mais o processo de trabalho em sua totalidade. Para o autor, o trabalho perdeu assim a sua materialidade, o que implica em reconsiderar a centralidade do trabalho na vida social. A perda da materialidade é exemplificada

\footnotetext{
5 Variáveis relativas a consumo de bens e serviços vêm historicamente sendo utilizadas na epidemiologia em conjunto com variáveis relativas à produção. Porém, conforme Yonekura (2011), à exceção da composição dos grupos sociais homogêneos do qual o presente estudo parte, não se observa um modelo hierárquico de base marxista em que o consumo esteja subsumido à inserção na produção.
} 
pela impossibilidade de avaliação do desempenho individual. Além disso Gorz acrescenta elementos como a redução do tempo do trabalho e o declínio acentuado do assalariamento da força de trabalho para explicar a substituição da categoria trabalho por outras consideradas mais centrais na vida social atual (Teixeira, 2009).

Seus argumentos, entretanto carecem de fundamentação empírica pois no que diz respeito ao tempo de trabalho, a tendência que se observa em todo mundo é de uma crescente intensificação, mediante a eliminação dos tempos mortos e da utilização de mecanismos de controle das atividades dos trabalhadores. Teixeira (2009) aponta que a conquista da jornada de 36 horas em alguns países europeus se constitui em letra morta devido ao enfraquecimento da regulação pública. Quanto à diminuição do assalariamento, apresenta ainda estatísticas de países como França, Espanha, Japão e EUA em que a compra e venda da força de trabalho são ainda as formas principais de contratação.

Em relação à perda da materialidade devido ao aumento do setor de serviços e a impossibilidade de se medir a produtividade desses trabalhadores - mesma base dos argumentos de Offe - é importante apontar que atualmente existe intersecção entre os setores da economia com a expansão da indústria de serviços e dos serviços industriais como apontado anteriormente por Antunes (2007) o que relativiza a afirmação de Offe e de Gorz a respeito da supremacia do proletariado de serviços. Offe afirma ainda que os critérios da racionalidade capitalista, desenvolvidos pela produção de mercadorias, não podem ser transferidos para o setor de serviços o que dificulta a avaliação da produtividade dos trabalhadores. Teixeira contra argumenta ao identificar que o trabalho no setor de serviços tem se tornado cada vez mais padronizado, rotineiro e uniformizado passando a ser avaliado por meio da utilização de banco de dados e de sistemas de intercâmbio eletrônico. Assim, a eficiência e a produtividade dos trabalhadores podem ser mensurados e avaliados da mesma forma como acontece na indústria (Teixeira 2009).

Habermas, outro teórico discutido por Teixeira, considera insuficiente a teoria social de Gorz e Offe pois lhes falta uma teoria mais ampla capaz de analisar a modernidade. Habermas identifica a formação social como resultado da conjugação do progresso técnico-científico e da evolução de um processo de interação orientado por normas mediadas linguisticamente. Nesse sentido Habermas aponta a limitação do materialismo histórico por ter agregado interação e trabalho numa única totalidade 
homogênea e unificada e propõe a reconstrução desse referencial. Para Habermas, a atividade produtiva, como qualquer ação humana está inserida em uma rede de interação social o que a torna dependente das condições de comunicação. Até um ato produtivo individual vale-se da linguagem. Trabalho e interação assim constituem duas dimensões que obedecem a realidades distintas: a da interação ou da ações comunicativas que se apóiam nas interações culturais partilhadas e a do trabalho que se rege por mecanismos sistêmicos que independem da intenção dos sujeitos. Para autor, a limitação do referencial do materialismo histórico se concentra no fato de que as forças produtivas são consideradas motor do desenvolvimento social, sendo que para ele a racionalidade do mercado somente se impõe sobre as ações práticomorais quando se inicia um processo no qual a ação comunicativa se abre para a expansão colonizadora das forças produtivas, isto é das ações técnicas sobre o mundo das ações práticas. Assim são as ações prático-morais e não as ações instrumentais, isto é da esfera da produção, os fatores diretamente responsáveis pela evolução social.

Uma crítica a essas concepções é trazida por Souza (2010) que considera que Habermas imaginava um mundo:

(...) [no qual seria possível] manter o mercado/Estado dentro dos limites bem definidos de modo a possibilitar o desenvolvimento das virtualidades de uma "razão comunicativa", pensada como possibilidade concreta precisamente pela expansão da boa educação para amplos setores. Habermas requentava a velha esperança iluminista de que novos potenciais de reflexividade e possibilidade de ação crítica poderiam conduzir a uma sociedade capitalista de novo tipo (Souza, 2010. p. 38).

Teixeira (2009) enfatizando aspectos insuficientes na proposição de Habermas, afirma que o autor não reconstrói o materialismo histórico mas o substitui por uma teoria da evolução social na qual a linguagem tem primazia absoluta sobre o trabalho. Além disso, realiza uma análise superficial do trabalho de Marx ao reduzilo a uma investigação puramente econômica das leis que governam a produção e distribuição da riqueza social.

Compartilha-se aqui das críticas formuladas por Teixeira às teses de Gorz e Offe, que não encontram parâmetros explícitos na realidade do trabalho contemporâneo. Ao mesmo tempo, concorda-se com a interpretação de que a leitura 
de Habermas não faz justiça à teoria do materialismo histórico. Defende-se que a configuração atual do capitalismo pode ser interpretada à luz da teoria marxista.

Teixeira (2009) nos ajuda a compreender essa configuração. Para aumentar a produtividade do trabalho, o capital é obrigado a reduzir os gastos com trabalho improdutivo que não agrega valor de troca, além de levar às últimas consequências a intensificação do trabalho. O capital, assim, passou a reagrupar em numa única unidade de produção as diferentes fases do ciclo de acumulação, antes separadas espacial e temporalmente pela divisão social do trabalho. Nesse sentido a cooperação complexa apresenta-se como forma de produção de mercadorias muito diferente daquela da grande indústria na qual o capital-dinheiro cabia aos bancos, o capital produtivo aos industriais e o capital-mercadoria aos comerciantes. Da mesma forma que as empresas foram levadas a unificar as diferentes formas de capital, a reestruturação produtiva, com seus novos métodos e técnicas de contratação e gerenciamento, vem recompondo as diferentes fases do processo criando um novo tipo de trabalhador coletivo capaz de aumentar a produtividade e reduzir gastos. Nessa reconfiguração, os trabalhadores devem ser capazes de resolver não apenas os problemas decorrentes de sua ocupação mas também os de sua empresa. Assim, o trabalhador especializado vem sendo substituído pelo polivalente (diferente do afirmado por Offe) e não tendo mais sua especificidade, perde sua força de agregação e passa a desacreditar da representação e da necessidade de mediação entre o sindicato e a empresa. (Teixeira, 2009).

As novas formas de contratação da força de trabalho tais como trabalho em domicílio, terceirizado e trabalho por conta própria transformam seus proprietários em verdadeiros comerciantes na medida em que sua capacidade de trabalho passa a ser mediada pela venda dos resultados do seu trabalho. $\mathrm{O}$ trabalhador sente-se assim dono de sua atividade e a exploração é mascarada pois o trabalhador e o capitalista se encontram e se separam na circulação de mercadorias, confrontam-se como simples comerciantes e não como representantes de interesses antagônicos. Teixeira afirma:

Se na época da grande indústria a substituição da força muscular pela máquina permitiu a exploração do trabalho feminino e das crianças de todas as idades, na cooperação complexa, as coisas são bem piores. Agora é a desmaterialização da produção, ao transformar a sociedade numa "fábrica sem muros", que permite abolir qualquer direito de proteção ao trabalho (...). A cooperação complexa é, por isso, a forma mais ideal de produção de mercadorias. Nela, o capital não só curte a 
pele do trabalhador pra transformá-la em valor, mas se faz dono da sua alma e da sua consciência (Teixeira, 2009.p.139).

Nessa perspectiva é impossível negar o trabalho como categoria sociológica central e conseqüentemente a potencialidade explicativa do referencial marxista em relação à realidade social pois vive-se a sofisticação do processo de exploração do trabalho reconfigurada mediante as atuais necessidades de reprodução do capital. 
3. Utilização do conceito de classes sociais em investigações epidemiológicas na perspectiva da Epidemiologia Crítica 


\section{3- Utilização do conceito de classes sociais em investigações epidemiológicas na perspectiva da Epidemiologia Crítica}

A relação entre processo saúde-doença e classe sociais já foi demonstrada por diversos estudos epidemiológicos. Yonekura (2011), por meio de uma revisão sistemática teórica e quantitativa, identificou que $91,9 \%$ dos estudos levantados mostraram que as classes com menor acesso à riqueza social apresentaram maiores prevalências ou incidências de problemas de saúde em relação às outras classes. Ao classificar os estudos em dois grupos (classe social como determinante e classe social como fator associado) e verificar novamente a associação entre a classe e o desfecho, observaram-se resultados positivos maiores. Dos estudos que utilizaram a categoria classe social como determinante, $97,7 \%$ apontaram diferenças significativas entre as classes sociais e os problemas de saúde estudados (Yonekura, 2011).

A mesma autora, descreveu os modelos operacionais do conceito de classe nos estudos epidemiológicos encontrados. Do total de 28 trabalhos, 14 são latino americanos, sendo 64,3\% brasileiros e os demais se distribuíram entre Equador, Chile, México, Venezuela e Costa Rica. Os estudos se concentraram na década de 80 (Yonekura, 2011). Esse período coincide com a mobilização de vários atores sociais para a contestação das desigualdades sociais aprofundadas com a crise mundial do capitalismo nos anos 70 (Breilh, Granda, 1989).

Dos 14 trabalhos latino-americanos, a autora excluiu cinco por utilizar o conceito de classe focado no poder de consumo e assim embasarem-se em definição teórica inadequada de classe social, constituindo-se na verdade em operacionalização do conceito de extrato sócio-econômico (Yonekura, 2011).

No quadro abaixo estão apresentados os nove trabalhos restantes com as diferenças dos modelos operacionais de classe social, considerando que as dimensões de análise estão relacionadas ao lugar que o sujeito ocupa no sistema de produção capitalista. Verifica-se que nos estudos são utilizados diferentes tipos de divisão de classes e diversos critérios para diferenciá-las. Ressalta-se que grande parte dos autores - Barros (1986), Behm (1980), Bronfam (1984), Carvalheiro (1986), Lombardi (1988), Solla (1992) - trabalham principalmente com a classificação em burguesia e proletariado e suas possíveis subdivisões. 
Quadro 1- Definição das diferentes propostas latino-americanas de operacionalização do conceito de classe de acordo com a estrutura de classe e diferença entre classes e a inserção na produção. Yonekura, 2011.

\begin{tabular}{|c|c|c|}
\hline Estudo & Divisão da classe & Diferença entre as classes \\
\hline $\begin{array}{l}\text { Barros MBA. A utilização do } \\
\text { conceito de classe social nos } \\
\text { estudos } \\
\text { epidemiológicos: uma proposta. } \\
\text { Rev. Saúde Pública. 1986; 20(4): } \\
\text { 269-73. }\end{array}$ & $\begin{array}{l}\text { Burguesia empresarial, pequena burguesia, } \\
\text { burguesia gerencial, proletariado, } \\
\text { subproletariado. }\end{array}$ & $\begin{array}{l}\text { Posição na ocupação, tipo de } \\
\text { ocupação, propriedade, renda e } \\
\text { número de empregados. }\end{array}$ \\
\hline $\begin{array}{l}\text { Behm H. Economic and social } \\
\text { determinants of mortality in Latin } \\
\text { America. Rev Cuhana Adm Salud. } \\
\text { 1980; 6(1): 1-30. }\end{array}$ & $\begin{array}{l}\text { Burguesia, grupos médios, proletariado e } \\
\text { trabalhadores agrícolas }\end{array}$ & $\begin{array}{l}\text { Posição na ocupação, tipo de } \\
\text { ocupação, escolaridade. }\end{array}$ \\
\hline $\begin{array}{l}\text { Breilh J, Granda E, Campaña A, } \\
\text { Betancourt O. Clase social y } \\
\text { desigualdad ante la muerte en } \\
\text { Quito. In: Breilh J, Granda E, } \\
\text { Campaña A, Betancourt O. Ciudad } \\
\text { y muerte infantil. Quito: CEAS; } \\
1983 \text {. }\end{array}$ & $\begin{array}{l}\text { Grupo } 1 \text { - grupo social ligado à indústria } \\
\text { pecuária, mineração e agricultura de } \\
\text { subsistência. Grupo } 2 \text { - vinculado à produção } \\
\text { de mercadorias. Grupo } 3 \text { - ligado diretamente } \\
\text { à produção capitalista. } \\
\text { Grupo } 4 \text { - subproletariado ("exército de } \\
\text { reserva"). Grupo } 5 \text { - setor da população de } \\
\text { classe média ligado ao Estado. Grupo } 6 \text { - } \\
\text { classe dominante }\end{array}$ & $\begin{array}{l}\text { Posição na ocupação e tipo de } \\
\text { ocupação. }\end{array}$ \\
\hline $\begin{array}{l}\text { Bronfman M, Tuirán R. La } \\
\text { desigualdad ante La muerte: clases } \\
\text { sociales y mortalidad em La niñez. } \\
\text { Cuad. méd. soc. 1984; 29/30; 53- } \\
75\end{array}$ & $\begin{array}{l}\text { Burguesia, nova burguesia, pequena } \\
\text { burguesia tradicional, proletariado típico ou } \\
\text { atípico, força de trabalho livre. }\end{array}$ & $\begin{array}{l}\text { Posição na ocupação, tipo de } \\
\text { ocupação, setor de atividade, } \\
\text { número de empregados, } \\
\text { propriedade dos meios de } \\
\text { produção, grau de controle do } \\
\text { processo de trabalho, } \\
\text { escolaridade, forma em que } \\
\text { recebem a parte da riqueza social. }\end{array}$ \\
\hline $\begin{array}{l}\text { Carvalheiro } \quad \text { JR. Processo } \\
\text { migratório e disseminação de } \\
\text { doenças. In: Textos de apoio. Rio } \\
\text { de Janeiro: ABRASCO; } 1986 .\end{array}$ & Burguesia, proletariado e subproletariado. & $\begin{array}{l}\text { Posição na ocupação, tipo de } \\
\text { ocupação, renda, característica da } \\
\text { moradia. }\end{array}$ \\
\hline $\begin{array}{lccc}\text { Lombardi C, } & \text { Bronfman } & \text { M, } \\
\text { Facchini LA } & \text { et } & \text { al. } \\
\text { Operacionalização do conceito de } \\
\text { classes sociais em estudos } \\
\text { epidemiológicos. }\end{array}$ & $\begin{array}{l}\text { Burguesia, nova pequena burguesia, pequena } \\
\text { burguesia tradicional, proletariado não típico, } \\
\text { proletariado típico, subproletariado. }\end{array}$ & $\begin{array}{l}\text { Posição na ocupação, tipo de } \\
\text { ocupação, papel na organização } \\
\text { social do trabalho, escolaridade, } \\
\text { forma em que recebem a parte da } \\
\text { riqueza social. }\end{array}$ \\
\hline 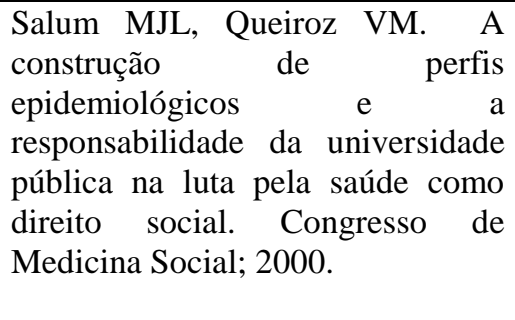 & $\begin{array}{l}\text { - GSH1*: famílias com Formas de } \\
\text { Trabalhar Adequadas (FTA) e Formas de } \\
\text { Viver Adequadas (FVA). } \\
\text { - GSH2: famílias com Formas de } \\
\text { Trabalhar Adequadas (FTA) e Formas de } \\
\text { Viver Inadequadas (FVI) ou com Formas } \\
\text { de Trabalhar Inadequadas (FTI) e Formas }\end{array}$ & 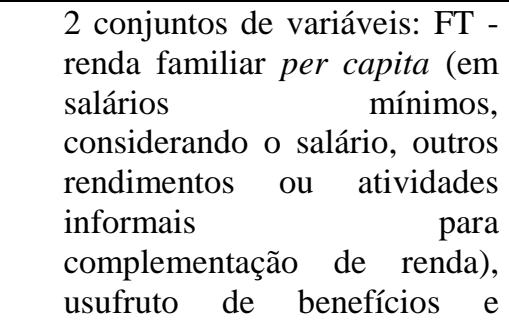 \\
\hline
\end{tabular}




\begin{tabular}{|c|c|c|}
\hline & $\begin{array}{l}\text { de Viver Adequadas (FVA). } \\
\text { - GSH3: famílias com Formas de Trabalhar } \\
\text { Inadequadas (FTI) e Formas de Viver } \\
\text { Inadequadas (FVI). }\end{array}$ & $\begin{array}{l}\text { registro formal no trabalho. } \\
\text { FV: propriedade da habitação } \\
\text { e o grau de agregação social } \\
\text { (vida associativa) e o usufruto } \\
\text { de alguma atividade de lazer. }\end{array}$ \\
\hline $\begin{array}{l}\text { Silva GB. } \quad \text { Critérios } r \\
\text { estratificação } \\
\text { Pública. } 1981 ; 15(1) ; 38-45\end{array}$ & $\begin{array}{l}\text { A. Posição de classe: Atividades não } \\
\text { assalariadas manuais ou não-manuais - } \\
\text { empregador, trabalhador autônomo - e } \\
\text { Atividades assalariadas - manuais ou não- } \\
\text { manuais. } \\
\text { B. Situação de classe: menos de um SM, de } 1 \\
\text { a } 2 \text { SM, de } 3 \text { a } 7 \text { SM, de } 7 \text { a } 10 \text { SM, mais de } \\
10 \text { SM. }\end{array}$ & $\begin{array}{l}\text { Posição na ocupação, relação no } \\
\text { sistema de produção, situação de } \\
\text { classe e renda. }\end{array}$ \\
\hline $\begin{array}{l}\text { Solla JJSP. Classe social e saúde: } \\
\text { um estudo sobre a utilização deste } \\
\text { conceito na investigação } \\
\text { epidemiológica [dissertação de } \\
\text { mestrado]. Bahia: Universidade } \\
\text { Federal da Bahia; 1992. }\end{array}$ & $\begin{array}{l}\text { Burguesia, pequena burguesia tradicional, } \\
\text { nova pequena burguesia, proletariado típico } \\
\text { ou atípico, força de trabalho livre. }\end{array}$ & $\begin{array}{l}\text { Posição na ocupação, tipo de } \\
\text { ocupação, quantidade de } \\
\text { empregados, escolaridade, }\end{array}$ \\
\hline
\end{tabular}

Fonte: Adaptado de Yonekura, 2011

Yonekura (2011) identificou também 13 critérios que dividiram as classes sociais fundamentando-se numa compreensão de saúde e doença que coloca no centro da explicação dos determinantes da saúde, o trabalho - a produção capitalista - e, a ele subordinado, a vida - o consumo sob o comando do processo de acumulação capitalista. Sendo assim, as formas de trabalhar foram definidas pela posição na ocupação, tipo de ocupação, renda, número de empregados, registro formal de trabalho, benefícios oriundos do trabalho e uso de tecnologia. As formas de viver foram definidas pelo nível de escolaridade, agregação social, localização da moradia no bairro, status, atividades de lazer, propriedade da habitação, tamanho da moradia, número de membros da família. Mais da metade dos trabalhos latinoamericanos $(55,6 \%)$ agregaram as formas de trabalhar e de viver para compor os modelos e os demais utilizaram apenas as formas de trabalhar. Nenhum trabalho utilizou as formas de viver isoladamente.

Barros (1986), Lombardi et al (1988) e Solla (1996) discutem a dificuldade de operacionalização do conceito de classe nos estudos epidemiológicos por meio de questionários padronizados que classificam famílias e indivíduos. A possibilidade de analisar os perfis epidemiológicos em relação às classes sociais e frações de classe fica sujeita às dificuldades de se definir o próprio conceito de classe social, bem como as definições de cada fração (Barros, 1986). Lombardi (1988) ressalta que as 
limitações da técnica de entrevistas por meio de questionários e as dificuldades metodológicas de delinear variáveis confiáveis sobre a consciência e a prática política das classes dificultam a operacionalização do conceito, restringindo-o à instância econômica, sem englobar a jurídico-política e a ideológica.

Por outro lado, mesmo que os questionários não permitam apreender as mutações internas das classes e em suas relações com as outras classes e com a estrutura social, é possível identificar grupos sociais e a maneira como a inserção de classe interfere no comportamento dos indivíduos (Lombardi, 1988). Dessa forma, embora esse processo concentre-se na dimensão econômica, as vantagens de incluí-lo em estudos epidemiológicos superam, em muito, suas limitações (Lombardi, et al, 1988).

Os três trabalhos estão centrados no âmbito da produção. Segundo Barros (1986) ao se considerar as diferentes inserções no processo produtivo, para além dos diferenciados níveis de consumo, pode-se superar a prática de descriminar grupos sociais segundo critérios arbitrariamente selecionados pelos investigadores, sem respaldo na realidade histórica, social e econômica, como por exemplo, as variáveis tradicionais de estratificação, como renda e escolaridade que, isolados, configuram grupos humanos que não compartilham necessariamente a mesma situação de classe (Lombardi et al. 1988).

Nessa perspectiva, com a finalidade de realizar análise estrutural superando a utilização de variáveis isoladas, autores como Lopes (1993) buscaram investigar os efeitos das rápidas transformações da conjuntura econômica sobre a inserção social dos grupos. $\mathrm{O}$ autor estudou a rápida mudança nas proporções de pobreza no Brasil com o objetivo de traçar um quadro contemporâneo da pobreza urbana caracterizando as diversas regiões do país. Lopes cruzou duas dimensões: uma que agrupou a população segundo a satisfação ou não das necessidades básicas e outra que separou a população em linhas de pobreza. Para tanto, fez uso de linhas de indigência (valores per capita que cobrem apenas gastos com alimentação) e de pobreza (valores per capita para fazer face com os gastos de todas as necessidades básicas alimentares e não alimentares), obtidas por meio de diversos dados calculados por Sonia Rocha em 1991 e outros obtidos por Vera Lucia Fava em 1984 a partir do ENDEF (Estudo Nacional de Despesa Familiar de 1974/75). Partindo dessas duas dimensões e utilizando dados secundários do PNSN (Pesquisa Nacional 
de Saúde e Nutrição) de 1989 o autor classificou os grupos em indigentes (I), pobres não indigentes (Pn) e não pobres (NP) e os caracterizou segundo variáveis como: sexo, idade e cor da pele dos moradores e do chefe de família, composição familiar, tipo de trabalho e renda dos chefes e dos moradores, inserção no mercado de trabalho dos chefes de família, escolaridade do chefe de família, características do domicílio, posse de eletrodomésticos, entre outros. Uma das principais constatações foi a de que as proporções de indigentes e pobres são heterogêneas nas diversas regiões do país sendo muito maiores nas regiões Centro-Oeste, Norte e Nordeste e as condições de vida comparativamente muito piores.

Outra proposta de classificação de grupos sociais é a Proposta de Construção de Indicadores Compostos (PCIC) de Akerman (1997) que conduz à definição das áreas homogêneas do território através da articulação de variáveis socioeconômicas e de meio ambiente tendo como base conceitual a qualidade de vida. A PCIC resgata "a noção de risco coletivo", levando em conta indicadores compostos gerados em processos participativos e fazendo "do ato de medir e analisar as condições de vida e a situação de saúde de uma dada população um exercício de negociação transetorial, criando possibilidades de compreensão mais holística do espaço urbano".

Autores como Campaña (1997) apontam as limitações de trabalhos voltados para a noção de qualidade de vida:

(...) os estudiosos da 'qualidade de vida' no mundo capitalista, apesar da quantidade de investigações realizadas, nunca estão completamente de acordo sobre o quê de fato esta qualidade significa e como deve ser medida. (...) [Não incluem, no núcleo conceitual que orienta a definição dos indicadores], (...) a análise da estrutura de classes da sociedade, que estabeleça a posição real das classes, dos grupos e dos indivíduos dentro de dada sociedade (...) fazendo - apesar da filigrana estatística (...) aproximações (...) descritivas externas (...) reduzindo a explicação do problema humano ao espaço ou ao momento da circulação mercantil e do consumo (...) [e considerando] (...) os seres humanos sob perspectiva antropologista abstrata, ideal, generalizada. No melhor dos casos reconhece-se que existem homens ricos e pobres (Campaña, 1997).

Diante de todo o esforço de se operacionalizar o conceito de classes sociais é importante ressaltar a necessidade de distinguir os conceitos de classe social e estratificação social (Possas, 1989). O conceito marxista de classe social não está relacionado com critérios e valores diferentes que determinam o agrupamento de pessoas, ao contrário da utilização da estratificação social. Este último possibilita vários recortes da população a depender do recorte metodológico empregado. 
Entretanto afirma que "a utilização de critérios de estratificação não é incompatível com o conceito marxista de classe social", a depender da metodologia empregada para classificar a população (Possas, 1989: 161).

Solla (1992) contribui com a discussão ao apontar outras necessidades de superação de problemas na utilização do conceito de classe social tais como: a consideração das peculiaridades de cada sociedade e os processos dinâmicos que nela ocorrem; a consideração que nem todos os conceitos podem ser reduzidos a variáveis na investigação empírica; e o aprofundamento de questões teórico-conceituais, como o ponto de corte de variáveis quantitativas, a quantidade de variáveis necessárias para compor um indicador, a inclusão da população não diretamente inserida na dimensão econômica como os estudantes e a classificação de indivíduos com mais de uma inserção na produção.

Diante de questões como essas, Yonekura (2011) ressalta a importância de se analisar e adaptar as formas de operacionalização do conceito de classe de forma a potencializar a utilização dessa categoria em estudos empíricos epidemiológicos. Para melhor compreender as desigualdades sociais é válido incorporar variáveis que reflitam diferentes ângulos da reprodução social. 
4. Aproximando-se da operacionalização do conceito de classe por meio da categoria reprodução social 


\title{
4- Aproximando-se da operacionalização do conceito de classe por meio da categoria reprodução social
}

Partir do conceito de classe social para alcançar a categoria reprodução social é um grande desafio teórico a ser enfrentado. A reprodução social, de acordo com Salum, Queiroz (1997),

\begin{abstract}
"retém a essência explicativa da conformação heterogênea do coletivo - as relações sociais de produção; articula, de modo hierarquizado, os dois momentos constituintes (produção e consumo) da produção da vida social, subordinando as formas de viver às formas de trabalhar do coletivo, não dispensando a relativa autonomia de processos mediadores, nem sempre tão claramente identificáveis nos vínculos que mantêm com as relações sociais de produção".
\end{abstract}

As autoras se perguntavam:

\begin{abstract}
"como dar conta de evidenciar a heterogeneidade do coletivo num determinado espaço geossocial, superando as dificuldades atinentes à operacionalização do conceito de classe social, porém recuperando, na base teórica do marxismo, a essência explicativa da conformação heterogênea do coletivo - as relações sociais de produção? ( Salum, Queiroz, 1997).
\end{abstract}

Na busca pela resposta, as autoras tomaram como referência os estudos originais de Granda e Breilh (1991) que incorporaram a Reprodução Social e seus dois momentos, o da produção social - formas de trabalhar - e o do consumo formas de viver, como categoria para caracterizar as desigualdades em saúde.

De outra parte - ainda que não mantivessem sintonia estrita com a perspectiva analítica de Possas (1989), que discute a possibilidade de operacionalização do conceito de classe social - as autoras interessaram-se pela estrutura da sua base empírica para: a) caracterizar a heterogeneidade estrutural centrada na captação de indicadores das condições de existência (condições de vida e estilo de vida) e indicadores das condições de trabalho; b) selecionar indicadores que, articulados entre si e ajustados às exigências teóricas da categoria da Reprodução Social, discriminassem diferentes formas de reprodução social (produção e consumo). 
Recuperando também os encaminhamentos de Laurell e Noriega (1989) - que valeram-se do construto teórico do Modelo Operário para constituir grupos homogêneos - Salum e Queiroz (1997, 2000, 2010 $)$ caracterizaram a heterogeneidade do coletivo pela sua decomposição em grupos sociais homogêneos, cunhando essa expressão para designar o conjunto de famílias de um dado espaço geossocial que guardam entre si semelhantes formas de trabalhar e de viver e que, portanto, apresentam características semelhantes de reprodução social.

De acordo com as autoras, o estudo da Fundação SEADE realizado em 1992 foi referência fundamental para ajustar a base teórico-metodológica à base operacional necessária à caracterização dos grupos sociais homogêneos num dado território. Preocupado em caracterizar a pobreza como fenômeno coletivo e engajado no movimento de reorientação das políticas sociais do Estado, aquele estudo encaminhou-se para a construção de grupos homogêneos segundo condições de vida, ao usar simultaneamente diferentes indicadores de condições de existência e de trabalho.

Laurell (1991) ao estudar a relação trabalho-saúde ressalta que em uma sociedade capitalista a produção de valor determina todas as demais atividades sociais e, portanto, também o consumo. Isto implica que o ponto de partida analítico é o da produção.

Laurell (1991), assim se posiciona a respeito da temática:

\begin{abstract}
Un primer terreno de discusión teórica de la medicina social respecto a la relación trabajo-salud se refiere a los conceptos analíticos centrales. Aquí se inscribe la polémica, ya clásica, respecto a dos de ellos, a saber, "proceso de trabajo" e "reproducción social". La discrepancia manifesta tiene dos planos: uno que se refiere a cuál de los dos es el concepto más general y outro que se refiere a cuál tiene mayor poder explicativo respecto al proceso salud-enfermedad de los distintos grupos sociales. Revisando la primera cuestión en la perspectiva de los conceptos marxistas generales resulta que no hay tal contraposición, dado que, a este nível de abstracción, el propio Marx los usa indistintamente para significar el proceso de apropiación por parte del hombre de la naturaleza sobre la cual se da la (re)producciín de la sociedad. (Laurell, 1991, p. 254).
\end{abstract}

\footnotetext{
${ }^{6}$ Salum MJL, Queiroz VM. Ensaios sobre a apreensão do objeto da saúde coletiva: uma proposta de construção de perfis epidemiológicos de grupos sociais homogêneos. In: Enfermagem em Saúde Coletiva: lições da prática acadêmica - texto acadêmico gentilmente cedido pelas autoras, parte integrante de obra ainda não publicada.
} 
Nessa perspectiva:

\begin{abstract}
(...) si por "reproducción social" se entiende la unidad contradictoria entre producción y consumo obviamente contiene al concepto "momento de la producción" - que en la sociedad capitalista es el proceso de producción - y, en cuanto pretende dar cuenta tanto de este momento como del momento del consumo, tiene um valor explicativo mayor respecto al proceso salud-enfermidad. (Laurell, 1991, p. 255).
\end{abstract}

Dessa forma, segundo a autora, os estudos sobre trabalho-saúde voltados para os determinantes sociais, devem se embasar teoricamente no conceito de processo de trabalho que nas sociedades capitalistas se traduzem em processos de produção. Esse conceito desdobrado permite estudar a realidade concreta da lógica da acumulação (processo de valorização) e seu meio (processo laboral) com um modo específico de trabalho-desgaste e de enfrentamento de classe, que por sua vez determinam um padrão particular de reprodução. Este, ao se combinar com o desgaste, se constitui em um processo de saúde-doença específico para cada grupo social (Laurell, 1991).

\title{
4.1. Proposta de operacionalização da categoria reprodução social
}

A proposta de Salum e Queiroz $(1997,2000,2010)$ busca contemplar os âmbitos de produção e consumo do processo de reprodução social a partir da operacionalização da construção de grupos sociais homogêneos. Ressalta-se que tal modelo compõe o conjunto de modelos estudados por Yonekura (2011) entre os modelos de operacionalização do conceito de classe social em investigações, segundo a perspectiva da Epidemiologia Crítica e foi incluído porque as autoras o construíram para ter uma leitura empírica dos potenciais de desgaste e fortalecimento atinentes às formas de reprodução social das classes e grupos sociais, em função do lugar que ocupam na reprodução da vida social (Yonekura, 2011).

Destaca-se que por tomar como eixo norteador o processo de reprodução social na sua totalidade, o momento da produção não se restringe à classificação por ocupações e o momento do consumo abarca outras variáveis que não somente a posse de bens e eletrodomésticos como ocorre com a escala da Associação Brasileira dos Institutos de Pesquisa de Mercado (ABIPEME), por exemplo, que tem por 
objetivo "estimar o poder de compra das pessoas e famílias urbanas, sem pretensão de classificar a população em termos de classe sociais".

A posse de bens e eletrodomésticos ainda tem sido amplamente utilizada em pesquisas que buscam classificar os grupos sociais. O Conselho Australiano de Pesquisa Educacional, por exemplo, realiza pesquisas longitudinais a respeito da juventude australiana e busca chegar em um consenso no que diz respeito a variáveis que relacionem status socioeconômico e classe social. Os pesquisadores utilizam a posse de eletrodomésticos e eletroeletrônicos como medida para determinar riqueza das famílias mas aliam tais variáveis a outras tais como status ocupacional da família baseados na ocupação do pai ou da mãe, além de indicadores compostos a respeito da educação formal dos pais e que relacionam desigualdade, educação e ocupação (Marks, 1999).

Voltando à proposta de Salum e Queiroz (1997, 2000, 2010), as autoras a construíram em três momentos tomando como referência as categorias e as variáveis de corte expostas no Quadro 2, cuja base operacional permite classificar a priori o coletivo estudado, caracterizando a sua heterogeneidade traduzida em última análise na construção dos grupos sociais homogêneos. Além do que, o esquema considera aspectos relativos à dinâmica social e não somente à estrutura.

O primeiro momento corresponde a uma classificação inicial das famílias a partir dos dados coletados e submetidos a variáveis de corte para trabalho e vida, estabelecendo-se em seguida os limites de inclusão/exclusão, a fim de possibilitar a categorização das famílias estudadas ajuizadas segundo os parâmetros de Inclusão (I) ou Exclusão (E), como se vê nos Quadros 3 e 4. Nesse procedimento, as autoras tomaram como referência a construção de escalas setoriais utilizada no estudo da Fundação SEADE (Fundação Sistema Estadual de Análise de Dados), ajustando-a às possibilidades que a base de dados oferecia, prevalecendo na análise o uso de escalas dicotômicas.

O segundo momento diz respeito a uma diferenciação conforme a inserção no momento da produção e do consumo, recorrendo a formas de mensuração do grau de estabilidade/instabilidade das formas de trabalhar e de viver capazes de expressar a heterogeneidade das condições de trabalho e vida e, portanto, a diversidade de carências existentes. A questão da estabilidade/instabilidade é que diferencia o modelo de Salum e Queiroz $(1997,2000,2010)$ dos demais modelos estudados por 
Yonekura (2011) representando a dinamicidade do processo de reprodução social. Assim, as famílias passam a ser aglutinadas em dois grupos diferenciados para formas de trabalhar e dois grupos diferenciados para formas de viver.

- grupo FTE - formas de trabalhar estáveis: aglutina as famílias que detêm 3 ou, no mínimo, 2 atributos de inclusão;

- grupo FTI - formas de trabalhar instáveis: aglutina as famílias que detêm 2 ou 3 atributos de exclusão;

- grupo FVE - formas de viver estáveis: aglutina as famílias que detêm 3 ou, no mínimo, 2 atributos de inclusão;

- grupo FVI - formas de viver instáveis: aglutina as famílias que detêm 2 ou 3 atributos de exclusão.

No terceiro momento, trata-se de concretizar a construção dos grupos sociais homogêneos. Como se vê no Quadro 5, famílias simultaneamente categorizadas com formas de trabalhar estáveis (FTE) e formas de viver estáveis (FVE), passam a constituir o grupo social homogêneo 1 (GSH1); aquelas simultaneamente categorizadas com formas de trabalhar instáveis (FTI) e formas de viver instáveis (FVI) , passam a constituir o grupo social homogêneo 3 (GSH3). Agrupadas em um grupo intermediário, as famílias que simultaneamente reúnem FTE e FVI ou FTI e FVE, constituíram o grupo social homogêneo 2 (GSH2). 
Quadro 2 - Categorias analíticas, categorias empíricas, variáveis para formas de trabalhar e de viver e variáveis de corte utilizadas para definir a heterogeneidade do coletivo

\begin{tabular}{|c|c|c|c|}
\hline $\begin{array}{l}\text { CATEGORIAS } \\
\text { ANALÍTICAS }\end{array}$ & $\begin{array}{l}\text { CATEGORIAS } \\
\text { EMPÍRICAS }\end{array}$ & 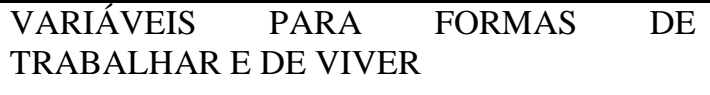 & $\begin{array}{l}\text { VARIÁVEIS } \\
\text { CORTE }\end{array}$ \\
\hline $\begin{array}{ll}\text { Processo } & \text { de } \\
\text { reprodução } & \\
\text { social } & \text { no } \\
\text { momento } & \text { da } \\
\text { produção } & \end{array}$ & $\begin{array}{l}\text { Formas } \\
\text { trabalhar }\end{array}$ & $\begin{array}{l}\text { inserção na produção (número de trabalhadores } \\
\text { na família/ local de trabalho/ atividade/ registro } \\
\text { em carteira profissional) } \\
\text { dispêndio de energia no trabalho (tempo de } \\
\text { locomoção para o trabalho/ dias-horas } \\
\text { trabalhados por semana) } \\
\text { direitos e benefícios do trabalho (salário } \\
\text { líquido de cada trabalhador/ número e tipo de } \\
\text { benefícios recebidos pelos trabalhadores na } \\
\text { família). }\end{array}$ & $\begin{array}{l}\text { renda familiar per capita } \\
\text { recebimento de } \\
\text { benefícios } \\
\text { registro em carteira } \\
\text { profissional }\end{array}$ \\
\hline $\begin{array}{ll}\text { Processo } & \text { de } \\
\text { reprodução } & \\
\text { social } & \text { no } \\
\text { momento } & \text { do } \\
\text { consumo } & \end{array}$ & form & $\begin{array}{l}\text { uso do espaço social (tempo de moradia em São } \\
\text { Paulo/procedência/tipo de habitação/ } \\
\text { propriedade da habitação/número de cômodos } \\
\text { para dormir); } \\
\text { infra-estrutura de habitação (número de } \\
\text { pessoas por cômodo/ localização do banheiro/ } \\
\text { uso coletivo ou não do banheiro/ propriedade de } \\
\text { eletrodomésticos/ condições de ventilação, } \\
\text { umidade, iluminação da habitação/ saneamento } \\
\text { básico - procedência da água, destino do esgoto } \\
\text { e do lixo); } \\
\text { dinâmica social da vida familiar ( riscos } \\
\text { percebidos oriundos das formas de viver/ } \\
\text { religião/ vida associativa - agregação social). }\end{array}$ & $\begin{array}{l}\text { Propriedade } \\
\text { habitação } \\
\text { exposição à riscos } \\
\text { agregação social }\end{array}$ \\
\hline
\end{tabular}

Fonte: Salum e Queiroz $(1997,2000,2010)$

Quadro 3 - Limites de exclusão/inclusão das variáveis de corte para formas de trabalhar, utilizados na operacionalização da heterogeneidade do coletivo segundo a inserção no momento da produção.

\begin{tabular}{|l|l|}
\hline $\begin{array}{l}\text { VARIÁVEIS DE CORTE PARA FORMAS DE } \\
\text { TRABALHAR }\end{array}$ & LIMITES DE EXCLUSÃO/INCLUSÃO \\
\hline Renda familiar per capita (RFPC) & $\begin{array}{l}\text { I - famílias com RFPC igual ou superior a 1,8 Salários } \\
\text { Mínimos } \\
\text { E - famílias com RFPC até 1,8 do Salários Mínimos }\end{array}$ \\
\hline Registro em carteira profissional & $\begin{array}{l}\text { I - famílias em que 1 ou mais membros são registrados em } \\
\text { carteira profissional; } \\
\text { E - famílias em que nenhum membro é registrado em carteira } \\
\text { profissional ou não está trabalhando no momento. }\end{array}$ \\
\hline Benefícios oriundos do trabalho & $\begin{array}{l}\text { I - famílias que usufruem de 2 benefícios oriundos do trabalho } \\
\text { de seus membros, sendo 1 deles relacionado à assistência à } \\
\text { saúde; } \\
\text { E - famílias que usufruem de um ou mais benefícios quaisquer } \\
\text { oriundos do trabalho de seus membros que não sejam } \\
\text { relacionados à assistência médica, ou que não usufruem de } \\
\text { qualquer benefício. }\end{array}$ \\
\hline
\end{tabular}

Fonte: Salum e Queiroz (1997, 2000, 2010) 
Quadro 4 - Limites de exclusão/inclusão das variáveis de corte para formas de viver, utilizados na operacionalização da heterogeneidade do coletivo segundo a inserção no momento do consumo.

\begin{tabular}{|l|l|}
\hline $\begin{array}{l}\text { VARIÁVEIS DE CORTE PARA FORMAS DE } \\
\text { VIVER }\end{array}$ & LIMITES DE EXCLUSÃO/INCLUSÃO \\
\hline Propriedade da habitação & $\begin{array}{l}\text { I - famílias que moram em casa própria; } \\
\text { E - famílias que moram em casa alugada, cedida ou } \\
\text { invadida. }\end{array}$ \\
\hline Exposição a riscos oriundos da forma de viver & $\begin{array}{l}\text { I - famílias que não se reconhecem expostas a riscos; } \\
\text { E - famílias que se reconhecem expostas a pelo menos 1 } \\
\text { risco. }\end{array}$ \\
\hline Agregação social & $\begin{array}{l}\text { I - famílias em que 1 ou mais membros participa de } \\
\text { grupos/ associações de naturezas diversas; } \\
\mathbf{E} \text { - famílias cujos membros não participam em grupos/ } \\
\text { associações de nenhuma natureza. }\end{array}$ \\
\hline
\end{tabular}

Fonte: Salum e Queiroz (1997, 2000, 2010)

Quadro 5 - Classificação das famílias estudadas em Grupos sociais homogêneos, segundo suas formas de trabalhar e de viver.

\begin{tabular}{|l|l|l|}
\hline $\begin{array}{l}\text { Formas de trabalhar } \\
\text { (FT) }\end{array}$ & Estáveis (FTE) & Instáveis (FTI) \\
\hline Formas de viver (FV) & $\begin{array}{l}\text { FTE/FVE } \\
\text { (GSH1) }\end{array}$ & $\begin{array}{l}\text { FTI/FVE } \\
\text { (GSH2) }\end{array}$ \\
\hline Instáveis (FVE) & $\begin{array}{l}\text { FTE/FVI } \\
\text { (GSH2) }\end{array}$ & $\begin{array}{l}\text { FTI/FVI } \\
\text { (GSH3) }\end{array}$ \\
\hline
\end{tabular}

Salum, Queiroz (2000) utilizaram a classificação em grupos sociais homogêneos e estudou os perfis de reprodução social e de desgaste de famílias da área de abrangência de um Centro de Saúde Escola de São Paulo. A autora verificou que nas famílias dos três grupos sociais os problemas respiratórios e dermatológicos foram os problemas agudos mais presentes. Os problemas respiratórios atingiram os plenamente incluídos (GSH1) com menor freqüência, os precariamente incluídos (GSH2) em freqüências intermediárias e os excluídos (GSH3) em frequiências maiores. Entre os plenamente incluídos e excluídos os problemas gástricos ocuparam o terceiro lugar em ordem de importância. Entre as famílias que compuseram o grupo precariamente incluído, os problemas que ocuparam o terceiro lugar foram os tensionais. Quanto aos problemas crônicos, os problemas circulatórios 
foram os que tiveram maior prevalência nos três grupos. $\mathrm{O}$ grupo dos plenamente incluídos apresentou em segundo lugar problemas endócrinos e ósteo-musculares. Os precariamente incluídos apresentaram os problemas alérgicos em segundo lugar. Esses problemas também ocuparam essa posição no grupo dos excluídos. Ressalta-se que as citações de problemas crônicos foram maiores no grupo dos excluídos. Assim identifica-se que os resultados do processo saúde-doença se distribuem de forma heterogênea nos três grupos sociais, o que deve ser tomado em consideração para o planejamento das intervenções em saúde.

Diversos outros trabalhos utilizaram a classificação em grupos sociais homogêneos com a finalidade de realizar a caracterização social das populações de estudo, entre eles os estudos de Biagolini (1999), Leite (1999), Santos (1999), Soares, Ávila, Salvetti (2000), Soares, Salvetti, Ávila, (2003), Laurenti (2005), Tamami (2007), Santos (2010) e Ribeiro (2011).

Analisando-se os dois mais recentes verificou-se que o trabalho de Santos (2010), foi delineado para analisar a dinâmica do processo educativo sobre fauna sinantrópica conduzido pelo Projeto Viver Bem com os Bichos, oferecido pelo Centro de Controle de Zoonoses de São Paulo. Foram avaliados os conteúdos apreendidos pelos multiplicadores bem como a atuação destes, de professores, alunos e responsáveis em uma instituição de ensino que passaram pelo processo educativo. Buscou-se estabelecer relações entre respostas e grupos sociais homogêneos. O autor identificou que existia correspondência entre os grupos sociais homogêneos onde estavam inseridos as famílias dos alunos e a submissão a riscos à saúde pelo contato com ratos e pombos. A análise feita com os grupos sociais homogêneos permitiu avaliar tendências de associações diferenciadas entre os GSH e as respostas citadas pelos responsáveis. Não houve impacto significativo do repasse de informações dos alunos aos seus responsáveis entretanto é importante ressaltar que, quando ocorria, este repasse variou nos grupos sociais homogêneos detectados e na condição de haver oportunidade de diálogo em casa.

Outro trabalho, o de Ribeiro (2011), buscou captar formas de trabalhar e de viver de moradores de um bairro de Manaus, que se originou de uma colônia de portadores de hanseníase. Os resultados mostraram discriminação e práticas excludentes a que os portadores de hanseníase eram submetidos pela sociedade, governo, família, equipe de saúde e administradores da colônia. Analisando as 
formas de viver dos doentes segregados, verificou-se relação entre o tratamento negligenciado e as conseqüências físicas e sociais graves que prejudicaram a autonomia dos indivíduos. O bairro apresentava graves deficiências em todos os serviços básicos de infraestrutura. A autora identificou que $77,8 \%$ das famílias apresentavam deficientes formas de trabalhar e de viver, ou seja, sua inserção social não lhes conferia estabilidade no momento da produção e do consumo.

Os dois trabalhos e os anteriores utilizaram o modelo de Salum e Queiroz (1997, 2000, 2010) em que as variáveis e os valores de corte utilizados para incluir uma família em um grupo social foram pré-determinados em função do aporte teórico utilizado e do estudo do comportamento dessas variáveis em estudos populacionais gerais. Assim, no trabalho das autoras e de outros que se seguiram, o que definiu as dimensões da produção e do consumo foi um conjunto de variáveis composto a partir da categoria teórica da reprodução social. Dessa forma, a comprovação empírica da capacidade das variáveis em diferenciar significativamente os grupos sociais nunca foi feita. Diante da pergunta "será que essas são as melhores variáveis para expor as diferenças entre os grupos sociais?" optou-se no presente trabalho por um estudo metodológico de base empírica que fornecesse as melhores variáveis.

Para tanto, além das variáveis utilizadas pelas autoras, foram testadas as tradicionalmente utilizadas pelos estudos epidemiológicos e outras captadas a partir da observação da realidade social. 
5. Pressuposto, objetivo e finalidade 


\section{5 - Pressuposto, objetivo e finalidade}

Diante da importância de se considerar a inserção de classe dos sujeitos estudos epidemiológicos críticos (Yonekura, 2011), acreditando na potencialidade da categoria reprodução social de reconhecer a heterogeneidade do território e as especificidades do micro espaço que dificilmente são captadas por meio de inquéritos populacionais abrangentes, este estudo tem como objetivo geral averiguar a capacidade das variáveis de trabalho e vida de mostrar as diferenças de reprodução social das famílias nos espaços do bairro e das ruas. Tem por finalidade embasar tanto o planejamento no âmbito do serviço de saúde quanto o planejamento de políticas públicas voltadas para os determinantes sociais do processo saúde-doença.

\subsection{Objetivos específicos}

- levantar por meio de inquérito domiciliar variáveis de reprodução social de famílias que vivem em diferentes espaços sociais de uma cidade da RMSP;

- analisar o comportamento dessas variáveis de reprodução social quanto à sua capacidade para formar grupos com semelhantes formas de trabalhar e de viver;

- construir um índice de reprodução social capaz de mostrar as diferenças de reprodução social entre as famílias no micro espaço (rua, setor censitário, bolsões de favela, ocupações de terrenos); 
6. Procedimentos Metodológicos 


\section{6- Procedimentos Metodológicos}

\section{1- Tipo de pesquisa}

Trata-se de um estudo de caráter metodológico, que valeu-se de um levantamento para a coleta de dados, cujo desenho pautou-se na elaboração e consecução de diversas etapas: 1) definição de variáveis empíricas que melhor representassem o conceito de reprodução social, tomado como central neste estudo; 2) elaboração do instrumento de coleta de dados, com posterior seleção da amostra; coleta, análise e interpretação dos dados; 3) construção do Índice de Reprodução Social.

\section{2- Caminho Percorrido}

\section{1) Definição das variáveis empíricas}

A fim de responder ao objetivo principal desse trabalho - averiguar a capacidade das variáveis de trabalho e vida de mostrar desigualdade de classe partiu-se de variáveis tradicionalmente utilizadas em trabalhos de epidemiologia bem como das variáveis utilizadas por Salum e Queiroz (1997, 2000, 2010) já apresentadas anteriormente para a conformação de grupos sociais homogêneos além de outras definidas a partir da observação da realidade:

Variáveis sócio-demográficas: sexo, religião, idade, cor/raça/etnia, local de nascimento

Variáveis das formas de trabalhar (dimensão da produção): escolaridade, condição de atividade, tempo gasto para ir/voltar do trabalho ou da escola, profissão, ocupação/função, setor de trabalho, onde trabalha, horas semanais trabalhadas, registro em carteira, curso preparatório para o trabalho, tempo de trabalho no mesmo emprego, renda no trabalho principal, rendas adicionais, benefícios advindos do trabalho, meio de transporte para ir/voltar do trabalho/escola.

Variáveis de formas de viver (dimensão do consumo): benefícios advindo de programas redistributivos ou de instituições da sociedade civil, material 
predominante na habitação, localização da habitação, propriedade da residência, pagamento de IPTU, tempo de moradia, motivo de mudança, bens no domicílio, acesso aos serviços públicos de água, de luz e de lixo, recebimento de conta de água, de luz e de esgoto, forma de coleta de lixo, riscos a que as pessoas da casa se sentem mais expostas, instituições do bairro que utiliza, participação social em grupo/associação/sindicato/partido político, suficiência da renda para arcar com os gastos (alimentação, vestuário, água e luz), posse de poupança por algum membro da família, gastos com crediários/empréstimos, dívidas que membros da família não conseguem pagar.

Dentre as variáveis de forma geral, a ocupação principal exercida pelo indivíduo tem peso muito elevado no processo de classificação social. As variáveis relacionadas às categorias ocupacionais vêm sendo tradicionalmente utilizadas nos estudos europeus desde metade do século XIX (Crompton, 1998; Elo, 2009). A conceituação e mensuração de classe social têm tradicionalmente sido baseadas na concepção weberiana de posição social hierárquica nos quais indivíduos de semelhantes posições compartilham chances de vida comuns (Crompton, 1998). Na Europa os estudos comumente salientam a estreita ligação entre colocação ocupacional e condições de saúde e mortalidade. Renda e níveis de escolaridade também são utilizados como medidas para capturar a combinação de características sociais e econômicas que são compartilhadas pelos indivíduos dentro da mesma categoria ocupacional (Elo, 2009). Tais estudos demonstram que a taxa de mortalidade é menor entre os indivíduos com ocupações mais qualificadas (Elo, 2009). Estudos ingleses demonstram que o risco de doenças cardiovasculares é maior entre trabalhadores da construção civil que estão em cargos com menor controle sobre o processo de trabalho, corroborando a hipótese de que a alienação do processo de trabalho está relacionado com uma grande carga de stress (Elo, 2009). A ocupação está relacionada à renda, à estabilidade no trabalho e aos benefícios oriundos do trabalho e tem sido eleita pelos pesquisadores uma das variáveis mais importantes no processo de classificação (Mattar, 1995; Crompton, 1998).

Nos Estados Unidos os estudos têm privilegiado variáveis de escolaridade, renda ou riqueza em adição ou em substituição a variáveis de ocupação (Elo, 2009). No que diz respeito à renda, Singer (1981) afirma que as estruturas de classe e de repartição da renda são congruentes. Como as relações de classe são relações de 
dominação e exploração, os que ocupam posições dominantes na estrutura de classes também usufruem de situações relacionados aos privilégios da renda.

A renda, a despeito de suas limitações como variável isolada, ainda mantém sua importância nos estudos epidemiológicos. Costa et al (2002), por exemplo, ao estudar a prevalência de agravos de saúde mental na cidade de Pelotas verificou que as pessoas com renda familiar inferior a três salários mínimos apresentaram duas a três vezes maior prevalência desses problemas em comparação com as pessoas com ganho maior que dez salários mínimos (Costa et al, 2002). Autores como Elo (2009) chamam a atenção para o fato de que a renda está relacionada com uma maior ou menor carga de "stress financeiro" e com a possibilidade de acesso aos serviços de saúde. Estudos norte-americanos e ingleses demonstraram significante associação entre renda e doenças crônicas em indivíduos adultos de meia idade (Elo, 2009). Por outro lado, a autora apresenta o ponto de vista de vários economistas que consideram que a educação tem um peso maior que a renda para explicar as diferenças sócioeconômicas em saúde, chamando a atenção para o fato de que renda e ocupação estão intimamente relacionadas com escolaridade.

Segundo Mattar (1995) a educação é especialmente importante para a classificação em grupos sociais, pois existe forte associação entre educação e renda. Elo (2009) chama a atenção para o fato de que a ascensão educacional é relevante para mensurar as classes sociais em estudos europeus. A autora ressalta que em países menos desenvolvidos pode ser difícil mensurar classes sociais diante de um leque muito grande de variáveis como renda, riqueza e ocupação e assim a ascensão educacional poderia se tornar então um indicador central. A relação entre escolaridade e processo saúde-doença foi verificada por diversos autores, entre eles Salles-Peres et al. (2002) que, ao analisar os determinantes sociais e biológicos da cárie dentária em crianças de 6 anos de idade, identificou que aquelas cujas mães estudaram 8 anos ou menos e cuja renda familiar foi menor que 6 salários mínimos tiveram maior risco de apresentar cárie.

Elo (2009) em seu estudo de revisão identificou que o nível de escolaridade se constitui em uma variável importante que apresenta correlação com índices de morbidade e mortalidade nos Estados Unidos e em países europeus, latinoamericanos e asiáticos. Ressaltando que nos dois últimos casos a correlação varia de acordo com o período e o país. A autora cita que nos Estados Unidos identificou-se 
que as doenças crônicas se desenvolvem de 5 a 15 anos mais tarde nos indivíduos com maior escolaridade. A autora aponta também para diversos estudos que verificaram a estreita relação entre nível de escolaridade materno e condições de saúde infantil. Por outro lado, a autora chama a atenção para o fato de que a educação como variável isolada não é responsável mudança da situação de saúde devendo ser consideradas outras questões como o acesso aos serviços, por exemplo.

Outras variáveis clássicas definidoras das condições de vida foram mantidas nesse trabalho entre elas as características da moradia das famílias e a presença de certos bens de consumo.

As características da moradia podem ser altamente discriminadoras da classificação social. A forma, o local, o tipo e o tamanho da residência apresentam alta correlação com a classificação em grupos sociais (Mattar, 1995). Para tanto têm sido utilizados número de cômodos, número de quartos e número de banheiros, bem como propriedade da moradia e número de pessoas que moram na mesma casa.

Por outro lado, Mattar (1995) aponta que a posse de bens de consumo isoladamente não é suficiente para classificar as famílias em determinadas classes sociais. Citando Rosenberg ele afirma que não há claras diferenças entre classes em termos de posse de itens de consumo. A burguesia não se diferencia do proletariado pelo fato de possuir um automóvel. Além disso, essas variáveis necessitam de estabilidade, não podendo estar muito frequentemente sujeitas a revisões e adaptações à realidade. Sendo assim, e tomando-se a devida cautela na utilização da posse de eletrodomésticos como variável, serão utilizados itens baseados em variáveis definidas pela ABIPEME em 2008.

Outras variáveis não comumente encontradas que caracterizam as condições de vida e que foram utilizadas por Salum e Queiroz (1997, 2000, 2010) foram também mantidas no presente trabalho devido à importância que vem assumindo nos estudos epidemiológicos. São elas a rede de apoio social e a percepção da população tanto em relação a problemas de infra-estrutura da casa e do bairro quanto em relação a situações como violência.

A rede de apoio social se constitui em potencial de fortalecimento das formas de viver. Alguns estudos chegaram a verificar a relação entre rede de apoio social e determinados agravos. Gandarillas et al (2005) afirmam que variáveis relacionadas a barreiras sociais como baixos níveis de controle social (Bosma \& Cols, 1997) e de 
apoio (Knox, 1993 e Krantz, 2002) podem estar diretamente associadas à hipertensão.

A exposição a riscos, entre eles a violência, também se constitui em potencial de desgaste das formas de viver e se distribui de forma diferenciada nos diversos grupos sociais. Gianini, Litvoc, Eluf Neto (1999) estudaram a relação entre agressão física e classe social operacionalizada segundo a classificação de Bronfman e Tuiram. Verificaram que o subproletariado, definido por indivíduos que desempenham atividades instáveis e com rendimentos inferiores ao custo mínimo da reprodução de força de trabalho, apresentaram risco aumentado de vitimização por agressão física.

Entre as adaptações feitas no instrumento originalmente proposto por Salum e Queiroz (1997, 2000, 2010), considerou-se importante ressaltar os aspectos abaixo relacionados. Ressalta-se que a família - tendo o chefe de família por referência foi escolhida como unidade de estudo pois cabe a ela uma dupla função na modernidade:

“ reproduzir em cada indivíduo (...) a ordem do mundo, ou seja, a dominação impessoal, que ultrapassa os limites da própria família; e ao mesmo tempo, dotar o indivíduo de um sentido prático da classe (...) ou seja, [de uma] capacidade de agir no mundo em compatibilidade com suas estruturas, antecipando essas estruturas e sobrevivendo a elas" (Souza, 2010.p. 128).

Sendo assim, destaca-se as seguintes observações em relação às variáveis:

\section{1) Formas de trabalhar}

a) Escolaridade: foram acrescentadas as denominações "completo" e "incompleto" para ensino fundamental, médio e superior com a finalidade de caracterizar melhor a escolaridade. Também foram acrescentados os itens "supletivos do ensino fundamental" e "supletivo do ensino médio" devido ao fato de que cada vez mais as exigências dos empregadores por maiores níveis de escolaridade tem se intensificado, obrigando os trabalhadores a completarem a formação no menor tempo possível.

b) Condição de atividade: essa variável foi conformada pela junção das variáveis "posição na ocupação" e "inserção no trabalho" do instrumento de Salum e Queiroz 
(1997, 2000, 2010) com a intenção de discriminar a posição que os membros da família ocupam no mundo do trabalho no que diz respeito à propriedade dos meios de produção (empregador, assalariado ou não inserido) bem como as subdivisões provenientes da realidade de trabalho informal (bico, trabalhador familiar, trabalho doméstico) e do desemprego.

c) Tempo no trabalho: essa variável foi incluída com a finalidade de identificar a estabilidade no emprego nos membros das famílias já que a instabilidade pode se constituir em potencial de desgaste nas formas de trabalhar dessas famílias.

d) Rendas adicionais: essa variável foi acrescentada devido ao fato de que muitas famílias recorrem a rendas adicionais de alguns de seus membros provenientes por exemplo de seguro-desemprego, auxílio do INSS, aluguel, programas sociais, entre outros, para promover o atendimento de suas necessidades.

e) Recebimento de benefícios oriundos do trabalho. Foram incluídas as variáveis "Vale supermercado" que se constitui em salário indireto oferecido atualmente por diversas empresas públicas ou privadas.

f) Qual o meio de transporte que utiliza normalmente para ir ao local de trabalho/escola? Essa variável foi acrescentada ao questionário com a intenção de discriminar os diferentes potenciais de desgaste das formas de trabalhar dos grupos sociais relacionados ao meio de transporte que as famílias utilizam para o trabalho .

g) Tempo gasto para ir ao trabalho/escola - Tempo gasto para voltar do trabalho (em minutos). Essa variável também foi somada com o objetivo de detectar os desgastes provenientes do tempo de locomoção da casa para o trabalho e vice-versa.

\section{2) Formas de viver}

a) Tipos de benefícios advindos de programas redistributivos ou de instituições da sociedade civil: esse indicador foi acrescentado por se constituir em potencial de 
fortalecimento das formas de viver ao se constituir na única fonte de subsistência de algumas famílias ou em complementação da renda principal.

b) Tipo de habitação: a localização das casas/apartamentos foi detalhada diferenciando-se as que pertencem a conjuntos residenciais populares das que não, devido ao fato de apresentarem diferentes condições de infraestrutura e serem acessadas por grupos sociais diversos. Acrescentou-se ainda a variável "casa de fundos" para definir uma casa que divide o terreno com outras. O material da casa na favela também foi acrescentado já que a moradia de madeira é muito mais precária que a de alvenaria, se constituindo em potencial de desgaste relacionado às formas de viver. O termo "cortiço" foi substituído por "cômodo" já que cortiço diz respeito a construções concentradas no centro deteriorado das cidades e a casa de cômodos representa muito mais a realidade das regiões periféricas.

c) Habitação com acabamento/sem acabamento: acrescentou-se a variável devido ao fato de que viver em casas sem acabamento resulta em desgastes que não estão presentes nas casas com acabamento.

d) Propriedade da residência: em relação a essa variável foi acrescentado o item casa "própria em terreno não próprio" já que tem sido cada vez mais comum a ocupação de áreas do estado por famílias que constroem suas casas e depois acabam por morar nelas definitivamente por meio de cartas de concessão ou não, chegando a comercializar o imóvel.

e) Paga IPTU: essa variável possibilita verificar em que condições as famílias vivem já que discrimina os isentos que estão nessa condição exatamente por possuírem moradias de baixo valor, muitas vezes relacionadas à precariedade de suas instalações.

f) Tempo de moradia na residência, motivo da mudança e de onde mudou: essas variáveis visam identificar a ocupação do espaço geossocial e os deslocamentos no sentido de captar os possíveis movimentos de mudança para regiões mais excluídas 
como consequência da precarização cada vez maior da inserção dos membros das famílias no mundo do trabalho.

g) Bens no domicílio: as variáveis aqui consideradas foram baseadas nas definidas pela ABIPEME em 2008 por apresentarem forte correlação com a renda. Foi acrescido o item computador.

h) Acesso aos serviços públicos acrescentou-se os itens "recebe conta desses serviços" com a intenção de diferenciar as instalações oficiais dos "gatos" mais presentes nas moradias dos grupos sociais mais excluídos. Também buscou-se detalhar a forma de coleta de lixo se em caçamba ou via pública. A forma de coleta em caçamba é mais comum em situações de favela em que as vielas não permitem a passagem de caminhões. As caçambas acabam ficando distantes das moradias e muitos moradores acabam por deixar o lixo nas próprias vielas onde ele se espalha e se torna fonte de contaminação atraindo inclusive vetores.

i) Riscos a que as pessoas da casa sentem-se mais expostas. Foi acrescido nesse indicador os itens "risco de consumo de drogas (inclusive alcoolismo)" e "envolvimento com problemas decorrentes do tráfico de drogas" com a intenção de distinguir o item "risco de drogas e alcoolismo" utilizado no questionário original.

j) Instituições da sociedade civil que utiliza no bairro: esse indicador foi somado ao questionário por fornecer informações a respeito das redes sociais de apoio complementando as informações obtidas com o indicador "participação em grupo/associação". Como discutido anteriormente, as redes sociais de apoio se constituem em potenciais de fortalecimentos das formas de viver.

1) Participação de grupo/ associação: foi acrescentado a participação em ONG.

m) As seguintes variáveis foram incluídas: suficiência da renda para arcar com os gastos com vestuário e alimentação, posse de poupança por algum membro da família, gastos com crediário, dívidas que não podem ser pagas. Essas variáveis 
foram somadas já que apenas o dado isolado da renda dos indivíduos não fornece informações suficientes sobre a possibilidade de reprodução social dessas famílias.

\section{2) Elaboração do instrumento de coleta de dados, seleção da amostra; coleta, análise e interpretação dos dados}

O instrumento (Anexo I) elaborado buscou contemplar o conjunto das variáveis de trabalho (dimensão do consumo) e de vida (dimensão da produção) e seu preenchimento foi orientado por um manual (Anexo II) e realizado por entrevistadores capacitados.

Para avaliar a capacidade das variáveis de diferenciar grupos sociais elas foram testadas em famílias de jovens do Município de Santo André.

Santo André integra o Grande ABC, parte da Região Metropolitana de São Paulo que se configura em região tradicionalmente industrial do Estado de São Paulo e se destacou no cenário nacional devido aos movimentos sindicais nas décadas de 1970 e 1980. A sigla vem das três cidades que originalmente formavam a região (Santo André, São Bernardo e São Caetano do Sul). Ao longo do tempo foram ocorrendo divisões geopolíticas e a incorporação de outras 4 cidades (Diadema, Mauá, Ribeirão Pires, Rio Grande da Serra). A cidade de Santo André possui uma população estimada de 676.407 habitantes (Instituto Brasileiro de Geografia e Estatística, 2010), conta com áreas rural e de mananciais.

Apresenta condições satisfatórias quanto aos índices de desigualdade $(0,816)$, pobreza $(0,816)$, analfabetismo $(0,921)$ se considerarmos os indicadores de exclusão social formulados por Pochmann, Amorim (2003) para se demonstrar a qualidade de vida dos moradores das cidades ${ }^{7}$.

\footnotetext{
${ }^{7}$ A condição social considerada ideal se aproxima do índice 1 e a mais grave condição tende ao 0.
} 
Outros indicadores já apresentam valores menores como escolaridade $(0,754)$, violência $(0,792)$ e principalmente emprego formal $(0,209)$.

Segundo o Censo feito em 2000, existiam 121.814 jovens em Santo André com idade entre 15-24 anos (Instituto Brasileiro de Geografia e Estatística, 2010). Desde a década de 1970, o município juntamente com as demais cidades do ABC, vem desenvolvendo projetos voltados para os jovens o que o destaca no cenário nacional. Para além dos projetos voltados à proteção social o município vem incentivando no espaço público o desenvolvimento de programas culturais e de lazer (Almeida, Villar, 2005).

Desde o início da década de 90, foram contabilizados mais de uma centena de projetos voltados ao segmento juvenil, na região do grande $\mathrm{ABC}$, mais da metade concentrados em Santo André e São Caetano. Em 1997, houve uma sinalização no cenário político de maior compromisso com os problemas da juventude, com a aprovação da lei nº 7.469/97 para cumprir a função de instância assessora e executora de ações voltadas à diversidade do mundo juvenil. Essa assessoria ocupou várias secretarias até ser extinta em 2004 (Almeida, Villar, 2005). Na atual gestão, nenhuma secretaria ou assessoria de juventude é prevista.

O presente estudo voltou-se para famílias de jovens em Santo André pois deriva do estudo matriz "Jovens, valores e consumo de drogas: políticas públicas na perspectiva da saúde coletiva" desenvolvido nesse município e que num primeiro momento construiu o Mapa das Juventudes de Santo André (Yonekura et al, 2010). A faixa etária escolhida foi de 15 a 24 anos, convencionada no Brasil como juventude (Frigotto, 2004). Tal recurso mostrou as diferenças sociais entre os jovens moradores do município e serviu de apoio para decisões de caráter metodológico do presente trabalho e de outras investigações. Resultou em uma representação gráfica que dividiu os jovens em quatro grupos sociais (Anexo III).

O processo de construção do mapa iniciou-se com a captação de dados secundários obtidos do Censo de 2000/IBGE e identificação de variáveis representativas de condições de trabalho e vida dos jovens que se distribuíam pelas 43 REDES de Santo André (Regiões de Dados Estatísticos - um recorte do território em distritos menores utilizadas para planejamento da gestão municipal). Por meio de procedimentos estatísticos realizaram-se possíveis agregações de REDES discriminadas pelas variáveis. 
Para a definição dos quatro grupos, inicialmente, selecionou-se um conjunto de 57 indicadores sócio-demográficos e econômicos relativos à reprodução social de jovens (15-24 anos) a partir do Censo demográfico de 2000/IBGE. Os dados se referiam a: características gerais, migração, instrução, nupcialidade, fecundidade, trabalho e rendimento, características domiciliares e de saneamento, e potencial de consumo (Yonekura et al, 2010).

As variáveis correspondentes aos 57 indicadores foram distribuídas por REDE - Regiões de Dados Estatísticos (tendo por referência as 19 Regiões de Orçamento Participativo e os 117 bairros da cidade).

Alguns indicadores foram pré-selecionados e submetidos à análise fatorial utilizando-se o software Statistical Package of Social Scienses (2004). A análise mostrou que, desse conjunto, 13 foram as variáveis que mais discriminaram estatisticamente as REDES entre si, colocando dessa forma em evidência as desigualdades sociais entre os jovens (Yonekura et al, 2010).

As treze variáveis foram: Não nasceu na UF (ter nascido fora do estado de São Paulo); Frequenta escola - ensino Fundamental (encontra-se frequentando o ensino fundamental); Curso mais elevado que concluiu: ensino Fundamental; Frequenta escola - ensino Médio (encontra-se freqüentando o ensino Médio); Ensino: Não Superior (não tem o nível superior, ainda que esteja na idade para tal); Trabalho remunerado: Não (não está trabalhando); Posição do jovem no Domicílio: Jovem responsável pelo domicílio; Presença de Cônjuge ou companheiro - Sim - vive com companheiro; Número de filhos: 2 filhos; Densidade de moradores por dormitório: mais de 3; condição de ocupação do terreno: cedido ou outra; Esgoto: Fossa Séptica (o esgotamento sanitário é feito por meio de fossa séptica); Quantidade de automóveis: zero (não ter automóvel) (Yonekura et al, 2010).

Assim, essas variáveis representam um conjunto de indicadores capaz de identificar múltiplas dimensões da reprodução social, pois dizem respeito a um leque de aspectos que inicia-se na procedência, passa por escolaridade, chega ao trabalho e à responsabilidade pela família e vai até as condições de consumo e serviços de infra-estrutura urbana (Yonekura et al, 2010).

Foram obtidos 2 fatores que explicaram $77 \%$ da variância total dos dados por meio do método de extração utilizado que envolveu análise de componentes principais (Yonekura et al, 2010). 
Após a análise inicial, realizou-se um agrupamento que subsidiou a obtenção de 4 grupos sociais. O grupo de REDES - que concentrava os jovens com mais acesso à riqueza foi classificado como Central (C) e o que concentrava os jovens com menos acesso como Periférico $(\mathrm{P})$. Ressalta-se que a distribuição das riquezas coincidiu com a localização geográfica dos grupos verificando-se que conforme a exclusão social aumentava nos grupos eles se localizavam mais distantes do centro do município, o que justifica a terminologia adotada. Entre esses extremos, duas gradações puderam ser identificadas, uma mais próxima ao extremo do acesso - a Quase Central $(\mathrm{QC})$ - e outra mais próxima à privação - a Quase Periférica $(\mathrm{QP})$. Como pode ser verificado no Anexo III (Yonekura et al, 2010).

A partir do Mapa das Juventudes decidiu-se selecionar uma amostra das famílias de jovens que contemplasse a heterogeneidade das características sociais dos quatro agrupamentos com o objetivo de testar as variáveis.

Pretendia-se com a identificação dos jovens se chegar às famílias. Assim, a próxima etapa consistiu na definição das instituições freqüentadas por esses jovens para a aplicação dos questionários. Optou-se por uma amostra proporcional ao número total de jovens distribuídos nos quatro grupos de acordo com dados do IBGE.

As instituições selecionadas foram escolhidas entre as indicadas por trabalhadores da Secretaria de Saúde de Santo André e que aceitaram participar da pesquisa. Foram escolhidas escolas estaduais com jovens de 15 a 18 anos e outras instituições como clubes e escolas com cursos técnicos para os jovens de 19 a 24 anos (Quadro 6). 
Quadro 6 - Instituições em que se realizaram a coleta de dados. Santo André, SP, 2008 .

\begin{tabular}{|l|l|}
\hline Grupo & Instituições \\
\hline Central & Colégio Singular, Colégio Arbus, Clube $1^{\text {}}$. De Maio \\
\hline Quase central & EE Celso Gama, EE Amaral Wagner, Clube Jaçatuba \\
\hline Quase periférico & $\begin{array}{l}\text { EE Parque Marajoara II, Centro Público de Formação } \\
\text { Profissional Júlio de Grammont, EE Beneraldo Toledo } \\
\text { Piza, EE Padre Aguinaldo Sebastião Vieira }\end{array}$ \\
\hline Periférico & $\begin{array}{l}\text { EE Francisca Helena Furia II, EE Waldemar Mattei, EE } \\
\text { Nelson Pizzotti Mendes, Parque Adreense }\end{array}$ \\
\hline
\end{tabular}

Os jovens estavam assim distribuídos nos quatro grupos sociais (Quadro 7):

Quadro 7- Distribuição dos jovens de 15 a 24 anos nos quatro grupos sociais originais.

\begin{tabular}{|l|l|l|l|l|}
\hline GRUPOS & $\begin{array}{l}\text { No. de } \\
\text { redes } \\
\text { por } \\
\text { grupo }\end{array}$ & $\begin{array}{l}\text { População Total } \\
\text { Jovens* }\end{array}$ & $\begin{array}{l}\text { Número de } \\
\text { redes } \\
\text { escolhidas por } \\
\text { grupo }\end{array}$ & $\begin{array}{l}\text { População jovem } \\
\text { das redes } \\
\text { escolhidas }\end{array}$ \\
\hline $\begin{array}{l}\text { Grupo } \\
\text { Central }\end{array}$ & 4 & 8773 & 2 & 2.024 \\
\hline $\begin{array}{l}\text { Grupo } \\
\text { Quase } \\
\text { Central }\end{array}$ & 10 & 25528 & & \\
\hline $\begin{array}{l}\text { Grupo } \\
\text { Quase } \\
\text { Periférico }\end{array}$ & 19 & & 3 & 5.484 \\
\hline $\begin{array}{l}\text { Grupo } \\
\text { Periférico }\end{array}$ & 10 & 34564 & & 13.293 \\
\hline \multicolumn{1}{|c|}{ Total } & $\mathbf{4 3}$ & $\mathbf{1 2 1 . 8 1 4}$ & $\mathbf{2 1}$ & 11.105 \\
\hline
\end{tabular}

* IBGE 2000

Por meio de amostragem estratificada e de modo a se trabalhar com a proporcionalidade dos jovens de cada grupo social, a amostra final foi assim definida como se apresenta no quadro 8. Optou-se por considerar um erro absoluto de $1,5 \%$ pois uma margem de erro menor incorreria no aumento da amostra obstaculizando a coleta de dados. 
Quadro 8- Amostra planejada e distribuída nos quatro grupos sociais originais.

\begin{tabular}{|l|c|}
\hline \multicolumn{2}{|c|}{ Amostra planejada* } \\
\hline GRUPOS & $\begin{array}{l}\text { Número de jovens } \\
\text { por grupo social }\end{array}$ \\
\hline Central & 38 \\
\hline Quase-central & 100 \\
\hline Quase-periférico & 240 \\
\hline Periférico & 200 \\
\hline Total & 578 \\
\hline
\end{tabular}

*erro absoluto de $1,5 \%$.

Ressalta-se que o cálculo da amostra foi somente o ponto de partida para que fosse possível obter famílias de grupos sociais diferentes de forma a possibilitar o teste das variáveis. Partiu-se, assim, de uma amostragem calculada a partir de dados secundários de um censo demográfico nacional apropriado para olhar grandes populações para se obter variáveis, que ao serem aplicadas, demonstrassem as diversidades de reprodução social no micro espaço.

Após a coleta de dados, ressaltando-se que no caso dos jovens menores de 18 anos os pais ou responsáveis responderam os questionários, foi produzido um banco de dados. Não houveram perdas e nenhum questionários precisou ser descartado. Diante da falta de alguma informação, já que o questionário diversas vezes foi aplicado em jovens que nem sempre sabiam responder a todas as questões sobre sua família, realizavam-se diversas tentativas de contatos telefônicos para completar os dados. Na sequiência foram cruzadas as informações obtidas junto aos jovens do estudo segundo local de moradia (Anexo IV).

Em uma segunda etapa com a finalidade de descrever o conjunto das famílias tendo o chefe da família como representante, foram processadas as informações obtidas sem que se discriminassem os grupos sociais (Anexo V). Assim, verificou-se o comportamento das variáveis no conjunto das famílias.

Para se estudar a família é necessário eleger um elemento de referência cuja posição na formação de classe possa representá-la em seu conjunto considerando-se que todos membros estão interligados (Office for National Statistics, 2005). O chefe 
de família pode ser o proprietário da moradia ou o responsável pelo aluguel e acomodação ou ainda o indivíduo que tiver a maior renda. Se houver igualdade de renda, considera-se a pessoa mais velha (Office for National Statistics, 2005). O presente estudo elegeu como chefe de família a pessoa referida pelo entrevistado.

Para definição das variáveis que discriminassem os grupos foram realizados diversos testes estatísticos, entre eles o procedimento Decision Trees- Árvores de Decisão. Esse teste não se mostrou apropriado para os objetivos do estudo, pois demonstrava como todas as variáveis se comportavam hierarquicamente em relação a uma variável fixa sem possibilitar a compreensão da relação entre as variáveis.

Decidiu-se então submeter as variáveis à análise fatorial utilizando-se o software Statistical Package of Social Scienses, versão 17,0 (SPSS, 2004). Optou-se pela análise fatorial pois a obtenção de fatores leva à redução do número de variáveis com as quais se pretende trabalhar facilitando o conhecimento a respeito de quais variáveis se destacam mais (Pestana e Gageiro, 2000).

A análise mostrou que, do conjunto, a dimensão da produção foi definida por dois fatores compostos por variáveis relacionadas ao chefe de família que explicaram cerca de $64 \%$ da variabilidade dos dados.

Ressalta-se que foram escolhidas as variáveis que tinham comunalidade (variância de cada variável) maior que 0,5 - preferível maior que 0,6. Cada variável com comunalidade menor que 0,5 foi excluída e submetida novamente ao modelo para a melhor adequação até a obtenção dos fatores. Destaca-se que foram considerados os eigenvalues maiores ou iguais a 1,0 .

Assim, a análise sugeriu as seguintes variáveis da dimensão da produção relacionadas ao chefe de família: registro em carteira, escolaridade, qualificação da ocupação, condição de atividade, curso preparatório para o trabalho. A variável renda foi excluída do teste devido à dificuldade de obtenção desse dado tanto no que diz respeito à relutância dos entrevistados em fornecer o valor quanto em relação à precisão do dado obtido.

A dimensão das formas de viver foi definida por quatro fatores compostos por variáveis relacionadas à família como um todo que explicaram cerca de $65 \%$ da variabilidade dos dados. Assim, a análise sugeriu as seguintes variáveis relacionadas à família como um todo: propriedade da residência, número de cômodos para dormir, pagamento de IPTU, acesso a serviço público de água, luz e esgoto, 
legalidade do acesso à água, luz e esgoto, grupos ligados à igreja como instituição freqüentada no território e culto como atividade de lazer.

Verifica-se que as variáveis sócio-demográficas não compuseram o conjunto de variáveis definidas por meio da análise. Podem ser então consideradas como qualificadores das dimensões da produção e do consumo o que está de acordo com o referencial utilizado no presente estudo e no qual questões de raça, gênero, entre outras são subsumidas à inserção do sujeito na sociedade. Assim, se as mulheres apresentam salários mais baixos que os homens o quadro é mais excludente nas mulheres dos grupos menos incluídos (Pochmann, 2006). Se entre os negros o desemprego é maior, ocorre variação segundo os grupos sociais no qual eles estão inseridos (Pochmann, 2006).

Dessa forma, as variáveis da dimensão do trabalho e da vida testadas nas famílias dos jovens dos quatro grupos sociais originais (Central, Quase Central, Quase Periférico e Periférico) se mostraram capazes de diferenciar tais grupos.

Essas variáveis sugeridas pela análise fatorial foram então submetidas à análise de agrupamentos via técnica Twostep (SPSS versão 17.0) com a finalidade de reclassificar as famílias dos jovens tendo por referência os chefes de família gerando assim novos grupos sociais,

A análise de agrupamentos classifica elementos (indivíduos, empresas, produtos ou mesmo comportamentos), de modo que cada elemento é muito semelhante aos outros no grupo em relação a um critério pré-determinado. Os agrupamentos resultantes dessa classificação devem conter elementos que exibam elevada homogeneidade interna dentro dos grupos e alto grau de heterogeneidade externa. Desta forma, se a classificação for bem sucedida, os objetos dentro dos agrupamentos estarão próximos entre si, e os objetos de diferentes agrupamentos estarão distantes entre si (Hair, Anderson, Tatham, Black, 1998).

A análise de agrupamentos visa reunir não mais as variáveis conforme ocorre na análise fatorial, mas sim os indivíduos/elementos observacionais. Esse método permite identificar uma estrutura de agrupamentos fornecendo assim interessantes hipóteses acerca de associações (Johnson e Wichern, 1992, p. 573).

A partir dos quatro novos grupos sociais - denominados I, II, III, IV - fez-se uso de outra técnica multivariada, a análise discriminante, que avalia a relação entre a variável dependente qualitativa (grupos) com as demais variáveis independentes, 
possibilitando determinar quais variáveis foram importantes na construção dos agrupamentos, ou seja, que diferenciam ou discriminaram os grupos, permitindo a identificação de grupos similares e a classificação de novos casos, onde a inserção é feita no grupo que o caso tem maior probabilidade de pertencer.

A análise discriminante valida a análise de agrupamento (cluster) (Pestana e Gageiro, 2000). Por meio de combinações lineares de variáveis independentes que melhor discriminam os grupos (variável dependente qualitativa) são definidas as regras de classificação dos elementos em cada grupo. Tal análise busca assim o grau de concordância entre a classificação ideal e os grupos obtidos, gerando também funções de classificação. Assim, identificou-se qual o grau de importância de cada uma das variáveis em comparação com o conjunto no que diz respeito à capacidade de diferenciar as famílias possibilitando sua classificação em um dos quatro grupos heterogêneos entre si mas homogêneos em seu interior.

\section{3) Construção do índice de reprodução social}

As variáveis de trabalho definidas que se destacaram na formação dos quatro grupos compuseram a dimensão da produção e as variáveis de vida configuraram a dimensão do consumo. A agregação das duas dimensões resultou no Índice de Reprodução Social (IRS) e seu processo de construção será apresentado no item 7.5 dos resultados.

\subsection{Aspectos éticos}

O projeto foi aprovado pelo Comitê de Ética em Pesquisa da Escola de Enfermagem da USP e da Secretaria Municipal da Saúde de Santo André. Os participantes foram convidados a assinar uma autorização por meio de um Termo de Consentimento Livre e Esclarecido elaborado de acordo com as normas da resolução 196/96 do Conselho Nacional de Saúde (Anexo VI).

Os jovens que tinham mais de 18 anos assinaram o consentimento e responderam os questionários e os menores tiveram seus pais contatados para assinar o termo e responder os questionários. Ressalta-se que os objetivos e a finalidade da 
pesquisa foram apresentados para cada entrevistado bem como para os coordenadores das instituições que participaram do estudo. 


\section{Resultados}




\section{7- Resultados}

Serão apresentadas as frequiências das variáveis identificadas e as distribuições nos quatro novos grupos sociais formados a partir da análise de agrupamentos .

Foram entrevistadas 589 famílias totalizando 2463 indivíduos. Foram acrescentadas 11 famílias na amostra original para cobrir possíveis perdas.

\section{1- Comparação entre os grupos originais e os grupos novos: capacidade} das variáveis de reprodução social de captar especificidades do micro espaço.

A partir dos quadros abaixo se verifica que a distribuição das famílias nos grupos originais (tabela 1) e nos grupos novos (tabela 2) se mostrou diferente. Ressalta-se que nos grupos originais o Grupo Central é o mais incluído e o Grupo Periférico se constitui no mais excluído. Nos grupos novos o mais incluído é o Grupo I e o mais excluído é o grupo IV.

Tabela 1- Distribuição das famílias nos quatro grupos sociais originais gerados a partir de dados secundários do IBGE. Santo André, SP, 2008

\begin{tabular}{lcc}
\hline Grupos Originais & N & \% \\
\hline Central & 26 & 4,4 \\
Quase central & 85 & 14,4 \\
Quase periférico & 249 & 42,3 \\
Periférico & 229 & 38,9 \\
Total & $\mathbf{5 8 9}$ & $\mathbf{1 0 0 , 0}$ \\
\hline
\end{tabular}

Tabela 2- Distribuição das famílias nos quatro novos grupos sociais gerados a partir das variáveis de formas de trabalhar e de viver. Santo André, SP, 2010.

\begin{tabular}{lcc}
\hline Grupos Novos & N & \% \\
\hline I & 143 & 24,3 \\
II & 250 & 42,4 \\
III & 102 & 17,3 \\
IV & 94 & 16,0 \\
Total & $\mathbf{5 8 9}$ & $\mathbf{1 0 0 , 0}$ \\
\hline
\end{tabular}

Nota: técnica utilizada na geração dos grupos: Twostep Cluster 
Os grupos novos gerados a partir das dimensões de produção e consumo, representaram de forma mais real as diversidades do microespaço, em comparação aos grupos originais classificados por meio de dados do IBGE no âmbito macroestrutural que deu origem ao Mapa da Juventude de Santo André (Yonekura, 2011). Esperava-se, por exemplo, que o grupo I se concentrasse nos bairros mais centrais o que não ocorreu. Ressalta-se que na nova distribuição existem mais famílias no grupo mais incluído.

Sendo assim, verificou-se que em cada bairro havia famílias de mais de um grupo social. Na tabela 3 apresenta-se a distribuição dos grupos sociais pelos bairros de Santo André. Observa-se por exemplo que a maior porcentagem das famílias dos grupos I, II e III encontrava-se no Pq. Capuava. Ressalta-se também que o grupo social I mostrou maior mobilidade pelo território enquanto que grupo social IV se apresentou concentrado na área mais excluída representada pelo bairro Recreio da Borda do Campo, que fica na área de mananciais de Santo André.

Tabela 3- Distribuição das famílias dos quatro novos grupos sociais pelos bairros classificados segundo sua posição no território. Santo André, SP, 2010.

(continua)

\begin{tabular}{|c|c|c|c|c|c|c|c|c|c|}
\hline \multirow{3}{*}{$\begin{array}{l}\text { POSIÇÃO NO } \\
\text { TERRITÓRIO }\end{array}$} & \multirow[t]{3}{*}{ BAIRROS } & \multicolumn{8}{|c|}{ GRUPOS } \\
\hline & & \multicolumn{2}{|c|}{ GRUPO I } & \multicolumn{2}{|c|}{ GRUPO II } & \multicolumn{2}{|c|}{ GRUPO III } & \multicolumn{2}{|c|}{ GRUPO IV } \\
\hline & & $\mathbf{N}$ & $\%$ & $\mathbf{N}$ & $\%$ & $\mathbf{N}$ & $\%$ & $\mathbf{N}$ & $\%$ \\
\hline \multirow[t]{9}{*}{ CENTRAL } & CAMPESTRE & 4 & 2,8 & 2 & 0,8 & 0 & 0,0 & 0 & 0,0 \\
\hline & JARDIM & 6 & 4,2 & 0 & 0,0 & 0 & 0,0 & 0 & 0,0 \\
\hline & CENTRO & 5 & 3,5 & 1 & 0,4 & 0 & 0,0 & 0 & 0,0 \\
\hline & JD. BELA VISTA & & & & & & & & \\
\hline & & 1 & 0,7 & 1 & 0,4 & 0 & 0,0 & 0 & 0,0 \\
\hline & VL. GILDA & 1 & 0,7 & 0 & 0,0 & 0 & 0,0 & 0 & 0,0 \\
\hline & CASA BRANCA & 0 & 0,0 & 2 & 0,8 & 0 & 0,0 & 0 & 0,0 \\
\hline & SANTA MARIA & 2 & 1,4 & 0 & 0,0 & 0 & 0,0 & 0 & 0,0 \\
\hline & VL. BASTOS & 1 & 0,7 & 0 & 0,0 & 0 & 0,0 & 0 & 0,0 \\
\hline \multicolumn{10}{|l|}{ QUASE CENTRAL } \\
\hline & PQ. ORATORIO & 3 & 2,1 & 0 & 0,0 & 1 & 1,0 & 0 & 0,0 \\
\hline & BANGU & 3 & 2,1 & 4 & 1,6 & 1 & 1,0 & 0 & 0,0 \\
\hline & VL. CURUCA & 7 & 4,9 & 2 & 0,8 & 2 & 2,0 & 0 & 0,0 \\
\hline & PQ. JACATUBA & 7 & 4,9 & 4 & 1,6 & 2 & 2,0 & 0 & 0,0 \\
\hline & VL. VALPARAISO & 3 & 2,1 & 6 & 2,4 & 3 & 2,9 & 0 & 0,0 \\
\hline & VL. SCARPELLI & 2 & 1,4 & 1 & 0,4 & 0 & 0,0 & 0 & 0,0 \\
\hline & PINHEIRINHO & 1 & 0,7 & 0 & 0,0 & 0 & 0,0 & 0 & 0,0 \\
\hline & VL. ASSUNCAO & 3 & 2,1 & 7 & 2,8 & 7 & 6,9 & 1 & 1,1 \\
\hline
\end{tabular}


Tabela 3- Distribuição das famílias dos quatro novos grupos sociais pelos bairros classificados segundo sua posição no território. Santo André, SP, 2010.

(continuação)

\begin{tabular}{|c|c|c|c|c|c|c|c|c|c|}
\hline \multirow{3}{*}{$\begin{array}{l}\text { POSIÇÃO NO } \\
\text { TERRITÓRIO }\end{array}$} & \multirow[t]{3}{*}{ BAIRROS } & \multicolumn{8}{|c|}{ GRUPOS } \\
\hline & & \multicolumn{2}{|c|}{ GRUPO I } & \multicolumn{2}{|c|}{ GRUPO II } & \multicolumn{2}{|c|}{ GRUPO III } & \multicolumn{2}{|c|}{ GRUPO IV } \\
\hline & & $\mathbf{N}$ & $\%$ & $\mathbf{N}$ & $\%$ & $\mathbf{N}$ & $\%$ & $\mathbf{N}$ & $\%$ \\
\hline & VL. ALZIRA & 1 & 0,7 & 2 & 0,8 & 1 & 1,0 & 0 & 0,0 \\
\hline & VL. HOMERO THON & 2 & 1,4 & 0 & 0,0 & 0 & 0,0 & 0 & 0,0 \\
\hline \multirow[t]{4}{*}{ QUASE CENTRAL } & VL AMÉRICA & 0 & 0,0 & 2 & 0,8 & 0 & 0,0 & 0 & 0,0 \\
\hline & SILVEIRA & 1 & 0,7 & 0 & 0,0 & 0 & 0,0 & 0 & 0,0 \\
\hline & VL. GUARANI & 1 & 0,7 & 0 & 0,0 & 1 & 1,0 & 0 & 0,0 \\
\hline & VL. PIRES & 1 & 0,7 & 2 & 0,8 & 0 & 0,0 & 1 & 1,1 \\
\hline \multicolumn{10}{|l|}{$\begin{array}{l}\text { QUASE } \\
\text { PERIFÉRICO }\end{array}$} \\
\hline & VL. MATALURGICA & 0 & 0,0 & 3 & 1,2 & 0 & 0,0 & 1 & 1,1 \\
\hline & VL. CAMILOPOLIS & 1 & 0,7 & 0 & 0,0 & 1 & 1,0 & 0 & 0,0 \\
\hline & JD. UTINGA & 0 & 0,0 & 0 & 0,0 & 1 & 1,0 & 0 & 0,0 \\
\hline & JD. SANTO ANTONIO & 1 & 0,7 & 4 & 1,6 & 0 & 0,0 & 0 & 0,0 \\
\hline & JD. ITAPOAN & 1 & 0,7 & 1 & 0,4 & 0 & 0,0 & 0 & 0,0 \\
\hline & VL. LUCINDA & 1 & 0,7 & 0 & 0,0 & 0 & 0,0 & 0 & 0,0 \\
\hline & $\begin{array}{l}\text { VL. FRANCISCO } \\
\text { MATARAZZO }\end{array}$ & 2 & 1,4 & 2 & 0,8 & 0 & 0,0 & 0 & 0,0 \\
\hline & PQ. NOVO ORATORIO & 1 & 0,7 & 1 & 0,4 & 1 & 1,0 & 0 & 0,0 \\
\hline & JD. ANA MARIA & 1 & 0,7 & 2 & 0,8 & 2 & 2,0 & 0 & 0,0 \\
\hline & PQ. DAS NAÇÕES & 0 & 0,0 & 4 & 1,6 & 1 & 1,0 & 0 & 0,0 \\
\hline & PQ. ERASMO ASSUNCAO & 6 & 4,2 & 15 & 6,0 & 5 & 4,9 & 1 & 1,1 \\
\hline & PQ. JOAO RAMALHO & 2 & 1,4 & 15 & 6,0 & 5 & 4,9 & 2 & 2,1 \\
\hline & PQ. CAPUAVA & 17 & 11,9 & 41 & 16,4 & 25 & 24,5 & 3 & 3,2 \\
\hline & VL. GUIOMAR & 1 & 0,7 & 1 & 0,4 & 1 & 1,0 & 1 & 1,1 \\
\hline & VL. ALICE & 3 & 2,1 & 1 & 0,4 & 0 & 0,0 & 0 & 0,0 \\
\hline & PARAÍSO & 0 & 0,0 & 1 & 0,4 & 1 & 1,0 & 0 & 0,0 \\
\hline & JD. STELLA & 1 & 0,7 & 3 & 1,2 & 0 & 0,0 & 0 & 0,0 \\
\hline & JD. JAMAICA & 0 & 0,0 & 0 & 0,0 & 1 & 1,0 & 0 & 0,0 \\
\hline & JD. ORIENTAL & 0 & 0,0 & 0 & 0,0 & 0 & 0,0 & 1 & 1,1 \\
\hline & JD. CRISTIANE & 0 & 0,0 & 2 & 0,8 & 0 & 0,0 & 1 & 1,1 \\
\hline & JD. ALVORADA & 0 & 0,0 & 1 & 0,4 & 0 & 0,0 & 0 & 0,0 \\
\hline & VL. LINDA & 2 & 1,4 & 0 & 0,0 & 2 & 2,0 & 1 & 1,1 \\
\hline & VL. MARINA & 0 & 0,0 & 1 & 0,4 & 1 & 1,0 & 0 & 0,0 \\
\hline & JD. DO ESTÁDIO & 0 & 0,0 & 4 & 1,6 & 0 & 0,0 & 0 & 0,0 \\
\hline & PQ. MARAJOARA & 10 & 7,0 & 9 & 3,6 & 8 & 7,8 & 1 & 1,1 \\
\hline & VL. HUMAITÁ & 0 & 0,7 & 2 & 0,8 & 0 & 0,0 & 0 & 0,0 \\
\hline & JD. IPANEMA & 1 & 0,7 & 0 & 0,0 & 0 & 0,0 & 0 & 0,0 \\
\hline & VL.SUICA & 0 & 0,0 & 5 & 2,0 & 0 & 0,0 & 2 & 2,1 \\
\hline & CENTREVILE & 2 & 1,4 & 0 & 0,0 & 0 & 0,0 & 2 & 2,1 \\
\hline & JD. MAREK & 1 & 0,7 & 4 & 1,6 & 2 & 2,0 & 0 & 0,0 \\
\hline
\end{tabular}


Tabela 3- Distribuição das famílias dos quatro novos grupos sociais pelos bairros classificados segundo sua posição no território. Santo André, SP, 2010.

(conclusão)

\begin{tabular}{|c|c|c|c|c|c|c|c|c|c|}
\hline \multirow{3}{*}{$\begin{array}{l}\text { POSIÇÃO NO } \\
\text { TERRITÓRIO }\end{array}$} & \multirow[t]{3}{*}{ BAIRROS } & \multicolumn{8}{|c|}{ GRUPOS } \\
\hline & & \multicolumn{2}{|c|}{ GRUPO I } & \multicolumn{2}{|c|}{ GRUPO II } & \multicolumn{2}{|c|}{ GRUPO III } & \multicolumn{2}{|c|}{ GRUPO IV } \\
\hline & & $\mathbf{N}$ & $\%$ & $\mathbf{N}$ & $\%$ & $\mathbf{N}$ & $\%$ & $\mathbf{N}$ & $\%$ \\
\hline \multicolumn{10}{|l|}{ PERIFÉRICO } \\
\hline & CIDADE SÃO JORGE & 8 & 5,6 & 15 & 6,0 & 5 & 4,9 & 1 & 1,1 \\
\hline & CONDOMINIO MARACANA & 7 & 4,9 & 25 & 10,0 & 8 & 7,8 & 12 & 12,8 \\
\hline & JD. ALZIRA FRANCO & 6 & 4,2 & 14 & 5,6 & 3 & 2,9 & 0 & 0,0 \\
\hline & JD. CLUBE DE CAMPO & 0 & 0,0 & 0 & 0,0 & 0 & 0,0 & 2 & 2,1 \\
\hline & JD. IRENE & 1 & 0,7 & 3 & 1,2 & 0 & 0,0 & 0 & 0,0 \\
\hline & JD. SANTO ANDRÉ & 0 & 0,0 & 5 & 2,0 & 0 & 0,0 & 3 & 3,2 \\
\hline & JD. RINA & 1 & 0,7 & 12 & 4,8 & 2 & 2,0 & 0 & 0,0 \\
\hline & JD. RIVIERA & 0 & 0,0 & 0 & 0,0 & 0 & 0,0 & 1 & 1,1 \\
\hline & $\begin{array}{l}\text { JD. SANTO ANTÔNIO DE } \\
\text { PÁDUA }\end{array}$ & 0 & 0,0 & 1 & 0,4 & 1 & 1,0 & 0 & 0,0 \\
\hline & JD. SANTA CATARINA & 0 & 0,0 & 0 & 0,0 & 1 & 1,0 & 0 & 0,0 \\
\hline & JD. TELLES DE MENEZES & 1 & 0,7 & 0 & 0,0 & 0 & 0,0 & 0 & 0,0 \\
\hline & PQ. GERASSI & 1 & 0,7 & 0 & 0,0 & 1 & 1,0 & 2 & 2,1 \\
\hline & PQ MIAMI & 0 & 0,0 & 0 & 0,0 & 0 & 0,0 & 1 & 1,1 \\
\hline & PQ. REPRESA BILLINGS II & 1 & 0,7 & 1 & 0,4 & 0 & 0,0 & 0 & 0,0 \\
\hline & PQ. REPRESA BILLINGS III & 0 & 0,0 & 0 & 0,0 & 1 & 1,0 & 0 & 0,0 \\
\hline & PQ. RIO GRANDE & 1 & 0,7 & 0 & 0,0 & 0 & 0,0 & 0 & 0,0 \\
\hline & $\begin{array}{l}\text { RECREIO DA BORDA DO } \\
\text { CAMPO }\end{array}$ & 4 & 2,8 & 8 & 3,2 & 2 & 2,0 & 52 & 55,3 \\
\hline & SITIO DOS VIANAS & 1 & 0,7 & 0 & 0,0 & 1 & 1,0 & 0 & 0,0 \\
\hline & SITIO TAQUARAL & 0 & 0,0 & 1 & 0,4 & 0 & 0,0 & 1 & 1,1 \\
\hline & VL. AQUILINO & 0 & 0,0 & 0 & 0,0 & 1 & 1,0 & 0 & 0,0 \\
\hline & VL. GUARACIABA & 1 & 0,7 & 4 & 1,6 & 0 & 0,0 & 1 & 1,1 \\
\hline & VL. JOAO RAMALHO & 0 & 0,7 & 2 & 0,8 & 0 & 0,0 & 0 & 0,0 \\
\hline & VL. PRINCIPE DE GALES & 1 & 0,7 & 1 & 0,4 & 1 & 1,0 & 0 & 0,0 \\
\hline & TOTAL & 143 & 100,0 & 250 & 100,0 & 102 & 100,0 & 94 & 100,00 \\
\hline
\end{tabular}

\subsection{Caracterização sócio-demográfica}

Em relação aos dados sócio-demográficos verificou-se que as famílias tinham em média quatro membros em todos os grupos. O número de famílias chefiadas por mulheres é maior nos grupos II e III (tabela 4), sendo a raça branca preponderante nos quatro grupos ressaltando-se que no grupo IV a proporção foi menor (tabela 5).

No que diz respeito à idade média dos chefes das famílias analisadas verificou-se que no grupo I ela era de 47,4 anos, no grupo II de 42 anos, no grupo III 
de 52,9 anos e no grupo IV de 40,2 anos, sendo portanto o grupo que apresentou chefes de família mais novos.

A maior parte dos chefes de família nasceu em Santo André ou na região Nordeste. Observa-se por meio da tabela 6 que os chefes nascidos no Nordeste são principalmente os do grupo social IV.

Tabela 4 - Distribuição dos indivíduos dos quatro novos grupos sociais segundo sexo do chefe de família. Santo André, SP, 2008.

\begin{tabular}{|c|c|c|c|c|c|c|c|c|c|c|}
\hline \multirow[b]{3}{*}{$\begin{array}{l}\text { Sexo chefe } \\
\text { de família }\end{array}$} & \multicolumn{8}{|c|}{ GRUPO SOCIAL } & & \\
\hline & \multicolumn{2}{|c|}{ I } & \multicolumn{2}{|c|}{ II } & \multicolumn{2}{|c|}{ III } & \multicolumn{2}{|c|}{ IV } & \multicolumn{2}{|c|}{ Total } \\
\hline & $\mathbf{N}$ & $\%$ & $\mathbf{N}$ & $\%$ & $\mathbf{N}$ & $\%$ & $\mathbf{N}$ & $\%$ & $\mathbf{N}$ & $\%$ \\
\hline Masculino & 118 & 82,5 & 177 & 70,8 & 65 & 63,7 & 73 & 77,7 & 433 & 73,5 \\
\hline Feminino & 25 & 17,5 & 73 & 29,2 & 37 & 36,3 & 21 & 22,3 & 156 & 26,5 \\
\hline Total & 143 & 100,0 & 250 & 100,0 & 102 & 100,0 & 94 & 100,0 & 589 & 100,0 \\
\hline
\end{tabular}

Tabela 5 - Distribuição dos indivíduos dos quatro novos grupos sociais segundo raça. Santo André, SP, 2008.

GRUPO SOCIAL

I II

IV

Total

\begin{tabular}{lcccccccccc} 
Raça & $\mathbf{N}$ & $\mathbf{\%}$ & $\mathbf{N}$ & $\mathbf{\%}$ & $\mathbf{N}$ & $\mathbf{\%}$ & $\mathbf{N}$ & $\mathbf{\%}$ & $\mathbf{N}$ & $\mathbf{\%}$ \\
\hline Preta & 11 & 7,7 & 34 & 13,6 & 11 & 10,8 & 11 & 11,7 & 67 & 11,4 \\
Parda & 29 & 20,3 & 71 & 28,4 & 23 & 22,5 & 44 & 46,8 & 167 & 28,4 \\
Branca & 102 & 71,3 & 137 & 54,8 & 65 & 63,7 & 39 & 41,5 & 343 & 58,2 \\
Amarela & 1 & 0,7 & 3 & 1,2 & 2 & 2,0 & 0 & 0,0 & 6 & 1,0 \\
Indígena & 0 & 0,0 & 5 & 2,0 & 1 & 1,0 & 0 & 0,0 & 6 & 1,0 \\
Total & $\mathbf{1 4 3}$ & $\mathbf{1 0 0 , 0}$ & $\mathbf{2 5 0}$ & $\mathbf{1 0 0 , 0}$ & $\mathbf{1 0 2}$ & $\mathbf{1 0 0 , 0}$ & $\mathbf{9 4}$ & $\mathbf{1 0 0 , 0}$ & $\mathbf{5 8 9}$ & $\mathbf{1 0 0 , 0}$
\end{tabular}


Tabela 6 - Distribuição dos indivíduos dos quatro novos grupos sociais segundo local de nascimento. Santo André, SP, 2008.

\begin{tabular}{|c|c|c|c|c|c|c|c|c|c|c|}
\hline \multirow[b]{3}{*}{ Nascimento } & \multicolumn{8}{|c|}{ GRUPO SOCIAL } & & \\
\hline & \multicolumn{2}{|c|}{ I } & \multicolumn{2}{|c|}{ II } & \multicolumn{2}{|c|}{ III } & \multicolumn{2}{|c|}{ IV } & \multicolumn{2}{|c|}{ Total } \\
\hline & $\mathbf{N}$ & $\%$ & $\mathbf{N}$ & $\%$ & $\mathbf{N}$ & $\%$ & $\mathbf{N}$ & $\%$ & $\mathbf{N}$ & $\%$ \\
\hline RMSP & 23 & 16,3 & 24 & 9,7 & 11 & 10,9 & 7 & 7,9 & 65 & 11,2 \\
\hline SP Interior & 22 & 15,6 & 42 & 16,9 & 19 & 18,8 & 9 & 10,1 & 92 & 15,9 \\
\hline Santo André & 34 & 24,1 & 66 & 26,6 & 23 & 22,8 & 17 & 19,1 & 140 & 24,2 \\
\hline $\begin{array}{l}\text { Grande ABC } \\
\text { exceto Santo } \\
\text { André }\end{array}$ & 13 & 9,2 & 14 & 5,6 & 4 & 4,0 & 5 & 5,6 & 36 & 6,2 \\
\hline Sudeste & 11 & 7,8 & 19 & 7,7 & 11 & 10,9 & 5 & 5,6 & 46 & 7,9 \\
\hline Sul & 9 & 6,4 & 16 & 6,5 & 3 & 3,0 & 7 & 7,9 & 35 & 6,0 \\
\hline Nordeste & 23 & 16,3 & 55 & 22,2 & 23 & 22,8 & 34 & 38,2 & 135 & 23,3 \\
\hline Norte & 2 & 1,4 & 7 & 2,8 & 5 & 5,0 & 5 & 5,6 & 19 & 3,3 \\
\hline Centro Oeste & 3 & 2,1 & 4 & 1,6 & 2 & 2,0 & 0 & 0,0 & 9 & 1,6 \\
\hline Outro país & 1 & 0,7 & 1 & 0,4 & 0 & 0,0 & 0 & 0,0 & 2 & 0,3 \\
\hline Total & 141 & 100,0 & 248 & 100,0 & 101 & 100,0 & 89 & 100,0 & $579 *$ & 100,0 \\
\hline
\end{tabular}

*Nota: Foram excluídos 10 chefes de família, a respeito dos quais não se obteve informação

A religião católica foi a mais presente em todos os grupos sociais, sendo a pentecostal a segunda mais referida e discretamente mais frequente no grupo social IV (tabela 7). Quando se verificou qual era o culto ou religião efetivamente praticada (tabela 8) observou-se que mais de um terço dos chefes dos quatro grupos não eram praticantes. A religião católica foi a que mais se destacou entre os que participavam ativamente de atividades religiosas. 
Tabela 7 - Distribuição dos indivíduos dos quatro novos grupos sociais segundo religião. Santo André, SP, 2008.

\section{GRUPO SOCIAL}

$\begin{array}{lllll}\text { I } & \text { II } & \text { III } & \text { IV } & \text { Total }\end{array}$

\begin{tabular}{lcccccccccc} 
Religião & $\mathbf{N}$ & $\mathbf{\%}$ & $\mathbf{N}$ & $\mathbf{\%}$ & $\mathbf{N}$ & $\mathbf{\%}$ & $\mathbf{N}$ & $\mathbf{\%}$ & $\mathbf{N}$ & $\mathbf{\%}$ \\
\hline Católica & 78 & 54,5 & 140 & 56,0 & 66 & 64,7 & 45 & 47,9 & 329 & 55,9 \\
Test. de Jeová & 3 & 2,1 & 5 & 2,0 & 0 & 0,0 & 1 & 1,1 & 9 & 1,5 \\
Histórico & 6 & 4,2 & 4 & 1,6 & 2 & 2,0 & 1 & 1,1 & 13 & 2,2 \\
Pentecostal & 34 & 23,8 & 52 & 20,8 & 19 & 18,6 & 23 & 24,5 & 128 & 21,7 \\
Espírita & 8 & 5,6 & 8 & 3,2 & 5 & 4,9 & 4 & 4,3 & 25 & 4,2 \\
Afrobrasileiro & 1 & 0,7 & 1 & 0,4 & 1 & 1,0 & 1 & 1,1 & 4 & 0,7 \\
Sem & 8 & 5,6 & 22 & 8,8 & 6 & 5,9 & 15 & 16,0 & 51 & 8,7 \\
religião/culto & & & & & & & & & & \\
$\begin{array}{l}\text { Não } \\
\text { determinada }\end{array}$ & 5 & 3,5 & 18 & 7,2 & 3 & 2,9 & 4 & 4,3 & 30 & 5,1 \\
Total & $\mathbf{1 4 3}$ & $\mathbf{1 0 0 , 0}$ & $\mathbf{2 5 0}$ & $\mathbf{1 0 0 , 0}$ & $\mathbf{1 0 2}$ & $\mathbf{1 0 0 , 0}$ & $\mathbf{9 4}$ & $\mathbf{1 0 0 , 0}$ & $\mathbf{5 8 9}$ & $\mathbf{1 0 0 , 0}$ \\
\hline
\end{tabular}

Tabela 8 - Distribuição dos chefes de família dos quatro novos grupos sociais segundo culto ou religião praticada. Santo André, SP, 2008.

\begin{tabular}{|c|c|c|c|c|c|c|c|c|c|c|}
\hline \multicolumn{11}{|c|}{ GRUPO SOCIAL } \\
\hline & \multicolumn{2}{|c|}{ I } & \multicolumn{2}{|c|}{ II } & \multicolumn{2}{|c|}{ III } & \multicolumn{2}{|c|}{ IV } & \multicolumn{2}{|c|}{ Total } \\
\hline Religião & $\mathbf{N}$ & $\%$ & $\mathbf{N}$ & $\%$ & $\mathbf{N}$ & $\%$ & $\mathbf{N}$ & $\%$ & $\mathbf{N}$ & $\%$ \\
\hline \multicolumn{11}{|l|}{ praticada } \\
\hline Católica & 39 & 27,3 & 66 & 26,4 & 33 & 32,4 & 29 & 30,9 & 39 & 27,3 \\
\hline Test. de Jeová & 3 & 2,1 & 5 & 2,0 & 0 & 0,0 & 2 & 2,1 & 3 & 2,1 \\
\hline Histórico & 5 & 3,5 & 3 & 1,2 & 3 & 2,9 & 1 & 1,1 & 5 & 3,5 \\
\hline Pentecostal & 34 & 23,8 & 43 & 17,2 & 20 & 19,6 & 23 & 24,5 & 34 & 23,8 \\
\hline Espírita & 6 & 4,2 & 6 & 2,4 & 4 & 3,9 & 3 & 3,2 & 6 & 4,2 \\
\hline Afrobrasileiro & 1 & 0,7 & 1 & 0,4 & 0 & 0,0 & 1 & 1,1 & 1 & 0,7 \\
\hline Religiões & 1 & 0,7 & 0 & 0,0 & 0 & 0,0 & 0 & 0,0 & 1 & 0,7 \\
\hline \multicolumn{11}{|l|}{ Orientais } \\
\hline $\begin{array}{l}\text { Sem } \\
\text { religião/culto }\end{array}$ & 49 & 34,3 & 100 & 40,0 & 38 & 37,3 & 29 & 30,9 & 49 & 34,3 \\
\hline $\begin{array}{l}\text { Não } \\
\text { determinada }\end{array}$ & 5 & 3,5 & 25 & 10,0 & 4 & 3,9 & 6 & 6,4 & 5 & 3,5 \\
\hline Outras & 0 & 0,0 & 1 & 0,4 & 0 & 0,0 & 0 & 0,0 & 0 & 0,0 \\
\hline Total & 143 & 100,00 & 250 & 100,00 & 102 & 100,00 & 94 & 100,00 & 589 & 100,00 \\
\hline
\end{tabular}




\section{3- Formas de trabalhar- dimensão da produção}

Quanto à escolaridade, chama a atenção o fato de que quase $40 \%$ dos chefes do grupo I tinham ensino superior enquanto que apenas 2,1\% dos chefes do Grupo IV alcançaram tal escolaridade.

Tabela 9 - Distribuição dos indivíduos dos quatro novos grupos sociais segundo escolaridade. Santo André, SP, 2008.

\begin{tabular}{|c|c|c|c|c|c|c|c|c|c|c|}
\hline \multirow[b]{3}{*}{ Escolaridade } & \multicolumn{8}{|c|}{ GRUPO SOCIAL } & & \\
\hline & \multicolumn{2}{|c|}{$\mathbf{I}$} & \multicolumn{2}{|c|}{ II } & \multicolumn{2}{|c|}{ III } & \multicolumn{2}{|c|}{ IV } & \multicolumn{2}{|c|}{ Total } \\
\hline & $\mathbf{N}$ & $\%$ & $\mathbf{N}$ & $\%$ & $\mathbf{N}$ & $\%$ & $\mathbf{N}$ & $\%$ & $\mathbf{N}$ & $\%$ \\
\hline $\begin{array}{l}\text { EF } \\
\text { incompleto }\end{array}$ & 14 & 9,8 & 69 & 27,8 & 36 & 36,0 & 28 & 29,8 & 147 & 25,1 \\
\hline $\begin{array}{l}\text { EF completo/ } \\
\text { Médio } \\
\text { Incompl }\end{array}$ & 18 & 12,6 & 64 & 25,8 & 17 & 17,0 & 22 & 23,4 & 121 & 20,7 \\
\hline EM Completo & 41 & 28,7 & 82 & 33,1 & 33 & 33,0 & 30 & 31,9 & 186 & 31,8 \\
\hline $\begin{array}{l}\text { Superior } \\
\text { incompl/ } \\
\text { completo }\end{array}$ & 55 & 38,5 & 21 & 8,5 & 8 & 8,0 & 2 & 2,1 & 86 & 14,7 \\
\hline $\begin{array}{l}\text { Pós- } \\
\text { graduação }\end{array}$ & 13 & 9,1 & 3 & 1,2 & 2 & 2,0 & 0 & 0,0 & 18 & 3,1 \\
\hline $\begin{array}{l}\text { Supletivo } \\
\text { EF/EM }\end{array}$ & 1 & 0,7 & 5 & 2,0 & 0 & 0,0 & 8 & 8,5 & 14 & 2,4 \\
\hline $\begin{array}{l}\text { Sabe } \\
\text { Ler/Escrever/ } \\
\text { Analfabeto }\end{array}$ & 1 & 0,7 & 4 & 1,6 & 4 & 4,0 & 4 & 4,3 & 13 & 2,2 \\
\hline Total & 143 & 100,0 & 248 & 100,0 & 100 & 100,0 & 94 & 100,0 & $585^{*}$ & 100,0 \\
\hline
\end{tabular}

*Nota: Foram excluídos 4 chefes de família, a respeito dos quais não se obteve informação

No que diz respeito à condição de atividade ressalta-se que os não economicamente ativos (donas de casa, não inseridos, aposentados, pensionistas, desempregados) concentram-se no grupo III e estão praticamente ausentes no grupo I (tabela 10). 
Tabela 10 - Distribuição dos chefes de família dos quatro novos grupos sociais segundo condição de atividade. Santo André, SP, 2008.

\section{GRUPO SOCIAL}

\begin{tabular}{|c|c|c|c|c|c|c|c|c|c|c|}
\hline \multirow[b]{2}{*}{$\begin{array}{ll}\text { Condição de } \\
\text { atividade }\end{array}$} & \multicolumn{2}{|c|}{$\mathbf{I}$} & \multicolumn{2}{|c|}{ II } & \multicolumn{2}{|c|}{ III } & \multicolumn{2}{|c|}{ IV } & \multicolumn{2}{|c|}{ Total } \\
\hline & $\mathbf{N}$ & $\%$ & $\mathbf{N}$ & $\%$ & $\mathbf{N}$ & $\%$ & $\mathbf{N}$ & $\%$ & $\mathbf{N}$ & $\%$ \\
\hline Bico & 0 & 0,0 & 10 & 4,0 & 0 & 0,0 & 4 & 4,3 & 14 & 2,4 \\
\hline Desempregado & 0 & 0,0 & 0 & 0,0 & 16 & 15,7 & 4 & 4,3 & 20 & 3,4 \\
\hline $\begin{array}{l}\text { Dona de casa, } \\
\text { não inserido }\end{array}$ & 0 & 0,0 & 0 & 0,0 & 11 & 10,8 & 2 & 2,1 & 13 & 2,2 \\
\hline $\begin{array}{l}\text { Trabalhador } \\
\text { familiar }\end{array}$ & 4 & 2,8 & 3 & 1,2 & 0 & 0,0 & 0 & 0,0 & 7 & 1,2 \\
\hline Autônomo & 28 & 19,6 & 46 & 18,4 & 1 & 1,0 & 15 & 15,9 & 90 & 15,3 \\
\hline $\begin{array}{l}\text { Aposentado, } \\
\text { pensionista, } \\
\text { afastado do } \\
\text { trabalho }\end{array}$ & 1 & 0,7 & 0 & 0,0 & 70 & 68,6 & 10 & 10,6 & 81 & 13,7 \\
\hline Empregador & 7 & 4,9 & 6 & 2,4 & 0 & 0,0 & 2 & 2,1 & 15 & 2,5 \\
\hline Assalariado & 103 & 72,0 & 185 & 74,0 & 4 & 3,9 & 57 & 60,6 & 349 & 59,3 \\
\hline Total & 143 & 100,0 & 250 & 100,0 & 102 & 100,0 & 94 & 100,0 & 589 & 100,0 \\
\hline
\end{tabular}

Quase metade dos chefes de família do grupo I trabalhava em ocupações que envolviam atividades de planejamento, gerência ou direção (tabela 11). O grupo II foi o segundo grupo a apresentar maior porcentagem de chefes de família com melhor qualificação. Ressalta-se que o grupo III apresenta especificidades devido à grande porcentagem de chefes de família não inseridos. Cerca de um terço do grupo IV exercia atividades semi qualificadas na execução. A caracterização das ocupações segue as orientações do SEADE que utiliza como referência a Classificação Brasileira de Ocupações (Ministério do Trabalho e do Emprego, 2011). O detalhamento das ocupações se apresenta na tabela 12. 
Tabela 11 - Distribuição dos chefes de família dos quatro novos grupos sociais segundo qualificação da ocupação Santo André, SP, 2008.

\begin{tabular}{|c|c|c|c|c|c|c|c|c|c|c|c|}
\hline \multirow[b]{3}{*}{$\begin{array}{l}\text { Qualificação } \\
\text { para } \\
\text { trabalho }\end{array}$} & \multicolumn{9}{|c|}{ GRUPO SOCIAL } & & \\
\hline & & \multicolumn{2}{|c|}{ I } & \multicolumn{2}{|c|}{ II } & \multicolumn{2}{|c|}{ III } & \multicolumn{2}{|c|}{ IV } & \multicolumn{2}{|c|}{ Total } \\
\hline & $\mathbf{0}$ & $\mathbf{N}$ & $\%$ & $\mathbf{N}$ & $\%$ & $\mathbf{N}$ & $\%$ & $\mathbf{N}$ & $\%$ & $\mathbf{N}$ & $\%$ \\
\hline Mal definidas & & 1 & 0.7 & 27.0 & 10.8 & 0.0 & 0.0 & 12.0 & 16.4 & 40.0 & 8.6 \\
\hline $\begin{array}{l}\text { Não } \\
\text { operacional. } \\
\text { apoio }\end{array}$ & & 4 & 2.8 & 21.0 & 8.4 & 0.0 & 0.0 & 5.0 & 6.8 & 30.0 & 6.4 \\
\hline $\begin{array}{l}\text { Serviços de } \\
\text { escritório }\end{array}$ & & 1 & 0.7 & 8.0 & 3.2 & 0.0 & 0.0 & 0.0 & 0.0 & 9.0 & 1.9 \\
\hline Serviços gerais & & 3 & 2.1 & 13.0 & 5.2 & 0.0 & 0.0 & 5.0 & 6.8 & 21.0 & 4.5 \\
\hline $\begin{array}{l}\text { Não qualificado } \\
\text { na execução }\end{array}$ & & 3 & 2.1 & 41.0 & 16.4 & 2.0 & 100.0 & 10.0 & 13.7 & 56.0 & 12.0 \\
\hline $\begin{array}{l}\text { Semi } \\
\text { Qualificado na } \\
\text { execução }\end{array}$ & & 40 & 28.4 & 102.0 & 40.8 & 0.0 & 0.0 & 33.0 & 45.2 & 175.0 & 37.6 \\
\hline $\begin{array}{l}\text { Qualificado na } \\
\text { execução }\end{array}$ & & 22 & 15.6 & 15.0 & 6.0 & 0.0 & 0.0 & 3.0 & 4.1 & 40.0 & 8.6 \\
\hline $\begin{array}{l}\text { Planejamento } \\
\text { Organização }\end{array}$ & $\mathrm{e}$ & 34 & 24.1 & 8.0 & 3.2 & 0.0 & 0.0 & 0.0 & 0.0 & 42.0 & 9.0 \\
\hline $\begin{array}{l}\text { Empresário. } \\
\text { direção } \\
\text { gerência }\end{array}$ & e & 33 & 23.4 & 15.0 & 6.0 & 0.0 & 0.0 & 5.0 & 6.8 & 53.0 & 11.4 \\
\hline Total & & 141 & 100.0 & 250 & 100 & 2 & 100.0 & 73 & 100 & 466 & 100 \\
\hline
\end{tabular}

*Nota: Foram excluídos 123 chefes de família, a respeito dos quais não se obteve informação ou a variável não se aplicava. 
Tabela 12 - Distribuição dos chefes de família dos quatro novos grupos sociais segundo ocupação. Santo André, SP, 2008.

(continua)

\begin{tabular}{|c|c|c|c|c|c|c|c|c|}
\hline \multirow{3}{*}{ OCUPAÇÕES } & \multicolumn{8}{|c|}{ GRUPO SOCIAL } \\
\hline & \multicolumn{2}{|c|}{$\mathbf{I}$} & \multicolumn{2}{|c|}{ II } & \multicolumn{2}{|c|}{ III } & \multicolumn{2}{|c|}{ IV } \\
\hline & $\mathbf{N}$ & $\%$ & $\mathbf{N}$ & $\%$ & $\mathbf{N}$ & $\%$ & $\mathbf{N}$ & $\%$ \\
\hline \multirow{2}{*}{\multicolumn{9}{|c|}{$\begin{array}{l}\text { 1. DIREÇÃO E PLANEJAMENTO } \\
\text { 1.1. Planeiamento e organizacão }\end{array}$}} \\
\hline & & & & & & & & \\
\hline Farmacêuticos, químicos & 2 & 1,4 & 0 & 0,0 & 0 & 0,0 & 0 & 0,0 \\
\hline Arquitetos, engenheiros & 6 & 4,2 & 0 & 0,0 & 0 & 0,0 & 0 & 0,0 \\
\hline Médicos & 1 & 0,7 & 0 & 0,0 & 0 & 0,0 & 0 & 0,0 \\
\hline Dentistas & 1 & 0,7 & 0 & 0,0 & 0 & 0,0 & 0 & 0,0 \\
\hline Estatísticos & 1 & 0,7 & 0 & 0,0 & 0 & 0,0 & 0 & 0,0 \\
\hline Programadores de computadores & 0 & 0,0 & 1 & 0,4 & & 0,0 & 0 & 0,0 \\
\hline Economistas & 1 & 0,7 & 0 & 0,0 & 0 & 0,0 & 0 & 0,0 \\
\hline Contadores e auditores contábeis & 2 & 1,4 & 0 & 0,0 & 0 & 0,0 & 0 & 0,0 \\
\hline Fiscais e técnicos de arrecadação e & 2 & 1,4 & 0 & 0,0 & 0 & 0,0 & 0 & 0,0 \\
\hline $\begin{array}{l}\text { tributação, advogados e defensores públicos, } \\
\text { Professores de ensino superior, professores } \\
\text { pesquisadores }\end{array}$ & 2 & 1,4 & 0 & 0,0 & 0 & 0,0 & 0 & 0,0 \\
\hline $\begin{array}{l}\text { Diretores de escolas, professores de ensino } \\
\text { não especificado, técnicos de ensino, } \\
\text { inspetores de alunos, orientadores de ensino. }\end{array}$ & 6 & 4,2 & 4 & 1,6 & 0 & 0,0 & 0 & 0,0 \\
\hline $\begin{array}{l}\text { Arquivologistas, bibliotecários, museólogos, } \\
\text { ocupações técnicas e cientificas não } \\
\text { especificadas }\end{array}$ & 4 & 2,8 & 1 & 0,4 & 0 & 0,0 & 0 & 0,0 \\
\hline $\begin{array}{l}\text { Antropólogos, Geógrafos, Arqueólogos, } \\
\text { Sociólogos, Demógrafos }\end{array}$ & 0 & 0,0 & 1 & 0,4 & 0 & 0,0 & 0 & 0,0 \\
\hline $\begin{array}{l}\text { Chefes e encarregados de seção de serviços } \\
\text { administrativos de empresas }\end{array}$ & 1 & 0,7 & 0 & 0,0 & 0 & 0,0 & 0 & 0,0 \\
\hline $\begin{array}{l}\text { Chefes e encarregados de sessão na produção } \\
\text { industrial }\end{array}$ & 5 & 3,5 & 1 & 0,4 & 0 & 0,0 & 0 & 0,0 \\
\hline Subtotal & 34 & 23,8 & 8 & 3,2 & $\mathbf{0}$ & $\mathbf{0 , 0}$ & $\mathbf{0}$ & $\mathbf{0 , 0}$ \\
\hline \multicolumn{9}{|l|}{ 1.2. Empresário, direção e gerência } \\
\hline Diretores e produtores de espetáculos & 1 & 0,7 & 0 & 0,0 & 0 & 0,0 & 0 & 0,0 \\
\hline Empresários do comércio & 1 & 0,7 & 0 & 0,0 & 0 & 0,0 & 3 & 4,1 \\
\hline $\begin{array}{l}\text { Administradores e gerentes da indústrias de } \\
\text { transformação }\end{array}$ & 1 & 0,7 & 0 & 0,0 & 0 & 0,0 & 0 & 0,0 \\
\hline $\begin{array}{l}\text { Administradores e gerentes do comércio e de } \\
\text { serviços }\end{array}$ & 15 & 10,5 & 11 & 4,4 & 0 & 0,0 & 2 & 2,7 \\
\hline $\begin{array}{l}\text { Administradores do setor bancário e } \\
\text { financeiro }\end{array}$ & 1 & 0,7 & 1 & 0,4 & 0 & 0,0 & 0 & 0,0 \\
\hline $\begin{array}{l}\text { Outros administradores e gerentes não } \\
\text { classificados }\end{array}$ & 14 & 9,8 & 3 & 1,2 & 0 & 0,0 & 0 & 0,0 \\
\hline Subtotal & 33 & 23,1 & 15 & 6,0 & $\mathbf{0}$ & $\mathbf{0 , 0}$ & 5 & 6,8 \\
\hline
\end{tabular}


Tabela 12 - Distribuição dos chefes de família dos quatro novos grupos sociais segundo ocupação. Santo André, SP, 2008.

(continuação)

\begin{tabular}{|c|c|c|c|c|c|c|c|c|}
\hline \multirow{3}{*}{ OCUPAÇÕES } & \multicolumn{8}{|c|}{ GRUPO SOCIAL } \\
\hline & \multicolumn{2}{|c|}{$\mathbf{I}$} & \multicolumn{2}{|c|}{ II } & \multicolumn{2}{|c|}{ III } & \multicolumn{2}{|c|}{ IV } \\
\hline & $\mathbf{N}$ & $\%$ & $\mathbf{N}$ & $\%$ & $\mathbf{N}$ & $\%$ & $\mathbf{N}$ & $\%$ \\
\hline \multicolumn{9}{|l|}{ 2. EXECUÇÃO } \\
\hline \multicolumn{9}{|l|}{ 2.1. Não qualificado na execução } \\
\hline Carteiros & 0 & 0,0 & 1 & 0,4 & 0 & 0,0 & 1 & 1,4 \\
\hline Frentistas, repositores de mercadorias & 0 & 0,0 & 1 & 0,4 & 0 & 0,0 & 0 & 0,0 \\
\hline Baleiro, sorveteiros, doceiros, comerciantes & & & & & & & & \\
\hline $\begin{array}{l}\text { ambulantes, bilheteiro, leiteiro, feirante, } \\
\text { peixeiro, quitandeiro. }\end{array}$ & 0 & 0,0 & 6 & 2,4 & 0 & 0,0 & 3 & 4,1 \\
\hline \multicolumn{9}{|l|}{ Copeiros, garçons, atendentes de bares e } \\
\hline lanchonetes & 0 & 0,0 & 6 & 2,4 & 0 & 0,0 & 1 & 1,4 \\
\hline Camareiros, empregados domésticos & 1 & 0,7 & 20 & 8,0 & 2 & 100,0 & 5 & 6,8 \\
\hline Operadores de máquina de marcenaria & 0 & 0,0 & 1 & 0,4 & 0 & 0,0 & 0 & 0,0 \\
\hline Operadores de máquina na indústria de & & & & & & & & \\
\hline artefatos de borracha e plástico & 1 & 0,7 & 1 & 0,4 & 0 & 0,0 & 0 & 0,0 \\
\hline Pintores e caiadores & 1 & 0,7 & 3 & 1,2 & 0 & 0,0 & 0 & 0,0 \\
\hline Vidraceiros & 0 & 0,0 & 2 & 0,8 & 0 & 0,0 & 0 & 0,0 \\
\hline Subtotal & 3 & 2,1 & 41 & 16,4 & 2 & 100,0 & 10 & 13,7 \\
\hline \multicolumn{9}{|l|}{ 2.2. Semi-qualificado na execução } \\
\hline Enfermeiros não diplomados & 3 & 2,1 & 4 & 1,6 & 0 & 0,0 & 1 & 1,4 \\
\hline Jogadores de futebol e outros atletas & 0 & 0,0 & 1 & 0,4 & 0 & 0,0 & 0 & 0,0 \\
\hline Inspetores e fiscais, guardas sanitários & 3 & 2,1 & 1 & 0,4 & 0 & 0,0 & 1 & 1,4 \\
\hline $\begin{array}{l}\text { Representantes, pracistas e viajantes } \\
\text { comerciais }\end{array}$ & 1 & 0,7 & 1 & 0,4 & 0 & 0,0 & 0 & 0,0 \\
\hline $\begin{array}{l}\text { Corretores de títulos de valores, de seguros, } \\
\text { de bolsa de valores e de imóveis }\end{array}$ & 0 & 0,0 & 1 & 0,4 & 0 & 0,0 & 0 & 0,0 \\
\hline Promotor de vendas e propagandistas & 0 & 0,0 & 1 & 0,4 & 0 & 0,0 & 0 & 0,0 \\
\hline Vendedores & 5 & 3,5 & 18 & 7,2 & 0 & 0,0 & 1 & 1,4 \\
\hline Cozinheiros & 3 & 2,1 & 6 & 2,4 & 0 & 0,0 & 1 & 1,4 \\
\hline $\begin{array}{l}\text { Cabeleireiro, manicure, barbeiro, esteticista, } \\
\text { maquilador. }\end{array}$ & 1 & 0,7 & 2 & 0,8 & 0 & 0,0 & 0 & 0,0 \\
\hline $\begin{array}{l}\text { Vigias particulares, guardas de presídios, } \\
\text { carcereiros. }\end{array}$ & 3 & 2,1 & 7 & 2,8 & 0 & 0,0 & 3 & 4,1 \\
\hline Tecelões, tricoteiros, tapeceiros & 0 & 0,0 & 1 & 0,4 & 0 & 0,0 & 0 & $\begin{array}{l}+, 1 \\
0,0\end{array}$ \\
\hline Pasteleiro, confeiteiro, padeiro & 1 & 0,7 & 2 & 0,8 & 0 & 0,0 & 1 & 1,4 \\
\hline Costureiros, alfaiates & 2 & 1,4 & 5 & 2,0 & 0 & 0,0 & 1 & 1,4 \\
\hline Bordadeiras, cerzideiras & 0 & 0,0 & 1 & 0,4 & 0 & 0,0 & 0 & 0,0 \\
\hline Sapateiros & 0 & 0,0 & 1 & 0,4 & 0 & 0,0 & 0 & 0,0 \\
\hline Marceneiros & 1 & 0,7 & 3 & 1,2 & 0 & 0,0 & 3 & 4,1 \\
\hline Ferreiros, serralheiros & 0 & 0,0 & 2 & 0,8 & 0 & 0,0 & 0 & 0,0 \\
\hline $\begin{array}{l}\text { Furadores, frisadores, retificadores, torneiros } \\
\text { mecânicos. }\end{array}$ & 0 & 0,0 & 1 & 0,4 & 0 & 0,0 & 1 & 1,4 \\
\hline
\end{tabular}


Tabela 12 - Distribuição dos chefes de família dos quatro novos grupos sociais segundo ocupação. Santo André, SP, 2008.

(continuação)

\begin{tabular}{|c|c|c|c|c|c|c|c|c|}
\hline \multirow{3}{*}{ OCUPAÇÕES } & \multicolumn{8}{|c|}{ GRUPO SOCIAL } \\
\hline & \multicolumn{2}{|c|}{ I } & \multicolumn{2}{|c|}{ II } & \multicolumn{2}{|c|}{ III } & \multicolumn{2}{|r|}{ IV } \\
\hline & $\mathbf{N}$ & $\%$ & $\mathbf{N}$ & $\%$ & $\mathbf{N}$ & $\%$ & $\mathbf{N}$ & $\%$ \\
\hline $\begin{array}{l}\text { Estampadores mecânicos, operadores de } \\
\text { prensa mecânica de metais }\end{array}$ & 1 & 0,7 & 0 & 0,0 & 0 & 0,0 & 0 & 0,0 \\
\hline Mecânicos sem especificação & 1 & 0,7 & 3 & 1,2 & 0 & 0,0 & 1 & 1,4 \\
\hline Montadores de equipamentos elétricos & 1 & 0,7 & 0 & 0,0 & 0 & 0,0 & 0 & 0,0 \\
\hline $\begin{array}{l}\text { Eletricistas de instalações, reparadores de } \\
\text { equipamentos elétricos }\end{array}$ & 2 & 1,4 & 7 & 2,8 & 0 & 0,0 & 1 & 1,4 \\
\hline $\begin{array}{l}\text { Operadores de equipamentos de som e } \\
\text { cenografia e outros operadores não } \\
\text { especificados }\end{array}$ & 0 & 0,0 & 0 & 0,0 & 0 & 0,0 & 1 & 1,4 \\
\hline Soldadores & 1 & 0,7 & 0 & 0,0 & 0 & 0,0 & 1 & 1,4 \\
\hline Lanterneiros de veículos e funileiros & 0 & 0,0 & 1 & 0,4 & 0 & 0,0 & 0 & 0,0 \\
\hline $\begin{array}{l}\text { Rebitadores e montadores de estruturas } \\
\text { metálicas }\end{array}$ & 0 & 0,0 & 1 & 0,4 & 0 & 0,0 & 0 & 0,0 \\
\hline $\begin{array}{l}\text { Borracheiros, } \\
\text { recauchutadores }\end{array}$ & 0 & 0,0 & 0 & 0,0 & 0 & 0,0 & 1 & 1,4 \\
\hline $\begin{array}{l}\text { Impressores e outras ocupações da indústria } \\
\text { gráfica }\end{array}$ & 0 & 0,0 & 0 & 0,0 & 0 & 0,0 & 1 & 1,4 \\
\hline Pedreiros & 1 & 0,7 & 10 & 4,0 & 0 & 0,0 & 5 & 6,8 \\
\hline $\begin{array}{l}\text { Caldeireiros, operadores de máquinas } \\
\text { (exclusive de agropecuária e construção, } \\
\text { operadores de tratamento e bombeamento }\end{array}$ & 2 & 1,4 & 4 & 1,6 & 0 & 0,0 & 0 & 0,0 \\
\hline $\begin{array}{l}\text { Motoristas, operadores de máquinas de } \\
\text { construção civil }\end{array}$ & 8 & 5,6 & 18 & 7,2 & 0 & 0,0 & 9 & 12,3 \\
\hline Subtotal & 40 & 28,8 & 102 & 40,8 & $\mathbf{0}$ & $\mathbf{0 , 0}$ & 33 & 45,5 \\
\hline 2.3. Qualificado na execução & & & & & & & & \\
\hline $\begin{array}{l}\text { Técnicos em estatística, em análise de dados, } \\
\text { de contabilidade e pesquisadores de mercado }\end{array}$ & 1 & 1,1 & 0 & 0,0 & 0 & 0,0 & 0 & 0,0 \\
\hline $\begin{array}{l}\text { Técnicos de agropecuária, eletrônica, } \\
\text { eletrotécnica, mecânica. enfermagem, } \\
\text { análises clínicas. }\end{array}$ & 4 & 2,8 & 2 & 0,8 & 0 & 0,0 & 0 & 0,0 \\
\hline $\begin{array}{l}\text { Técnicos de estradas, de saneamento, } \\
\text { edificações, de agrimensura, ocupações } \\
\text { auxiliares de engenharia e de arquitetura, } \\
\text { desenhistas }\end{array}$ & 3 & 2,1 & 0 & 0,0 & 0 & 0,0 & 0 & 0,0 \\
\hline Técnicos químicos & 3 & 2,1 & 0 & 0,0 & 0 & 0,0 & 0 & 0,0 \\
\hline Ortoptistas e óticos & 0 & 0,0 & 0 & 0,0 & 0 & 0,0 & 1 & 1,4 \\
\hline Professores de ensino fundamental & 2 & 1,4 & 0 & 0,0 & 0 & 0,0 & 0 & 0,0 \\
\hline Instrutores e professores de formação & 1 & 0,7 & 1 & 0,4 & 0 & 0,0 & 0 & 0,0 \\
\hline
\end{tabular}

Tabela 12 - Distribuição dos chefes de família dos quatro novos grupos sociais segundo ocupação. Santo André, SP, 2008. 
(continuação)

\begin{tabular}{|c|c|c|c|c|c|c|c|c|}
\hline \multirow{3}{*}{ OCUPAÇÕES } & \multicolumn{8}{|c|}{ GRUPO SOCIAL } \\
\hline & \multicolumn{2}{|c|}{ I } & \multicolumn{2}{|c|}{ II } & \multicolumn{2}{|c|}{ III } & \multicolumn{2}{|c|}{ IV } \\
\hline & $\mathbf{N}$ & $\%$ & $\mathbf{N}$ & $\%$ & $\mathbf{N}$ & $\%$ & $\mathbf{N}$ & $\%$ \\
\hline $\begin{array}{l}\text { Artistas plásticos, escultores, pintores, } \\
\text { artesãos }\end{array}$ & 1 & 0,7 & 0 & 0,0 & 0 & 0,0 & 0 & 0,0 \\
\hline Operadores de câmeras e fotógrafos & 1 & 0,7 & 0 & 0,0 & 0 & 0,0 & 0 & 0,0 \\
\hline Ferramenteiros & 3 & 2,1 & 1 & 0,4 & 0 & 0,0 & 0 & 0,0 \\
\hline Montadores na indústria metalúrgica & 0 & 0,0 & 1 & 0,4 & 0 & 0,0 & 0 & 0,0 \\
\hline Mecânicos de veículos automotores & 3 & 2,1 & 7 & 2,8 & 0 & 0,0 & 0 & 0,0 \\
\hline Ajustadores e montadores mecânicos, & 0 & O & 0 & $0 \Omega$ & 0 & 0 & 2 & 27 \\
\hline Encanadores & 0 & 0,0 & 3 & 1,2 & 0 & 0,0 & 0 & $\begin{array}{l}2,1 \\
0,0\end{array}$ \\
\hline Subtotal & 22 & 15,4 & 15 & 6,0 & $\mathbf{0}$ & $\mathbf{0 , 0}$ & 3 & 4,1 \\
\hline \multicolumn{9}{|l|}{ 3. APOIO } \\
\hline \multicolumn{9}{|l|}{ 3.1. Serviços gerais } \\
\hline Recepcionistas & 0 & 0,0 & 1 & 0,4 & 0 & 0,0 & 2 & 2,7 \\
\hline Porteiros, zeladores, ascensoristas & 3 & 2,1 & 6 & 2,4 & 0 & 0,0 & 1 & 1,4 \\
\hline Faxineiros, serventes, lixeiros & 0 & 2,1 & 6 & 2,4 & 0 & 0,0 & 1 & 1,4 \\
\hline Guardadores de automóveis & 0 & 0,0 & 0 & 0,0 & 0 & 0,0 & 1 & 1,4 \\
\hline Subtotal & 3 & 2,1 & 13 & 5,2 & $\mathbf{0}$ & $\mathbf{0 , 0}$ & 5 & 6,9 \\
\hline \multicolumn{9}{|l|}{ 3.2. Serviços de escritório } \\
\hline Secretárias & 0 & 0,0 & 4 & 1,6 & 0 & 0,0 & 0 & 0,0 \\
\hline $\begin{array}{l}\text { Pagadores, caixas, auxiliares de } \\
\text { contabilidade e contas a pagar }\end{array}$ & 1 & 0,7 & 4 & 1,6 & 0 & 0,0 & 0 & 0,0 \\
\hline Subtotal & 1 & $\mathbf{0 , 7}$ & 8 & 3,2 & $\mathbf{0}$ & $\mathbf{0 , 0}$ & $\mathbf{0}$ & $\mathbf{0 , 0}$ \\
\hline \multicolumn{9}{|l|}{ 3.3. Não Operacional/apoio } \\
\hline $\begin{array}{l}\text { Oficiais forças armadas, bombeiros, guardas } \\
\text { metropolitanos e civis }\end{array}$ & 1 & 0,7 & 4 & 1,6 & 0 & 0,0 & 1 & 1,4 \\
\hline Telegrafista, radiotelegrafista, telefonista & 0 & 0,0 & 1 & 0,4 & 0 & 0,0 & 0 & 0,0 \\
\hline $\begin{array}{l}\text { Despachantes de cargas, ônibus e trens, } \\
\text { armazenistas, conferentes de materiais, } \\
\text { almoxarifes, estoquistas }\end{array}$ & 2 & 1,4 & 5 & 2,0 & 0 & 0,0 & 0 & 0,0 \\
\hline $\begin{array}{l}\text { Apontador, auxiliares de escritório e } \\
\text { administrativos, escriturário. }\end{array}$ & 1 & 0,7 & 4 & 1,6 & 0 & 0,0 & 2 & 2,7 \\
\hline $\begin{array}{l}\text { Instaladores e reparadores de equipamentos e } \\
\text { aparelhos de telecomunicação }\end{array}$ & 0 & 0,0 & 3 & 1,2 & 0 & 0,0 & 0 & 0,0 \\
\hline Operadores de empilhadoras & 0 & 0,0 & 4 & 1,6 & 0 & 0,0 & 0 & 0,0 \\
\hline $\begin{array}{l}\text { Condutores e chefes de trem, maquinistas de } \\
\text { trem }\end{array}$ & 0 & 0,0 & 0 & 0,0 & 0 & 0,0 & 2 & 2,7 \\
\hline Subtotal & 4 & 2,8 & 21 & 8,4 & $\mathbf{0}$ & $\mathbf{0 , 0}$ & 5 & 6,8 \\
\hline
\end{tabular}


Tabela 12 - Distribuição dos chefes de família dos quatro novos grupos sociais segundo ocupação. Santo André, SP, 2008.

(conclusão)

\begin{tabular}{|c|c|c|c|c|c|c|c|c|}
\hline \multirow{3}{*}{ OCUPAÇÕES } & \multicolumn{8}{|c|}{ GRUPO SOCIAL } \\
\hline & \multicolumn{2}{|c|}{$\mathbf{I}$} & \multicolumn{2}{|c|}{ II } & \multicolumn{2}{|r|}{ III } & \multicolumn{2}{|c|}{ IV } \\
\hline & $\mathbf{N}$ & $\%$ & $\mathbf{N}$ & $\%$ & $\mathbf{N}$ & $\%$ & $\mathbf{N}$ & $\%$ \\
\hline 4. MAL DEFINIDAS & & & & & & & & \\
\hline $\begin{array}{l}\text { Outras ocupações da indústria de } \\
\text { transformação }\end{array}$ & 0 & 0,0 & 20 & 8,0 & 0 & 0,0 & 7 & 9,6 \\
\hline Outras ocupações ou ocupações mal & & & & & 0 & 0,0 & & \\
\hline definidas & 1 & 0,7 & 7 & 2,8 & & & 5 & 6,8 \\
\hline Subtotal & 1 & 0,7 & 27 & 10,8 & $\mathbf{0}$ & $\mathbf{0 , 0}$ & 12 & 16,4 \\
\hline Total & 141 & 100,0 & 250 & 100,0 & 2 & 100,0 & 73 & 100,0 \\
\hline
\end{tabular}

Verificou-se que $76,1 \%$ dos chefes do grupo I realizaram cursos para preparação para o trabalho desenvolvido no período da entrevista, em contraposição a apenas $22 \%$ e $25 \%$ dos chefes dos grupos II e IV respectivamente (tabela 13).

Tabela 13 - Distribuição dos chefes de família dos quatro novos grupos sociais segundo realização de curso preparatório para o trabalho. Santo André, SP, 2008.

\begin{tabular}{|c|c|c|c|c|c|c|c|c|c|c|}
\hline \multirow[b]{3}{*}{$\begin{array}{l}\text { Curso } \\
\text { preparatório } \\
\text { para } \\
\text { trabalho }\end{array}$} & \multicolumn{8}{|c|}{ GRUPO SOCIAL } & & \\
\hline & \multicolumn{2}{|c|}{$\mathbf{I}$} & \multicolumn{2}{|r|}{ II } & \multicolumn{2}{|c|}{ III } & \multicolumn{2}{|c|}{ IV } & \multicolumn{2}{|c|}{ Total } \\
\hline & $\mathbf{N}$ & $\%$ & $\mathbf{N}$ & $\%$ & $\mathbf{N}$ & $\%$ & $\mathbf{N}$ & $\%$ & $\mathbf{N}$ & $\%$ \\
\hline Sim & 108 & 76,1 & 54 & 22,0 & 2 & 16,7 & 20 & 25,0 & 184 & 38,4 \\
\hline Não & 33 & 23,2 & 188 & 76,7 & 10 & 83,3 & 59 & 73,8 & 290 & 60,5 \\
\hline Está cursando & 1 & 0,7 & 3 & 1,2 & 0 & 0,0 & 1 & 1,3 & 5 & 1,0 \\
\hline Total & 142 & 100,0 & 245 & 100,0 & 12 & 100,0 & 80 & 100,0 & $479 *$ & 100,0 \\
\hline
\end{tabular}

*Nota: Foram excluídos 110 chefes de família, a respeito dos quais não se obteve informação ou a variável não se aplicava.

Quanto ao registro em carteira, verificou-se que as famílias apresentam certa estabilidade no trabalho já que mais da metade dos trabalhadores das famílias dos grupos I, II e IV possuíam registro em carteira (tabela 14). Observa-se que no grupo 
III o número de chefes de família avaliados é pequeno relembrando que a grande parte desse grupo é composto por aposentados, pensionistas e afastados do trabalho.

Tabela 14 - Distribuição dos chefes de família dos quatro novos grupos sociais segundo registro em carteira. Santo André, SP, 2008.

\begin{tabular}{|c|c|c|c|c|c|c|c|c|c|c|}
\hline \multicolumn{11}{|c|}{ GRUPO SOCIAL } \\
\hline & \multicolumn{2}{|c|}{ I } & \multicolumn{2}{|c|}{ II } & \multicolumn{2}{|c|}{ III } & \multicolumn{2}{|c|}{ IV } & \multicolumn{2}{|c|}{ Total } \\
\hline $\begin{array}{l}\text { Registro } \\
\text { em carteira }\end{array}$ & $\mathbf{N}$ & $\%$ & $\mathbf{N}$ & $\%$ & $\mathbf{N}$ & $\%$ & $\mathbf{N}$ & $\%$ & $\mathbf{N}$ & $\%$ \\
\hline Sim & 94 & 66,2 & 151 & 60,6 & 4 & 33,3 & 52 & 63,4 & 301 & 62,1 \\
\hline Não & 48 & 33,8 & 98 & 39,4 & 8 & 66,7 & 30 & 36,6 & 184 & 37,9 \\
\hline Total & 142 & 100,0 & 249 & 100,0 & 12 & 100,0 & 82 & 100,0 & 485 & 100,0 \\
\hline
\end{tabular}

*Nota: Foram excluídos 104 chefes de família, a respeito dos quais não se obteve informação ou aos quais a variável não se aplicava.

Cerca de um quarto das famílias do grupo I recebem até um salário mínimo, sendo que quase metade das famílias do grupo II e mais da metade das famílias dos grupos III e IV recebem essa faixa salarial. Ressalta-se que mais de $16 \%$ das famílias do grupo I recebem mais de cinco salários mínimos o que não acontece com nenhuma família dos grupos III e IV (tabela 15).

Quanto ao setor de trabalho verifica-se que mais de $85 \%$ dos chefes de família trabalham no setor privado (tabela 16). 
Tabela 15 - Distribuição das famílias dos quatro novos grupos sociais segundo faixa de renda familiar per capita. Santo André, SP, 2008.

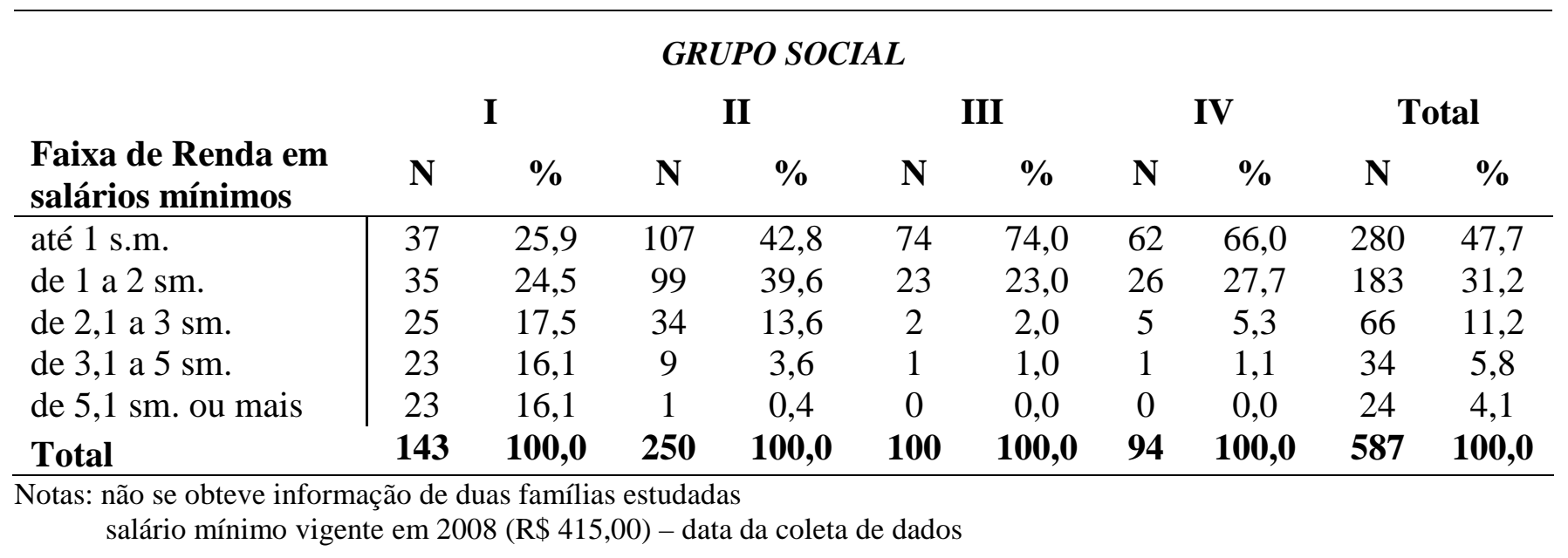

Tabela 16- Distribuição dos chefes de família dos quatro novos grupos sociais segundo setor de trabalho. Santo André, SP, 2008.

\begin{tabular}{|c|c|c|c|c|c|c|c|c|c|c|}
\hline \multirow[b]{3}{*}{$\begin{array}{l}\text { Setor de } \\
\text { trabalho }\end{array}$} & \multicolumn{8}{|c|}{ GRUPO SOCIAL } & & \\
\hline & \multicolumn{2}{|c|}{ I } & \multicolumn{2}{|c|}{ II } & \multicolumn{2}{|c|}{ III } & \multicolumn{2}{|c|}{ IV } & \multicolumn{2}{|c|}{ Total } \\
\hline & $\mathbf{N}$ & $\%$ & $\mathbf{N}$ & $\%$ & $\mathbf{N}$ & $\%$ & $\mathbf{N}$ & $\%$ & $\mathbf{N}$ & $\%$ \\
\hline Público & 17 & 11,9 & 29 & 11,6 & 1 & 10,0 & 10 & 12,3 & 57 & 11,8 \\
\hline Privado & 126 & 88,1 & 221 & 88,4 & 9 & 90,0 & 71 & 87,7 & 427 & 88,2 \\
\hline Total* & 143 & 100,0 & 250 & 100,0 & 10 & 100,0 & 81 & 100,0 & 484 & 100,0 \\
\hline
\end{tabular}

Nota: Foram excluídos 105 chefes de família, a respeito dos quais não se obteve informação ou a variável não se aplicava.

No que diz respeito ao tempo de serviço no emprego atual verificou-se que os chefes de família ativos do grupo I estavam trabalhando em média há 151,2 meses no mesmo emprego, os do grupo II há 102,2 meses, os do grupo III há 112,8 meses e os do grupo IV há 99,2 meses.

O tempo médio gasto pelos chefes para ir e voltar do trabalho ou da escola (desconsiderando-se os que trabalhavam no domicílio) foi de 77,3 minutos para o grupo I; 76,6 minutos para o II; 59,3 minutos para o grupo III e de 91,5 minutos para o grupo IV.

Em relação aos benefícios oriundos do trabalho verificou-se que em cada grupo social o conjunto dos que não recebiam era mais expressivo, ressaltando-se que para a maior parte do grupo III essa pergunta não se aplicava. Dos benefícios 
recebidos verificou-se que o vale-refeição era o mais preponderante seguido pela cesta-básica. Os benefícios abaixo foram citados como os mais relevantes pelos entrevistados (tabela 17).

Tabela 17 - Distribuição dos chefes dos quatro novos grupos sociais segundo benefício oriundo do trabalho. Santo André, SP, 2008.

\begin{tabular}{|c|c|c|c|c|c|c|c|c|c|c|}
\hline \multirow[b]{3}{*}{$\begin{array}{l}\text { Benefício } \\
\text { advindo do } \\
\text { trabalho }\end{array}$} & \multicolumn{8}{|c|}{ GRUPO SOCIAL } & & \\
\hline & \multicolumn{2}{|c|}{ I } & \multicolumn{2}{|c|}{ II } & \multicolumn{2}{|c|}{ III } & \multicolumn{2}{|c|}{ IV } & \multicolumn{2}{|c|}{ Total } \\
\hline & $\mathbf{N}$ & $\%$ & $\mathbf{N}$ & $\%$ & $\mathbf{N}$ & $\%$ & $\mathbf{N}$ & $\%$ & $\mathbf{N}$ & $\%$ \\
\hline $\begin{array}{l}\text { Cesta } \\
\text { básica }\end{array}$ & 25 & 17,9 & 41 & 16,5 & 2 & 13,3 & 21 & 25,6 & 89 & 18,3 \\
\hline $\begin{array}{l}\text { Vale } \\
\text { refeição }\end{array}$ & 28 & 20,0 & 49 & 19,7 & 0 & 0,0 & 15 & 18,3 & 92 & 18,9 \\
\hline $\begin{array}{l}\text { Vale } \\
\text { Supermerca } \\
\text { do }\end{array}$ & 4 & 2,9 & 5 & 2,0 & 0 & 0,0 & 5 & 6,1 & 14 & 2,9 \\
\hline Ass,Médica & 26 & 18,6 & 29 & 11,6 & 1 & 6,7 & 3 & 3,7 & 59 & 12,1 \\
\hline $\begin{array}{l}\text { Assistência } \\
\text { Odontológi } \\
\text { ca }\end{array}$ & 3 & 2,1 & 0 & 0,0 & 0 & 0,0 & 0 & 0,0 & 3 & 0,6 \\
\hline $\begin{array}{l}\text { Vale } \\
\text { transporte }\end{array}$ & 6 & 4,3 & 22 & 8,8 & 1 & 6,7 & 7 & 8,5 & 36 & 7,4 \\
\hline Não recebe & 48 & 34,3 & 103 & 41,4 & 11 & 73,3 & 31 & 37,8 & 193 & 39,7 \\
\hline Total* & 140 & 100,0 & 249 & 100,0 & 15 & 100,0 & 82 & 100,0 & 486 & 100,0 \\
\hline
\end{tabular}

Nota: Foram excluídos 103 chefes de família, a respeito dos quais não se obteve informação ou aos quais a variável não se aplicava.

\section{4- Formas de viver - dimensão do consumo}

Quanto às características de moradia verificou-se que para as famílias do grupo I a quase totalidade das casas era de alvenaria com acabamento. Já para as famílias do grupo IV o percentual estava em torno de 64\% (tabela 18). Verificou-se ainda que a maior parte das famílias nos quatro grupos morava em casas ou apartamentos isolados sendo que $19,1 \%$ das famílias do grupo IV viviam em favelas e 17,0\% em quintal comum (tabela 19). Ressalta-se que a grande parte das famílias do grupo I possuía casa própria em terreno regular ou irregular. Já as famílias do 
grupo II dividiam-se entre morar em casa própria ou alugada e também apresentaram maior percentual de famílias morando em casa cedida em comparação aos outros grupos (tabela 20). Em relação à isenção no pagamento do IPTU, nos grupos II e IV a proporção de famílias que não pagam o imposto foi maior do que no grupo III (tabela 21).

No que diz respeito a benefícios oriundos do governo ou sociedade civil, verificou-se que menos de $5 \%$ do total das famílias recebia o que dificulta sua comparação entre os grupos.

Tabela 18 - Distribuição das famílias dos quatro novos grupos sociais segundo material da habitação. Santo André, SP, 2008.

\section{GRUPO SOCIAL}

\section{I}

II

III

IV

Total

\begin{tabular}{lcccccccccc}
$\begin{array}{l}\text { Material } \\
\text { habitação }\end{array}$ & $\mathbf{d a}$ & $\mathbf{N}$ & $\mathbf{N}$ & $\mathbf{\%}$ & $\mathbf{N}$ & $\mathbf{\%}$ & $\mathbf{N}$ & $\mathbf{\%}$ & $\mathbf{N}$ & $\%$ \\
\hline $\begin{array}{l}\text { Alvenaria com } \\
\text { acabamento }\end{array}$ & 135 & 94,4 & 223 & 89,2 & 88 & 86,3 & 60 & 63,8 & 506 & 85,9 \\
$\begin{array}{l}\text { Alvenaria sem } \\
\text { acabamento }\end{array}$ & 8 & 5,6 & 26 & 10,4 & 13 & 12,7 & 28 & 29,8 & 75 & 12,7 \\
$\begin{array}{l}\text { Madeira } \\
\begin{array}{l}\text { Material } \\
\text { aproveitado }\end{array}\end{array}$ & 0 & 0,0 & 1 & 0,4 & 0 & 0,0 & 5 & 5,3 & 6 & 1,0 \\
$\begin{array}{l}\text { (papelão, } \\
\text { plástico) } \\
\text { Total }\end{array}$ & & 0,0 & 0 & 0,0 & 1 & 1,0 & 1 & 1,1 & 2 & 0,3 \\
& $\mathbf{1 4 3}$ & $\mathbf{1 0 0 , 0}$ & $\mathbf{2 5 0}$ & $\mathbf{1 0 0 , 0}$ & $\mathbf{1 0 2}$ & $\mathbf{1 0 0 , 0}$ & $\mathbf{9 4}$ & $\mathbf{1 0 0 , 0}$ & $\mathbf{5 8 9}$ & $\mathbf{1 0 0 , 0}$ \\
\hline
\end{tabular}


Tabela 19- Distribuição das famílias dos quatro novos grupos sociais segundo localização da moradia. Santo André, SP, 2008.

\begin{tabular}{|c|c|c|c|c|c|c|c|c|c|c|}
\hline \multirow[b]{3}{*}{$\begin{array}{l}\text { Localização } \\
\text { moradia }\end{array}$} & \multicolumn{8}{|c|}{ GRUPO SOCIAL } & & \\
\hline & \multicolumn{2}{|c|}{ I } & \multicolumn{2}{|c|}{ II } & \multicolumn{2}{|c|}{ III } & \multicolumn{2}{|c|}{ IV } & \multicolumn{2}{|c|}{ Total } \\
\hline & $\mathbf{N}$ & $\%$ & $\mathbf{N}$ & $\%$ & $\mathbf{N}$ & $\%$ & $\mathbf{N}$ & $\%$ & $\mathbf{N}$ & $\%$ \\
\hline Favela & 0 & 0,0 & 7 & 2,8 & 5 & 4,9 & 18 & 19,1 & 30 & 5,1 \\
\hline Cortiço & 0 & 0,0 & 2 & 0,8 & 0 & 0,0 & 2 & 2,1 & 4 & 0,7 \\
\hline Casa/apto & 139 & 97,2 & 214 & 85,6 & 87 & 85,3 & 57 & 60,6 & 497 & 84,4 \\
\hline $\begin{array}{l}\text { CDHU, } \\
\text { COHAB }\end{array}$ & 1 & 0,7 & 4 & 1,6 & 3 & 2,9 & 1 & 1,1 & 9 & 1,5 \\
\hline Quintal comum & 3 & 2,1 & 23 & 9,2 & 7 & 6,9 & 16 & 17,0 & 49 & 8,3 \\
\hline Total & 143 & 100,0 & 250 & 100,0 & 102 & 100,0 & 94 & 100,0 & 589 & 100,0 \\
\hline
\end{tabular}

Tabela 20 - Distribuição das famílias dos quatro novos grupos sociais segundo propriedade da residência. Santo André, SP, 2008.

\begin{tabular}{|c|c|c|c|c|c|c|c|c|c|c|}
\hline \multirow[b]{3}{*}{$\begin{array}{l}\text { Propriedade } \\
\text { da residência }\end{array}$} & \multicolumn{8}{|c|}{ GRUPO SOCIAL } & & \\
\hline & \multicolumn{2}{|c|}{ I } & \multicolumn{2}{|c|}{ II } & \multicolumn{2}{|c|}{ III } & \multicolumn{2}{|c|}{ IV } & \multicolumn{2}{|c|}{ Total } \\
\hline & $\mathbf{N}$ & $\%$ & $\mathbf{N}$ & $\%$ & $\mathbf{N}$ & $\%$ & $\mathbf{N}$ & $\%$ & $\mathbf{N}$ & $\%$ \\
\hline $\begin{array}{l}\text { Própria regular } \\
\text { ou irregular }\end{array}$ & 136 & 95,1 & 121 & 48,4 & 78 & 76,5 & 73 & 77,7 & 408 & 69,3 \\
\hline Alugada & 4 & 2,8 & 84 & 33,6 & 12 & 11,8 & 9 & 9,6 & 109 & 18,5 \\
\hline Cedida, Outros & 0 & 0,0 & 41 & 16,4 & 11 & 10,8 & 10 & 10,6 & 62 & 10,5 \\
\hline Financiada & 3 & 2,1 & 4 & 1,6 & 1 & 1,0 & 2 & 2,1 & 10 & 1,7 \\
\hline Total & 143 & 100.0 & 250 & 100.0 & 102 & 100.0 & 94 & 100.0 & 589 & 100.0 \\
\hline
\end{tabular}

Tabela 21 - Distribuição das famílias dos quatro novos grupos sociais segundo pagamento do IPTU. Santo André, SP, 2008.

\begin{tabular}{|c|c|c|c|c|c|c|c|c|c|c|}
\hline \multirow[b]{3}{*}{ Paga IPTU } & \multicolumn{8}{|c|}{ GRUPO SOCIAL } & & \\
\hline & \multicolumn{2}{|c|}{$\mathbf{I}$} & \multicolumn{2}{|c|}{ II } & \multicolumn{2}{|c|}{ III } & \multicolumn{2}{|c|}{ IV } & \multicolumn{2}{|c|}{ Total } \\
\hline & $\mathbf{N}$ & $\%$ & $\mathbf{N}$ & $\%$ & $\mathbf{N}$ & $\%$ & $\mathbf{N}$ & $\%$ & $\mathbf{N}$ & $\%$ \\
\hline Não & 0 & 0,0 & 87 & 34,8 & 22 & 21,6 & 38 & 40,4 & 147 & 25,0 \\
\hline Sim & 143 & 100,0 & 163 & 65,2 & 80 & 78,4 & 56 & 59,6 & 442 & 75,0 \\
\hline Total & 143 & 100,0 & 250 & 100,0 & 102 & 100,0 & 94 & 100,0 & 589 & 100,0 \\
\hline
\end{tabular}


As famílias do grupo I residiam em média há 12,2 anos no mesmo endereço, já as do grupo II moravam há 11,9 anos, as do grupo III há 17,2 anos e as famílias do grupo IV viviam em média 9,8 anos na mesma moradia. Ressaltando que as famílias do grupo 3 são aquelas que apresentam chefes de família mais velhos e maior proporção de chefes aposentados.

Ao se verificar o motivo de mudança de moradia nos últimos 5 anos identificou-se que para os grupos I e III, a principal causa foi a melhora das condições financeiras, para o grupo II foi casamento/separação e para o grupo IV as causas foram melhora de infraestrutura e casamento/separação (tabela 22).

Tabela 22 - Distribuição das famílias dos quatro novos grupos sociais segundo motivo de mudança nos últimos cinco anos. Santo André, SP, 2008.

\begin{tabular}{|c|c|c|c|c|c|c|c|c|c|c|}
\hline \multirow[b]{3}{*}{$\begin{array}{l}\text { Motivo } \\
\text { mudança }\end{array}$} & \multicolumn{8}{|c|}{ GRUPO SOCIAL } & & \\
\hline & \multicolumn{2}{|c|}{$\mathbf{I}$} & \multicolumn{2}{|c|}{ II } & \multicolumn{2}{|c|}{ III } & \multicolumn{2}{|c|}{ IV } & \multicolumn{2}{|c|}{ Total } \\
\hline & $\mathbf{N}$ & $\%$ & $\mathbf{N}$ & $\%$ & $\mathbf{N}$ & $\%$ & $\mathbf{N}$ & $\%$ & $\mathbf{N}$ & $\%$ \\
\hline $\begin{array}{l}\text { Transferência } \\
\text { de emprego }\end{array}$ & 5 & 13,5 & 8 & 8,9 & 0 & 0,0 & 1 & 3,0 & 14 & 7,9 \\
\hline $\begin{array}{l}\text { Transferência } \\
\text { de escola }\end{array}$ & 0 & 0,0 & 1 & 1,1 & 0 & 0,0 & 0 & 0,0 & 1 & 0,6 \\
\hline Segurança & 2 & 5,4 & 1 & 1,1 & 0 & 0,0 & 1 & 3,0 & 4 & 2,2 \\
\hline $\begin{array}{l}\text { Casamento/ } \\
\text { Separação }\end{array}$ & 2 & 5,4 & 23 & 25,6 & 3 & 16,7 & 8 & 24,2 & 36 & 20,2 \\
\hline $\begin{array}{l}\text { Piora das } \\
\text { condições } \\
\text { financeiras }\end{array}$ & 4 & 10,8 & 10 & 11,1 & 1 & 5,6 & 4 & 12,1 & 19 & 10,7 \\
\hline $\begin{array}{l}\text { Melhora de } \\
\text { condições } \\
\text { financeiras }\end{array}$ & 15 & 40,5 & 21 & 23,3 & 6 & 33,3 & 4 & 12,1 & 46 & 25,8 \\
\hline $\begin{array}{l}\text { Melhora da } \\
\text { Infra-estrutura }\end{array}$ & 6 & 16,2 & 16 & 17,8 & 5 & 27,8 & 8 & 24,2 & 35 & 19,7 \\
\hline Outro & 3 & 8,1 & 10 & 11,1 & 3 & 16,7 & 7 & 21,2 & 23 & 12,9 \\
\hline Total & 37 & 100,0 & 90 & 100,0 & 18 & 100,0 & 33 & 100,0 & 178 & 100,0 \\
\hline
\end{tabular}

Nota: Foram excluídos 411 chefes de família, a respeito dos quais não se obteve informação ou aos quais a variável não se aplicava.

Quanto à posse de bens e serviços verificou-se que o grupo IV era o que apresentava piores condições de posse em contraposição ao grupo I (Quadro 9). 
No que diz respeito ao acesso aos serviços de saneamento básico, identificouse que a o grupo IV foi o único a não ter a totalidade das famílias com acesso à água, luz, e esgoto (tabelas 23, 24 e 25). Ressalta-se inclusive que a maior parte das famílias do grupo IV não tinham acesso à esgoto encanado (tabela 26). Quanto à coleta de lixo, todo o grupo I e a quase totalidade dos outros três grupos tinham acesso à coleta por caminhões de lixo (tabela 27). Quando se verificou a legalidade do acesso à água e luz observou-se que os grupos I, II e III recebiam quase que na totalidade a conta desses serviços, enquanto que a proporção diminuiu bastante no grupo IV (tabelas 28 e 29). 
Quadro 9 - Distribuição das famílias dos quatro grupos sociais segundo posse de bens e presença de empregados mensalistas no domicílio. Santo André, SP, 2008.

\begin{tabular}{|c|c|c|c|c|c|c|c|c|}
\hline \multicolumn{9}{|c|}{ GRUPO SOCIAL } \\
\hline & \multicolumn{2}{|c|}{$\mathbf{I}$} & \multicolumn{2}{|c|}{ II } & \multicolumn{2}{|c|}{ III } & \multicolumn{2}{|c|}{ IV } \\
\hline & $\mathbf{N}$ & $\%$ & $\mathbf{N}$ & $\%$ & $\mathbf{N}$ & $\%$ & $\mathbf{N}$ & $\%$ \\
\hline \multicolumn{9}{|c|}{ Rádio/aparelho de Som } \\
\hline Não tem & 6 & 4,2 & 28 & 11,2 & 4 & 3,9 & 9 & 9,6 \\
\hline 1 ou 2 & 91 & 63,6 & 199 & 79,6 & 81 & 79,4 & 76 & 80,9 \\
\hline 3 ou mais & 46 & 32,2 & 23 & 9,2 & 17 & 16,7 & 9 & 9,6 \\
\hline \multicolumn{9}{|l|}{ TV } \\
\hline Não tem & 0 & 0,0 & 2 & 0,8 & 3 & 2,9 & 0 & 0,0 \\
\hline 1 ou 2 & 63 & 44,1 & 187 & 74,8 & 65 & 63,7 & 82 & 87,2 \\
\hline 3 ou mais & 80 & 55,9 & 61 & 24,4 & 34 & 33,3 & 12 & 12,8 \\
\hline \multicolumn{9}{|l|}{ Banheiro } \\
\hline 1 ou 2 & 90 & 62,9 & 239 & 95,6 & 90 & 88,2 & 92 & 97,9 \\
\hline 3 ou mais & 53 & 37,1 & 11 & 4,4 & 12 & 11,8 & 2 & 2,1 \\
\hline \multicolumn{9}{|c|}{ Automóvel } \\
\hline Não tem & 20 & 14,0 & 127 & 50,8 & 38 & 37,3 & 52 & 55,3 \\
\hline 1 ou 2 & 105 & 73,4 & 117 & 46,8 & 59 & 57,8 & 42 & 44,7 \\
\hline 3 ou mais & 18 & 12,6 & 6 & 2,4 & 5 & 4,9 & 0 & 0,0 \\
\hline \multicolumn{9}{|c|}{ Aspirador de pó } \\
\hline Não & 32 & 22,4 & 179 & 71,6 & 58 & 56,9 & 73 & 77,7 \\
\hline Sim & 111 & 77,6 & 71 & 28,4 & 44 & 43,1 & 21 & 22,3 \\
\hline \multicolumn{9}{|c|}{ Máquina de lavar roupa } \\
\hline Não & 3 & 2,1 & 43 & 17,2 & 11 & 10,8 & 18 & 19,1 \\
\hline Sim & 140 & 97,9 & 207 & 82,8 & 91 & 89,2 & 76 & 80,9 \\
\hline \multicolumn{9}{|c|}{ Vídeo/DVD } \\
\hline Não tem & 2 & 1,4 & 24 & 9,6 & 15 & 14,7 & 11 & 11,7 \\
\hline 1 ou 2 & 118 & 82,5 & 220 & 88,0 & 83 & 81,4 & 83 & 88,3 \\
\hline 3 ou mais & 23 & 16,1 & 6 & 2,4 & 4 & 3,9 & 0 & 0,0 \\
\hline \multicolumn{9}{|l|}{ Geladeira } \\
\hline Não & 64 & 44,8 & 80 & 32,0 & 42 & 41,2 & 24 & 25,5 \\
\hline Sim & 79 & 55,2 & 170 & 68,0 & 60 & 58,8 & 70 & 74,5 \\
\hline \multicolumn{9}{|c|}{ Geladeira duplex } \\
\hline Não & 68 & 47,9 & 167 & 67,1 & 57 & 55,9 & 71 & 75,5 \\
\hline Sim & 74 & 52,1 & 82 & 32,9 & 45 & 44,1 & 23 & 24,5 \\
\hline \multicolumn{9}{|l|}{ Freezer } \\
\hline Não & 91 & 63,6 & 212 & 84,8 & 90 & 88,2 & 82 & 87,2 \\
\hline \multirow{2}{*}{\multicolumn{9}{|c|}{ Computador }} \\
\hline & & & & & & & & \\
\hline Não & 9 & 6,3 & 91 & 36,4 & 26 & 25,5 & 59 & 62,8 \\
\hline 1 & 97 & 67,8 & 147 & 58,8 & 71 & 69,6 & 34 & 36,2 \\
\hline 2 ou mais & 37 & 25,9 & 12 & 4,8 & 5 & 4,9 & 1 & 1,1 \\
\hline \multicolumn{9}{|c|}{ Computador com internet } \\
\hline Não & 17 & 11,9 & 122 & 48,8 & 36 & 35,3 & 67 & 71,3 \\
\hline 1 & 107 & 74,8 & 124 & 49,6 & 64 & 62,7 & 26 & 27,7 \\
\hline 2 ou mais & 19 & 13,3 & 4 & 1,6 & 2 & 2,0 & 1 & 1,1 \\
\hline \multicolumn{9}{|c|}{ Cômodos para dormir } \\
\hline Não tem & 0 & 0,0 & 0 & 0,0 & 1 & 1,0 & 1 & 1,1 \\
\hline 1 & 1 & 0,7 & 68 & 27,2 & 8 & 7,8 & 23 & 24,5 \\
\hline 2 & 30 & 21,0 & 141 & 56,4 & 47 & 46,1 & 45 & 47,9 \\
\hline 3 & 96 & 67,1 & 33 & 13,2 & 34 & 33,3 & 23 & 24,5 \\
\hline 4 ou mais & 16 & 11,2 & 8 & 3,2 & 12 & 11,8 & 2 & 2,1 \\
\hline Empregad & & & & & & & & \\
\hline Não & 111 & 78,2 & 244 & 97,6 & 95 & 93,1 & 94 & 100,0 \\
\hline Sim & 31 & 21,8 & 6 & 2,4 & 7 & 6,9 & 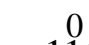 & 0,0 \\
\hline
\end{tabular}


Tabela 23 - Distribuição das famílias dos quatro novos grupos sociais segundo acesso à água. Santo André, SP, 2008.

\begin{tabular}{|c|c|c|c|c|c|c|c|c|c|c|}
\hline \multirow[b]{3}{*}{$\begin{array}{l}\text { Acesso } \\
\text { à água }\end{array}$} & \multicolumn{8}{|c|}{ GRUPO SOCIAL } & & \\
\hline & \multicolumn{2}{|c|}{ I } & \multicolumn{2}{|c|}{ II } & \multicolumn{2}{|c|}{ III } & \multicolumn{2}{|c|}{ IV } & \multicolumn{2}{|c|}{ Total } \\
\hline & $\mathbf{N}$ & $\%$ & $\mathbf{N}$ & $\%$ & $\mathbf{N}$ & $\%$ & $\mathbf{N}$ & $\%$ & $\mathbf{N}$ & $\%$ \\
\hline Não & 0 & 0,0 & 0 & 0,0 & 0 & 0,0 & 17 & 18,1 & 17 & 2,9 \\
\hline Sim & 143 & 100,0 & 250 & 100,0 & 102 & 100,0 & 77 & 81,9 & 572 & 97,1 \\
\hline Total & 143 & 100,0 & 250 & 100,0 & 102 & 100,0 & 94 & 100,0 & 589 & 100,0 \\
\hline
\end{tabular}

Tabela 24 - Distribuição das famílias dos quatro novos grupos sociais segundo acesso à luz. Santo André, SP, 2008.

\begin{tabular}{|c|c|c|c|c|c|c|c|c|c|c|}
\hline \multirow{3}{*}{$\begin{array}{l}\text { Acesso } \\
\text { à luz }\end{array}$} & \multicolumn{8}{|c|}{ GRUPO SOCIAL } & \multirow{2}{*}{\multicolumn{2}{|c|}{ Total }} \\
\hline & \multicolumn{2}{|c|}{ I } & \multicolumn{2}{|c|}{ II } & \multicolumn{2}{|c|}{ III } & \multicolumn{2}{|c|}{ IV } & & \\
\hline & $\mathbf{N}$ & $\%$ & $\mathbf{N}$ & $\%$ & $\mathbf{N}$ & $\%$ & $\mathbf{N}$ & $\%$ & $\mathbf{N}$ & $\%$ \\
\hline Não & 0 & 0.0 & 0 & 0.0 & 1 & 1.0 & 10 & 10.6 & 11 & 1.9 \\
\hline Sim & 143 & 100.0 & 250 & 100.0 & 101 & 99.0 & 84 & 89.4 & 578 & 98.1 \\
\hline Total & 143 & 100.0 & 250 & 100.0 & 102 & 100.0 & 94 & 100.0 & 589 & 100.0 \\
\hline
\end{tabular}

Tabela 25 - Distribuição das famílias dos quatro novos grupos sociais segundo acesso a esgoto. Santo André, SP, 2008.

\begin{tabular}{|c|c|c|c|c|c|c|c|c|c|c|}
\hline \multirow[b]{3}{*}{$\begin{array}{l}\text { Acesso } \\
\text { a } \\
\text { esgoto }\end{array}$} & \multicolumn{8}{|c|}{ GRUPO SOCIAL } & \multirow{2}{*}{\multicolumn{2}{|c|}{ Total }} \\
\hline & \multicolumn{2}{|c|}{ I } & \multicolumn{2}{|c|}{ II } & \multicolumn{2}{|c|}{ III } & \multicolumn{2}{|c|}{ IV } & & \\
\hline & $\mathbf{N}$ & $\%$ & $\mathbf{N}$ & $\%$ & $\mathbf{N}$ & $\%$ & $\mathbf{N}$ & $\%$ & $\mathbf{N}$ & $\%$ \\
\hline Não & 0 & 0,0 & 0 & 0,0 & 0 & 0,0 & 76 & 80,9 & 76 & 12,9 \\
\hline Sim & 143 & 100,0 & 250 & 100,0 & 102 & 100,0 & 18 & 19,1 & 513 & 87,1 \\
\hline Total & 143 & 100,0 & 250 & 100,0 & 102 & 100,0 & 94 & 100,0 & 589 & 100,0 \\
\hline
\end{tabular}


Tabela 26 - Distribuição das famílias dos quatro novos grupos sociais segundo destino do esgoto. Santo André, SP, 2008.

\begin{tabular}{|c|c|c|c|c|c|c|c|c|c|c|}
\hline \multirow[b]{3}{*}{$\begin{array}{l}\text { Destino } \\
\text { esgoto }\end{array}$} & \multicolumn{8}{|c|}{ GRUPO SOCIAL } & \multirow{2}{*}{\multicolumn{2}{|c|}{ Total }} \\
\hline & \multicolumn{2}{|c|}{ I } & \multicolumn{2}{|c|}{ II } & \multicolumn{2}{|c|}{ III } & \multicolumn{2}{|c|}{ IV } & & \\
\hline & $\mathbf{N}$ & $\%$ & $\mathbf{N}$ & $\%$ & $\mathbf{N}$ & $\%$ & $\mathbf{N}$ & $\%$ & $\mathbf{N}$ & $\%$ \\
\hline Fossa séptica & 0 & 0,0 & 0 & 0,0 & 0 & 0,0 & 57 & 64,0 & 57 & 9,8 \\
\hline Manancial & 0 & 0,0 & 0 & 0,0 & 0 & 0,0 & 7 & 7,9 & 7 & 1,2 \\
\hline Rio & 0 & 0,0 & 0 & 0,0 & 0 & 0,0 & 8 & 9,0 & 8 & 1,4 \\
\hline Serviços públicos & 143 & 100,0 & 250 & 100,0 & 102 & 100,0 & 17 & 19,1 & 512 & 87,7 \\
\hline Total & 143 & 100,0 & 250 & 100,0 & 102 & 100,0 & 89 & 100,0 & 584 & 100,0 \\
\hline
\end{tabular}

Tabela 27 - Distribuição das famílias dos quatro novos grupos sociais segundo destino do lixo. Santo André, SP, 2008.

\section{GRUPO SOCIAL}

\begin{tabular}{|c|c|c|c|c|c|c|c|c|c|c|}
\hline \multirow[b]{2}{*}{$\begin{array}{l}\text { Destino do } \\
\text { lixo }\end{array}$} & \multicolumn{2}{|c|}{ I } & \multicolumn{2}{|c|}{ II } & \multicolumn{2}{|c|}{ III } & \multicolumn{2}{|c|}{ IV } & \multicolumn{2}{|c|}{ Total } \\
\hline & $\mathbf{N}$ & $\%$ & $\mathbf{N}$ & $\%$ & $\mathbf{N}$ & $\%$ & $\mathbf{N}$ & $\%$ & $\mathbf{N}$ & $\%$ \\
\hline $\begin{array}{l}\text { Via pública/ } \\
\text { terreno } \\
\text { baldio }\end{array}$ & 0 & 0,0 & 3 & 1,2 & 1 & 1,0 & 3 & 3,2 & 7 & 1,2 \\
\hline $\begin{array}{l}\text { Caminhão } \\
\text { de lixo }\end{array}$ & 143 & 100,0 & 245 & 98,4 & 101 & 99,0 & 89 & 95,7 & 578 & 98,6 \\
\hline Queima & 0 & 0,0 & 1 & 0,4 & 0 & 0,0 & 0 & 0,0 & 0 & 0,0 \\
\hline Outros & 0 & 0,0 & 0 & 0,0 & 0 & 0,0 & 1 & 1,1 & 1 & 0,2 \\
\hline Total & 143 & 100,0 & 249 & 100,0 & 102 & 100,0 & 93 & 100,0 & $586 *$ & 100,0 \\
\hline
\end{tabular}

Tabela 28 - Distribuição das famílias dos quatro novos grupos sociais segundo recebimento de conta de água. Santo André, SP, 2008.

\begin{tabular}{|c|c|c|c|c|c|c|c|c|c|c|}
\hline \multirow[b]{3}{*}{$\begin{array}{l}\text { Recebe } \\
\text { conta de } \\
\text { água }\end{array}$} & \multicolumn{8}{|c|}{ GRUPO SOCIAL } & & \\
\hline & \multicolumn{2}{|c|}{ I } & \multicolumn{2}{|c|}{ II } & \multicolumn{2}{|c|}{ III } & \multicolumn{2}{|c|}{ IV } & \multicolumn{2}{|c|}{ Total } \\
\hline & $\mathbf{N}$ & $\%$ & $\mathbf{N}$ & $\%$ & $\mathbf{N}$ & $\%$ & $\mathbf{N}$ & $\%$ & $\mathbf{N}$ & $\%$ \\
\hline Sim & 143 & 100,0 & 244 & 97,6 & 102 & 100,0 & 58 & 61,7 & 547 & 92,9 \\
\hline Não & 0 & 0,0 & 6 & 2,4 & 0 & 0,0 & 36 & 38,3 & 42 & 7,1 \\
\hline Total & 143 & 100,0 & 250 & 100,0 & 102 & 100,0 & 94 & 100,0 & 589 & 100,0 \\
\hline
\end{tabular}


Tabela 29 - Distribuição das famílias dos quatro novos grupos sociais segundo recebimento de conta de luz. Santo André, SP, 2008.

\begin{tabular}{|c|c|c|c|c|c|c|c|c|c|c|}
\hline \multirow[b]{3}{*}{$\begin{array}{l}\text { Recebe } \\
\text { conta de } \\
\text { luz }\end{array}$} & \multicolumn{8}{|c|}{ GRUPO SOCIAL } & & \\
\hline & \multicolumn{2}{|c|}{ I } & \multicolumn{2}{|c|}{ II } & \multicolumn{2}{|c|}{ III } & \multicolumn{2}{|c|}{ IV } & \multicolumn{2}{|c|}{ Total } \\
\hline & $\mathbf{N}$ & $\%$ & $\mathbf{N}$ & $\%$ & $\mathbf{N}$ & $\%$ & $\mathbf{N}$ & $\%$ & $\mathbf{N}$ & $\%$ \\
\hline Sim & 143 & 100,0 & 250 & 100,0 & 101 & 99,0 & 64 & 68,1 & 558 & 94,7 \\
\hline Não & 0 & 0,0 & 0 & 0,0 & 1 & 1,0 & 30 & 31,9 & 31 & 5,3 \\
\hline Total & 143 & 100,0 & 250 & 100,0 & 102 & 100,0 & 94 & 100,0 & 589 & 100,0 \\
\hline
\end{tabular}

Mais de $70 \%$ das famílias do grupo I possuíam membros que utilizavam o automóvel como meio de transporte em contraposição às do grupo IV, em que apenas um terço das famílias fazia uso desse meio de locomoção. Ônibus foi o meio de transporte mais freqüente entre os membros das famílias dos grupos II, III e IV. Para as do grupo IV o ônibus perde apenas para o meio de transporte "a pé" que foi citado por quase $78 \%$ das famílias. Ressalta-se que nesse item poderia ser dada mais de uma resposta (Quadro 10).

Quadro 10- Porcentual das famílias dos quatro grupos sociais segundo meios de transporte utilizados pelos seus membros para ir ao trabalho/escola. Santo André, SP, 2008 .

\begin{tabular}{|c|c|c|c|c|}
\hline \multicolumn{5}{|c|}{ GRUPO SOCIAL } \\
\hline $\begin{array}{ll}\text { Meio de } \\
\text { transporte }\end{array}$ & $\begin{array}{l}\text { I } \\
\%\end{array}$ & II & $\underset{\%}{\text { III }}$ & $\begin{array}{l}\text { IV } \\
\%\end{array}$ \\
\hline Trem & 21,0 & 17,6 & 21,6 & 13,8 \\
\hline Ônibus & 64,3 & 76,0 & 66,7 & 73,4 \\
\hline Automóvel & 76,8 & 41,0 & 41,2 & 37,2 \\
\hline Metrô & 15,4 & 11,2 & 14,7 & 11,7 \\
\hline Bicicleta & 9,1 & 12,4 & 5,9 & 12,8 \\
\hline Moto & 10,5 & 8,4 & 7,8 & 11,7 \\
\hline Fretado & 12,6 & 10,4 & 9,8 & 5,3 \\
\hline Perua escolar & 8,4 & 4,8 & 3,9 & 11,7 \\
\hline A pé & 67,1 & 72,0 & 60,8 & 77,7 \\
\hline Outros & 1,4 & 0,4 & 0,0 & 0,0 \\
\hline
\end{tabular}

Nota: Cada família pode ter referido mais de um meio de transporte 
As atividades de lazer se distribuíram diferentemente pelos grupos sociais. A referência a atividades como ler e fazer viagens diminuem nos grupos III e IV. Chama a atenção que a ida a cultos foi muito citada pelas famílias do grupo IV (Quadro 11).

Quadro 11 - Porcentual de famílias dos quatro grupos sociais segundo atividades de lazer. Santo André, SP, 2008.

\begin{tabular}{|lcccc|}
\hline $\begin{array}{l}\text { Atividades de lazer } \\
\text { da família* }\end{array}$ & I & GRUPO SOCIAL & III & IV \\
& \% & \% & \% & \% \\
\hline Atividade física & 78,3 & 54,0 & 66,7 & 50,0 \\
Leitura & 79,7 & 65,6 & 68,6 & 69,1 \\
Tv/Vídeo & 97,9 & 95,6 & 95,1 & 96,8 \\
Cinema & 79,0 & 53,2 & 57,8 & 40,4 \\
Teatro & 40,6 & 17,6 & 22,5 & 11,7 \\
Viagem & 76,2 & 52,0 & 60,8 & 42,6 \\
Visitas a parques & 60,8 & 64,8 & 55,9 & 61,7 \\
Visitas a amigos e & 86,0 & 82,8 & 87,3 & 79,8 \\
parentes & & & & \\
Festas & 86,0 & 80,4 & 86,3 & 74,5 \\
Internet & 93,7 & 73,6 & 77,5 & 52,1 \\
Cultos & 65,7 & 46,0 & 67,6 & 71,3 \\
Outros & 5,6 & 6,8 & 3,9 & 6,4 \\
\hline
\end{tabular}

Nota: Cada família pode ter referido mais de uma atividade de lazer

Os riscos a que as famílias se sentiam expostas estão apresentados no quadro 12. Observa-se que a violência foi o risco mais citado nos grupos I, II, III. Já no grupo IV os riscos mais citados foram envolvimento com problemas decorrentes do tráfico de drogas e contatos com vetores (ratos e insetos). 
Quadro 12 - Porcentual de famílias que declararam estar expostas a algum tipo de risco. Santo André, SP, 2008.

\begin{tabular}{|c|c|c|c|c|c|c|c|c|}
\hline \multicolumn{9}{|c|}{ GRUPO SOCIAL } \\
\hline \multirow[t]{2}{*}{$\begin{array}{l}\text { Riscos a que se sentem } \\
\text { expostos }\end{array}$} & \multicolumn{2}{|c|}{ I } & \multicolumn{2}{|c|}{ II } & \multicolumn{2}{|c|}{ III } & \multicolumn{2}{|c|}{ IV } \\
\hline & $\mathbf{N}$ & $\%$ & $\mathbf{N}$ & $\%$ & $\mathbf{N}$ & $\%$ & $\mathbf{N}$ & $\%$ \\
\hline Desmoronamento & 4 & 2,8 & 12 & 4,8 & 5 & 4,9 & 14 & 14,9 \\
\hline Enchente & 3 & 2,1 & 4 & 1,6 & 4 & 3,9 & 9 & 9,6 \\
\hline Violência & 96 & 67,1 & 150 & 60,0 & 74 & 72,5 & 50 & 53,2 \\
\hline Acidente de trânsito & 54 & 37,8 & 93 & 37,2 & 43 & 42,2 & 32 & 34,0 \\
\hline $\begin{array}{l}\text { Contaminação (lixo, } \\
\text { esgoto, córregos) }\end{array}$ & 8 & 5,6 & 33 & 13,2 & 18 & 17,6 & 37 & 39,4 \\
\hline $\begin{array}{l}\text { Contato com vetores } \\
\text { (ratos e insetos) }\end{array}$ & 45 & 31,5 & 102 & 40,8 & 52 & 51,0 & 64 & 68,1 \\
\hline $\begin{array}{l}\text { Risco de consumo de } \\
\text { drogas (inclusive } \\
\text { alcoolismo) }\end{array}$ & 66 & 46,2 & 138 & 55,2 & 58 & 56,9 & 58 & 61,7 \\
\hline $\begin{array}{l}\text { Envolvimento com } \\
\text { problemas decorrentes do } \\
\text { tráfico de drogas }\end{array}$ & 32 & 22,4 & 54 & 21,6 & 31 & 30,4 & 36 & 38,3 \\
\hline Outros & 4 & 2,8 & 4 & 1,6 & 5 & 4,9 & 4 & 4,3 \\
\hline
\end{tabular}

Nota: Cada família pode ter referido mais de um risco

Ao avaliar a rede de apoio social identificou-se que a participação das famílias dos quatro grupos é pequena e concentra-se em atividades sociais ligadas à igreja principalmente nos grupos I e III, excluindo-se frequência a cultos ou missas (quadro 13). Referências à participação em conselhos de bairro, partido político, ONG's e voluntariado praticamente não ocorreram.

Quadro 13- Percentual de famílias dos quatro grupos sociais que relataram alguma forma de participação social. Santo André, SP, 2008.

\begin{tabular}{|c|c|c|c|c|c|c|c|c|}
\hline \multicolumn{9}{|c|}{ GRUPO SOCIAL } \\
\hline \multirow[b]{2}{*}{ Participação social em } & \multicolumn{2}{|c|}{ I } & \multicolumn{2}{|c|}{ II } & \multicolumn{2}{|c|}{ III } & \multicolumn{2}{|c|}{ IV } \\
\hline & $\mathbf{N}$ & $\%$ & $\mathbf{N}$ & $\%$ & $\mathbf{N}$ & $\%$ & $\mathbf{N}$ & $\%$ \\
\hline Escola & 6 & 4,2 & 18 & 7,2 & 3 & 2,9 & 1 & 1,0 \\
\hline Sindicato/Associação & 14 & 9,8 & 13 & 5,2 & 10 & 9,8 & 4 & 4,2 \\
\hline Ligadas à religião & 27 & 18,9 & 34 & 13,6 & 20 & 19,6 & 9 & 9,5 \\
\hline
\end{tabular}


No que diz respeito à utilização de instituições sociais pelas famílias nos bairros, verificou-se que as principais eram a escola, os grupos ligados às igrejas e os equipamentos ligados à saúde. (Quadro 14).

Quadro 14- Percentual de famílias dos quatro grupos sociais que relataram a utilização de instituições . Santo André, SP, 2008.

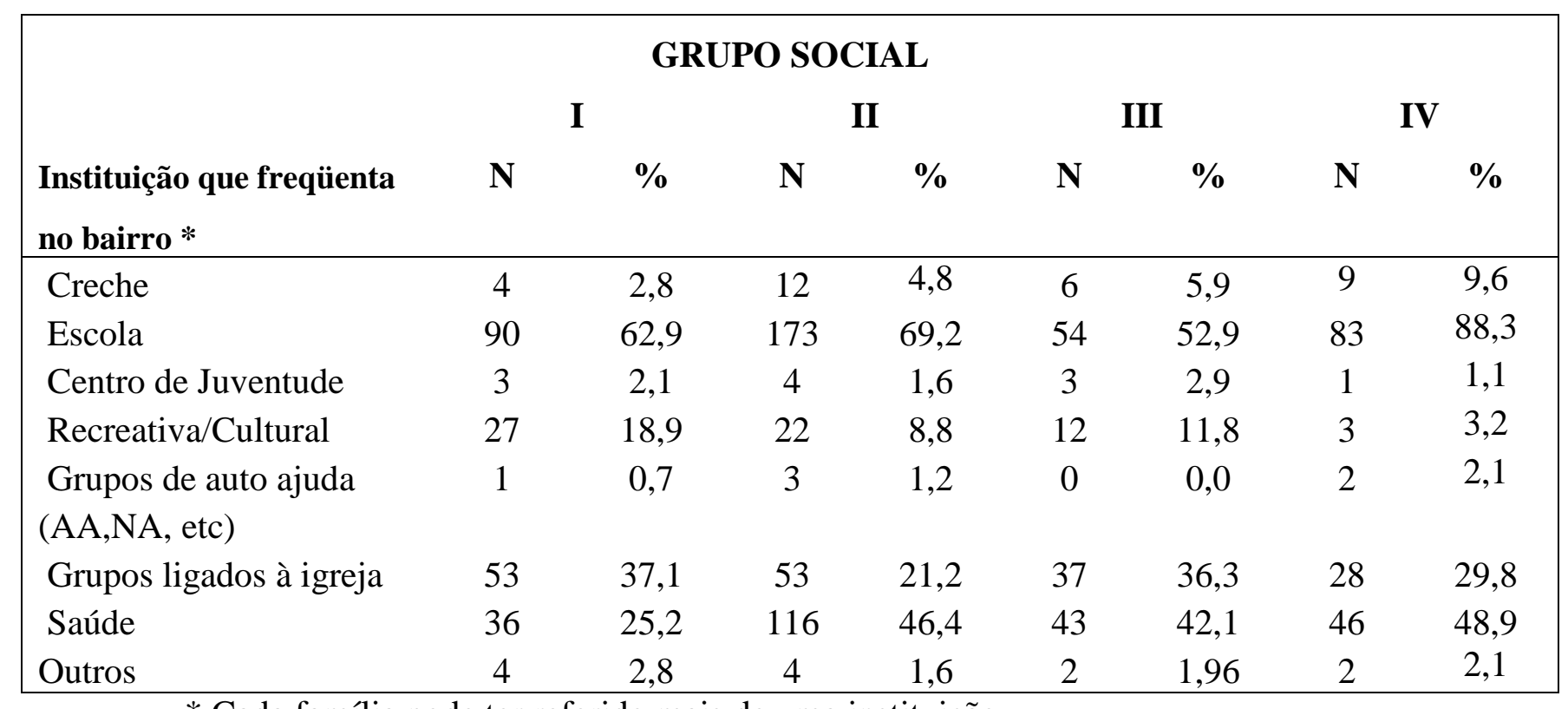

* Cada família pode ter referido mais de uma instituição

Ao se pesquisar a suficiência ou não de renda para gastos com alimentação e vestuário e a possibilidade de se guardar dinheiro, notou-se que no grupo IV a proporção de famílias que conseguem guardar dinheiro é menor que nos outros três (tabela 30). Entretanto mais de um quarto das famílias do grupo I relataram conseguir guardar dinheiro justificando o fato de que mais da metade desse grupo conseguiam realizar aplicações ou fazer poupança (tabela 31 ) e que apenas $11,4 \%$ dessas famílias tinham dívidas (tabela 32). Nota-se que cerca de $60 \%$ das famílias pertencentes ao grupo IV apresentaram gastos com crediários e empréstimos. O grupo III, por sua vez, é o que apresenta menor porcentagem de famílias com esse tipo de gasto (tabela 33). 
Tabela 30- Distribuição das famílias dos quatro novos grupos sociais segundo suficiência da renda para arcar com despesas básicas (alimentação, vestuário, contas de água e de luz). Santo André, SP, 2008.

\begin{tabular}{|c|c|c|c|c|c|c|c|c|c|c|c|}
\hline \multirow[b]{3}{*}{$\begin{array}{l}\text { Renda } \\
\text { família }\end{array}$} & \multirow[b]{3}{*}{ da } & \multicolumn{8}{|c|}{ GRUPO SOCIAL } & & \\
\hline & & \multicolumn{2}{|c|}{$\mathbf{I}$} & \multicolumn{2}{|c|}{ II } & \multicolumn{2}{|c|}{ III } & \multicolumn{2}{|c|}{ IV } & \multicolumn{2}{|c|}{ Total } \\
\hline & & $\mathbf{N}$ & $\%$ & $\mathbf{N}$ & $\%$ & $\mathbf{N}$ & $\%$ & $\mathbf{N}$ & $\%$ & $\mathbf{N}$ & $\%$ \\
\hline Suficiente & & 73 & 51,0 & 113 & 45,2 & 40 & 39,2 & 35 & 37,2 & 261 & 44,3 \\
\hline Insuficiente & & 31 & 21,7 & 109 & 43,6 & 48 & 47,1 & 51 & 54,3 & 239 & 40,6 \\
\hline $\begin{array}{l}\text { Suficiente } \\
\text { sobra } \\
\text { guardar }\end{array}$ & $\begin{array}{r}\mathrm{e} \\
\text { para }\end{array}$ & 39 & 27,3 & 28 & 11,2 & 14 & 13,7 & 8 & 8,5 & 89 & 15,1 \\
\hline Total & & 143 & 100,0 & 250 & 100,0 & 102 & $\mathbf{1 0 0 , 0}$ & 94 & $\mathbf{1 0 0 , 0}$ & 589 & 100,0 \\
\hline
\end{tabular}

Tabela 31- Distribuição das famílias dos quatro novos grupos sociais segundo posse de poupança ou aplicações financeiras. Santo André, SP, 2008.

\begin{tabular}{|c|c|c|c|c|c|c|c|c|c|c|}
\hline \multirow[b]{3}{*}{$\begin{array}{l}\text { Poupança } \\
\text { ou } \\
\text { aplicações }\end{array}$} & \multicolumn{8}{|c|}{ GRUPO SOCIAL } & \multirow{2}{*}{\multicolumn{2}{|c|}{ Total }} \\
\hline & \multicolumn{2}{|c|}{ I } & \multicolumn{2}{|c|}{ II } & \multicolumn{2}{|c|}{ III } & \multicolumn{2}{|c|}{ IV } & & \\
\hline & $\mathbf{N}$ & $\%$ & $\mathbf{N}$ & $\%$ & $\mathbf{N}$ & $\%$ & $\mathbf{N}$ & $\%$ & $\mathbf{N}$ & $\%$ \\
\hline Sim & 85 & 61,2 & 76 & 31,5 & 37 & 36,6 & 26 & 27,7 & 224 & 39,0 \\
\hline Não & 54 & 38,8 & 165 & 68,5 & 64 & 63,4 & 68 & 72,3 & 351 & 61,0 \\
\hline Total & 139 & 100,0 & 241 & 100,0 & 101 & 100,0 & 94 & 100,0 & 575 & 100,0 \\
\hline
\end{tabular}

Nota: Foram excluídos 14 chefes de família, a respeito dos quais não se obteve informação.

Tabela 32- Distribuição das famílias dos quatro novos grupos sociais segundo referências a dívidas que não conseguem pagar. Santo André, SP, 2008.

\begin{tabular}{|c|c|c|c|c|c|c|c|c|c|c|}
\hline \multirow[b]{3}{*}{$\begin{array}{l}\text { Nome } \\
\text { no } \\
\text { Serasa } \\
\text { ou } \\
\text { dívidas }\end{array}$} & \multicolumn{8}{|c|}{ GRUPO SOCIAL } & & \\
\hline & \multicolumn{2}{|l|}{ I } & \multicolumn{2}{|c|}{ II } & \multicolumn{2}{|c|}{ III } & \multicolumn{2}{|c|}{ IV } & \multicolumn{2}{|c|}{ Total } \\
\hline & $\mathbf{N}$ & $\%$ & $\mathbf{N}$ & $\%$ & $\mathbf{N}$ & $\%$ & $\mathbf{N}$ & $\%$ & $\mathbf{N}$ & $\%$ \\
\hline Sim & 16 & 11,4 & 86 & 34,5 & 28 & 27,5 & 41 & 44,1 & 171 & 29,3 \\
\hline Não & 124 & 88,6 & 163 & 65,5 & 74 & 72,5 & 52 & 55,9 & 413 & 70,7 \\
\hline Total & 140 & 100,0 & 249 & 100,0 & 102 & 100,0 & 93 & 100,0 & 584 & 100,0 \\
\hline
\end{tabular}

Nota: Foram excluídos 5 chefes de família, a respeito dos quais não se obteve informação. 
Tabela 33- Distribuição das famílias dos quatro grupos novos sociais segundo gastos com crediários ou empréstimos. Santo André, SP, 2008.

\begin{tabular}{|c|c|c|c|c|c|c|c|c|c|c|}
\hline \multirow[b]{3}{*}{$\begin{array}{l}\text { Gastos com } \\
\text { crediários ou } \\
\text { empréstimos }\end{array}$} & \multicolumn{8}{|c|}{ GRUPO SOCIAL } & & \\
\hline & \multicolumn{2}{|c|}{ I } & \multicolumn{2}{|c|}{ II } & \multicolumn{2}{|c|}{ III } & \multicolumn{2}{|c|}{ IV } & \multicolumn{2}{|c|}{ Total } \\
\hline & $\mathbf{N}$ & $\%$ & $\mathbf{N}$ & $\%$ & $\mathbf{N}$ & $\%$ & $\mathbf{N}$ & $\%$ & $\mathbf{N}$ & $\%$ \\
\hline Sim & 59 & 41,8 & 109 & 43,8 & 39 & 38,6 & 56 & 59,6 & 263 & 45,0 \\
\hline Não & 82 & 58,2 & 140 & 56,2 & 62 & 61,4 & 38 & 40,4 & 322 & 55,0 \\
\hline Total & 141 & 100,0 & 249 & 100,0 & 101 & 100,0 & 94 & 100,0 & $585^{*}$ & 100,0 \\
\hline
\end{tabular}

Nota: Foram excluídos 4 chefes de família, a respeito dos quais não se obteve informação.

\section{5- Construção do Índice de Reprodução Social (IRS)}

Retomando-se o caminho percorrido, a definição das variáveis da dimensão da produção e do consumo passou por diversas etapas. O conjunto de variáveis testadas foi selecionado a partir de estudos prévios existentes e da observação da realidade social. Tal conjunto foi submetido à análise estatística multivariada análise fatorial - que norteou o corte do número de variáveis e resultou nos elementos que compuseram as dimensões de produção e de consumo já discutidas.

Tais variáveis sugeridas pela análise fatorial foram então submetidas à análise de agrupamentos via técnica Twostep (SPSS versão 17.0) com a finalidade de reclassificar as famílias dos jovens tendo por referência os chefes de família.

A partir dos quatro novos grupos gerados fez-se uso de outra técnica multivariada, a análise discriminante, que valida a análise de agrupamento (cluster) (Pestana e Gageiro, 2000). Na análise discriminante, por meio de combinações lineares de variáveis independentes que melhor discriminam os grupos (variável dependente qualitativa), são definidas as regras de classificação dos elementos em cada grupo. Tal análise busca assim o grau de concordância entre a classificação ideal e os grupos obtidos, gerando também funções de classificação (figura 1). Assim, identificou-se qual o grau de importância de cada uma das variáveis em comparação com o conjunto no que diz respeito à capacidade de diferenciar as famílias possibilitando sua classificação em um dos quatro grupos. 
No quadro 15 apresentam-se essas variáveis. As primeiras três apresentaram um alto grau de explicação do conjunto de dados $(77,6 \%)$, enquanto as duas variáveis seguintes e as quatro últimas apresentaram $16,3 \%$ e $6,1 \%$ respectivamente.

Quadro 15- Varáveis importantes para compor as dimensões da produção e do consumo. Santo André, SP, 2011.

\begin{tabular}{|l|r|r|r|}
\hline \multirow{2}{*}{} & \multicolumn{3}{|c|}{ Funções de classificação } \\
\cline { 2 - 4 } & \multicolumn{1}{|c|}{1} & \multicolumn{1}{c|}{2} & \multicolumn{1}{c|}{3} \\
\hline Acesso a serviços público: Esgoto & $0,659^{*}$ & $-0,047$ & $-0,070$ \\
Recebe conta de água? & $0,218^{*}$ & $-0,014$ & 0,040 \\
Recebe conta de Luz? & $0,213^{*}$ & $-0,003$ & $-0,036$ \\
Condição de Atividade e qualificação & 0,056 & $0,838^{*}$ & $-0,408$ \\
da ocupação & & & \\
Curso Preparatório & 0,048 & $0,470^{*}$ & 0,302 \\
Cômodos para dormir & 0,059 & 0,149 & $0,611^{*}$ \\
Propriedade da residência & $-0,020$ & 0,131 & $0,508^{*}$ \\
Paga IPTU? & 0,063 & 0,133 & $0,351^{*}$ \\
Atividade de Lazer: Cultos & $-0,038$ & $-0,002$ & $0,250^{*}$ \\
\hline
\end{tabular}

Nota:* Largest absolute correlation between each variable and any discriminant function. SPSS 17.0

Sendo assim, para cada família foi atribuído um valor para cada variável segundo o qualificador que caracterizava o chefe de família no caso da dimensão da produção ou o qualificador que caracterizava a família toda no caso da dimensão do consumo.

Ressalta-se que a condição de atividade e a qualificação da ocupação foram agregadas em uma única variável que também agregou indiretamente a escolaridade por ela estar relacionada à qualidade da ocupação, considerando que há correlação direta entre baixa escolaridade e baixa qualidade ocupacional (Pochmann, 1999). O registro em carteira também compôs essa variável pois a estabilidade no emprego interfere na caracterização da ocupação. Além disso, considera-se que o agrupamento dessas variáveis facilita a utilização do IRS.

Quanto às variáveis de consumo, no que diz respeito ao acesso a saneamento básico reduziram-se as variáveis para legalidade do acesso à água e luz (pagamentos de contas) e acesso a serviços públicos de esgoto. 
Destaca-se ainda que o conjunto de variáveis encontradas diferenciam-se do conjunto das utilizadas por Salum e Queiroz $(1997,2000,2010)$ para a construção dos grupos sociais homogêneos (renda familiar per capita, recebimento de benefícios oriundos do trabalho e registro em carteira para formas de trabalhar; e propriedade da habitação, exposição à riscos no local de moradia e agregação social para as formas de viver).

Os valores dos qualificadores para cada variável estão apresentados nos quadros 16 e 17. 
Quadro 16- Variáveis da dimensão da produção com os respectivos valores dos qualificadores. Santo André, SP, 2011.

\begin{tabular}{|c|c|}
\hline Variáveis da dimensão da produção com seus qualificadores & $\begin{array}{l}\text { Valores dos } \\
\text { qualificadores }\end{array}$ \\
\hline Curso preparatório para o trabalho & (A) \\
\hline Não & 0 \\
\hline Sim & 1 \\
\hline Condição de atividade e qualificação da ocupação & (B) \\
\hline Bico, desempregado em ocupação mal definida & 1 \\
\hline $\begin{array}{l}\text { Trabalhador familiar, autônomo ou assalariado sem carteira em } \\
\text { ocupação mal definida }\end{array}$ & 2 \\
\hline $\begin{array}{l}\text { Aposentado, pensionista, afastado do trabalho e empregador ou } \\
\text { assalariado com carteira em ocupação mal definida }\end{array}$ & 3 \\
\hline Bico, desempregado em ocupação do tipo não operacional/ apoio & 4 \\
\hline $\begin{array}{l}\text { Trabalhador familiar, autônomo ou assalariado sem carteira em } \\
\text { ocupação do tipo não operacional/ apoio }\end{array}$ & 5 \\
\hline $\begin{array}{l}\text { Aposentado, pensionista, afastado do trabalho e empregador ou } \\
\text { assalariado com carteira em ocupação do tipo não } \\
\text { operacional/apoio }\end{array}$ & 6 \\
\hline Bico, desempregado em ocupação de serviço de escritório & 7 \\
\hline $\begin{array}{l}\text { Trabalhador familiar, autônomo ou assalariado sem carteira em } \\
\text { ocupação de serviços de escritório }\end{array}$ & 8 \\
\hline $\begin{array}{l}\text { Aposentado, pensionista, afastado do trabalho e empregador ou } \\
\text { assalariado com carteira em ocupação de serviços de escritório }\end{array}$ & 9 \\
\hline Bico, desempregado em ocupação de serviços gerais & 10 \\
\hline $\begin{array}{l}\text { Trabalhador familiar, autônomo ou assalariado sem carteira em } \\
\text { ocupação de serviços gerais }\end{array}$ & 11 \\
\hline $\begin{array}{l}\text { Aposentado, pensionista, afastado do trabalho e empregador ou } \\
\text { assalariado com carteira em ocupação de serviços gerais }\end{array}$ & 12 \\
\hline Bico, desempregado em ocupação não qualificado na execução & 13 \\
\hline $\begin{array}{l}\text { Trabalhador familiar, autônomos ou assalariados sem carteira em } \\
\text { ocupação não qualificado na execução }\end{array}$ & 14 \\
\hline $\begin{array}{l}\text { Aposentado, pensionista, afastado do trabalho e empregador ou } \\
\text { assalariado com carteira em ocupação não qualificada na } \\
\text { execução }\end{array}$ & 15 \\
\hline Bico, desempregado em ocupação semi qualificada na execução & 16 \\
\hline $\begin{array}{l}\text { Trabalhador familiar, autônomo ou assalariado sem carteira em } \\
\text { ocupação semi qualificada na execução }\end{array}$ & 17 \\
\hline $\begin{array}{l}\text { Aposentado, pensionista, afastado do trabalho e empregador ou } \\
\text { assalariado com carteira em ocupação semi qualificada na } \\
\text { execução }\end{array}$ & 18 \\
\hline $\begin{array}{l}\text { Trabalhador familiar, autônomo ou assalariado sem carteira em } \\
\text { ocupação qualificada na execução }\end{array}$ & 19 \\
\hline $\begin{array}{l}\text { Aposentado, pensionista, afastado do trabalho e empregador ou } \\
\text { assalariado com carteira em ocupação qualificada na execução }\end{array}$ & 20 \\
\hline Planejamento e Organização & 21 \\
\hline Empresário, direção e gerência & 22 \\
\hline
\end{tabular}


Quadro 17- Variáveis da dimensão do consumo com os respectivos valores dos qualificadores. Santo André, SP, 2011

\begin{tabular}{|l|l|}
\hline Variáveis da dimensão do consumo com seus qualificadores & $\begin{array}{l}\text { Valores dos } \\
\text { qualificadores }\end{array}$ \\
\hline Propriedade da residência & $(\mathbf{C})$ \\
\hline Cedida, Outros & 0 \\
\hline Alugada & 1 \\
\hline Financiada & 2 \\
\hline Própria regular ou irregular & 3 \\
\hline Recebe conta de água? & $(\mathbf{D})$ \\
\hline Não & 0 \\
\hline Sim & 1 \\
\hline Recebe conta de Luz? & $(\mathbf{E})$ \\
\hline Não & 0 \\
\hline Sim & 1 \\
\hline Acesso a serviços público de esgoto & $(\mathbf{F})$ \\
\hline Não & 0 \\
\hline Sim & 1 \\
\hline Atividade de Lazer: Cultos & $(\mathbf{G})$ \\
\hline Não & 0 \\
\hline Sim & 1 \\
\hline Paga IPTU? & $(\mathbf{H})$ \\
\hline Não & 0 \\
\hline Sim & 1 \\
\hline Número de cômodos para dormir & $(\mathbf{I})$ \\
\hline Não tem & 0 \\
\hline 1 & 1 \\
\hline 2 & 2 \\
\hline 3 ou mais & 3 \\
\hline & \\
\hline
\end{tabular}

Em seguida, cada família foi submetida à multiplicação do peso de cada variável pelo valor do qualificador em cada um dos grupos segundo as equações abaixo (quadro 18). Os resultados obtidos (score) em cada um dos 4 grupos são comparados e classifica-se a família no grupo onde verifica-se o maior "score" (regra de classificação). 
Quadro 18- Equações para classificação das famílias nos quatro grupos sociais, 2011.

$\mathbf{G I}=-104,617+(6,403 x \mathrm{~A})+(0,924 \mathrm{xB})+(3,183 \mathrm{xC})+(32,688 \mathrm{xD})+(37,430 \mathrm{xE})+$ $(91,410 x F)+(4,267 x G)+(0,287 x H)+(4,588 x I)$

$\mathbf{G I I}=-91,779+(2,211 \mathrm{xA})+(0,707 x \mathrm{~B})+(2,315 \mathrm{xC})+(33,139 \mathrm{xD})+(39,367 \mathrm{xE})+$ $(89,323 \times \mathrm{F})+(2,911 \times \mathrm{xG})-(1,402 \times \mathrm{H})+(3,009 \mathrm{xI})$

GIII $=-92,493+(1,297 x A)-(0,030 x B)+(2,684 x C)+(35,192 x D)+(39,600 x E)+$ $(89,824 x F)+(3,359 x G)-(1,161 x H)+(4,109 x I)$

GIV $=-25,753+(2,160 x A)+(0,597 x B)+(2,323 x C)+(13,562 x D)+(20,201 x E)+$ $(32,427 x F)+(3,933 x G)-(0,785 x H)+(2,917 x I)$

Nota: Equações obtidas por meio do programa SPSS (versão 17.0) - Análise discriminante Classification Function Coefficients.

A tabela de concordância entre os grupos antes da análise e após encontra-se abaixo.

Tabela 34 - Comparação da distribuição das famílias entre os novos grupos gerados por clusters e os grupos gerados a partir da aplicação do IRS.

\begin{tabular}{llllll}
\hline \multirow{2}{*}{ Grupos } & \multicolumn{4}{c}{ Grupos submetidos ao IRS } & \multirow{2}{*}{ Total } \\
& I & II & III & IV & \\
\hline I & 110 & 31 & 2 & 0 & $\mathbf{1 4 3}$ \\
II & 16 & 228 & 6 & 0 & $\mathbf{2 5 0}$ \\
III & 2 & 6 & 96 & 0 & $\mathbf{1 0 2}$ \\
IV & 2 & 5 & 0 & 89 & $\mathbf{9 4}$ \\
Total & $\mathbf{1 2 6}$ & $\mathbf{2 7 0}$ & $\mathbf{9 9}$ & $\mathbf{8 9}$ & $\mathbf{5 8 9}$ \\
\hline
\end{tabular}

Nota:Percentual de concordância (classificação correta) $=88,8 \%$.

A distribuição, com um número menor de variáveis, que realmente discriminam o conjunto de dados obtidos, apontou um percentual de concordância em torno de $89 \%$, ou seja, 523 famílias em 589 dos casos foram corretamente classificadas.

A figura abaixo representa a distribuição das famílias nos grupos a partir da aplicação do IRS. 
Figura 1- Distribuição das famílias nos quatro grupos obtidos com a aplicação do IRS, 2011.

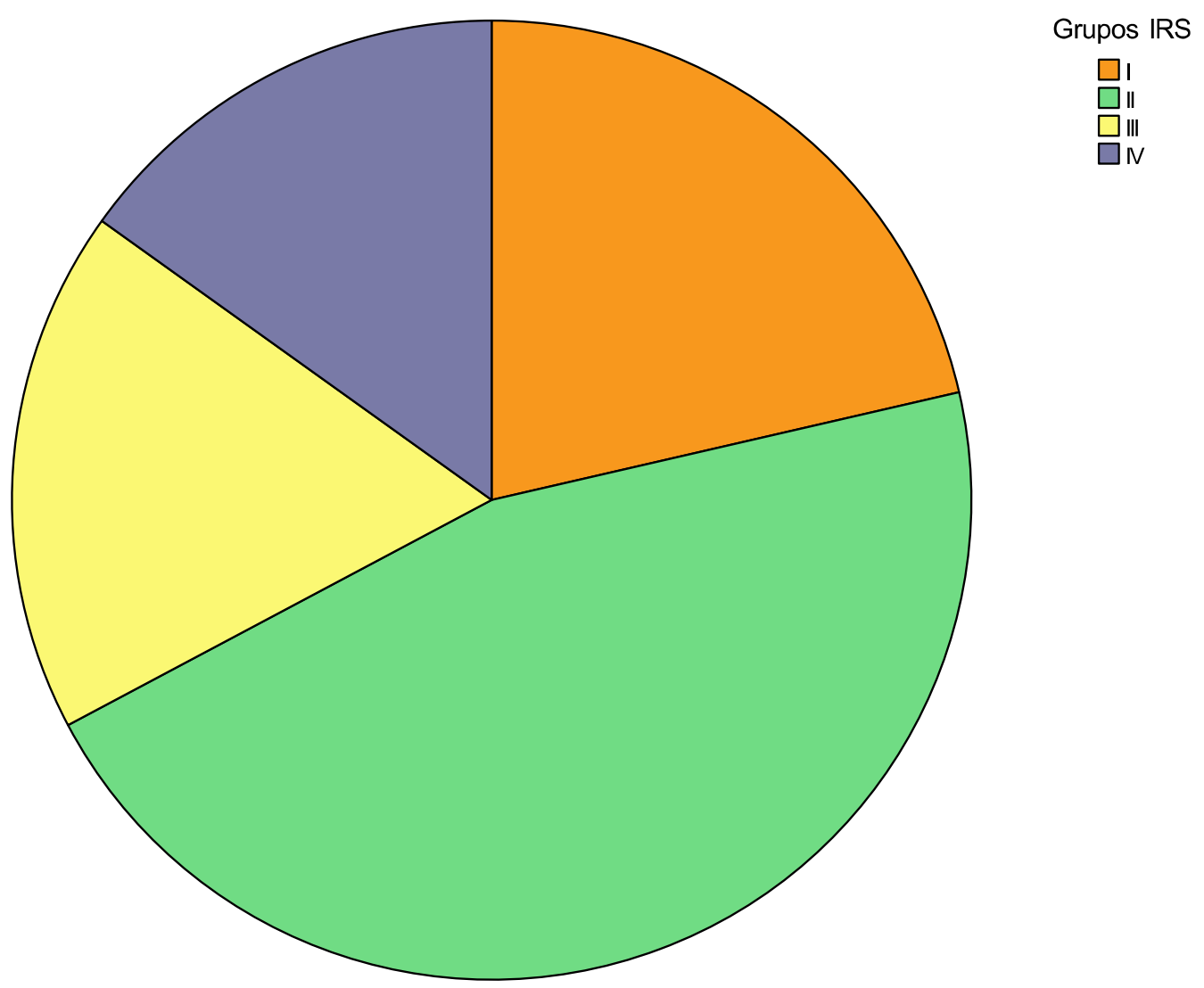

\section{6- Descrição dos quatro grupos sociais}

Grupo I (143 famílias)

A partir do que foi observado identifica-se que o grupo I apresenta maior estabilidade nas formas de trabalhar em comparação com os demais grupos. Apresenta principalmente chefes de família assalariados (72\%) e autônomos $(19,6 \%)$ não havendo nenhum desempregado e nenhum chefe fazendo bicos (tabela 10). 
Quanto à qualificação para o trabalho, quase metade dos chefes ocupa cargos de planejamento, organização, gerência e direção (tabela 11). Mais de $75 \%$ dos chefes fez algum curso preparatório para o trabalho (tabela 13).

Esse grupo também apresenta maior estabilidade nas formas de viver. A quase totalidade $(95,1 \%$ ) tem casa própria (tabela 20$)$ e todos pagam IPTU (tabela 21), ou seja, não possuem imóveis de valor muito baixo ou condições de exposição a riscos como enchentes que os isentaria do imposto. Mais de $70 \%$ das moradias dessas famílias tem mais de três cômodos para dormir (quadro 9) e todas as famílias desse grupo tinham acesso à água, luz, esgoto e esse acesso era legalizado (tabelas 23, 24, 25, 26, 28 e 29). Mais da metade referiu o culto à igreja (de qualquer religião) como forma de lazer (quadro 11).

\section{Grupo II (250 famílias)}

As famílias desse grupo não apresentam a mesma estabilidade das formas de trabalhar e de viver das famílias do grupo I. Mais de $40 \%$ trabalha em atividades semi qualificadas na ocupação (tabela 11) e menos de um quarto (22\%) realizou algum curso preparatório para o trabalho (tabela 13). Quanto à condição de atividade se assemelham ao grupo I com $74 \%$ de assalariados e cerca de $18 \%$ de autônomos (tabela 10).

Quanto às formas de viver, verificou-se que mais de um terço das famílias vivia em casas alugadas (tabela 20) e quase a mesma porcentagem não pagava IPTU (tabela 21). Mais de $80 \%$ morava em casas com até dois cômodos para dormir (quadro 9). Todas as famílias tinham acesso à água, luz e esgoto (tabelas 23, 24, 25), mas $2,4 \%$ não pagavam conta de água (tabela 28). Menos da metade referiu a freqüência a cultos como forma de lazer (quadro 11).

\section{Grupo III (102 famílias)}

Esse grupo apresenta a especificidade de ter grande parte de suas famílias afastada do mercado de trabalho, quase $70 \%$ são pensionistas, desempregados ou afastados pelo INSS para os quais as variáveis de qualificação da ocupação e curso preparatório para o trabalho não se aplica (tabela 10).

Quanto às formas de viver, mais de $75 \%$ das famílias possui casa própria (tabela 20) e quase $80 \%$ paga IPTU (tabela 21). Mais de $90 \%$ das famílias mora em 
casas com dois cômodos (quadro 9). Quanto ao acesso à água, luz e esgoto, verificou-se que $1 \%$ das famílias não tinha acesso à luz (tabela 24 ) e não pagava a conta desse serviço (tabela 29). Quase $70 \%$ das famílias freqüentava igrejas como forma de lazer (quadro 11).

\section{Grupo IV (94 famílias)}

O grupo IV apresenta de forma geral maior instabilidade no trabalho e na vida se comparado com o grupo I e II. Apresenta menos assalariados que o grupo I e II $(60,6 \%)$ (tabela 10). Cerca de um terço dos chefes trabalha em ocupações semiqualificadas na execução (tabela 11) e um quarto realizou curso preparatório para o trabalho (tabela 13).

Quanto às formas de viver observou-se que quase $80 \%$ das famílias desse grupo possui casa própria (tabela 20), mas cerca de $40 \%$ não paga IPTU (tabela 21) o que caracteriza moradias com pouca infraestrutura. Cerca de um quarto dessas famílias tem apenas um cômodo no domicílio para dormir (quadro 9). Quanto ao acesso a serviços de saneamento básico e acesso à luz, identificou-se que 18,1\% não tinha acesso à água encanada (tabela 23), 10,6\% não tinha acesso à luz (tabela 24) e $80,9 \%$ não tinha acesso à esgoto encanado (tabela 25), ressaltando-se que essas famílias viviam em região de mananciais. Quanto legalidade do acesso, verificou-se que $38,3 \%$ não pagava conta de água (tabela 28) e 31,9\% não pagava a de luz (tabela 29). Esse grupo apresenta a maior frequiência aos cultos como forma de lazer $(71,3 \%)$ (quadro 11).

\section{7- Possibilidades de aplicação do IRS}

A partir das variáveis da dimensão da produção e do consumo definidas foi possível elaborar um formulário para ser aplicado com a finalidade de classificar as famílias em um dos quatro grupos sociais (Anexo VII).

Por meio desse instrumento é possível identificar os perfis de reprodução das famílias que, em conjunto com os perfis de saúde-doença, conformam os perfis epidemiológicos. Nessa perspectiva os serviços de saúde podem mapear os quatro 
grupos sociais em seu território de abrangência e planejar intervenções voltadas para as necessidades de saúde dos diferentes grupos.

O formulário pode ser aplicado no momento de cadastro das famílias na unidade de saúde, no momento do atendimento no serviço ou ainda durante as visitas domiciliares dos agentes comunitários de saúde da Estratégia de Saúde da Família, que se constitui na estratégia de reorientação do modelo assistencial e de operacionalização da política atual de saúde no Brasil (Ministério da Saúde, 2011). Parte das informações pode ser obtida também a partir de prontuários.

Propõe-se a construção de bancos de dados alimentados com as informações do formulário sendo que a classificação das famílias pode ser realizada por meio da utilização de programas como o SPSS (versão 17.0). Entretanto, nos locais em que o acesso à tecnologia é difícil a classificação pode ser feita a partir de cálculos utilizando-se as fórmulas das equações.

Espera-se que as informações do formulário e a classificação das famílias possa futuramente compor o Sistema de Informação em Atenção Básica (SIAB) de forma a possibilitar o mapeamento dos grupos sociais em dado território com apoio de técnicas de geoprocessamento, embasando tanto o planejamento no âmbito do serviço de saúde, quanto o planejamento de políticas públicas voltadas para os determinantes sociais do processo saúde-doença. 
8. Análise e Discussão 


\section{8 - Análise e Discussão}

\section{1- Distribuição dos grupos nos bairros estudados}

Verificou-se que em cada bairro havia famílias de mais de um grupo social. Assim, as variáveis de reprodução social utilizadas para compor o IRS captam a heterogeneidade geossocial, resultado menos evidente quando utiliza-se os censos nacionais.

Outros estudos buscam superar o obstáculo de se identificar as heterogeneidades sociais do território. A proposta classificatória de Akerman (1997)

- Construção de Indicadores Compostos - define as áreas homogêneas do território por meio da articulação de variáveis socioeconômicas e de meio ambiente e tem o mérito de trabalhar com a análise macro estrutural do território - na tentativa de superar a insuficiência de propostas para avaliar diferenciais intra-urbanos e com um conjunto de indicadores hierarquizados. Entretanto, ao valer-se de dados estatísticos setoriais, homogeneíza o retrato de cada um dos setores censitários conferindo o estatuto de microáreas homogêneas, não discriminando as desigualdades sociais. A utilização das variáveis de trabalho e vida, por sua vez, demonstrou que existe uma miscigenação da riqueza nos bairros das famílias entrevistadas, ou seja, os bairros possuem uma heterogeneidade que estava mascarada pelas médias. Dessa forma fica clara a diversidade dos microespaços cujas especificidades de reprodução social são objeto da Epidemiologia Crítica. A realidade captada no microespaço é muito diferente da fotografia macro obtida com a aplicação de outros índices que utilizam médias como o IDH, por exemplo.

\section{2- Dimensão da produção}

A questão do trabalho apresenta-se essencial na discussão a respeito da diferenciação de grupos sociais. Uma prova disso diz respeito à variável condição de atividade, que mostrou-se importante elemento definidor a ponto de ser responsável pela constituição de um grupo particular, grupo III, composto por chefes de família que não estavam inseridos ativamente no mercado de trabalho como aposentados, 
pensionistas e desempregados. Assim, dos quatro grupos obtidos, três foram formados a partir de diferentes formas de trabalhar e de viver: o grupo I (plenamente incluído no trabalho e na vida), o grupo II (parcialmente incluído no trabalho e na vida) e o grupo IV (precariamente incluído no trabalho e na vida). Já grupo III é basicamente composto por chefes de família que encontram-se fora do mercado de trabalho, com condições de vida ora melhores, ora piores que o grupo II. Nessa perspectiva, a condição de atividade em conjunto com a qualificação da ocupação não poderia deixar de compor a dimensão da produção do IRS.

Segundo a leitura de Viana (2009) sobre a obra de Marx, é o processo de produção e reprodução da vida material que determina o conjunto das relações sociais. Esse processo de produção é definido por uma determinada forma de organização do trabalho, que portanto é o aspecto determinante das demais relações sociais. Estas, porém, possuem uma autonomia relativa, e, por sua vez influenciam a organização do trabalho. Nas sociedades divididas em classes sociais, a organização do trabalho se manifesta como organização marcada pelo conflito e o conteúdo da organização do trabalho é caracterizado pelas relações instauradas entre as classes sociais envolvidas nos processos (Viana, 2009).

Verificou-se que as varáveis da dimensão da produção obtidas nesse estudo (condição de atividade e qualificação do trabalho, curso preparatório para o trabalho) configuram-se em variáveis clássicas que continuam apresentando papel central na explicação da diferenciação entre grupos sociais, o que reforça a potencialidade da teoria marxista para explicar a realidade social.

Wright, sociólogo americano defensor da potencialidade da teoria marxista em gerar proposições sobre o mundo material, afirma que sua principal premissa se fundamenta na distinção entre o nível da aparência e a realidade social que produz essa aparência. O autor afirma que uma teoria capaz de explicar a realidade deve, primeiramente, ser formulada a partir de um caminho claro que demonstre as relações de causa entre as categorias estruturais e o nível das aparências captadas em uma investigação (Wright, 1989).

O autor atualiza a discussão das relações de exploração entre as classes sociais no modo de produção capitalista contemporâneo e sua construção teórica embasa a discussão do presente trabalho que lida com grupos sociais com diferentes 
inserções no processo de reprodução social tomados como forma de operacionalizar o conceito de classe social.

Wright afirma que o conceito de estrutura de classes não é o único que embasa a análise de classe. Outros elementos conceituais incluem a formação de classe (formação de classe em uma coletividade socialmente organizada com atores sociais), luta de classes (prática de atores para a realização de interesses de classes), e consciência de classe (compreensão de seus atores a respeito dos interesses de classes). A tarefa da análise de classes não é simplesmente compreender a estrutura de classes e seus efeitos, mas compreender as interconexões entre todos esses elementos e suas consequiências para outros aspectos da vida social. Entretanto, o autor ressalta que a estrutura de classe conceitualmente permanece como base para explicar toda a lógica de análise de classes porque ao se falar de formação de classe, luta de classe e consciência de classe deve-se ter claro de que estrutura de classes está se falando. (Wright, 1997).

A base da estrutura de classes no capitalismo coloca-se a partir da relação entre explorador e explorado e está diretamente relacionada ao grau de autonomia que os sujeitos têm sobre seu trabalho, o que por sua vez relaciona-se à sua posição na estrutura hierárquica diretamente ligada à qualificação do trabalho. Essa variável já foi destacada por Salum e Queiroz (1997, 2000, 2010) como uma das variáveis principais para classificar a estabilidade das formas de trabalhar das famílias e relaciona-se diretamente com a escolaridade e com a realização de cursos preparatórios para o trabalho que também compôs o IRS construído no presente estudo.

Dentro da tradição marxista de análise de classes, as divisões de classe são definidas principalmente em termos da ligação entre relações de propriedade e exploração. Na sociedade capitalista, a principal forma de exploração está centrada nos direitos sobre a propriedade e os meios de produção. Os direitos de propriedade geram três classes principais: capitalistas (exploradores) que possuem os meios de produção e empregam trabalhadores, trabalhadores (explorados) que não possuem os meios de produção e vendem sua força de trabalho para os capitalistas e a pequena burguesia (nem exploradores, nem explorados) que se apropriam e usam os meios de produção sem empregar outros (Wright, 1997). 
Há um número grande de razões para relacionar o conceito de classe à exploração, no lugar de simplesmente considerar oportunidades de vida baseadas no mercado como ocorre com o referencial weberiano (a quantidade de recursos que o indivíduo possui, afeta suas oportunidades nas trocas de mercadoria). Usando o exemplo dos gerentes, suas posições de classe não são determinadas somente por sua posição no mercado de força de trabalho gerencial, mas também por sua posição de dominação nas relações de produção. $\mathrm{O}$ conceito de classe baseado na exploração aponta para o fato de que as relações de classe são relações de poder, não meramente privilégio (Wright, 1997).

Teorizar por meio da exploração deixa mais claro a análise dos conflitos sociais. Explicações de conflitos requerem ao menos dois elementos: um relacionado aos interesses em jogo no conflito e outro ligado à capacidade dos atores em lutar por seus interesses. A simples oposição de interesses não é suficiente para explicar os conflitos entre grupos. Exploradores não têm somente um interesse em limitar as oportunidades de vida dos explorados, eles também dependem do explorado para a realização dos seus próprios interesses. A compreensão do poder inerente das classes exploradas é marginalizada quando a classe é definida estritamente por meio de relações de mercado. Deve-se destacar ainda que as relações de exploração são instáveis e interdependentes: o explorador necessita do explorado, e a exploração precisa ser mantida estável por meio de instituições políticas e práticas ideológicas. (Wright, 1997)

Wright reforça que não existem apenas as relações de exploração baseadas na posse dos meios de produção, mas também relações de dominação voltadas ao controle do conhecimento e posse de especializações que compõe uma classe de especialistas que conformam as posições das classes médias na estrutura de classe. Além disso, estar em uma posição de classe significa que o indivíduo faz certas coisas e certas coisas acontecem a ele (experiências vividas), lembrando que o sujeito recorre a alternativas estratégicas para atingir o seu bem-estar. Ressalta-se, entretanto, que ocupações dentro das relações de produção correspondem a caminhos possíveis que ligam os indivíduos a esses interesses e experiências, mas não são o único caminho. A família, por exemplo, promove outros tipos de relações sociais que ligam pessoas a estruturas de classe, considerando inclusive a relação entre classe e gênero (Wright, 1997). 
Destaca-se ainda que as relações de classe da sociedade capitalista se dão em termos de três processo relacionados às relações sociais de produção: controle da força de trabalho, controle dos meios físicos de produção e controle dos investimentos e recursos. As forças de classe centrais dentro do processo capitalista de produção - burguesia e proletariado- pode então ser compreendida como representando as posições polares de classe dentro de cada um desses três processos. Existem ainda três posições contraditórias dentro desse conjunto: gerentes e supervisores ocupam uma posição contraditória entre a burguesia e o proletariado, pequenos empregadores ocupam uma posição entre burguesia e pequena burguesia e empregadores semi-autônomos ocupam uma posição contraditória entre a pequena burguesia e o proletariado (Wright, 1978).

$\mathrm{Na}$ divisão de classes não se pode negar a presença da classe média principalmente porque a questão que se coloca é: como diferenciar posições de classe entre classes que não são proprietárias dos meios de produção? Wright divide assim a classe dos empregados a partir de dois elementos: a relação de autoridade dessas classes dentro do processo de produção e a posse de qualificação ou especialização para o trabalho (Wright, 1997), o que nos remete novamente para a variável de qualificação para o trabalho utilizada no presente estudo no processo de diferenciação dos quatro grupos sociais.

No que diz respeito à relação de autoridade ressalta-se que os capitalistas não somente são proprietários dos meios de produção e /ou contratam trabalhadores, eles dominam os trabalhadores por dentro do processo de produção. Nesses termos os gerentes e supervisores possuem uma localização contraditória dentro das relações de classe já que eles ao mesmo tempo pertencem à classe do capitalista e dos trabalhadores porque eles controlam os trabalhadores, mas ao mesmo tempo são empregados pelos capitalistas e explorados por eles. Por outro lado gerentes e supervisores ocupam uma posição privilegiada em relação aos outros trabalhadores por serem menos explorados e se apropriarem de certa forma melhor do excedente social por ter melhores salários (Wright, 1997). Dessa forma, Wright elaborou um esquema que representa as posições de classe ressaltando-se que tratam-se de posições dentro das relações de classe mas não propriamente as classes em si .

Quanto à especialização/qualificação, assim como os supervisores e gerentes, os empregados que possuem altos graus de especialização apresentam posição 
privilegiada dentro das relações de produção. Esses empregados são mais difíceis de serem supervisionados, pois isso exige uma especialização maior ainda e, além disso, esses empregados são mais hábeis em se apropriar dos excedentes do fruto do trabalho devido à posição que ocupam dentro das relações de poder.

Em síntese, o modo de produção capitalista se pauta nas relações de exploração entre as classes sociais. Tais relações são determinadas pelas relações de autoridade dentro do processo que estão ligadas tanto à qualificação do trabalho e à posição hierárquica (gerentes, supervisores, executores), quanto à qualificação/especialização para o trabalho relacionada à escolaridade e à realização de cursos preparatórios.

Assim, dos quatro grupos sociais estudados no presente trabalho, o Grupo I mais incluído socialmente - apresenta principalmente chefes de família qualificados na execução e inseridos em atividades de planejamento, organização, direção e gerência. A grande parte realizou algum curso preparatório para o trabalho. O Grupo II - parcialmente inserido - concentrava trabalhadores em atividades semiqualificadas na execução, sendo que menos de um quarto fizeram curso preparatório para o trabalho. O grupo IV - mais excluído - é formado principalmente por chefes de família semi-qualificados na execução, mas concentra um número maior de qualificações mal-definidas em comparação aos outros dois grupos. Nesse grupo um quarto realizou cursos preparatórios para o trabalho. Ressalta-se que grande parte dos chefes de família do Grupo III não estavam inseridos no mundo do trabalho sendo em sua grande maioria aposentados, pensionistas e afastados pelo INSS.

A discussão sobre um grupo social composto por chefes de família não incluídos diretamente no mundo do trabalho não se conduz facilmente. Segundo Wright para realizar a análise desse grupo composto por pensionistas, donas de casa, estudantes, que não são diretamente definidas pelas relações sociais de produção, torna-se necessário introduzir outra distinção na discussão, a distinção entre interesses de classe fundamentais e imediatas (Wright, 1978).

Nem todos os objetivos potenciais dos atores de classes podem ser considerados interesses. Interesses de classe na sociedade capitalista são aqueles objetivos potenciais que se tornam objetivos reais de lutas na ausência das mistificações e distorções das relações capitalistas. Os interesses de classe imediatos constituem interesses dentro de uma dada estrutura de relações sociais e os interesses 
fundamentais centram-se em interesses os quais descrevem as questões de estrutura das próprias relações sociais. Isto é, interesses imediatos são interesses definidos dentro de um dado modo de produção (interesses que tomam o modo de produção como dado), enquanto interesses fundamentais são definidos entre modos de produção (eles descrevem questões do próprio modo de produção). Os interesses imediatos econômicos da classe trabalhadora, por exemplo, são definidos largamente pelas relações de mercado. Lutas por melhores salários, melhores condições de vida, por melhorias na educação, todos constituem lutas por objetivos definidos dentro da estrutura básica do capitalismo. Lutas pelo socialismo, por outro lado, mudam a premissa das relações capitalistas e refletem interesses fundamentais da classe trabalhadora. (Wright, 1978)

Ressalta-se que interesses imediatos não são interesses falsos, são interesses incompletos. As lutas por melhores salários refletem uma compreensão correta dos trabalhadores a respeito de suas condições imediatas de existência dentro do capitalismo; entretanto, a restrição das lutas apenas à questão dos salários reflete uma compreensão incompleta da natureza da sociedade capitalista como tal e dificulta o processo de transcendência do sistema de exploração capitalista para o socialismo. Os interesses fundamentais e imediatos estão dialeticamente ligados. Como os interesses imediatos estão fortemente presentes no dia a dia seria utópico considerar que a classe trabalhadora vai ser organizar em torno dos interesses fundamentais. Diferentes classes têm diferentes interesses imediatos e os interesses imediatos e fundamentais apenas coincidem em momentos revolucionários (Wright, 1978)

Assim é possível a aproximação a respeito da localização de classe de cada posição para um número específico de categorias que estão fora das relações de produção tais como as que no presente estudo compuseram o grupo III (Wright, 1978):

- Donas de casa: a produção doméstica deve ser tratada como a fase final da produção capitalista e dificilmente a esposa de um trabalhador teria interesses fundamentais diferentes da classe trabalhadora. Ressalta-se que a divisão sexual do trabalho não cria a divisão de interesses de classe fundamentais entre maridos e suas esposas. (Wright, 1978)

- Pensionistas: pode-se considerar a classe social segundo a trajetória de classe da posição no qual estava ligado. 
- Desempregados: consistem em problema para a análise de classe. No que diz respeito aos temporariamente desempregados pode-se considerar a trajetória de classes. Mas isso não se aplica aos definitivamente desempregados. Em termos marxistas eles poderiam ser classificados como lupemproletariado, entretanto isso não é satisfatório pois poderia sugerir que eles têm interesses fundamentalmente opostos aos da classe trabalhadora. No nível dos interesses imediatos há um abismo entre os permanentemente desempregados e a classe trabalhadora, já que a classe trabalhadora paga impostos utilizados para subsidiar a população desempregada. Em relação aos interesses fundamentais a questão é mais ambígua. Enquanto o desemprego permanente pode gerar uma "anticonsciência" capitalista, isso não garante que se gere uma consciência socialista. Sendo assim, Wright considera o desempregado permanente um segmento marginalizado da classe trabalhadora (Wright, 1978).

Segundo Viana (2009), lupemproletariado é equivalente ao conceito marxista de exército industrial de reserva, formados por aqueles que possuem necessidade de vender sua força de trabalho e que estão fora do mercado e assim estão marginalizados também no mercado de consumo. Segundo o autor, existem graus diferenciados de marginalização no mercado de trabalho, no mercado de consumo e na cidadania. Alguns vivem em subemprego, outros estão completamente excluídos do mercado de trabalho e há aqueles que se empregam temporariamente. Alguns conseguem consumir os meios necessários para a sobrevivência e outros nem isso; alguns usufruem alguns direitos sociais e outros encontram-se totalmente excluídos.

Assim, é importante ressaltar que os conceitos de lumpreproletarização e lupemproletariado estão inseridos em uma teoria de classes sociais, como apresentou Wright. Por isso Viana (2009) aponta que o lupemproletariado não está totalmente excluído pois os indivíduos lupemproletários podem, momentaneamente, estar fora do mercado de trabalho, longe do acesso aos direitos sociais (da cidadania) e marginalizados no mercado de consumo, mas não definitivamente. Ocorrem mudanças sociais que alteram essa situação, além de existir uma mobilidade entre lupemproletariado e proletariado, entre segmentos do lupemproletariado etc.

Viana (2009) afirma que na atualidade, o desemprego em massa volta a atingir os países capitalistas imperialistas, provocando um novo processo de lupemproletarização. Isso ocorre devido às novas dificuldades do processo de 
acumulação capitalista, iniciado na década de 60 (momento de ascensão das lutas operárias e estudantis) e início da década de 70, que foram reprimidas até a década de 80 , quando se iniciou o processo de supremacia do neoliberalismo enquanto nova resposta do capital ao contexto mundial. No processo de extração de mais-valor, a chamada reestruturação produtiva (toyotismo e similares) veio tentar reverter a tendência declinante da taxa de lucro, utilizando simultaneamente novas tecnologias e métodos organizativos, visando extrair um maior quantum de mais-valor. Além disso, a política neoliberal com o processo de desregulamentação tem por objetivo principal diminuir despesas do capital e aumentar o processo de exploração. Também o processo de precarização, terceirização, subcontratação, "trabalho autônomo", reforçam a exploração.

Segundo Pochmann (1999), pode-se observar dois períodos muito distintos no que diz respeito à evolução do mercado de trabalho. Um movimento de estruturação do mercado de trabalho que ocorreu simultaneamente ao processo de industrialização e institucionalização das relações e condições de trabalho (1940/80), marcado pela expansão do emprego assalariado, principalmente com registro, e das ocupações nos segmentos organizados da economia (tipicamente capitalistas). O período pós 1980 foi de reversão na trajetória geral das ocupações acompanhado de uma progressiva desestruturação do mercado de trabalho. $\mathrm{O}$ autor aponta, entretanto, que o mercado de trabalho apresenta uma evolução dependente do desenvolvimento da economia e que as razões das diferentes dinâmicas do seu funcionamento não devem ser buscadas tão somente nas variáveis endógenas do mercado de trabalho. É preciso ir além, procurando entender como as mudanças no padrão de desenvolvimento, no modo de inserção internacional e nas políticas macroeconômicas afetam o nível e a composição ocupacional, os rendimentos e mesmo as novas formas de contratação e uso da força de trabalho.

A supremacia mundial do neoliberalismo, a informatização, as tentativas de reestruturação produtiva e a exploração imperialista criam um processo de lupemproletarização que se soma ao que já existia anteriormente (Viana, 2009). Nesse contexto, marcado por um novo regime de acumulação, que volta a crescer o desemprego. A reestruturação produtiva buscar aumentar não somente a extração do mais-valor relativo (produtividade), mas também mais valor absoluto, no qual se utiliza também, de forma complementar, o que Marx denominou "métodos 
secundários de exploração capitalista", tal como se vê em certas formas de trabalho autônomo. Isso é complementado pelo retorno do uso em massa da força de trabalho precoce (crianças e jovens) que também provoca o desemprego de trabalhadores adultos, pois é mais vantajoso para o capital explorar crianças, já que a taxa de exploração é maior. Nesse contexto, a lupemproletarização - aumento do exército de reserva - também está incluída nesse processo e tem o efeito de aumentar a competição pelo mercado de trabalho e fazer crescer fenômenos como xenofobia, miséria, violência, e, o que é do interesse do capital, pressionar os salários para baixo. É nesse contexto que surge a ideologia da exclusão social e as políticas paliativas (renda cidadã, bolsa-escola etc), que vêm substituir as políticas sociais clássicas de estado integracionista, dito do "bem estar social" (Viana, 2009).

$\mathrm{O}$ processo de lupemproletarização atinge o mundo inteiro já que "a globalização do desemprego"e do "trabalho temporário" afeta até mesmo o país capitalista mais desenvolvido (Mészáros, 2006). Entretanto, a política neoliberal no Brasil assume um caráter muito mais cruel para a população brasileira pois não é marcado pelo protecionismo como ocorre nos países imperialistas. Cita-se aqui o exemplo das fábricas de calçados em São Paulo que estão indo à falência por causa dos calçados que vêm da China. O neoliberalismo brasileiro abre as portas para o capital estrangeiro e seus produtos destruindo parte do capital nacional e gerando desemprego. Isso é mais grave ainda quando nota-se que as políticas estatais e os gastos do governo brasileiro com a resolução dos problemas sociais continuam sendo escassos, comparando-se com os realizados pelos países imperialistas, embora alguns programas assistencialistas venham sendo implantados (bolsa-escola, renda cidadã, etc) (Viana, 2009).

Segundo Pochmann (2006), o Brasil vive atualmente, a mais grave crise do emprego da sua história mesmo comparando-se com o período da transição do trabalho escravo para o assalariamento, ao final do século XIX, com a depressão econômica de 1929 e com as graves recessões nas atividades produtivas nos períodos 1981- 1983 e 1990-1992 . São os componentes da desestruturação do mercado de trabalho: a) presença em grande escala do desemprego em praticamente todos os segmentos sociais; b) destruição de postos de trabalho de maior qualidade sem a mesma contrapartida nos empregos criados. 
O desemprego vem aumentando continuamente no Brasil desde 1990 constatando-se alterações substanciais na composição do conjunto de trabalhadores que não têm emprego, considerando que há variações de entre as classes no que diz respeito a rendimento familiar, gênero e raça. A partir dos anos 1990, a taxa média de desemprego aberto cresceu de maneira considerável. Entre 1992 e 2002 o desemprego passou de 6,7\% para 9,3\% do total da população economicamente ativa o que significa um aumento relativo próximo a $40 \%$. Nas famílias de classe baixa, a taxa de desemprego subiu de $9,4 \%$ para $13,8 \%$, portanto, com um crescimento relativo de $46,8 \%$. Por outro lado, a taxa de desemprego da classe média alta passou de $2,6 \%$ para $3,9 \%$, com uma variação de $50 \%$. Soma-se a isso o fato de que em 2002 a abertura de novos postos de ocupação em comparação a 1992 foi muito menor na camada de renda baixa. Nessa camada, a geração de empregos havia crescido apenas $15,8 \%$ nesse período de dez anos enquanto a média nacional aumentou 20,2\% no mesmo período de tempo (Pochmann, 2006).

$\mathrm{Na}$ distribuição do desemprego por gênero, associada ao critério de rendimento familiar percapita, outras importantes disparidades podem ser observadas. O desemprego masculino, por exemplo, aumentou mais rapidamente, para a classe média alta (65\%). Já para a classe de renda baixa o desemprego cresceu bem menos (34\%). No caso das mulheres o quadro é inverso. A taxa de desemprego feminino elevou-se mais $(59,3 \%)$ para as famílias com rendimento baixo. Para as mulheres na faixa de maior rendimento, a taxa aumentou $42,4 \%$ nesse período (Pochmann, 2006).

No que diz respeito à relação entre desemprego e raça pode-se observar que a discriminação racial alcançou novas formas de manifestação, ainda mais sofisticadas. A taxa de desemprego dos negros pobres cresceu menos, uma vez que esses tenderam a estar associados, em geral, à ocupações mais precárias, enquanto o desemprego dos negros de média e alta renda explodiu, provavelmente porque, em uma escassez de empregos especializados, o preconceito racial esteve presente na decisão da não contratação. Assim a discriminação racial passou a excluir de ocupações mais nobres aqueles, que, depois de muito esforço, haviam alcançado maior renda e escolaridade (Pochmann, 2006).

O emprego apresenta-se assim como questão central na definição da exclusão social já que ele pode ser destacado como uma das principais condições de acesso à 
renda e aos serviços sociais. Os pressupostos neoliberais levaram ainda à busca de maior flexibilidade no uso e remuneração de mão de obra, identificada como mecanismo necessário ao aumento de empregos sendo que a qualidade das ocupações geradas pouco importa (Pochmann (1999).

A flexibilização tem sido apontada pelos teóricos neoliberais como uma das alternativas para se combater o desemprego e que na verdade se apresenta como: a) liberdade da empresa para despedir parte dos seus empregados, sem penalidades, quando o lucro diminui; b) liberdade da empresa para reduzir ou aumentar o horário de trabalho sem aviso prévio, quando a produção necessite; c) abertura para que a empresa pague salários mais baixos do que a paridade de trabalho, seja para solucionar negociações salariais ou poder participar de uma concorrência internacional; d) possibilidade de a empresa subdividir a jornada de trabalho em dia de semana de sua conveniência, mudando os horários e as características (trabalho por turno, por escala, em tempo parcial); e) Liberdade para destinar parte de sua atividade a empresas externas; d) possibilidade de contratar trabalhadores em regime de trabalho temporário, de fazer contratos por tempo parcial diminuindo o pessoal efetivo a índices inferiores a 20\% do total da empresa (Vasapollo, 2006).

Ressalta-se ainda que a flexibilização do trabalho ganhou maior impulso com a desaceleração no ritmo da expansão do emprego assalariado regular após o final dos anos 70 no Brasil. O crescimento de ocupações assalariadas sem registro formal e não-assalariadas, em pequenas empresas, deu maior amplitude aos segmentos econômicos pouco organizados e à precarização do mercado do trabalho (Pochmann, 1999). Assim, a flexibilização não é solução para aumentar os índices de ocupação. É uma imposição à força de trabalho para que sejam aceitos salários reais mais baixos e piores condições. Com a mundialização econômico produtiva, o trabalho ilegal vem se acentuando porque os países industrializados deslocam sua produção para além dos limites nacionais e investem em países nos quais as garantias trabalhistas são mínimas e é alta a especialização do trabalho, conseguindo assim, custos fundamentalmente mais baixos e aumentando a competitividade (Vasapollo, 2006).

Nessa perspectiva, a informatização produzia e produz mutação no mercado de trabalho, pois em plena era da informatização vive-se a era da informalização do trabalho, caracterizada pela ampliação dos terceirizados, pela expansão dos assalariados do Call Center, subcontratados, flexibilizados, trabalhadores em tempo 
parcial, ou seja, pelo ciberproletariado que trabalha com a informática e vivencia uma realidade moldada pela vivência da precarização. (Antunes, 2006).

Assiste-se assim, à configuração de uma sociedade cada vez mais desigual, conformada por aqueles que se encontram plenamente incluídos, por meio de uma ocupação regular e de boa qualidade; pelos precariamente incluídos (subempregos, ocupações atípicas, parciais); e os excluídos (sem emprego por longa duração) (Pochmann, 1999).

Ressalta-se que essa realidade desigual não resultou em redução do dinamismo econômico graças à constituição de uma nova classe social denominada por Souza (2010), de "nova classe trabalhadora brasileira" que se situa entre as classes completamente excluídas ("ralé") e as classes média e alta. Essa classe foi responsável por fortalecer o mercado interno na última década. Está incluída no sistema econômico como produtora de bens e serviços e como consumidora, mas é tão esquecida e estigmatizada quanto a "ralé". Ao mesmo tempo, conseguiu, “ internalizar e incorporar disposições de crer e de agir que lhe garantiram um novo lugar na dimensão produtiva (...)" (Souza, 2010. p. 48) a custa de um grande esforço e à:

“(...) sua capacidade de resistir ao cansaço de vários empregos e turnos de trabalho, à dupla jornada na escola e no trabalho, à extraordinária capacidade de poupança e de resistência ao consumo imediato (...) e a uma extraordinária crença em si mesmo e no próprio trabalho" (Souza, 2010.p. 50).

Essa classe trabalhadora é resultado da recente dominação do capitalismo financeiro na economia, na cultura e na política e é nova porque:

(...) a alocação e o regime de trabalho são realizados de modo "novo" de modo a ajustá-los às novas demandas de valorização ampliada do capital financeiro. Isso é conseguido, por exemplo, pela eliminação dos custos com controle e vigilância do trabalho. Essa nova classe trabalhadora labuta entre 8 e 14 horas por dia, e imagina, em muitos casos, que é patrão de si mesma. O real patrão, o capital tornado impessoal e despersonalizado, é invisível agora, o que contribui imensamente, para que todo o processo de exploração do trabalho seja ocultado e tornado imperceptível. Vitória magnífica do capital que, depois de 200 anos de história do capitalismo, retira o maior valor possível do trabalho alheio 
vivo, sem qualquer despesa com a gestão, o controle e a vigilância do trabalho. Destrói-se a grande fábrica fordista e transforma-se o mundo inteiro numa grande fábrica, com filiais em cada esquina [oficinas, indústrias de fundo de quintal, trabalho autônomo], sem lutas de classe, sem sindicatos, sem garantias trabalhistas, sem greve, sem limite de horas de trabalho e com ganho máximo ao capital. Esse é o admirável mundo novo do capital financeiro! (Souza, 2010. p. 57).

Assim a classe trabalhadora é mais ampla que o proletariado industrial produtivo do século passado, ela tem uma conformação mais fragmentada, mais heterogênea e mais complexa.

Nessa perspectiva, a atual situação de vulnerabilidade social está associada não somente à exclusão do mercado de trabalho mas também à inclusão precária que muitas vezes é obtida por meio de criação de empregos sendo que a qualidade das ocupações geradas pouco importa (Pochmann, 1999). Tal realidade traz uma situação contraditória, ao mesmo tempo em que se exige uma maior escolaridade e qualificação para o trabalho, os postos oferecidos constituem empregos mal qualificados e de baixa remuneração.

Assim, por um lado, a educação continua ainda condição necessária para o emprego da mão-de-obra pois a oferta de trabalho tende a estar mais identificada com a busca de maior qualificação profissional e a escolaridade mantém-se recurso inadiável de elevação da qualidade da mão-de-obra, já que há correlação direta entre baixa escolaridade e baixa qualidade ocupacional (Pochmann, 1999). Por outro lado, a escolaridade não garante estabilidade no trabalho pois entre 1992 e 2002, a taxa de desemprego subiu a um ritmo mais rápido nos níveis de maior escolaridade. Para os indivíduos com catorze anos de estudo, por exemplo, a variação de desemprego no período foi de $76,9 \%$ - uma diferença três vezes maior para aqueles que têm até três anos de estudo. Ao contrário do que prevê a teoria do capital humano, a análise de Pochmann (2006) revelou que os mais escolarizados, no Brasil, são os mais penalizados no interior do mercado de trabalho.

Cabe aqui a discussão sobre os problemas da política de formação/qualificação profissional. Segundo Souza (2006), tais problemas começam já a partir dos objetivos das políticas especialmente no que diz respeito à relação entre escola e mundo do trabalho. Em lugar de integrar escola e trabalho, a 
proposição contida no decreto 2208/97 - que regulamenta os artigos 36 e 39-42 da LDB- restringe-se à mera divisão do trabalho educacional, em que cabe à educação profissional o papel de fornecer a qualificação social - na forma de conhecimento e habilidades gerais para o exercício de atividades produtivas - necessária para jovens e adultos se adaptarem às novas demandas de produtividade e competitividade. Além dessa função, também à educação profissional cabe a formação técnicooperacional - na forma de aquisição de conhecimentos e habilidades específicas para o exercício de atividades produtivas. À empresa cabe a tarefa de treinar o trabalhador já formado/qualificado pela rede de educação profissional, de acordo com as necessidades produtivas de uma função específica. A relação entre escola e empresa prevista no Decreto 2.208/97 simula a relação existente entre o cliente (empresa) e o fornecedor de serviços (escola). Nessa relação, a escola de educação profissional cumpre uma dupla função. Além de formar quadros minimamente qualificados para ocupar os escassos postos de trabalho, também serve de instrumento de conformação de classe para contingentes cada vez maiores de trabalhadores desempregados, na medida em que transfere para o trabalhador certificado por ela a responsabilidade de seu sucesso ou fracasso no mercado de trabalho (Souza, 2006).

A qualificação do trabalhador, assim, fica submetido às leis do mercado, sendo que o trabalho e o saber produzidos se subordinam a essas lógicas instrumentais e perdem o seu princípio educativo (Brito, 2007). Para o capital, tornase necessário um trabalhador mais "qualificado", ou seja, mais de acordo com as necessidades comerciais e que seja melhor aproveitado possível para que a acumulação de torne cada vez maior (Brito, 2007).

Outro ponto a ser ressaltado é a inserção das diferentes classes no ensino superior. Se para as classes com formas de reprodução mais estáveis a escolha do curso a ser seguido já começa na formação fundamental e existe a possibilidade da escolha de uma carreira, para as classes populares a inserção no curso superior não depende do curso que o indivíduo vai escolher pois essa é apenas uma forma de tentar garantir a entrada no mercado de trabalho (Brito, 2007).

Independente da inserção de classe a sociedade valoriza o ensino superior como instrumento de ascensão social que possibilitaria maiores chances de emprego. Tal ideologia se apresenta com maior intensidade diante do aumento dos níveis de 
desemprego ao mesmo tempo em que atividades mais diversificadas e especializadas são geradas exigindo maior incorporação de elementos técnicos (Brito, 2007).

O medo do desemprego e a questão da qualificação para o trabalho ideologicamente disseminada faz os trabalhadores procurarem mais intensamente os cursos superiores. Entretanto, as políticas públicas não se voltam para a geração de vagas e as instituições privadas ganham espaço oferecendo uma formação meramente mercadológica e instrumental que não resolve a questão do desemprego pois o problema não se restringe à falta de qualificação mas sim à oferta de empregos (Brito, 2007 ).

No que diz respeito às políticas públicas, ressalta-se a proposta de governo de Fernando Henrique Cardoso, marco da instauração definitiva da política neoliberal no Brasil, em que a educação assumiu, assim, um caráter de instrumento de competitividade e produtividade industrial, pilares do neoliberalismo. Coube à Secretaria de Formação e Desenvolvimento Profissional (Sefor) construir gradativamente o Plano Nacional de Qualificação do Trabalhador (Planfor) (Souza, 2006).

Segundo Cêa citada por Souza (2006), o Planfor é definido como um instrumento de execução das políticas públicas de emprego que expressa o campo principal da educação profissional, materializando-a como modalidade educacional. $\mathrm{Na}$ avaliação da autora, o Planfor opera e ruptura entre qualificação para o trabalho e elevação dos níveis de escolaridade. O que o governo propunha como superação da dicotomia educação escolar e formação profissional era a divisão do trabalho educativo na formação do novo trabalhador, na qual à educação básica competia a formação de competências sociais - conformação ético-politica do trabalhador - e à educação profissional cabia a responsabilidade pela a formação de competências técnico-operacionais- conformação psicofísica do trabalhador. De posse desse arsenal de competências, restava à empresa apenas o acionamento de suas estratégias gerenciais para consolidar a captura da subjetividade operária em favor da valorização do capital (Souza 2006).

A engenharia inaugurada pelo Planfor instaurou um dos mecanismos mais eficientes de mediação do conflito de classe da burguesia. Em nenhum outro ocorreu tanta eficácia na conquista do consenso em torno da concepção burguesa de produção e reprodução social da vida material. Por meio do Planfor, a burguesia 
conseguiu conquistar o consentimento dos trabalhadores em torno de suas políticas públicas de trabalho e renda. Assim, o projeto educativo do empresariado tem se tornado cada vez mais hegemônico, em detrimento do projeto de integração entre educação e trabalho historicamente construído na luta dos trabalhadores contra o capital (Souza, 2006).

A ação sindical, por sua vez, constitui o consentimento ativo dos trabalhadores organizados em torno da política de formação/qualificação profissional que tem como foco as demandas do mercado e que busca na complementaridade entre educação básica e educação profissional as condições básicas para conformar a classe trabalhadora tanto no espaço psicofísico - qualificação profissional - quanto no espaço tecno-político - qualificação social. Assim, a nova política de formação profissional materializada no Planfor constitui um instrumento privilegiado de manutenção de hegemonia do bloco no poder, na medida em que serve de mecanismo de construção do consenso em torno da concepção burguesa de formação de trabalhador. Desse modo, a burguesia tem conseguido consolidar sua hegemonia no campo educacional restabelecendo as leis de mercado como norteadoras dessa relação, contando com o consentimento ativo das centrais sindicais, nas condições de parceira privilegiadas. $\mathrm{O}$ resultado concreto disso é a manutenção do monopólio do conhecimento por parte da burguesia, na medida em que, por intermédio do Planfor, se instituíram limites à unidade entre ciência e vida e entre educação e trabalho. (Souza, 2006).

Diante dessa discussão, verifica-se que o enfrentamento dos problemas que afetam o mundo do trabalho (desemprego, precarização, reduções salariais, elevação da jornada de trabalho, problemas das políticas de qualificação do trabalhador) dificilmente poderá ser realizado por meio de políticas limitadas ao mercado de trabalho. No Brasil, a experiência das políticas de emprego é muito recente. Durante o ciclo de industrialização nacional, a ausência de políticas de emprego não impediu que o país apresentasse uma dinâmica positiva de geração de emprego, mesmo sem ter resolvido os graves problemas tradicionais do mercado de trabalho (baixos salários, subemprego, informalidade e heterogeneidade nas ocupações). Mas nos anos 90, com a difusão de várias experiências de políticas de emprego, o resultado do ponto de vista ocupacional não se tornou generalizadamente positivo. Pelo contrário, com o abandono do projeto de industrialização nacional e o ingresso numa fase de 
especialização competitiva, a desestruturação do mercado de trabalho nacional se acentuou (Pochmann, 1999).

Soma-se a isso o fato de que a generalização das políticas neoliberais tende a caracterizar o sindicato e as demais organizações de trabalhadores como elementos do atraso, que dificultam o livre jogo das forças de mercado. As alterações no mercado de trabalho contribuem ainda mais para fragilizar a organização dos trabalhadores. Ao fragilizar a base de garantia dos direitos do trabalho e de proteção social, coloca-se em risco a solidariedade das classes trabalhadoras. Com a escassez de empregos e a ampliação da concorrência nos mercados, trabalhadores de outras empresas podem ser vistos como concorrentes e empresa como uma corporação capaz de atender plenamente seus anseios. Assim, o avanço da desordem econômica e das políticas neoliberais ocorre simultaneamente à diferenciação e desaglutinação dos interesses dos trabalhadores. Por isso, tudo, talvez um dos maiores desafios dos sindicatos seja hoje o de representar, de fato, os interesses do conjunto dos trabalhadores, somando esforços na construção de um novo projeto político nacional em conjunto com outros segmentos sociais.

Diante dessa realidade, Pochmann (1999) aponta para cinco alternativas de políticas ativas que deveriam ser implementadas: a) projeto nacional com linhas gerais de crescimento econômico sustentado com justiça social tendo o emprego como questão central; b) reforma agrária gerando empregos e renda no campo; c) desconcentração de renda por meio de apoio aos pequenos negócios e trabalhadores de serviços pessoais (barbeiros, encanadores, eletricistas, entre outros); d) investimentos em infra-estrutura material (escolas, saneamento básico, habitações populares) que gerariam impactos diretos sobre a geração de emprego e renda; e) incremento das atividades de serviço social como programas de trabalho de utilidade coletiva (frentes de trabalho urbana e rural), ampliação das atividades entre parcerias e comunidades de assistência e prestação de serviços, programas de estágios. $\mathrm{O}$ autor aponta também para quatro alternativas de políticas compensatórias como: a) medidas de formação e qualificação profissional, b) ampliação da idade mínima para o jovem ingressar evitando a exploração do trabalho do menor, reduzindo a oferta de mão de obra e valorizando-a; c) reformulação do sistema de seguro desemprego (diferenciação dos benefícios segundo o perfil do desempregado e criação de programas de integração salarial); d) introdução de um sistema democrático de 
relações de trabalho, que poderia contribuir para evitar a precarização dos empregos e a rotatividade, por meio, por exemplo, de contratação coletiva que tenderia impor maior responsabilidade às entidades sindicais e empresariais no que se refere a qualificação profissional, à ampliação do tempo de serviço na mesma empresa e à redução da informalidade.

Reafirma-se que essas alternativas não se restringem a políticas relacionadas apenas ao mercado de trabalho nacional. Devem ser constituídas políticas públicas setoriais, nacionais e internacionais capazes de assegurar que a competitividade (pilar das políticas neoliberais) não se faça à base de redução de salários e ampliação do desemprego, da precarização, da jornada de trabalho e da desigualdade social. (Pochmann, 1999).

\subsection{Dimensão do consumo}

A discussão do processo de produção capitalista relacionada às formas de produzir de uma determinada sociedade leva inevitavelmente à discussão do momento do consumo, ou seja, às formas de uma sociedade consumir o que foi produzido considerando-se a perspectiva das relações que o indivíduo, a família e a classe social a qual pertencem estabelecem com outras pessoas, outros grupos e com as instituições do território onde vivem, além das condições de ocupação desse território com suas características geográficas, sociais e ambientais.

Wright (1997) afirma que no nível micro a classe explica a definição por interesses, capacidades estratégicas e experiências das pessoas e cada um desses efeitos depende não somente da posição de classes de uma pessoa em uma estrutura de classe ocupacional, mas também pelos complexos caminhos pelos quais suas vidas estão ligadas a várias classes através de carreiras, mobilidade, associações voluntárias e laços sociais.

Marques et al (2011) em estudo sobre redes sociais em Salvador e em São Paulo verificaram que as mais relevantes estão ligadas à práticas religiosas e estão presentes nas áreas mais segregadas socialmente. O estudo identificou também que as redes de indivíduos pobres tendem a ser menores, menos variadas em termos de sociabilidade em comparação às redes dos indivíduos de classe média. Ressalta-se que outros autores como Sorj e Martucelli (2008) identificaram que o isolamento 
social é particularmente grave nos bairros que concentram trabalhadores de baixa qualificação e com vínculos frágeis com o mercado de trabalho, porque a pobreza de acesso a informações e contatos que os caracteriza se soma à redução das oportunidades de interação com os que possuem informação e contatos úteis para o acesso ao mercado.

Retomando o estudo de Marques et al (2011), verificou-se que 20\% dos entrevistados em São Paulo e Salvador eram protestantes pentecostais, 63\% católicos em São Paulo e 45\% em Salvador que tem também 5\% de seguidores do candomblé.

Sorj e Martucelli (2008) afirmam que na América Latina tanto a religião institucional como a religiosidade se constituem em fonte fundamental da coesão social, tanto como suporte individual como elemento presente na construção da cultura e da política. Além de fortalecer os universos simbólicos compartilhados coletivamente, as práticas religiosas desempenham também a função de espaços de agregação social, de fortalecimento dos laços sociais. As redes sociais relacionadas com a igreja se transformam em uma importante fonte de informação inclusive sobre oportunidades de emprego, até no exterior, em que muitas vezes católicos se "convertem" ao pentecostalismo para se aproximar de igrejas pentecostais onde se reúnem seus compatriotas e se inserem em redes de solidariedade (Sorj, Martucelli; 2008).

Ressalta-se que o cristianismo mantém-se impregnado nas sociedades latinoamericanas integrando o tecido social cotidiano dos subcontinentes, pois um grande número de eventos nacionais e regionais bem como feriados se inscrevem em suas tradições e são pautados pelo calendário litúrgico. (Sorj, Martucelli; 2008).

As igrejas evangélicas alcançam $12 \%$ das identificações religiosas dos países latino-americanos sendo $70 \%$ do segmento pentecostal. O pentecostalismo se volta em direção às diferentes camadas sociais, mesmo que os mais pobres e desfavorecidos sejam seus principais seguidores, constatação que se apresenta também no presente estudo em que o grupo social IV tem uma porcentagem discretamente maior de pentecostais. Nas últimas décadas vem ocorrendo crescimento das igrejas evangélicas, muitas delas originárias da região latinoamericana, que demonstraram uma enorme capacidade de empreendedorismo criando impérios de comunicação (Sorj, Martucelli; 2008). 
Os autores reforçam que a sociedade e culturas latino-americanas são possuidoras de uma lógica que admite e reconhece a religião e as religiosidades enquanto instâncias de mobilização e formação social, ao contrário das modernas repúblicas européias secularizadas, onde se verifica a tendência de restringir o religioso à esfera da subjetividade e do privado.

Por outro lado, as funções da igreja e do Estado se confundem pois nas regiões periféricas em que a oferta de serviços públicos é muito precária, grupos religiosos dão assistência à população mais carente como afirmado em artigo do Jornal Estado de São Paulo. ${ }^{7}$

Desde os missionários jesuítas, na colonização do Brasil, passando pelas Santas Casas de Misericórdia, escolas adventistas e Pastoral Carcerária, que oferece assistência judicial, e assim por diante, a Igreja tem assumido o papel do Estado onde ele está ausente ${ }^{8}$.

Essa realidade justifica a força das igrejas evangélicas nas periferias das grandes cidades, em que os serviços de saúde são precários, as escolas funcionam mal, não há saneamento nem lazer. Assim, poder-se-ia dizer que o Brasil se caracteriza por apresentar um centro católico, ou protestante tradicional (luteranos, metodistas, presbiterianos e batistas, que têm nível de renda e escolaridade acima da média) e uma periferia pentecostal (Assembléia de Deus, Congregação Cristã do Brasil e Igreja Universal do Reino de Deus são as maiores $)^{9}$.

Segundo Souza (2010), o pentecostalismo realmente se configura em uma forma tipicamente moderna de religiosidades das classes dominadas, em sintonia com as formas modernas de exclusão e dominação engendradas pelo capitalismo. $\mathrm{O}$ seu discurso e prática são produzidos pelas teias sociais da sociedade capitalista. A religião pentecostal não se ocupa apenas dos indivíduos mas das famílias e, ao "congregar o horizonte econômico com o horizonte de socialização em interações", a religião pentecostal lida com o "mundo da vida" de uma determinada classe de pessoas (Souza, 2010.p. 308).

\footnotetext{
${ }^{7}$ Igrejas assumem papéis que seriam do Estado. Jornal Estado de São Paulo, São Paulo, 10 out. 2010 [citado 30 ago. 2011]. Disponível em : http://www.estadao.com.br/estadaodehoje/20101010/not_imp623107,0.php.

${ }^{8}$ Ibidem

${ }^{9}$ Ibidem
} 
O jornal Estado de São Paulo apresenta dados da pesquisa realizada pela Fundação Getúlio Vagas em 2007 que identificou que mesmo ganhando menos, os pentecostais doam mais dinheiro para suas igrejas do que os católicos. O dízimo e outras contribuições recebidas pelas igrejas pentecostais representam $44 \%$ de todas as doações a todas as igrejas no País, enquanto que os católicos pagam 31\%. Num certo sentido, o dízimo substitui o imposto, acrescido de uma certa alegria, de uma sensação de compensação pelos serviços efetivamente prestados, ao contrário da relação do contribuinte com o Estado brasileiro. Assim, a igrejas estabelecem com a população pobre a mesma relação que as oligarquias políticas locais nos moldes do clientelismo. Isso não significa que essas instituições tenham de agir de forma coercitiva, obrigando-os a votar nesse ou naquele candidato. Ao contrário, os fiéis seguem a orientação de seus pastores e padres com naturalidade e a igreja não é apenas um lugar para atender as necessidades espirituais de seus fiéis: se constitui em rede social, lhes proporciona lazer, amizades, contatos para empregos e informação sobre tudo - incluindo em quem devem ou não votar ${ }^{9}$.

Sendo assim a questão da freqüência a cultos passa a ser considerada pela população mais excluída como forma de lazer e tem sido já identificada, inclusive no presente estudo.

Isso não somente porque as igrejas pentecostais se concentram na periferia, mas porque a periferia também apresenta poucas formas de lazer.

As grandes cidades latino-americanas caracterizam-se por ser altamente mediáticas e concentradas, nas quais a diversão também tem a sua geografia. Os restaurantes, bares, cinemas, teatros e salas de concerto ficam no entanto limitados a uma faixa estreita da cidade (Sorj, Martucelli; 2008). É necessário reconhecer que o espaço urbano reflete sociedades diferenciadas e heterogêneas (Sorj, Martucelli; 2008).

O aprofundamento das distâncias econômicas e os novos fenômenos de exclusão e segmentação social projetam um panorama na vida cidadã como por exemplo, a mudança nas formas de consumo do cinema: declínio das velhas salas de exibição nos bairros (hoje convertidos em igrejas evangélicas) e surgimento dos cinemas de última geração de cadeias internacionais e mais caros (Sorj, Martucelli; 2008)

${ }^{10}$ Ibidem 
A questão do lazer nas metrópoles também pode ser discutida a partir de outra perspectiva, a que considera a forma como o sistema capitalista se apropria das horas de folga dos trabalhadores.

Existem duas possibilidades de se compreender lazer segundo Marcellino citado por Nishimura e Thomassim (2008): a linha que considera "atitude" ligada a estilos de vida que se refere à relação que o indivíduo tem com a experiência vivida, sendo que até o trabalho pode se apresentar como forma de lazer se for gratificante e escolhido pelo trabalhador; e a outra linha, a de "tempo" liberado do trabalho e de outras obrigações familiares, considerado assim "tempo disponível" (Nishimura, Thomassim, 2008).

Mascarenhas citado por Nishimura e Thomassim (2008) propõe uma divisão do lazer pago: os "com lazer" ricos e endinheirados que podem pagar pelo melhor da mercadoria e estilos de vida (...), os "mais ou menos com-lazer", em sua maioria tendo contato com o mais barato (...) e os do "quase-sem"e dos "sem lazer", dos pobres e dos miseráveis na base da pirâmide (Nishimura, Thomassim, 2008).

Bernardo (2000) contribui para a discussão nos apresentando mais uma perspectiva: a de que na sociedade contemporânea os trabalhadores produtivos deixaram de passar as suas horas de ócio fora do âmbito da economia capitalista. Nos países e regiões economicamente mais desenvolvidos, a reconstituição da força de trabalho e a produção de novos trabalhadores passou a fazer-se inteiramente ou quase inteiramente dentro da esfera do capitalismo que abarca os bens e serviços consumidos nas horas de folga, produzidos antes no âmbito doméstico ou em pequenas empresas de caráter familiar. "O capitalismo apoderou-se das grandes oportunidades de mercado oferecidas pelos ócios"(Bernardo, 2000). Além disso, o tempo de lazer se transformou em um período de formação da força de trabalho (Bernardo, 2000):

Se observarmos bem, deparamo-nos com algo de aparentemente paradoxal. Por um lado, o aumento das qualificações do trabalhador implica o acréscimo do tempo de trabalho despendido durante a mesma jornada de trabalho e, portanto, requer períodos de descanso mais longos, para que a força de trabalho não se extenue e não deteriore as suas potencialidades. Por outro lado, porém, o aumento das qualificações só pode ocorrer se se prolongar o tempo de formação dos trabalhadores, ou seja, se se ampliar o prazo necessário para eles obterem as novas qualificações. Estas duas exigências são incompatíveis, a não ser que se sobreponham. E foi assim que os lazeres ficaram convertidos numa oportunidade de qualificação da força de trabalho (Bernardo, 2000, p. 35). 
Entretanto, segundo o autor, os ócios são hoje mais do que isso. Não se trata apenas de contribuir para que o trabalhador adquira novas qualificações. Trata-se de produzir o próprio trabalhador como produto do capitalismo. Os bens e serviços que o trabalhador consome durante o ócio resultam dos mais estritos critérios da produtividade capitalista, o que significa que o próprio trabalhador, ao consumir estes bens, está se transformando em produto do capitalismo. Na Europa ocidental, nos Estados Unidos e no Japão a esmagadora maioria dos trabalhadores passa as suas férias em viagens organizadas ou em campos de férias que em nada se diferenciam da estrutura vigente nas modernas empresas fabris ou de serviços (Bernardo, 2000).

Outros autores como Nishimura e Thomassim (2008), abordaram a questão do lazer estudando a relação entre trabalho e lazer na periferia e verificaram que o excesso de carga de trabalho durante a semana e inclusive aos finais de semana representam barreiras para a participação em espaços coletivos nas horas de folga.

Muitas dessas famílias utilizam esses períodos inclusive para a construção da própria casa o que significa concretamente consumo de forças de trabalho sem reposição de energia gasta no trabalho cotidiano (Bonduki, Rolnik; 1982). O resultado é a diminuição do ciclo produtivo do trabalhador e de sua expectativa de vida, desgaste esse que a propriedade da moradia não consegue recuperar. Essa negligência com a reprodução da força de trabalho só tem sido possível devido a um forte controle político e à manutenção de um amplo exercito industrial de reserva (Bonduki, Rolnik; 1982)

A construção da casa nas periferias se baseia principalmente no mutirão de fins de semana e na construção por etapas. O mutirão contribui indiretamente para manter baixos salários e acaba por estender a jornada de trabalho diminuindo o tempo de lazer, caracterizando-se ainda, por ser simplesmente uma contraprestação de serviços, onde um morador ajuda o outro na expectativa de ser auxiliado quando precisar. Assim, a visão mitificadora que apontava o mutirão como exemplo de solidariedade de classe vai perdendo suas cores (Bonduki, Rolnik; 1982).

Esse processo de construção da casa ocorre em etapas. Em muitos casos o barraco é a primeira habitação que o morador constrói no lote, imediatamente após sua compra. A urgência em se livrar do aluguel, ou de deixar a moradia cedida, 
justifica esta primeira etapa, uma vez que um barraco pode ser erguido numa noite e custa pouco em relação a uma casa de alvenaria (Bonduki, Rolnik; 1982).

Verifica-se no presente estudo que a maior parte das famílias do grupo IV - o mais excluído - possuem casa própria mas que apresenta principalmente a característica de autoconstrução acabada ou inacabada conforme verificado em campo durante a coleta dos dados.

Dessa forma, para se desfazer da preocupação de pagar o aluguel os trabalhadores se desgastam na construção de suas casas. Nettleton, Burrows (1998) discutem a relação entre insegurança de moradia e a conseqüência sobre a saúde dos proprietários norte-americanos que entraram em dívidas devido à hipoteca. Os autores avaliam também a utilização dos serviços de saúde de atenção primária e ressaltam que a literatura tende a focar os impactos dos aspectos físicos da casa sobre a saúde e que a questão da acessibilidade à moradia é relativamente inexplorada. Afirmam que a preocupação em manter os pagamentos das hipotecas tem trazido muita ansiedade pois está relacionado ao receio de perder a casa (Nettleton, Burrows, 1998). Verifica-se assim a importância da propriedade da residência se constituir em variável que componha o IRS e apóie a construção dos perfis epidemiológico de um território.

Os mesmos autores afirmam que dívidas com hipoteca assim como a doença são socialmente determinadas, pois as classes sociais mais excluídas têm mais chance de se endividarem. Chamam a atenção para o fato de que famílias chefiadas por jovens e por grupos étnicos, famílias com crianças pequenas, homens solteiros, divorciados, correm maior risco de se endividarem com a hipoteca. Também estão em maior risco os indivíduos freqüentemente inativos economicamente e os autônomos em comparação com os estavelmente empregados. Ressaltam que o endividamento está relacionado com fatores estruturais (razão entre renda/empréstimos, subsídios do governo, taxas de juros, níveis de suporte e de segurança social), renda familiar e elementos associados (desemprego na família, doença, divórcio, empregos de curta duração, reparos inesperados, dividas não planejadas) e fatores pessoais (habilidade para gerenciar o dinheiro considerando as despesas da casa e prioridades pessoais) (Nettleton, Burrows, 1998).

Os resultados da pesquisa sugeriram que o início do endividamento com hipotecas estava associado com alta pontuação em um instrumento utilizado para 
caracterizar a saúde mental. Os indivíduos apresentavam maior ansiedade e sentimentos de insegurança levando ao aumento das taxas de consultas aos médicos da atenção primária (Nettleton, Burrows, 1998).

A relação entre moradia e saúde poder ser avaliada a partir de outra perspectiva considerando-se as características das moradias construídas pelos próprios moradores. Esse longo processo de construção da casa nos dias de folga, condicionado pela obtenção de uma difícil poupança faz com que a casa seja um bem permanentemente inacabado e construído em etapas descontínuas, não sem graves conseqüências para sua habitabilidade (Bonduki, Rolnik; 1982).

No Brasil, o Estado tem buscado tornar-se mínimo em relação aos encargos sociais, entre eles a habitação. Desta forma, os loteamentos periféricos, empreendimentos privados que obtêm lucro em função da especulação imobiliária e das péssimas condições oferecidas agem sobre o "problema" sem uma interferência mais direta e imediata do poder público. Mas esta ausência do poder público envolve ainda outras vantagens. A ela estão ligados a autoconstrução e a obtenção da propriedade. Através da autoconstrução, o trabalhador constrói sua casa nas horas de folga, com outros trabalhadores que, como ele, não recebem pelo trabalho. Ressaltase ainda as condições precárias das casas em loteamentos periféricos: ausência de revestimentos, banheiros fora de casa, lotes congestionados, várias casas por lotes, entre outros (Bonduki, Rolnik; 1982).

A maior parte das casas implantadas nas ocupações e loteamentos periféricos é construída pelos próprios moradores, com pouca ou nenhuma assistência técnica, em permanente estado de não acabamento. Essas moradias informais sofrem ampliações e rearranjos em função das necessidades familiares que mudam conforme os ciclos de vida dos seus respectivos membros. Quando os filhos e filhas se casam, é comum as famílias aumentarem as casas para acomodar o novo casal. Muitas vezes essa ampliação prejudica a ventilação e insolação nos cômodos gerando situações insalubres que provocam doenças respiratórias (Nakano, 2007).

Os agentes imobiliários capitalistas não se interessam por um investimento pouco rentável e os recursos manipulados pelo Estado são prioritariamente dirigidos à reprodução do capital, e, no que se refere à habitação, voltados para as camadas de renda média e alta. Assim, é a própria classe trabalhadora que assume o ônus de sua reprodução no tocante à habitação, por meio de autoconstrução da casa própria 
(Bonduki, Rolnik; 1982). Casas essas que geralmente são pequenas, apresentam infraestrutura precária e baixo valor monetário, elementos que podem ser identificados pela isenção do pagamento do IPTU ${ }^{\mathbf{1 1}}$. Destaca-se que no presente estudo mais de $40 \%$ das famílias do grupo IV não pagavam esse imposto.

Em geral, no início da construção da casa - seja de madeira ou de alvenaria o morador levanta dois cômodos de uma só vez. Apesar da expectativa ser um progressivo aumento do número de cômodos, não há via de regra o esperado crescimento da casa, o que se justifica pelo custo deste empreendimento e assim, independentemente do tamanho da família, as casas apresentam poucos cômodos (Bonduki, Rolnik; 1982).

Dessa forma, o número de cômodos também se apresenta como importante elemento qualificador da habitação. No presente trabalho verificou-se que o grupo social I (mais incluído) apresentava a maior quantidade de cômodos para dormir (três ou mais) em contraposição aos outros grupos sociais. Assim, as duas variáveis isenção do IPTU e número de cômodos - estão relacionadas com as características da habitação cuja relação com a saúde vem sendo tradicionalmente apontada pelos estudos epidemiológicos e que compõe também o conjunto de variáveis da dimensão do consumo do IRS.

Retomando-se a discussão a respeito da casa própria, segundo Bonduki e Rolnik (1982), esta se constitui numa forma encontrada pelo trabalhador de deixar de pagar o aluguel que consome grande parte de seu baixo salário e não se constitui em pagamento de aquisição do imóvel. Como o salário é insuficiente frente às despesas referentes ao orçamento do trabalhador, este busca eliminar gastos monetários mediante a produção de valores de uso. Pressionados pelos crescentes gastos monetários o trabalhador procura eliminar o gasto mensal com habitação através da aquisição de uma casa própria. Embora a grande expectativa com a obtenção da casa própria seja a eliminação das despesas com habitação, durante vários anos o

\footnotetext{
11 IPTU: Imposto Predial Territorial Urbano. Pela lei 8292/2001 a moradia que apresentar valor venal até 25.700,00 FMP, será isenta. Acima desse valor até o valor de até 30.333,33 FMP o IPTU será inferior a 7,00 FMP e também será isento (lei 8463/2002). A isenção ocorre também para as moradias atingidas por enchentes (Lei 9.111/08 e Dec. 15.965/09). O FMP (fator Monetário Padrão em 2011 é de 2,5034 , em 2010 foi de 2,37 reais,em 2009 de 2,274 reais e em 2008 foi de 2,1374 reais. Fonte: http://www2.santoandre.sp.gov.br/service/1686:
} 
trabalhador tem uma série de gastos na sua aquisição, em geral superiores às suas possibilidades.

A casa própria encaixando-se perfeitamente nessa conjuntura de super exploração da força de trabalho, e atendendo aos interesses da especulação imobiliária, é a alternativa que resta ao trabalhador. E com ela, todas as suas consequiências na desorganização do espaço urbano, pois uma cidade conformada por interesses de agentes individuais capitalistas apresenta apenas a racionalidade do lucro (Bonduki, Rolnik; 1982).

Os loteamentos periféricos geram uma cidade horizontal e desconcentrada que se estende sem medidas, apresentando um padrão de crescimento urbano que não atende aos interesses do morador de baixa renda, pois com ele eleva-se o custo unitário da instalação de equipamentos e aumenta-se o tempo desperdiçado no deslocamento casa-trabalho, conseqüências que só podem piorar o nível de vida dos trabalhadores (Bonduki, Rolnik; 1982).

Ressalta-se a alteração da composição social do bairro e o movimento que leva as camadas menos remuneradas da força de trabalho a habitarem sempre parcelas do território urbano mais desprovidas de serviços, equipamentos e transportes. Assim, se configura uma cidade ocupada diferencialmente pelas classes que se apropriam de parcelas do território de acordo com o nível de renda a que têm acesso. Nesse sentido, não existe uma única periferia uniforme, mas muitas, com características diferentes, pois mesmo dentre os territórios da cidade com dificuldade de acesso aos serviços básicos, há uma graduação e uma hierarquização muito grandes, desde os que não tem ruas até os que tem água e não asfalto, etc. E será entre essas periferias que a população de baixa renda se deslocará, de uma periferia para outra mais carente, "reproduzindo seu espaço para reproduzir sua força de trabalho" (Bonduki, Rolnik; 1982).

Sorj e Martucelli (2008) chamam a atenção para o fato de que a organização social do espaço das grandes cidades acentuou a crescente separação territorial entre os segmentos excluídos do mercado de trabalho dinâmico e o resto da cidade. Essa organização social do território das grandes cidades tem como consequiência uma diminuição das oportunidades de interação social entre os diferentes e os desiguais nas ruas e nas instituições que prestam serviços coletivos com base territorial, tais como: educação, saúde, transporte e lazer. Esses serviços se segmentam através de 
diversos mecanismos. Por um lado, pelos impactos que os processos de segregação residencial têm sobre a capacidade dos grupos sociais de contribuir via tributos para o financiamento desses serviços. Isso porque a reunião de uma população pobre nos territórios nos municípios periféricos tende a gerar serviços coletivos locais de baixa qualidade utilizadas unicamente por esses segmentos. Por outro lado, os segmentos de classe média mais favorecidos pelas novas modalidades de acumulação são propensos a adquirir no mercado serviços básicos, principalmente educação, saúde, previdência social e segurança pública (Sorj, Martucelli; 2008).

Os serviços de infra-estrutura não são implantados de maneira a acompanhar a formação de novos bairros nos loteamentos. O processo de implantação de infraestrutura ocorre descontinuamente aos saltos, sendo que, quando acontece, cobre uma grande área de uma vez só. E isto porque os investimentos feitos pelo poder público em bairros de população de baixa renda dependem muito mais de conjunturas políticas do que de um processo de planejamento. Atualmente, os investimentos estatais têm dado prioridade aos setores mais vitais de acumulação, principalmente transportes e energia, e ao próprio financiamento das empresas, em detrimento da reprodução da força de trabalho. Desta forma, equipamentos urbanos não são oferecidos uniformemente para toda a cidade, privilegiando as parcelas habitadas pelas faixas de renda média e alta. Para a habitação de baixa renda inexiste subsidio de unidades prontas e a implantação dos bens de consumo coletivos em loteamentos periféricos, quando ocorre, está sempre em atraso (Bonduki, Rolnik; 1982).

Nakano (2007) afirma que a urbanização desigual da RMSP possui relação com os padrões excludentes de repartição da renda e da riqueza local e nacional. As desigualdades sócio territoriais presentes nessa grande metrópole inserem-se nos mesmos processos sócio políticos que levam à concentração e às desigualdades na distribuição de renda e de poder nos diferentes grupos sociais. Essas desigualdades contrapõem dois extremos: de um lado os grupos detentores de privilégios e riquezas que habitam os melhores locais do ponto de vista urbanístico, de maior valor para o mercado imobiliário, de outro os grupos que vivem em situações de pobreza e miséria, nos locais com péssimas condições de moradia e com pouco ou nenhum acesso aos benefícios coletivos como, por exemplo, bons serviços de saúde, educação, cultura e transporte, entre outros (Nakano, 2007). 
Grande parte das áreas periféricas de São Paulo é construída principalmente a partir de quatro elementos: a) ocupações de terras vazias realizadas por grupos de baixa renda, b) loteamentos irregulares e clandestinos comercializados ilegalmente, c) conjuntos habitacionais para a população de baixa renda produzidos pelo poder público e d) favelas. A insuficiência do abastecimento de água, esgotamento sanitário e equipamentos comunitários de educação, saúde, lazer entre outros, é o traço comum a esses assentamentos (Nakano, 2007).

Em vários bairros periféricos a oferta de infraestrutura urbana básica ocorreu com base em relações clientelistas entre moradores e candidatos a prefeitos e vereadores. Essas relações envolvem entre outras coisas a troca de votos pela promessa de investimentos urbanos realizados após vários anos. O clientelismo político, articulado com a urbanização precária enfraquece a construção de sujeitos de direitos e fortalece o assistencialismo. Para se ter uma idéia sobre a ampliação da oferta de infraestrutura básica da RMSP, vale observar os dados da PNAD 2005. Nesse ano, a RMSP possuía 5599624 domicílios urbanos dos quais 8,7\% apresentavam inadequação fundiária, 6,8\% tinham adensamento excessivo (mais de três pessoas por dormitório), 0,5\% não possuíam banheiro, 7,9\% apresentavam carência em infra-estrutura (energia elétrica, abastecimento de água, esgotamento sanitário e coleta de lixo) (Nakano, 2007).

No presente estudo verificou-se que o grupo IV (mais excluído) apresentava menos acesso à água, esgoto e luz. Quanto à legalidade desse acesso verificou-se que porcentagens consideráveis desses grupos não pagavam a conta por esses serviços. A falta de acesso oficial provoca grande desgaste dos moradores que não têm a quem recorrer caso ocorra algum problema com abastecimento ou necessidade de reparos na rede de água, de esgoto ou rede elétrica. Tal constatação da realidade corrobora a inclusão no IRS das variáveis relacionadas a acesso a saneamento para classificação das famílias.

Segundo Nakano (2007) existe problema na captação de água que é feita atualmente a quilômetros de distância da RMSP, inclusive em mananciais localizados no sul do Estado vizinho de Minas Gerais. O desperdício, a baixa reutilização da água, o não aproveitamento das águas pluviais e a contaminação dos rios, córregos, e reservatórios prejudicam a sustentabilidade dos recursos hídricos. Esse problema é agravado pelo baixo percentual de esgoto tratado na metrópole: 
somente $5 \%$ do total. Há muitas redes de esgoto que não estão conectadas aos coletores dos troncos das estações de tratamento. Essas redes somente afastam os efluentes líquidos domiciliares e industriais das casas e estabelecimentos não residenciais. Porém são lançados, sem qualquer tratamento prévio e em grande quantidade, nos corpos de água da metrópole, inclusive naquele usados em abastecimentos.

Barban (2009) apresenta dados do Fórum Mundial da Água realizado em 2009. Tem sido tema freqüente dos fóruns - que ocorrem a cada três anos desde 1997 - a discussão da água como mercadoria e a privatização dos serviços de água. Atualmente mais de 800 milhões de pessoas no mundo não têm acesso à água potável, enquanto 2,5 bilhões não têm saneamento adequado. A região metropolitana de São Paulo, com 18 milhões de habitantes situados na Bacia Hidrográfica do Tietê tem sido incapaz de satisfazer a demanda. Em São Paulo, o governo e a Sabesp, ao invés de cuidar do tratamento de água, tem um enorme projeto de trazer água desde o Vale do Ribeira. Uma obra de bilhões de dólares custeado pelo dinheiro público. Apesar da discussão a respeito da possibilidade de privatização dos serviços de água, no fórum houve recusa da maior parte dos países em reconhecer a água como direito humano. (Barban, 2009).

Bava (2004) aponta que a pressão pela privatização dos serviços de água e saneamento está aumentando. O Banco Mundial condicionou a concessão de empréstimos a alguns países à privatização desses serviços. O Brasil tem também sido pressionado já que possui os maiores reservatórios de água doce do mundo. Apesar do argumento ser sempre o mesmo de que a privatização possibilitaria a expansão desses serviços o que se observou em países latinoamericanos que passaram por esse processo foi exatamente dificuldade de acesso: os mais excluídos chegavam a gastar na Bolívia a metade do seu salário para comprar água.

No Brasil, estima-se que existam cerca de trinta municípios que já privatizaram esses serviços. A iniciativa mais expressiva talvez seja a do Governo do Estado do Amazonas, que em 2000 leiloou a Manaus Saneamento, responsável por 96\% das atividades da Companhia de Saneamento do Amazonas. Quem comprou a Manaus Saneamento foi a transnacional francesa Suez-Lyonnaise. Pagou R\$ 180 milhões, mas $50 \%$ destes recursos foram financiados pelo BNDES. Segundo especialistas, estes recursos teriam sido recuperados pela empresa em apenas 14 
meses de operação. A fonte destes recursos são as tarifas pagas pela população (Bava, 2005).

O histórico de investimentos em saneamento básico não é animador. Nos anos 70 ele foi de $0,34 \%$ do PIB; nos anos 80 foi de $0,28 \%$; nos anos 90 foi de 0,13\%. Em 2003 foram gastos apenas R \$ 60 milhões; em 2004 foram destinados R\$ 818,8 milhões, mas até o fim do ano tinham sido pagos apenas $\mathrm{R} \$ 53,6$ milhões e comprometidos outros $\mathrm{R} \$ 454,7$ milhões. Os recursos programados e não liberados foram para o pagamento dos juros da dívida pública. Além disso, as empresas que participam das privatizações têm financiado seus investimentos com recursos do BNDES e do FGTS, que poderiam ser direcionados para as autarquias municipais ou as companhias estaduais de saneamento (Bava, 2005)

Por outro lado, movimentos de resistência têm acontecido na América Latina. Em 2004, junto com as eleições presidenciais que elegeram um governo de esquerda no Uruguai, foi realizada consulta ao povo na forma de um referendum e $60 \%$ dos uruguaios decidiram fazer uma reforma na sua Constituição para garantir a água como um bem público. Não seriam assim feitas mais concessões às empresas privadas, criando-se uma companhia estatal para gerir estes recursos essenciais (Bava, 2004).

Nessa perspectiva, o acesso à água é considerado um direito humano fundamental. O abastecimento de água e o saneamento devem ser serviços públicos prestados pelo Estado. Estas são proposições da Plataforma Global da Água, documento elaborado por uma articulação de movimentos sociais do mundo inteiro, e são uma reação à onda de privatizações dos serviços públicos que transformam a água de um bem público em mercadoria (Bava, 2005). 


\section{Considerações finais:}

para fazer a síntese 


\section{9- Considerações finais: para fazer a síntese}

Nesse trabalho aceitou-se o desafio de operacionalizar o conceito de classe social por meio da categoria reprodução social na atualidade e em uma cidade metropolitana que passa por processo de desindustrialização. Assim, o objetivo do presente estudo - averiguar a capacidade das variáveis de trabalho e vida para mostrar as diferenças de reprodução social das famílias nos espaços do bairro e das ruas - foi alcançado.

Para tanto, percorreu-se o seguinte caminho:

1- Apresentou-se o campo da Epidemiologia Crítica como fundamento para investigações sobre o caráter social do processo saúde-doença; nessa perspectiva coloca-se no centro da explicação dos determinantes da saúde o trabalho - a produção capitalista - e, a ele subordinado, a vida - o consumo sob o comando do processo de acumulação capitalista. Considerou-se que é imprescindível para os estudos epidemiológicos que objetivam fornecer arcabouço teórico-metodológico e instrumentos para a transformação do processo saúde-doença do coletivo partir do conceito de classes sociais e de sua operacionalização

2- Tomou-se considerações teóricas a respeito do conceito de classes sociais segundo as três dimensões possíveis de sua abordagem e autores clássicos: estrutura econômica (Marx), status/estilo de vida (Weber, Bourdieu), ação social (Thompson). Assumiu-se o referencial marxista clássico e buscou-se identificar a utilização do conceito de classes sociais em investigações epidemiológicas na perspectiva da Epidemiologia Crítica.

3- Discutiu-se a operacionalização do conceito de classe por meio da categoria reprodução social partindo-se da proposta dos Grupos Sociais Homogêneos de Salum e Queiroz (1997, 2000, 2010). 
4- Levantou-se, através de inquérito domiciliar, dados de reprodução social de famílias que vivem em diferentes espaços sociais de uma cidade da RMSP- Santo André. Para tanto:

- Definiu-se variáveis empíricas que melhor representassem o conceito de reprodução social, tomado como central neste estudo;

- Elaborou-se o instrumento de coleta de dados, com posterior seleção da amostra; coleta, análise e interpretação dos dados;

5- Analisou-se o comportamento dessas variáveis de reprodução social quanto à sua capacidade para formar grupos com semelhantes formas de trabalhar e de viver;

6- Definiu-se quatro grupos sociais (I, II, III e IV) que se diferenciaram entre si por meio da relação entre as variáveis das formas de trabalhar (qualificação da ocupação, condição de atividade, curso preparatório para o trabalho e registro em carteira) e formas de viver (propriedade da residência, acesso a serviço público de esgoto, legalidade do acesso à água e luz, culto como atividade de lazer, pagamento de IPTU e número de cômodos para dormir). Quanto à variável condição de atividade e qualificação da ocupação ressalta-se que dada a divisão social do trabalho, as ocupações são definidas pela posição de classe do indivíduo.

7- Partiu-se das variáveis potentes para caracterizar os grupos e construiu-se o Índice de Reprodução Social - IRS - capaz de mostrar as diferenças de reprodução social entre as famílias no micro espaço (rua, setor censitário, bolsões de favela, ocupações). Tal índice é composto pela dimensão da produção (formas de trabalhar) e dimensão do consumo (formas de viver) com suas respectivas variáveis e pesos. Ressalta-se que os grupos sociais são homogêneos em seu interior e essa homogeneidade é dada pela relação entre os indivíduos que os compõe (no caso as famílias).

8- Verificou-se que as varáveis da dimensão da produção obtidas nesse estudo configuram-se em variáveis clássicas que atualmente ainda apresentam papel central na explicação da diferenciação entre grupos sociais, o que reforça a potencialidade da teoria marxista para explicar a realidade social na contemporaneidade. Realidade 
essa que, a despeito de diversos autores que defendem a superação da categoria trabalho na explicação das contradições na sociedade, ainda se pauta no modo de produção capitalista mantida pela exploração do trabalho e acrescida de elementos "novos" de precarização e flexibilização do trabalho.

9- A discussão do processo de produção capitalista relacionada às formas de produzir de uma determinada sociedade levou inevitavelmente à discussão do momento do consumo, ou seja, às formas de uma sociedade consumir o que foi produzido considerando tal consumo a partir da ótica das relações que o indivíduo, a família e a classe social a qual pertencem estabelecem com outras pessoas, outros grupos e com as instituições do território onde vivem, além das condições de ocupação desse território com suas características geográficas, sociais e ambientais.

Em síntese, considerando-se o referencial da Saúde Coletiva - que tem como objeto os perfis epidemiológicos, compostos por perfis de reprodução social e perfis saúde-doença dos diferentes grupos sociais -, espera-se que a exposição dos elementos de composição do grupo social possibilite prever os desgastes desse grupo e relacioná-los com o processo saúde-doença, para a intervenção sobre os determinantes sociais da saúde. Acredita-se que, dada a composição das variáveis em cada grupo, pode-se supor os tipos de desgaste a que esses grupos estão expostos.

Espera-se também que a aplicação do formulário com o IRS possibilite aos trabalhadores da saúde perceberem a relação entre as condições materiais de existência e o processo saúde-doença da população que atendem. Assim, mesmo que se constitua em instrumento de classificação, acredita-se que os resultados mapeamento dos grupos sociais em um dado território- fundamente um processo de análise e transformação da realidade de saúde

Entretanto, uma limitação deste trabalho diz respeito ao fato de todas as famílias do estudo terem jovens de 15 a 24 anos em sua composição, não sendo estudadas famílias sem jovens já que partiu-se da população do projeto matriz, o que de certa forma dificulta a generalização dos resultados.

Outra limitação é intrínseca à própria epidemiologia. Considera-se que as classes sociais não podem ser definidas apenas por posições estáticas de ocupação ou de posse de bens, mas que as classes se conformam por meio de relações entre si, e 
segundo Marx, nas relações de exploração. Nesse sentido, as classes se constroem em uma dinâmica que é relacional e não só marcada por posições na estrutura econômica, como afirma Thompson. Entretanto, verifica-se que na epidemiologia, ainda não existem métodos para se captar essa dinâmica da relação entre as classes.

Dessa forma, espera-se, ao lançar mão de mecanismos de captação estática da realidade - operacionalizados por meio de variáveis - que a consideração do contexto histórico traga elementos de análise mais dialética, pois não é possível, por exemplo, falar de desgaste no trabalho sem dizer qual é a realidade do trabalhador, a qualificação para ocupação, a situação de formalidade no trabalho.

Assim, as variáveis são capazes de mostrar as diferenças entre os grupos sociais desde que escolhidas a partir de um referencial teórico que possibilite de certa forma captar essa relação, como o da reprodução social. 
10. Referências Bibliográficas 


\section{0- Referências Bibliográficas}

Akerman M. Metodologia de construção de indicadores compostos: um exercício de negociação intersetorial. In: Barata RB, organizadora. Saúde e movimento: condições de vida e situação de saúde. Rio de Janeiro: ABRASCO; 1997.

Almeida E, Villar MEV. Ações públicas para a juventude de Governos locais do Grande ABC: descompassos entre trajetórias. In: Anais da $28^{\mathrm{a}}$ Reunião Anual da ANPEd; 2005 out. 16-19; Minas Gerais, BR [evento na internet]. Caxambu: 2005. Disponível em: http://www.anped.org.br/reunioes/28/inicio.htm

Anderson P. Arguments within English Marxism. Londres: NLB/Verso; 1980

Antunes R. Adeus ao Trabalho? Ensaio sobre as metamorfoses e a centralidade do mundo do trabalho. São Paulo: Cortez; 2000.

Antunes R. Riqueza e miséria do trabalho no Brasil. São Paulo: Boitempo; 2006. A Era da Informatização e a época da informalização: riqueza e miséria do trabalho no Brasil; p. 134-165.

Antunes R. As dimensões da precarização estrutural do trabalho. IN: Druck G, Franco T, oganizadoras. A perda da razão social do trabalho: terceirização e precarização. São Paulo: Boitempo, 2007.

Arouca ASS. O dilema preventivista: contribuição para a compreensão e crítica da medicina preventiva [tese]. Faculdade de Ciências Médicas, Universidade Estadual de Campinas, 1975.

Barban V. Fórum Mundial da água. Revista Espaço de Diálogo e Desconexão. 2009; $1(2): 1-13$.

Barros MBA. A utilização do conceito de classe social nos estudos dos perfis epidemiológicos: uma proposta. Rev. Saúde Pública. 1986; 20(4): 269-73. 
Bava SC. A água é para todos. Instituto Pólis [periódico na Internet]. 2004 dez 1 [citado 2011 ago. 30]. Disponível em: http://www.polis.org.br/artigo_interno.asp?codigo=7.

Bava SC. Privatização da água. Instituto Pólis [periódico na Internet]. 2005 abr 20 [citado 2011 ago. 30]. Disponível em: http://www.polis.org.br/artigo_interno.asp?codigo=94.

Behm H. Economic and social determinants of mortality in Latin America. Rev Cuhana Adm Salud. 1980; 6(1): 1-30.

Bernardo J. Transnacionalização do capital e fragmentação dos trabalhadores. Ainda há lugar para os sindicatos? São Paulo: Boitempo; 2000.

Biagolini REM. Formas de trabalhar e viver maternas e condições de pré-natal (estudo na área de abrangência do Hospital Universitário - Universidade de São Paulo) [dissertação]. São Paulo: Escola de Enfermagem, Universidade de São Paulo; 1999.

Bonduki N, Rolnik R. Periferia da Grande São Paulo. Reprodução do espaço como expediente de reprodução da força de trabalho. In: Maricato E. A produção capitalista da casa (e da cidade) no Brasil industrial. 2. ed. São Paulo: Editora AlfaÔmega; 1982.

Bosma et al. Low job control and risk of Coronary heart disease in the Whilehwall II (prospective cohort) study. American Journal of Public Health. 1997; 86: 332-340

Bourdieu P. A Distinção - crítica social do julgamento. São Paulo: EDUSP; 2008.

Breilh J, Granda E. Investigação da Saúde na Sociedade: guia pedagógico sobre um novo enfoque do método epidemiológico. São Paulo: Cortez; 1989.

Breilh J. Epidemiologia: economia, política e saúde. São Paulo: Ed. Hucitec; 1991.

Brito LC. A ideologia da qualificação, trabalho e a ampliação do "mercado da educação superior". In: Anais do V Colóquio Internacional Marx e Engels; 2007 nov; Campinas, BR [evento na Internet]. Campinas: 2007. [citado 2011 ago. 6]. Disponível em: 
http://www.unicamp.br/cemarx/anais_v_coloquio_arquivos/arquivos/comunicacoes/ gt5/sessao2/Leonardo\%20_Brito.pdf

Bronfman M, Tuirán R. La desigualdad ante La muerte: clases sociales y mortalidad em La niñez. Cuad. méd. soc. 1984; 29/30; 53-75

Campaña A. Em busca da definição de pautas atuais para o delineamento de estudos sobre condições de vida e saúde. In: Barata RB, organizadora. Condições de vida e situação em saúde. Rio de Janeiro: ABRASCO; 1997. p. 142-4.

Carvalheiro JR. Processo Migratório e disseminação de doenças. In: Textos de apoio. Rio de Janeiro: ABRASCO; 1986.

Costa JSD et al. Prevalência de distúrbios psiquiátricos menores na cidade de Pelotas, RS. Rev. Bras. Epidemiol. 2002;5(2):164-75.

Crompton R. Class and stratification. An Introduction to current debates. Cambridge: Polity; 1998.

Donnangelo MCF, Pereira L. Saúde e Sociedade. 2 ed.São Paulo: Duas Cidades; 1979.

Elo IT. Social Class Differentials in Health and Mortality: Patterns and Explanations in Comparative Perspective. Annu. Rev. Sociol. 2009;35:553-72

Frigotto G. Juventude, trabalho e educação no Brasil: perplexidades, desafios e perspectivas. In: Novaes R, Vanucchi P, organizadores. Juventude e sociedade: trabalho, educação, cultura e participação. São Paulo: Fundação Perseu Abramo; 2004.

Galobardes B, Lynch J, Smith GD. Measuring socioeconomic position in health research. British Medical Bulletin. 2007;81-82 (1): 21-37.

Gandarillas MA, Câmara SG, Scarparo H. Estressores sociais da hipertensão em comunidades carentes. Psicologia: Reflexão e crítica. 2005;18 (1): 62-71.

Gianini RJ, Litvoc J, Eluf Neto J. Agressão física e classe social. Rev saúde publica. 1999;33(2):180-6 
Granda E, Breilh J. Investigação da Saúde na Sociedade: guia pedagógico sobre um novo enfoque do método epidemiológico. São Paulo: Cortez; 1991.

Hair JF, Anderson RE, Tatham RL, Black WC. Multivariate data analysis. 5.ed. New Jersey: Prentice Hall;1998.

Instituto Brasileiro de Geografia e Estatística [homepage na internet]. Base de informações por setor censitário: censo demográfico 2000: resultados do universo [citado 2011 jan. 15]. Disponível em: http://www.ibge.gov.br/censo/divulgacao_digital.shtm

Instituto Brasileiro de Geografia e Estatística [homepage na internet]. Estimativas de População 2010 [citado 2010 fev. 23]. Disponível em: http://www.ibge.gov.br/home/estatistica/populacao/estimativa2009/default.shtm

Johnson R, Wichern, D. Applied multivariate statistical analysis. 3 ed. New Jersey: Prentice Hall; 1992.

Knox SS. Perception of social emotional warmth and blood pressure in young men. Perceptual and Motors Skills.1993;77:132-34.

Krantz DS. Effects of psychological and social factors on organic disease: A critical assessmenteof research on coronary heart disease. Annual Review of psichology. 2002; 53: 321-359

Krieger N, Williams DR, Moss NE. Measuring social class in US public health research: concepts, methodologies, and guidelines. Annu. Rev. Public Health. 1997; 18: 341-378.

Lacaz FAC. O sujeito n(d)a Saúde Coletiva e pós-modernismo. Ciênc. Saúde Coletiva. 2001; 6(1):233-42.

Laurell AC. A saúde-doença como processo social. In: Nunes ED, organizador. Medicina Social: aspectos históricos e teóricos. São Paulo: Global; 1983.

Laurell AC, Noriega M. Processo de produção e saúde: trabalho e desgaste operário. São Paulo: Hucitec; 1989. 
Laurell AC. Trabajo y salud: estado del conociemento. In: Franco S, Nunes E, Breilh J, Laurell AC. Debates en Medicina Social. Quito: Organización Panemericana de La Salud; 1991.

Laurenti D. Reprodução Social, prática alimentar e estado nutricional de crianças (estudo populacional no município de Itupeva, SP) [dissertação]. São Paulo: Escola de Enfermagem, Universidade de São Paulo; 2003.

Leite E P. A dupla condenação de prisioneiras na cadeia: um invisível objeto da saúde coletiva [dissertação]. São Paulo: Escola de Enfermagem, Universidade de São Paulo; 1999.

Lombardi C, Bronfman M, Facchini LA et al. Operacionalização do conceito de classes sociais em estudos epidemiológicos. Rev. Saúde Pública. 1988;22(4): 253-65.

Lopes JRB. Brasil, 1989: Um estudo socioeconômico da indigência e da pobreza urbana [monografia na Internet]. Rio de Janeiro: Centro Edelstein de Pesquisas Sociais; 2008 [citado 2010 ago. 22]. Disponível em: http://clinicadotexto.wordpress.com/biblioteca/biblioteca-virtual-de-cienciashumanas/

Marks GN. The Measurement of Socioeconomic Status and Social Class in the LSAY Project Technical Paper No. 14. LSAY Technical Reports [periódico na Internet]. 1999 out 1 [citado 2011 fev. 15]. Disponível em: http://research.acer.edu.au/lsay_technical/28

Marques E, Bichir R, Castello G, Moya ME. Social networks, poverty, and neighborhoods in two brazilians cities [relatório de pesquisa na Internet]. São Paulo: Centro de Estudos da Metrópole, Universidade de São Paulo; 2011. [citado 2011 ago. 30]. Disponível em: http://www.fflch.usp.br/dcp/assets/docs/Eduardo/A01__gotemburgo.pdf

Marx K. O Capital. São Paulo: Nova Cultural; 1996.

Marx K. O 18 Brumário de Luís Bonaparte. São Paulo: Martin Claret; 2008.

Mattar FN. Análise crítica dos estudos de estratificação social sócio econômico de ABA-abipeme. Revista de Administração. 1995;30(1):57-74. 
Mattos MB. Classes sociais e luta de classes: atualidade dos conceitos. In: III Conferencia Internacional La Obra de Carlos Marx y los desafios del Siglo XXI; 2006 mai. 3-6; Havana, CU [evento na Internet]. 2006. [citado 2011 ago. 9]. Disponível em: http://www.nodo50.org/cubasigloXXI/congreso06/conf3_badaro.pdf

Mendes-Gonçalves RB. Investigação epidemiológica e prática médica. In: Costa DC, organizador. Epidemiologia. Teoria e Objeto. São Paulo: Ed. Hucitec; 1990.

Mészáros I. Desemprego e precarização: um grande desafio para a esquerda. In: Antunes R, organizador. Riqueza e miséria do trabalho no Brasil. São Paulo: Boitempo; 2006.

Ministério da Saúde [homepage na Internet]. Programa de Saúde da Família [citado 2011 out. 10]. Disponível em: http://portal.saude.gov.br/portal/saude/cidadao/area.cfm?id_area=149

Ministério do Trabalho e do Emprego [homepage na internet]. Classificação brasileira de Ocupações [citado 2011 jan. 15]. Disponível em: http://www.mtecbo.gov.br/cbosite/pages/pesquisas/BuscaPorCodigo.jsf;jsessionid=B DC0441DC87E232854469E83A17158DC

Nakano K. A busca por cidade justa, democrática e sustentável na metrópole de São Paulo. Nueva Sociedad. 2007;(212):148- 161.

Nettleton S, Burrows R. Mortgage debt, insecure home ownership and health: an exploratory analysis. Sociology of Health \& Ilness. 1998;20(5):731-753.

Nishimura SP, Thomassim LE. Lazer e trabalho na periferia: articulações de possibilidades. In: Anais do IV Congresso Sulbrasileiro de Ciências do Esporte; 2008 set. 19-21; Paraná, BR. p. 912-22.

Office for National Statistics. The National Statistics Socio-economic Classification: User Manual [monografia na Internet]. New York: Palgrave Macmillan; 2005 [citado 2011 jan. 15]. Disponível em: http://www.ons.gov.uk/ons/guidemethod/classifications/archived-standard-classifications/ns-sec/index.html 
Pestana MH, Gajeiro JN. Análise de Dados para Ciências Sociais. 2. ed. Lisboa: Edições Silabo; 2000.

Pochmann M. O trabalho sob fogo cruzado. São Paulo: Contexto; 1999.

Pochmann M, Amorim R. Atlas da Exclusão Social no Brasil. São Paulo: Cortez; 2003.

Pochmann M. Desempregados do Brasil. In: Antunes R organizador. Riqueza e miséria do trabalho no Brasil. São Paulo: Boitempo; 2006; p. 59-73.

Possas C. Epidemiologia e Sociedade. Heterogeinidade estrutural e saúde no Brasil. São Paulo: Hucitec;1989.

Ribeiro MNS. De leprosário a bairro: reprodução social e espaços de segregação na Colônia Antonio Aleixo (Manaus-AM). [tese]. São Paulo: Faculdade de Filosofia, Letras e Ciências Humanas, Universidade de São Paulo, 2011.

Ridenti M. Classes sociais e representação. São Paulo: Cortez; 1994.

Sales-Peres SHC, Bastos JRM. Perfil epidemiológico de cárie dentária em crianças de 12 anos de idade, residentes em cidades fluoretadas e não fluoretadas, na Região Centro-Oeste do Estado de São Paulo, Brasil. Cad. Saúde Pública (FIOCRUZ). 2002;18(5):1281-88

Sallum Jr B. Globalização e estratégia de desenvolvimento: o Brasil nos anos 90. In: Fundap, organizador. Sociedade e Estado - Superando Fronteiras. 1 ed. São Paulo: Fundap; 1998.

Salum MJL, Queiroz VM. Operacionalizando o conceito de coletivo na releitura da categoria Reprodução Social. In: Livro de resumos do V Congresso Brasileiro de Saúde Coletiva e do V Congresso Paulista de Saúde Pública: saúde, responsabilidade do Estado contemporâneo; 1997 ago. 25-29; Águas de Lindóia, BR. Rio de Janeiro: ABRASCO; 1997. p. 18-18.

Salum MJL, Queiroz VM. A construção de perfis epidemiológicos e a responsabilidade da universidade pública na luta pela saúde como direito social. Trabalho apresentado ao Congresso de Medicina Social, $8^{\circ}$ e Congresso da Associação Internacional de Políticas de Saúde, $11^{\circ}$, La Habana, Cuba, 1 - 7 de julho de 2000. 
Santos EV. Para além do desfecho: a violência física doméstica contra o escolar como processo social e como questão da saúde coletiva [tese]. São Paulo: Escola de Enfermagem, Universidade de São Paulo, 1999.

Santos MB. Algumas contribuições ao Projeto Para Viver de Bem com os Bichos (PVBB) enfoque: fauna sinantrópica [tese]. São Paulo: Faculdade de Medicina Veterinária e Zootecnia, Universidade de São Paulo, 2010.

Singer PI. Dominação e desigualdade: estrutura de classes e repartição da renda no Brasil. Rio de Janeiro: Paz e Terra; 1981.

Soares CB, Ávila LK, Salvetti MG. Necessidades (de saúde) de adolescentes do D. A. Raposo Tavares, SP, referidas à família, à escola e bairro. Revista Brasileira de Crescimento e Desenvolvimento Humano. 2000;10(2):19-34.

Soares CB, Salvetti MG, Ávila LK. Opinião de escolares e educadores sobre saúde: o ponto de vista da escola pública de uma região periférica do Município de São Paulo. Cad. Saúde Pública FIOCRUZ. 2003;19(4):1153-61.

Soares CB. Consumo contemporâneo de drogas e juventude: a construção do objeto na perspectiva da saúde coletiva [tese de livre-docência]. São Paulo: Escola de Enfermagem, Universidade de São Paulo; 2007.

Solla JJSP. Classe social e saúde: um estudo sobre a utilização deste conceito na investigação epidemiológica [dissertação]. Salvador: Universidade Federal da Bahia; 1992.

Solla JJSP. Diferenças nas propostas de operacionalização do conceito de classe social empregadas em estudos epidemiológicos. Cad. Saúde Pública FIOCRUZ. 1996;12(3): 329-37.

Sorj B, Martucelli D. O desafio latino-americano: coesão social e democracia. Rio de Janeiro: Civilização Brasileira; 2008.

Souza JS. Os descaminhos das políticas de formação/qualificação profissional: a ação dos sindicatos no Brasil recente. In: Antunes R, organizador. Riqueza e miséria do trabalho no Brasil. São Paulo: Boitempo; 2006.

Souza J, organizador. Os batalhadores brasileiros: nova classe média ou nova classe trabalhadora? Belo Horizonte: Editora UFMG, 2010. 
SPSS Statistics [computer program]. Version 17.0. Chicago (IL): SPSS Inc; 2004.

Tamami AM. Problemas respiratórios em crianças menores de dois anos e a reprodução social das famílias. Estudo populacional no Município de Itupeva, SP [tese]. São Paulo: Escola de Enfermagem, Universidade de São Paulo, 2007.

Teixeira F. Marx, ontem e hoje. In: Teixeira F, Frederico C. Marx no século XXI. São Paulo: Cortez Editora, 2009.

Thiollent M. Crítica metodológica, investigação social e enquete operária. São Paulo: Polis; 1987.

Thompson EP. A formação da classe operária inglesa. Paz e Terra: São Paulo; 1987.

Vasapollo L. O trabalho atípico e a precariedade: elemento estratégico determinante do capital no paradigma pós-fordista. In: Antunes R, organizador. Riqueza e miséria do trabalho no Brasil. São Paulo: Boitempo; 2006.

Viana N. A consciência da história. Ensaios sobre o materialismo histórico-dialético. Rio de Janeiro: Achiamé; 2007.

Viana N. O capitalismo na era da acumulação integral. Aparecida, SP: Santuário; 2009.

Weber M. Economia e Sociedade - Fundamentos da Sociologia Compreensiva. Brasília: Editora UNB; 1999. v. 2.

Wright EO. Class, crisis, and the state. Pennsylvania: NLB; 1978.

Wright EO. The Debate on Classes. London: Verso; 1989.

Wright EO. Class counts. Comparative studies in class analysis. Cambridge: Cambridge University Press; 1997. 
Yonekura T, Soares CB, Minuci EG, Campos CMS, Trapé CA. Mapa das Juventudes de Santo André, SP: instrumento de leitura das desigualdades sociais. Revista de Saúde Pública. 2010;44(1): 45-52.

Yonekura T. A Operacionalização do conceito de classe na epidemiologia: uma revisão sistemática. [dissertação]. São Paulo: Escola de Enfermagem, Universidade de São Paulo; 2011. 
ANEXOS 
ANEXO I 
ANEXO II 


\title{
ANEXO II \\ MANUAL DE PREENCHIMENTO
}

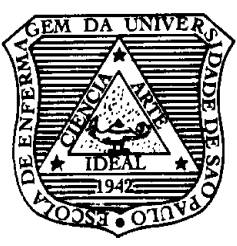

\author{
UNIVERSIDADE DE SÃO PAULO \\ ESCOLA DE ENFERMAGEM \\ DEPARTAMENTO DE ENFERMAGEM \\ EM SAÚDE COLETIVA
}

Av.Dr. Enéas de Carvalho Aguiar, 419 - CEP 05403-000

Tel.: (011) 3061-7652 - FAX 3061-7662

Pesquisa: Jovens, valores e consumo de drogas: políticas públicas na perspectiva da Saúde Coletiva

\section{ORIENTACÕES PARA O PREENCHIMENTO DO FORMULÁRIO}

\section{A) GERAIS}

- Este é um formulário de coleta de dados relativos à identificação e formas de trabalhar e de viver das famílias dos jovens que farão parte da pesquisa. Está associado a uma entrevista ou grupo focal, a depender da idade do jovem a que se refere. O grupo ou entrevista individual coletará dados qualitativos relacionados a valores sociais dos jovens. O jovem entre 15 e 19 anos de idade participará de um grupo focal, sendo que um responsável por ele assinará o termo de consentimento livre e esclarecido e em seguida responderá a este questionário. Nesse caso, anotar na PRIMEIRA página do questionário: o nome correspondente ao grupo focal do qual participou e o nome da escola a qual pertence. Já os jovens de 20 a 24 passarão por uma entrevista, e poderão eles mesmos responder a este questionário. Nesse caso, deve ser anotado no verso o nome do jovem, sua idade e a escola ou instituição contatada.

- Normalmente, a coleta de dados será feita nos locais onde os jovens estudam ou trabalham, a depender do arranjo feito com a escola ou outra instituição contatada, mas pode haver casos em que se terá que ir até o domicílio.

- Antes de terminar de preencher o formulário, confira se todos os campos estão devidamente preenchidos e com a pré-codificação correta.

- Algumas vezes, o entrevistado será questionado sobre as pessoas que moram em sua casa e ele não saberá informar. Anote o número do código correspondente ao NÃO SABE (99), quando for o caso.

- Há questões, cujas opções de resposta, listadas no rodapé, não se aplicam (por exemplo, informações sobre o trabalho quando a pessoa não trabalha fora); Anote o número do código correspondente ao NÃO SE APLICA (98), quando for o caso.

- Quando houver opções de respostas listadas no rodapé, mencionar as alternativas UMA A UMA, para o entrevistado escolher a(s) que se aplica (m).

- Preencher o questionário A TINTA, evitando rasuras; nesse caso, riscar e anotar a informação correta, ou no rodapé, ou no verso da folha.

- O espaço no verso das páginas do formulário foi deixado em branco para anotações, quando for o caso. Se esse for o caso, certifique-se de que as anotações estejam claras para que o digitador tenha certeza de relacionar a informação ao item 
adequado.CASO TENHA DÚVIDAS SOBRE O PREENCHIMENTO, ANOTAR AS INFORMAÇÕES DA FORMA MAIS COMPLETA POSSÍVEL PARA POSTERIOR DISCUSSÃO COM SUPERVISOR.

- Em caso de impedimento, pelo entrevistado, de iniciar ou prosseguir com a entrevista, agradecer a colaboração.

- É importante pactuar com o entrevistado que talvez haja necessidade de realizar contatos telefônicos posteriores com a finalidade de esclarecer possíveis dúvidas a respeito do preenchimento do instrumento.

- RECOLHER A ASSINATURA NA FOLHA DE CONSENTIMENTO ESCLARECIDO ANTES DE INICIAR A ENTREVISTA E DEIXAR UMA CÓPIA COM O ENTREVISTADO.

\section{B) ESPECÍFICAS}

\section{IDENTIFICAÇÃO GERAL: (p.1)}

- No formulário: NÃO PREENCHER, pois será atribuído um número de ordem no momento da alimentação do banco de dados;

- Nome do entrevistado: anotar somente o nome e a sua Relação com o Chefe;

- Endereço: anotar o endereço COMPLETO, incluindo rua, número da habitação, bairro; e CEP. O número do CEP, com oito dígitos, poderá ser perguntado para o entrevistado, caso ele não saiba, será preenchido após consulta na lista de CEP.

\section{PÁGINA 1}

- Prenome e qual a relação com o chefe. PERGUNTAR QUANTAS FAMÍliaS MORAM NO DOMICÍlIO E QUAL É A FAMÍlIA PRINCIPAL. Use o número do código correspondente: o primeiro membro a ser registrado sempre corresponderá ao Chefe da família principal, cujo número de código é 1. Seguir a ordem de preenchimento dos números de código correspondentes aos da esposa ou marido, filhos e agregados, de acordo com a tabela de codificação. Se o domicílio tiver mais de uma família, iniciar a Segunda por 111, 112, etc, a terceira por 211, 212 e assim sucessivamente.

- Sexo: use o $\mathrm{N}^{\mathrm{o}}$ código correspondente para masculino (1) ou feminino (2), uma vez que pelo prenome nem sempre se pode supor o sexo.

- Religião: Especificar a religião do entrevistado e o culto que freqüenta. O entrevistado pode se auto-denominar católico, mas freqüentar cultos evangélicos ou de outra religião. Religião afrobrasileira diz respeito a umbanda, candomblé, entre outros. Religiões orientais dizem respeito a budismo, seicho-no-ie, entre outros.

- Idade: Colocar a idade em anos completos. Se o morador tiver menos de 1 ano colocar a idade em meses e registrar "meses". Se o entrevistado não souber a idade dos outros moradores assinalar 99 (não sabe).

- Cor/Raça/Etnia: Colocar o código da cor auto-referida pelo entrevistado. Para fins de comparação com o IBGE temos apenas as opções propostas no instrumento. Se o entrevistado insistir e não se classificar anotar o que ele considera (por exemplo, anotar "moreno" se ele assim referir). 
- Local de nascimento: região do país em que nasceu. Caso tenha nascido em São Paulo definir se na região metropolitana ou no interior ou em Santo André ou no grande ABC excluindo Santo André.

- Escolaridade: Perguntar até que ano da escola completou com aprovação: F. INCOMPLETO $=$ FUNDAMENTAL INCOMPLETO - até a $7^{a}$ série concluída; $F$. COMPLETO = FUNDAMENTAL COMPLETO $-8^{\mathrm{a}}$ série concluída; M. COMPLETO $=$ MÉDIO COMPLETO $3^{\circ}$ colegial/escola normal/magistério concluídos; S. COMPLETO = SUPERIOR COMPLETO - Nível Universitário concluído. SUPL. $\mathrm{EF}=$ SUPLETIVO FUNDAMENTAL e SUPL. EM = SUPLETIVO ENSINO MÉDIO preencher caso tenham sido completados. (Classificação da LDB). PÓS GRAD.= PÓS GRADUAÇÃO

- Condição de atividade: Perguntar se está trabalhando no momento: anotar o número do código correspondente. Trabalhador familiar: diz respeito ao sujeito que trabalha em alguma atividade da família e recebe algum tipo de remuneração do familiar (entrega as marmitas produzidas pelo familiar, recebe por pequenos consertos em roupas, entre outras). Autônomo: é aquele que trabalha por conta própria em atividade relativamente estável, diferente do bico que se caracteriza por atividades esporádicas de diferentes características. Pensionista: recebe algum tipo de pensão como a proveniente do governo, divórcio ou morte do cônjuge. Empregador: possui pelo menos um empregado. Nos casos de afastamento do trabalho por motivo de saúde, por exemplo, considerar trabalhador assalariado. Em caso de ser pensionista (6) anotar o valor da pensão. Caso a pessoa seja aposentada e pensionista registrar (1) e (6). Não inserido diz respeito aos maiores de 14 anos que poderiam estar trabalhando por lei. No caso dos menores de 14 anos deverá se registrar não se aplica, pois, esses não poderiam estar trabalhando.

- Benefício advindo de programas redistributivos ou de instituições da sociedade civil: podem ser assinalados até 3 tipos de benefícios. Se não encontrar o benefício na listagem fornecida no questionário, utilizar outros e especificar nas linhas fornecidas logo abaixo do código. Registrar os valores de cada um dos benefícios, caso se aplique. Se o benefício for dirigido para toda a família como a bolsa família, por exemplo, registrar como beneficiário apenas o membro inscrito no programa.

- Quanto tempo gasta para ir/voltar do trabalho/escola? Anotar o tempo total em minutos. Para cada trabalhador, anotar o número de identificação e o tempo gasto na linha ao lado. No caso não se aplica, preencher com zero (0) o campo correspondente.

\section{PÁGINA 2}

\footnotetext{
Perguntas sobre as pessoas da família que trabalham, mesmo que estejam desempregadas no momento (não esquecer de incluir também os aposentados, estagiários e bolsistas): seguir a ordem de preenchimento dos números de código correspondentes aos dados da esposa ou marido, filhos e agregados, de acordo com a codificação, como foi feito no campo da folha de identificação.
} 
- Profissão: preencher com a informação a respeito da profissão original para a qual o entrevistado se preparou para exercer. Se estiver trabalhando, mas não tiver uma profissão, caso do estudante que trabalha, por exemplo, preencher estudante no campo profissão.

Ocupação/função: Descrever a ocupação do entrevistado ou membro da família. Independe muitas vezes da profissão. O indivíduo pode ter se formado em administração de empresas (profissão) e estar trabalhando com telemarketing (ocupação). Detalhar ao máximo a ocupação. Por exemplo: guardador de carros fixo toda noite ou guardador de carros em uma rua quando ocorrem eventos. O primeiro possui muito mais estabilidade que o segundo. Atenção também ao caso de estudantes que ainda não tem uma profissão, mas estão trabalhando em ocupações diversas, por exemplo, como vendedor em loja de roupas, entre outras. Se o estudante estiver trabalhando como estagiário, especificar a área do estágio, por exemplo, estagiário de informática. Se o membro da família for aposentado, assinalar não se aplica.

No caso da pessoa ter dois trabalhos, considerar o principal que é definido pelo IBGE da seguinte forma:

\section{Trabalho Principal da Semana de Referência- o único trabalho que a pessoa teve} nesse período.

Para a pessoa que tem mais de um trabalho, ou seja, para a pessoa ocupada em mais de um empreendimento na semana de referência, adotam-se os seguintes critérios, obedecendo a ordem enumerada, para definir o principal desse período:

$\left.1^{\circ}\right)$ O trabalho da semana de referência, no qual teve maior tempo de permanência, no período de referência de 365 dias, foi considerado como principal;

$\left.2^{\circ}\right)$ Em caso de igualdade no tempo de permanência, no período de referência de 365 dias, considerou-se como principal o trabalho remunerado da semana de referência ao qual a pessoa normalmente dedicava maior número de horas semanais. Este mesmo critério foi adotado para definir o trabalho principal da pessoa que, na semana de referência, teve somente trabalhos não-remunerados e que apresentaram o mesmo tempo de permanência no período de referência de 365 dias; $e$

$\left.3^{\circ}\right)$ Em caso de igualdade, também, no número de horas trabalhadas, considerou-se como principal o trabalho da semana de referência que normalmente proporcionava maior rendimento.

- Setor de trabalho: público, privado ou misto. Considerar natureza da instituição. Assinalar não se aplica no caso dos aposentados.

- Onde trabalha: local em que realiza a atividade, por exemplo, o nome da empresa ou da instituição. No caso de guardador de carros considerar a rua como local e no caso da doméstica considerar a casa da patroa. Considerar não se aplica no caso dos aposentados. 
- Horas semanais trabalhadas: Média avaliada pelo informante (ajudar o informante a fazer as contas, se necessário). Assinalar não se aplica no caso dos aposentados.

\section{PÁGINA 3}

\section{Repetir a ordem de identificação dos trabalhadores feita na página 2.}

- Tem registro em carteira: o número de código correspondente à codificação não se aplica (98) diz respeito a militares e estatutários, pois estes não são registrados. A categoria dos militares e funcionários públicos estatutários é constituída pelos militares do Exército, Marinha de Guerra e Aeronáutica, inclusive as pessoas que prestam o serviço militar obrigatório, e pelos empregados regidos pelo Estatuto dos Funcionários Públicos (federais, estaduais e municipais ou de autarquias). No caso de aposentados ou bolsistas, usar também não se aplica (98).

Fez algum curso que preparasse para o trabalho? Considerar cursos de especialização, atualização, curso técnico ou outro de natureza profissionalizante que preparou o trabalhador para o trabalho que exerce atualmente

Tempo de trabalho: Assinalar o tempo de trabalho em anos ou meses caso o trabalhador esteja no mesmo emprego há menos de 1 ano.

- Renda no trabalho principal: Anotar o salário líquido do último mês (anterior a data da pesquisa) em reais; se houver dúvida, ofereça opções de faixas tipo até 100 reais, de 100 a 200 reais, etc; lembre-se que os aposentados também têm renda.

- Rendas adicionais: Caso o entrevistado ou membro da família receba, registrar até dois tipos de rendas adicionais segundo a codificação. Auxílio INSS refere-se ao trabalhador afastado por doença ou acidente (nesse caso, não estará recebendo a renda principal).Caso o membro da família não possua nenhuma renda adicional, preencher com zero (0), o campo correspondente.

Recebe algum benefício oriundo do trabalho: anotar até 3 tipos de benefícios que recebe segundo a codificação. Considerar os mais significativos em termos de contribuição para a renda. Atentar para o caso em que o esposo tem convênio médico e ele inclui a esposa e os filhos. Na verdade o benefício é só dele e não dos demais membros, pois se perder o emprego, perde o benefício também.

PÁGINA 4 (dirigido para a Família). 
- Material predominante na habitação: Se for ao domicílio, observe o tipo de material que predomina na construção da habitação e escolha a alternativa. Do contrário, pergunte se a casa é de alvenaria, se tem acabamento, se é de madeira ou de material aproveitado (papelão, plástico).

- Localização - Perguntar e assinalar a alternativa que caracterize o local da habitação:

1. Favela - conjunto de unidades habitacionais em terreno alheio público ou particular dispostos, em geral, de forma desordenada e, na maioria dos casos, carente de serviços essenciais, como saneamento, coleta de lixo, escolas ou postos de saúde. 2. Cortiço - Habitação Precária Coletiva de Aluguel. 3. Casa ou apartamento - casa: quando localizada em uma edificação de um ou mais pavimentos, desde que ocupado integralmente por um único domicílio, com acesso direto a um logradouro, legalizado ou não, independente do material utilizado em sua construção; apartamento - quando localizado em edifício de um ou mais andares, com mais de um domicílio, servido por espaços comuns (hall de entrada, escadas, corredores, portaria ou outras dependências).

4. Conjunto habitacional popular (CDHU, COHAB, etc) - conjunto de unidades habitacionais populares com características semelhantes construído a partir de recursos federais, estaduais ou municipais; 5- Quintal comum- domicílio que divide o quintal com outras moradias

- Propriedade da residência: registrar o código correspondente. Própria regular: diz respeito às situações em que os moradores possuem a escritura ou o contrato de compra e venda ou ainda o direito de morar por uso capião.

- Paga IPTU?- registrar o código correspondente.

- Tempo de moradia: tempo em que a família mora no domicílio atual em anos: registrar 0 (zero) se for menos de 1 ano e anotar o número de anos, se for um ou mais, desprezando as frações de ano; se o entrevistado não souber informar, registre o número do código correspondente.

- Motivo da mudança: Anotar o motivo da mudança do domicílio se ela ocorreu a menos de 5 anos. Piora das condições financeiras pode estar relacionado à dificuldade de pagar o aluguel ou prestação da casa. Melhora de infraestrutura diz respeito ao caso em que não houve melhora das condições financeiras, mas mesmo assim a família procurou uma moradia melhor. Não se aplica diz respeito aos casos em que a família se mudou há mais de 5 anos ou nunca se mudou.

- Bens no domicílio (em quantidade): marcar quantos; se não houver, colocar zero (0). Em relação aos empregados mensalistas considerar empregadas domésticas, jardineiros, motoristas, entre outros. No que diz respeito à internet, se os membros tiverem acesso, preencher a quantidade com o número 1. Em relação ao número de cômodos para dormir, se considera o espaço com quatro paredes de qualquer material (não se considera a divisão por lençóis ou armários como dois cômodos).

- Acesso aos serviços públicos - Água/Luz/Lixo: registrar o código correspondente em cada item. 
- Recebe conta desses serviços: Água/Luz: registrar o código correspondente em cada item caso a pessoa afirmar que recebe conta desses serviços. No caso do esgoto colocar no campo a especificação sobre o destino.

- Forma de coleta de lixo - Anotar no campo a alternativa correspondente.

\section{PÁGINA 5}

- Risco a que as pessoas da casa se sentem mais expostas: registrar no campo o código do risco a que o entrevistado se sente exposto. Assinalar sim (1) ou não (2) para cada um.

- Instituições que utiliza: registrar no campo o código correspondente segundo o tipo de instituição podendo assinalar até três instituições. Em relação à igreja considerar participação em atividades não relacionadas a cultos ou missas. Se ninguém da família utiliza nenhuma instituição, assinalar zero nos campos

- Participação de grupo/associação/sindicato/partido político -a família ou algum de seus membros participa de algum grupo/associação/sindicato- registrar até três opções no campo.

- Qual o meio de transporte que utiliza normalmente para ir ao local de trabalho: Assinalar sim (1) ou não (2) para cada um.

- Lazer: um membro da família se dedicando a alguma forma de lazer já é suficiente para preencher os campos. Assinalar sim (1) ou não (2) para cada uma das opções. Ler cada uma das opções para os entrevistados. Atividade física diz respeito tanto a esportes como futebol, natação, basquete como atividades de dança, capoeira, etc. Visitas incluem visitas a familiares e/ou amigos. Outros podem incluir jogos de tabuleiro como xadrez, dominós, etc

PÁGINA 6

- Para arcar com os gastos de alimentação, vestuário, água e luz, a renda da família é:- Anotar a alternativa correspondente segundo o relato do entrevistado.

- Algum membro da família possui poupança ou outras aplicações? Marcar uma das alternativas: sim (1), não (2) ou não sabe (99).

- Tem gastos com crediários/ empréstimos? Marcar uma das alternativas: sim (1), não (2) ou não sabe (99).

- Está com o nome no Serasa ou tem dívidas que não consegue pagar?Marcar uma das alternativas: sim (1), não (2) ou não sabe. 


\section{ANEXO III MAPA DAS JUVENTIDES DE SANTO ANDRÉ}

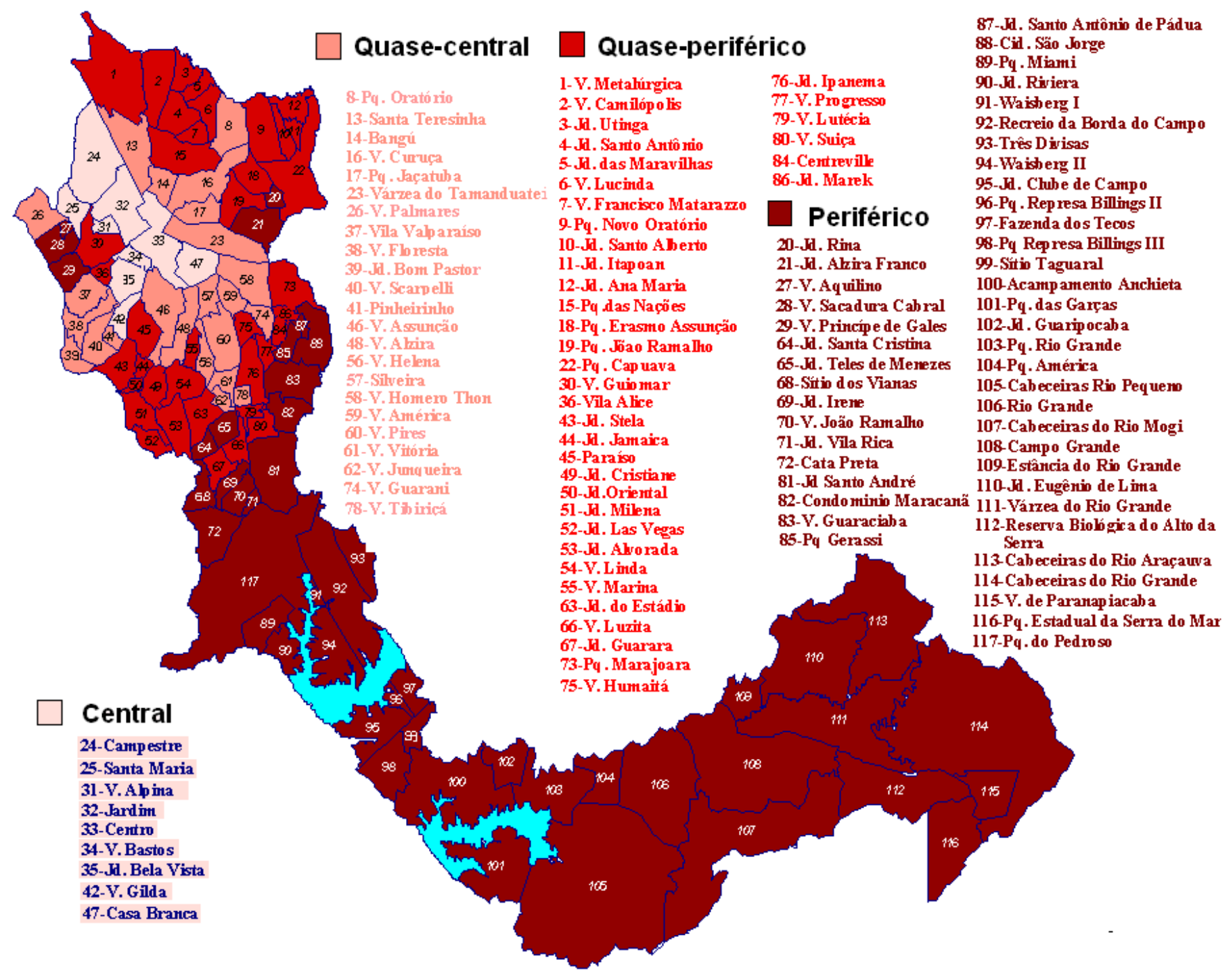


ANEXO IV 


\section{ANEXO IV- COMPORTAMENTO DAS VARIÁVEIS NOS QUATRO GRUPOS SOCIAIS ORIGINAIS}

Os dados apresentados a seguir dizem respeito às famílias dos jovens distribuídas nos quatro grupos sociais originais segundo local de moradia das famílias.

\section{Caracterização sócio-demográfica}

Em relação aos dados sócio-demográficos verificou-se que a distribuição de homens e mulheres se equiparou nos quatro grupos (tabela 1) não havendo diferença significativa $(\mathrm{p}=0,418)$. Entretanto, quanto ao sexo dos chefes de famílias verifica-se que o número de famílias chefiadas por mulheres vai aumentando nos grupos mais excluídos, demonstrando que chefia feminina se configura em variável importante para discriminar os grupos sociais $(\mathrm{p}=0,006)$ (tabela 2$)$.

No que diz respeito à faixa etária observa-se por meio da tabela 3 que nos grupos central, quase central e quase periférico os indivíduos se concentram nas faixas etárias de 15 a 19 anos e de 45 a 44 anos. Entretanto, no grupo periférico os indivíduos de distribuem de forma mais equiitativa nas diversas faixas ressaltando que nesse grupo há uma maior concentração de indivíduos com menos de 15 anos.

Quanto à raça, a branca foi preponderante nos quatro grupos sendo que nos grupos mais excluídos houve uma concentração maior de pardos principalmente no periférico (tabela 4).

A maior parte dos indivíduos dos grupos quase central, quase periférica e periférica nasceu em Santo André. Já os indivíduos do grupo central se distribuíram de forma mais eqüitativa entre região metropolitana de São Paulo, Santo André e outras cidades do Grande ABC (tabela 5).

Tabela 1 - Distribuição dos indivíduos dos quatro grupos sociais segundo sexo. Santo André, SP, 2008.

\begin{tabular}{|c|c|c|c|c|c|c|c|c|c|c|}
\hline \multirow[b]{3}{*}{ Sexo } & \multicolumn{8}{|c|}{ GRUPO SOCIAL } & \multirow{2}{*}{\multicolumn{2}{|c|}{ Total }} \\
\hline & \multicolumn{2}{|c|}{ Central } & \multicolumn{2}{|c|}{ Quase Central } & \multicolumn{2}{|c|}{ Quase Periférico } & \multicolumn{2}{|c|}{ Periférico } & & \\
\hline & $\mathbf{N}$ & $\%$ & $\mathbf{N}$ & $\%$ & $\mathbf{N}$ & $\%$ & $\mathbf{N}$ & $\%$ & $\mathbf{N}$ & $\%$ \\
\hline Masculino & 51 & 50,00 & 190 & 50,53 & 503 & 48,83 & 440 & 46,07 & 1184 & 48,07 \\
\hline Feminino & 51 & 50,00 & 186 & 49,47 & 527 & 51,17 & 515 & 53,93 & 1279 & 51,93 \\
\hline Total & 102 & 100,00 & 376 & 100,00 & 1030 & 100,00 & 955 & 100,00 & 2463 & 100,00 \\
\hline
\end{tabular}


Tabela 2 - Distribuição dos indivíduos dos quatro grupos sociais segundo sexo do chefe de família. Santo André, SP, 2008.

\begin{tabular}{|c|c|c|c|c|c|c|c|c|c|c|}
\hline \multirow[b]{3}{*}{$\begin{array}{l}\text { Sexo chefe } \\
\text { de família }\end{array}$} & \multicolumn{8}{|c|}{ GRUPO SOCIAL } & \multirow{2}{*}{\multicolumn{2}{|c|}{ Total }} \\
\hline & \multicolumn{2}{|c|}{ Central } & \multicolumn{2}{|c|}{ Quase Central } & \multicolumn{2}{|c|}{ Quase Periférico } & \multicolumn{2}{|c|}{ Periférico } & & \\
\hline & $\mathbf{N}$ & $\%$ & $\mathbf{N}$ & $\%$ & $\mathbf{N}$ & $\%$ & $\mathbf{N}$ & $\%$ & $\mathbf{N}$ & $\%$ \\
\hline Masculino & 20 & 76,92 & 71 & 83,53 & 191 & 76,71 & 151 & 65,94 & 433 & 73,51 \\
\hline Feminino & 6 & 23,08 & 14 & 16,47 & 58 & 23,29 & 78 & 34,06 & 156 & 26,49 \\
\hline Total & 26 & 100,00 & 85 & 100,00 & 249 & 100,00 & 229 & 100,00 & 589 & 100,00 \\
\hline
\end{tabular}

Tabela 3 - Distribuição dos indivíduos dos quatro grupos sociais segundo faixa etária. Santo André, SP, 2008.

\begin{tabular}{|c|c|c|c|c|c|c|c|c|c|c|}
\hline \multirow[b]{3}{*}{ Faixa Etária } & \multicolumn{8}{|c|}{ GRUPO SOCIAL } & \multirow{2}{*}{\multicolumn{2}{|c|}{ Total }} \\
\hline & \multicolumn{2}{|c|}{ Central } & \multicolumn{2}{|c|}{ Quase Central } & \multicolumn{2}{|c|}{ Quase Periférico } & \multicolumn{2}{|c|}{ Periférico } & & \\
\hline & $\mathbf{N}$ & $\%$ & $\mathbf{N}$ & $\%$ & $\mathbf{N}$ & $\%$ & $\mathbf{N}$ & $\%$ & $\mathbf{N}$ & $\%$ \\
\hline Menor de 14 & 11 & 10,78 & 54 & 14,36 & 122 & 11,84 & 190 & 19,90 & 377 & 15,31 \\
\hline 15 a 19 & 27 & 26,47 & 70 & 18,62 & 225 & 21,84 & 214 & 22,41 & 536 & 21,76 \\
\hline 20 a 24 & 12 & 11,76 & 63 & 16,76 & 171 & 16,60 & 145 & 15,18 & 391 & 15,87 \\
\hline 25 a 34 & 3 & 2,94 & 26 & 6,91 & 87 & 8,45 & 74 & 7,75 & 190 & 7,71 \\
\hline 35 a 44 & 14 & 13,73 & 56 & 14,89 & 137 & 13,30 & 156 & 16,34 & 363 & 14,74 \\
\hline 45 a 54 & 28 & 27,45 & 78 & 20,74 & 206 & 20,00 & 131 & 13,72 & 443 & 17,99 \\
\hline 55 e mais & 7 & 6,86 & 29 & 7,71 & 82 & 7,96 & 45 & 4,71 & 163 & 6,62 \\
\hline Total & 102 & 100,00 & 376 & 100,00 & 1030 & 100,00 & 955 & 100,00 & 2463 & 100,00 \\
\hline
\end{tabular}

Tabela 4 - Distribuição dos indivíduos dos quatro grupos sociais segundo raça.

Santo André, SP, 2008.

\begin{tabular}{|c|c|c|c|c|c|c|c|c|c|c|}
\hline \multirow[b]{3}{*}{ Raça } & \multicolumn{8}{|c|}{ GRUPO SOCIAL } & \multirow{2}{*}{\multicolumn{2}{|c|}{ Total }} \\
\hline & \multicolumn{2}{|c|}{ Central } & \multicolumn{2}{|c|}{ Quase Central } & \multicolumn{2}{|c|}{ Quase Periférico } & \multicolumn{2}{|c|}{ Periférico } & & \\
\hline & $\mathbf{N}$ & $\%$ & $\mathbf{N}$ & $\%$ & $\mathbf{N}$ & $\%$ & $\mathbf{N}$ & $\%$ & $\mathbf{N}$ & $\%$ \\
\hline Preta & 4 & 3,92 & 26 & 6,91 & 102 & 9,90 & 135 & 14,14 & 267 & 10,84 \\
\hline Parda & 10 & 9,80 & 70 & 18,62 & 302 & 29,32 & 324 & 33,93 & 706 & 28,66 \\
\hline Branca & 88 & 86,27 & 279 & 74,20 & 604 & 58,64 & 481 & 50,37 & 1452 & 58,95 \\
\hline Amarela & 0 & 0,00 & 0 & 0,00 & 18 & 1,75 & 2 & 0,21 & 20 & 0,81 \\
\hline Indígena & 0 & 0,00 & 0 & 0,00 & 4 & 0,39 & 13 & 1,36 & 17 & 0,69 \\
\hline SI & 0 & 0,00 & 1 & 0,27 & 0 & 0,00 & 0 & 0,00 & 1 & 0,04 \\
\hline Total & 102 & 100,00 & 376 & 100,00 & 1030 & 100,00 & 955 & 100,00 & 2463 & 100,00 \\
\hline
\end{tabular}


Tabela 5 - Distribuição dos indivíduos dos quatro grupos sociais segundo local de nascimento. Santo André, SP, 2008.

\begin{tabular}{|c|c|c|c|c|c|c|c|c|c|c|}
\hline \multirow[b]{3}{*}{ Nascimento } & \multicolumn{8}{|c|}{ GRUPO SOCIAL } & \multirow{2}{*}{\multicolumn{2}{|c|}{ Total }} \\
\hline & \multicolumn{2}{|c|}{ Central } & \multicolumn{2}{|c|}{ Quase Central } & \multicolumn{2}{|c|}{ Quase Periférico } & \multicolumn{2}{|c|}{ Periférico } & & \\
\hline & $\mathbf{N}$ & $\%$ & $\mathbf{N}$ & $\%$ & $\mathbf{N}$ & $\%$ & $\mathbf{N}$ & $\%$ & $\mathbf{N}$ & $\%$ \\
\hline RMSP & 28 & 27,45 & 45 & 11,97 & 100 & 9,71 & 84 & 8,80 & 257 & 10,43 \\
\hline SP Interior & 9 & 8,82 & 38 & 10,11 & 108 & 10,49 & 54 & 5,65 & 209 & 8,49 \\
\hline Santo André & 29 & 28,43 & 168 & 44,68 & 445 & 43,20 & 394 & 41,26 & 1036 & 42,06 \\
\hline $\begin{array}{l}\text { Grande } \mathrm{ABC} \\
\text { exceto Santo }\end{array}$ & 26 & 25,49 & 51 & 13,56 & 132 & 12,82 & 114 & 11,94 & 323 & 13,11 \\
\hline André & & & & & & & & & & \\
\hline Sudeste & 7 & 6,86 & 19 & 5,05 & 49 & 4,76 & 25 & 2,62 & 100 & 4,06 \\
\hline Sul & 0 & 0,00 & 4 & 1,06 & 31 & 3,01 & 44 & 4,61 & 79 & 3,21 \\
\hline Nordeste & 2 & 1,96 & 37 & 9,84 & 139 & 13,50 & 173 & 18,12 & 351 & 14,25 \\
\hline Norte & 0 & 0,00 & 1 & 0,27 & 13 & 1,26 & 32 & 3,35 & 46 & 1,87 \\
\hline Centro Oeste & 0 & 0,00 & 3 & 0,80 & 6 & 0,58 & 15 & 1,57 & 24 & 0,97 \\
\hline Outro país & 1 & 0,98 & 0 & 0,00 & 4 & 0,39 & 1 & 0,10 & 6 & 0,24 \\
\hline Não sabe & 0 & 0,00 & 10 & 2,66 & 3 & 0,03 & 19 & 1,99 & 32 & 1,30 \\
\hline Total & 102 & 100,00 & 376 & 100,00 & 1030 & 100,00 & 955 & 100,00 & 2463 & 100,00 \\
\hline
\end{tabular}

Quanto à religião (tabela 6) verificou-se que a maior parte dos indivíduos dos quatro grupos é católica. Ressalta-se que no grupo central há uma maior concentração de espíritas e de indivíduos que referem não ter religião. Por outro lado os pentecostais se concentram no grupo periférico. Quando se verificou qual era o culto ou religião efetivamente praticada (tabela 7) observou-se que quase metade dos integrantes dos grupos central e quase central não eram praticantes. $\mathrm{O}$ mesmo não ocorreu nos grupos quase periférico e periférico em que houve uma distribuição mais equitativa entre indivíduos não praticantes e os que freqüentam missas (católicos) e cultos (pentecostais). 
Tabela 6 - Distribuição dos indivíduos dos quatro grupos sociais segundo religião.

Santo André, SP, 2008.

\begin{tabular}{|c|c|c|c|c|c|c|c|c|c|c|}
\hline \multirow[b]{3}{*}{ Religião } & \multicolumn{8}{|c|}{ GRUPO SOCIAL } & \multirow{2}{*}{\multicolumn{2}{|c|}{ Total }} \\
\hline & \multicolumn{2}{|c|}{ Central } & \multicolumn{2}{|c|}{ Quase Central } & \multicolumn{2}{|c|}{ Quase Periférico } & \multicolumn{2}{|c|}{ Periférico } & & \\
\hline & $\mathbf{N}$ & $\%$ & $\mathbf{N}$ & $\%$ & $\mathbf{N}$ & $\%$ & $\mathbf{N}$ & $\%$ & \multicolumn{2}{|c|}{$\mathbf{N}^{\text {Total }} \%$} \\
\hline Católica & 51 & 50,00 & 213 & 56,65 & 592 & 57,48 & 473 & 49,53 & 1329 & 53,96 \\
\hline Test. de Jeová & 0 & 0,00 & 9 & 2,39 & 20 & 1,94 & 17 & 1,78 & 46 & 1,87 \\
\hline Histórico & 5 & 4,90 & 5 & 1,33 & 23 & 2,23 & 23 & 2,41 & 56 & 2,27 \\
\hline Pentecostal & 4 & 3,92 & 85 & 22,61 & 225 & 21,84 & 260 & 27,23 & 574 & 23,30 \\
\hline Espírita & 17 & 16,67 & 12 & 3,19 & 21 & 2,04 & 26 & 2,72 & 76 & 3,09 \\
\hline Judaica & 0 & 0,00 & 0 & 0,00 & 0 & 0,00 & 0 & 0,00 & 0 & 0,00 \\
\hline Afrobrasileiro & 0 & 0,00 & 4 & 1,06 & 1 & 0,10 & 5 & 0,52 & 10 & 0,41 \\
\hline Religiões & 2 & 1,96 & 0 & 0,00 & 1 & 0,10 & 3 & 0,31 & 6 & 0,24 \\
\hline Orientais & & & & & & & & & & \\
\hline $\begin{array}{l}\text { Sem } \\
\text { religião/culto }\end{array}$ & 18 & 17,65 & 26 & 6,91 & 94 & 9,13 & 102 & 10,68 & 240 & 9,74 \\
\hline $\begin{array}{l}\text { Não } \\
\text { determinada }\end{array}$ & 5 & 4,90 & 21 & 5,59 & 49 & 4,76 & 45 & 4,71 & 120 & 4,87 \\
\hline Outras & 0 & 0,00 & 0 & 0,00 & 1 & 0,10 & 0 & 0,00 & 1 & 0,04 \\
\hline Não sabe & 0 & 0,00 & 1 & 0,27 & 3 & 0,29 & 1 & 0,04 & 5 & 0,20 \\
\hline Total & 102 & 100,00 & 376 & 100,00 & 1030 & 100,00 & 955 & 100,00 & 2463 & 100,00 \\
\hline
\end{tabular}

Tabela 7 - Distribuição dos indivíduos dos quatro grupos sociais segundo culto ou religião praticada. Santo André, SP, 2008.

\begin{tabular}{|c|c|c|c|c|c|c|c|c|c|c|}
\hline \multirow[b]{3}{*}{$\begin{array}{l}\text { Religião } \\
\text { praticada }\end{array}$} & \multicolumn{8}{|c|}{ GRUPO SOCIAL } & & \\
\hline & \multicolumn{2}{|c|}{ Central } & \multicolumn{2}{|c|}{ Quase Central } & \multicolumn{2}{|c|}{ Quase Periférico } & \multicolumn{2}{|c|}{ Periférico } & \multicolumn{2}{|c|}{ Total } \\
\hline & $\mathbf{N}$ & $\%$ & $\mathbf{N}$ & $\%$ & $\mathbf{N}$ & $\%$ & $\mathbf{N}$ & $\%$ & $\mathbf{N}$ & $\%$ \\
\hline Católica & 16 & 15,69 & 74 & 19,68 & 341 & 33,11 & 255 & 26,70 & 686 & 27,85 \\
\hline Test. de Jeová & 0 & 0,00 & 9 & 2,39 & 23 & 2,23 & 14 & 1,47 & 46 & 1,87 \\
\hline Histórico & 4 & 3,92 & 1 & ,27 & 18 & 1,75 & 26 & 2,72 & 49 & 1,99 \\
\hline Pentecostal & 5 & 4,90 & 81 & 21,54 & 207 & 20,10 & 259 & 27,12 & 552 & 22,41 \\
\hline Espírita & 15 & 14,71 & 9 & 2,39 & 20 & 1,94 & 15 & 1,57 & 59 & 2,40 \\
\hline Judaica & 0 & 0,00 & 0 & 0,00 & 0 & 0,00 & 0 & 0,00 & 0 & 0,00 \\
\hline Afrobrasileiro & 0 & 0,00 & 0 & 0,00 & 1 & 0,10 & 5 & 0,52 & 6 & 0,24 \\
\hline Religiões & 1 & 0,98 & 0 & 0,00 & 3 & 0,29 & 0 & 0,00 & 4 & 0,16 \\
\hline Orientais & & & & & & & & & & \\
\hline $\begin{array}{l}\text { Sem } \\
\text { religião/culto }\end{array}$ & 50 & 49,02 & 182 & 48,40 & 341 & 33,11 & 316 & 33,09 & 889 & 36,09 \\
\hline $\begin{array}{l}\text { Não } \\
\text { determinada }\end{array}$ & 11 & 10,78 & 19 & 5,05 & 72 & 6,99 & 59 & 6,18 & 161 & 6,54 \\
\hline Outras & 0 & 0,00 & 0 & 0,00 & 1 & 0,10 & 4 & 0,42 & 5 & 0,20 \\
\hline Não sabe & 0 & 0,00 & 1 & 0,27 & 3 & 0,29 & 2 & 0,21 & 6 & 0,24 \\
\hline Total & 102 & 100,00 & 376 & 100,00 & 1030 & 100,00 & 955 & 100,00 & 2463 & 100,00 \\
\hline
\end{tabular}

Quanto à escolaridade, verifica-se por meio da tabela 8 que o número de indivíduos com ensino fundamental incompleto aumenta proporcionalmente conforme a aumenta a exclusão ocorrendo o inverso em relação aos indivíduos com 
superior completo ou incompleto. Essa diferença entre os grupos é significativa pois $\mathrm{p}=0,00$.

Tabela 8 - Distribuição dos indivíduos dos quatro grupos sociais segundo escolaridade. Santo André, SP, 2008.

\begin{tabular}{|c|c|c|c|c|c|c|c|c|c|c|}
\hline \multirow[b]{3}{*}{ Escolaridade } & \multicolumn{8}{|c|}{ GRUPO SOCIAL } & \multirow{2}{*}{\multicolumn{2}{|c|}{ Total }} \\
\hline & \multicolumn{2}{|c|}{ Central } & \multicolumn{2}{|c|}{ Quase Central } & \multicolumn{2}{|c|}{ Quase Periférico } & \multicolumn{2}{|c|}{ Periférico } & & \\
\hline & $\mathbf{N}$ & $\%$ & $\mathbf{N}$ & $\%$ & $\mathbf{N}$ & $\%$ & $\mathbf{N}$ & $\%$ & $\mathbf{N}$ & $\%$ \\
\hline EF incompleto & 12 & 11,80 & 67 & 19,00 & 231 & 23,40 & 278 & 31,50 & 588 & 25,30 \\
\hline $\mathrm{EF}$ & & & & & & & & 29,50 & 640 & \\
\hline completo/Médio & & & & & & 28,60 & & & & \\
\hline Incompl & 21 & 20,60 & 77 & 21,80 & 282 & & 260 & & & 27,60 \\
\hline EM Completo & 14 & 13,70 & 106 & 30,00 & 279 & 28,30 & 197 & 22,30 & 596 & 25,60 \\
\hline Superior incompl/ & & & & & & 15,40 & & 7,40 & 342 & \\
\hline completo & 37 & 36,20 & 87 & 25,70 & 152 & & 66 & & & 14,70 \\
\hline Pós-graduação & 16 & 15,70 & 10 & 2,80 & 4 & 0,40 & 4 & 0,50 & 34 & 1,50 \\
\hline Supletivo EF/EM & 2 & 2,00 & 3 & 0,00 & 23 & 0,90 & 64 & 2,40 & 92 & 1,40 \\
\hline Sabe & & & & & & 1,60 & & 1,50 & 32 & \\
\hline $\begin{array}{l}\text { Ler/Escrever/Analf } \\
\text { abeto }\end{array}$ & 0 & 000 & 3 & 090 & 16 & & 13 & & & 1,40 \\
\hline Total & 102 & 100,00 & 353 & 100,00 & 987 & 100,00 & 882 & 100,00 & 2324 & 100,00 \\
\hline
\end{tabular}

Foram desconsiderados 139 indivíduos sobre os quais não havia informação.

No que diz respeito a benefícios oriundos do governo ou sociedade civil, verificou-se que apenas $22(2,14 \%)$ indivíduos do grupo quase periférico e 32 $(3,35 \%)$ membros do grupo periférico recebiam. O benefício recebido era o "bolsa família". O "banco do povo" e auxílios de ONGs foram citados por apenas uma pessoa e benefícios como cesta básica não foram citados.

\section{Formas de trabalhar}

No que diz respeito à condição de atividade verificou-se que o desemprego aumenta nos grupos mais excluídos. No grupo central há comparativamente menos assalariados do que nos outros grupos e mais indivíduos não inseridos (tabela 9). 
Tabela 9 - Distribuição dos indivíduos dos quatro grupos sociais segundo condição de atividade. Santo André, SP, 2008.

\begin{tabular}{|c|c|c|c|c|c|c|c|c|c|c|}
\hline \multirow[b]{3}{*}{$\begin{array}{l}\text { Condição de } \\
\text { atividade }\end{array}$} & \multicolumn{8}{|c|}{ GRUPO SOCIAL } & \multirow{2}{*}{\multicolumn{2}{|c|}{ Total }} \\
\hline & \multicolumn{2}{|c|}{ Central } & \multicolumn{2}{|c|}{ Quase Central } & \multicolumn{2}{|c|}{ Quase Periférico } & \multicolumn{2}{|c|}{ Periférico } & & \\
\hline & $\mathbf{N}$ & $\%$ & $\mathbf{N}$ & $\%$ & $\mathbf{N}$ & $\%$ & $\mathbf{N}$ & $\%$ & $\mathbf{N}$ & $\%$ \\
\hline Aposentado & 3 & 3,37 & 20 & 6,23 & 55 & 6,12 & 29 & 3,81 & 107 & 5,17 \\
\hline $\begin{array}{l}\text { Desemprega } \\
\text { do }\end{array}$ & 1 & 1,12 & 21 & 6,54 & 60 & 6,68 & 76 & 9,97 & 158 & 7,63 \\
\hline $\begin{array}{l}\text { Trabalho } \\
\text { assalariado }\end{array}$ & 32 & 35,96 & 142 & 44,24 & 421 & 46,88 & 337 & 44,23 & 932 & 45,02 \\
\hline Autônomo & 11 & 12,36 & 28 & 8,72 & 71 & 7,91 & 77 & 10,10 & 187 & 9,03 \\
\hline Bico & 0 & 0,00 & 2 & 0,62 & 18 & 2,00 & 25 & 3,28 & 45 & 2,17 \\
\hline Pensionista & 1 & 1,12 & 2 & 0,62 & 14 & 1,56 & 17 & 2,23 & 34 & 1,64 \\
\hline Empregador & 6 & 6,74 & 2 & 0,62 & 7 & 0,78 & 6 & 0,79 & 21 & 1,01 \\
\hline $\begin{array}{l}\text { Trabalho } \\
\text { familiar }\end{array}$ & 0 & 0,00 & 6 & 1,87 & 9 & 1,00 & 7 & 0,92 & 22 & 1,06 \\
\hline Dona de casa & 6 & 6,74 & 35 & 10,90 & 91 & 10,13 & 67 & 8,79 & 199 & 9,61 \\
\hline Não inserido & 24 & 26,97 & 49 & 15,26 & 133 & 14,81 & 109 & 14,30 & 315 & 15,22 \\
\hline $\begin{array}{l}\text { Afastado do } \\
\text { trabalho }\end{array}$ & 0 & 0,00 & 3 & 0,93 & 3 & 0,33 & 5 & 0,66 & 11 & 0,53 \\
\hline Estagiário & 5 & 5,62 & 11 & 3,43 & 16 & 1,78 & 7 & 0,92 & 39 & 1,88 \\
\hline Total & 89 & 100,00 & 321 & 100,00 & 898 & 100,00 & 762 & 100,00 & 2070* & 100,00 \\
\hline
\end{tabular}

*Foram desconsiderados 377 indivíduos que realmente não poderiam estar inseridos no mercado de trabalho por terem menos de 14 anos e 16 indivíduos sobre os quais não havia informação.

No que diz respeito às ocupações verificou-se que a proporção de indivíduos que trabalhava em atividades menos qualificadas aumentou conforme aumentava o grau de periferização dos grupos, conforme pode ser visto na tabela 10 . Os testes estatísticos demonstraram que existe evidência de dependência entre tipo de ocupação e classe social $(\mathrm{p}=0,00)$. Os grupos de ocupações foram definidos a partir do Código Brasileiro de Ocupações (CBO). 
Tabela 10 - Distribuição dos indivíduos dos quatro grupos sociais segundo tipo de ocupação Santo André, SP, 2008.

\section{GRUPOS SOCIAIS}

\begin{tabular}{lccccc} 
Grupos de Ocupações & Central & $\begin{array}{c}\text { Quase } \\
\text { Central }\end{array}$ & Quase Periférico & Periférico & Total \\
\hline & $\mathbf{N}$ & $\mathbf{N}$ & $\mathbf{N}$ & $\mathbf{N}$ & $\mathbf{N}$ \\
Planejamento e Organização & 17 & 28 & 50 & 24 & 119 \\
Empresário, Direção e Gerência & 15 & 25 & 35 & 19 & 94 \\
Não qualificado na execução & 4 & 18 & 75 & 95 & 192 \\
Semi-qualificado na execução & 5 & 38 & 168 & 157 & 368 \\
Qualificado na Execução & 5 & 22 & 43 & 35 & 105 \\
Serviços Gerais & 0 & 6 & 19 & 16 & 41 \\
Serviços de Escritório & 0 & 8 & 22 & 7 & 37 \\
Não operacional/apoio & 2 & 16 & 73 & 54 & 145 \\
Mal definidas & 6 & 27 & 53 & 39 & 125 \\
Total & $\mathbf{5 4}$ & $\mathbf{1 8 8}$ & $\mathbf{5 3 8}$ & $\mathbf{4 4 6}$ & $\mathbf{1 2 2 6}$ \\
\hline
\end{tabular}

* Foram excluídos 25 indivíduos sobre os quais não havia informação

Quanto ao registro em carteira, verificou-se que as famílias apresentam certa segurança no trabalho já que mais da metade dos trabalhadores das famílias dos grupos quase central, quase periférico e periférico possuíam registro em carteira. Verifica-se que o grupo central apresenta comparativamente menos registro em carteira, sendo que nesse grupo há mais empregadores (tabela 11).

Tabela 11 - Distribuição dos trabalhadores dos quatro grupos sociais segundo registro em carteira. Santo André, SP, 2008.

\begin{tabular}{|c|c|c|c|c|c|c|c|c|c|c|}
\hline \multirow[b]{3}{*}{$\begin{array}{l}\text { Registro em } \\
\text { carteira }\end{array}$} & \multicolumn{8}{|c|}{ GRUPO SOCIAL } & \multirow{2}{*}{\multicolumn{2}{|c|}{ Total }} \\
\hline & \multicolumn{2}{|c|}{ Central } & \multicolumn{2}{|c|}{ Quase Central } & \multicolumn{2}{|c|}{ Quase Periférico } & \multicolumn{2}{|c|}{ Periférico } & & \\
\hline & $\mathbf{N}$ & $\%$ & $\mathbf{N}$ & $\%$ & $\mathbf{N}$ & $\%$ & $\mathbf{N}$ & $\%$ & $\mathbf{N}$ & $\%$ \\
\hline Sim & 26 & 49,06 & 117 & 61,58 & 341 & 62,80 & 283 & 61,26 & 767 & 61,46 \\
\hline Não & 27 & 50,94 & 73 & 38,42 & 204 & 37,20 & 180 & 38,74 & 481 & 38,54 \\
\hline Total & 53 & 100,00 & 190 & 100,00 & 545 & 100,00 & 463 & 100,00 & $1251 *$ & 100,00 \\
\hline
\end{tabular}

*Foram desconsiderados 278 indivíduos que estavam desempregados, aposentados, afastados do trabalho ou eram pensionistas, não inseridos ou donas de casa.

Em relação à renda verificou-se que grande parcela da população encontra-se na faixa salarial de 800 reais como pode ser verificado no gráfico 1 . Um gráfico comparativo entre os quatro grupos sociais será apresentado posteriormente. 
Gráfico 1- Distribuição dos indivíduos segundo renda principal. Santo André, SP, 2008 .

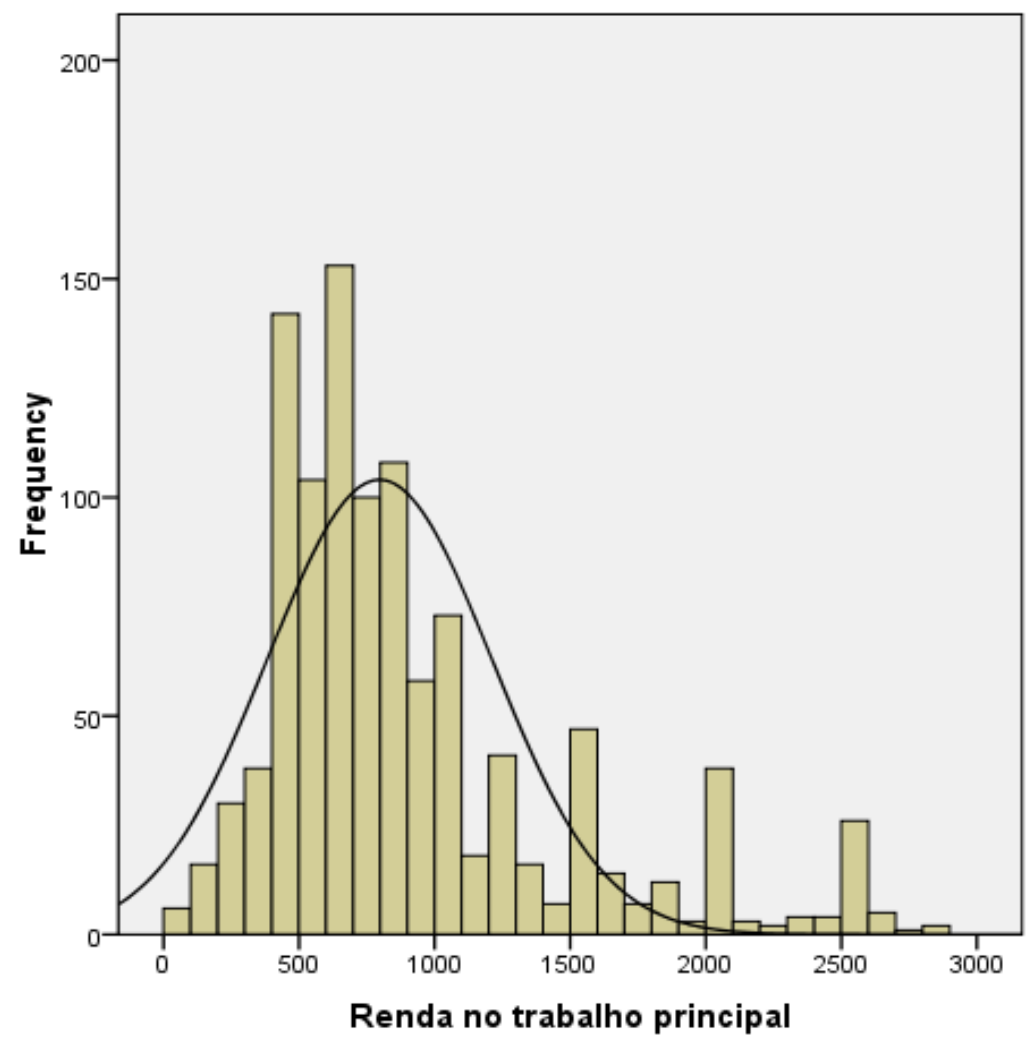

Mean $=871,27$ td. Dev. $=543,972$ $\mathrm{N}=1.078$

Quanto ao setor de trabalho verificou-se que grande parte dos trabalhadores dos quatro grupos trabalhava no setor privado (tabela 12). Observe-se que há uma discreta tendência a reduzir a vinculação ao setor público à medida que os grupos se periferizam. Será realizado o agrupamento por tipo de ocupação e local de trabalho para posterior apresentação.

Tabela 12- Distribuição dos trabalhadores dos quatro grupos sociais segundo setor de trabalho. Santo André, SP, 2008.

\begin{tabular}{|c|c|c|c|c|c|c|c|c|c|c|}
\hline \multirow[b]{3}{*}{$\begin{array}{l}\text { Setor } \\
\text { trabalho }\end{array}$} & \multicolumn{8}{|c|}{ GRUPO SOCIAL } & \multirow{2}{*}{\multicolumn{2}{|c|}{ Total }} \\
\hline & \multicolumn{2}{|c|}{ Central } & \multicolumn{2}{|c|}{ Quase Central } & \multicolumn{2}{|c|}{$\begin{array}{c}\text { Quase } \\
\text { Periférico }\end{array}$} & \multicolumn{2}{|c|}{ Periférico } & & \\
\hline & $\mathbf{N}$ & $\%$ & $\mathbf{N}$ & $\%$ & $\mathbf{N}$ & $\%$ & $\mathbf{N}$ & $\%$ & $\mathbf{N}$ & $\%$ \\
\hline Público & 8 & 15,09 & 21 & 10,88 & 54 & 9,93 & 41 & 8,89 & 124 & 9,91 \\
\hline Privado & 45 & 84,91 & 172 & 89,12 & 488 & 89,71 & 419 & 90,89 & 1124 & 89,85 \\
\hline Misto & 0 & 0,00 & 0 & 0,00 & 2 & 0,37 & 1 & 0,22 & 3 & 0,24 \\
\hline Total & 53 & $\begin{array}{r}100,0 \\
0\end{array}$ & 193 & 100,00 & 544 & 100,00 & 461 & 100,00 & $1251 *$ & 100,00 \\
\hline
\end{tabular}

* Foram desconsiderados 278 indivíduos que estavam desempregados, aposentados, afastados do trabalho ou eram pensionistas, não inseridos ou donas de casa. 
No que diz respeito ao tempo de serviço no emprego atual verificou-se que os trabalhadores do grupo central estavam trabalhando há uma média de 39,28 meses no mesmo emprego, os do grupo central há 41,13 meses, os indivíduos do grupo quase periférico trabalhavam há 41,87 meses e os do grupo periférico há 41,87 meses em média. A diferença entre os grupos foi significativa $(\mathrm{p}=0,045)$. Será necessário analisar mais profundamente as causas da aparente maior estabilidade do grupo periférico no mesmo emprego.

O tempo médio gasto pelos indivíduos para ir e voltar do trabalho ou da escola foi de 54 minutos para o grupo central, 56 para o quase central, 61 minutos para o quase periférico e 68 minutos para o periférico, verificando-se que quanto mais excluído o grupo mais tempo é gasto no percurso para o trabalho e a escola $(\mathrm{p}=0,026)$.

No que diz respeito aos benefícios verificou-se que em cada grupo social o conjunto dos que não recebiam era mais expressivo. Dos benefícios recebidos verificou-se que o vale-refeição era o mais preponderante seguido pela cesta-básica. $\mathrm{O}$ vale-transporte estava mais presente entre os trabalhadores do grupo periférico (tabela 13). Ressalta-se que os benefícios abaixo foram citados como os mais relevantes pelos entrevistados. Cada indivíduo poderia citar até três benefícios, que $472(37,82 \%)$ trabalhadores recebia até dois benefícios e $231(18,5 \%)$ recebiam até três. Será construída tabela apresentando as principais combinações de benefícios nos quatro grupos.

Tabela 13- Distribuição dos trabalhadores dos quatro grupos sociais segundo benefício oriundo do trabalho. Santo André, SP, 2008.

\begin{tabular}{|c|c|c|c|c|c|c|c|c|c|c|}
\hline \multirow[b]{3}{*}{$\begin{array}{l}\text { Benefício } \\
\text { advindo } \\
\text { trabalho }\end{array}$} & \multicolumn{8}{|c|}{ GRUPO SOCIAL } & \multirow{2}{*}{\multicolumn{2}{|c|}{ Total }} \\
\hline & \multicolumn{2}{|c|}{ Central } & \multicolumn{2}{|c|}{ Quase Central } & \multicolumn{2}{|c|}{ Quase Periférico } & \multicolumn{2}{|c|}{ Periférico } & & \\
\hline & $\mathbf{N}$ & $\%$ & $\mathbf{N}$ & $\%$ & $\mathbf{N}$ & $\%$ & $\mathbf{N}$ & $\%$ & $\mathbf{N}$ & $\%$ \\
\hline Cesta básica & 7 & 12,96 & 32 & 16,58 & 84 & 15,58 & 73 & 15,80 & 196 & 15,71 \\
\hline Vale refeição & 10 & 18,52 & 47 & 24,35 & 109 & 20,22 & 77 & 16,67 & 243 & 19,47 \\
\hline Vale & 3 & 5,56 & 4 & 2,07 & 19 & 3,53 & 8 & 1,73 & 34 & 2,72 \\
\hline Supermercado & & & & & & & & & & \\
\hline Ass.Médica & 4 & 7,41 & 20 & 10,36 & 46 & 8,53 & 35 & 7,58 & 105 & 8,41 \\
\hline Assistência & 0 & 0,00 & 1 & 0,52 & 1 & 0,19 & 3 & 0,65 & 5 & 0,40 \\
\hline Odontológica & & & & & & & & & & \\
\hline Vale transporte & 6 & 11,11 & 16 & 8,29 & 54 & 10,02 & 64 & 13,85 & 140 & 11,22 \\
\hline Não recebe & 24 & 44,44 & 73 & 37,82 & 225 & 41,74 & 201 & 43,51 & 523 & 41,91 \\
\hline Outros (Quais?) & 0 & 0,00 & 0 & 0,00 & 1 & 0,19 & 1 & 0,22 & 2 & 0,16 \\
\hline Total* & 54 & 100,00 & 193 & 100,00 & 530 & 100,00 & 462 & 100,00 & $1248 *$ & 100,00 \\
\hline
\end{tabular}

* Foram desconsiderados 03 indivíduos sobre os quais não havia informação a respeito.

\section{Formas de viver}

Quanto às características de moradia verificou-se que no grupo central a totalidade das casas era de alvenaria com acabamento sendo que esse se constituiu em principal material das casas das famílias dos outros três grupos (tabela 14). Verificou-se ainda que a maior parte das famílias nos quatro grupos morava em casas ou apartamentos isolados sendo que 8,73\% das famílias do grupo periférico viviam 
em favelas e 11,79\% em quintal comum (tabela 15). Quanto à propriedade da habitação a grande parte das famílias do grupo central possuía casa própria em terreno regular. Já as famílias dos grupos quase-central e quase-periférico possuíam principalmente casa própria em terreno regular e casa alugada. Por sua vez, quase metade das famílias do grupo periférico morava em casas próprias em terreno irregular, alugada e cedida (tabela 16). No grupo periférico a proporção de famílias que não pagam IPTU foi maior do que nos outros grupos, sendo que $1,4 \%$ das famílias são isentas (tabela 17).

Tabela 14 - Distribuição das famílias dos quatro grupos sociais segundo material da habitação. Santo André, SP, 2008.

\begin{tabular}{|c|c|c|c|c|c|c|c|c|c|c|}
\hline \multirow[b]{3}{*}{$\begin{array}{l}\text { Material da } \\
\text { habitação }\end{array}$} & \multicolumn{8}{|c|}{ GRUPO SOCIAL } & \multirow{2}{*}{\multicolumn{2}{|c|}{ Total }} \\
\hline & \multicolumn{2}{|c|}{ Central } & \multicolumn{2}{|c|}{ Quase Central } & \multicolumn{2}{|c|}{ Quase Periférico } & \multicolumn{2}{|c|}{ Periférico } & & \\
\hline & $\mathbf{N}$ & $\%$ & $\mathbf{N}$ & $\%$ & $\mathbf{N}$ & $\%$ & $\mathbf{N}$ & $\%$ & $\mathbf{N}$ & $\%$ \\
\hline $\begin{array}{l}\text { Alvenaria } \\
\text { com } \\
\text { acabamento }\end{array}$ & 26 & 100,00 & 78 & 91,76 & 222 & 89,16 & 180 & 78,60 & 506 & 85,91 \\
\hline $\begin{array}{l}\text { Alvenaria } \\
\text { sem } \\
\text { acabamento }\end{array}$ & 0 & 0,00 & 5 & 5,88 & 26 & 10,44 & 44 & 19,21 & 75 & 12,73 \\
\hline Madeira & 0 & 0,00 & 2 & 2,35 & 1 & 0,40 & 3 & 1,31 & 6 & 1,02 \\
\hline $\begin{array}{l}\text { Material } \\
\text { aproveitado } \\
\text { (papelão, } \\
\text { plástico) }\end{array}$ & 0 & 0,00 & 0 & 0,00 & 0 & 0,00 & 2 & 0,87 & 2 & ,34 \\
\hline Total & 26 & 100,00 & 85 & 100,00 & 249 & 100,00 & 229 & 100,00 & 589 & 100,00 \\
\hline
\end{tabular}

Tabela 15 - Distribuição das famílias dos quatro grupos sociais segundo localização da moradia. Santo André, SP, 2008.

\begin{tabular}{|c|c|c|c|c|c|c|c|c|c|c|}
\hline \multirow[b]{3}{*}{$\begin{array}{l}\text { Localização } \\
\text { moradia }\end{array}$} & \multicolumn{8}{|c|}{ GRUPO SOCIAL } & \multirow{2}{*}{\multicolumn{2}{|c|}{ Total }} \\
\hline & \multicolumn{2}{|c|}{ Central } & \multicolumn{2}{|c|}{ Quase Central } & \multicolumn{2}{|c|}{ Quase Periférico } & \multicolumn{2}{|c|}{ Periférico } & & \\
\hline & $\mathbf{N}$ & $\%$ & $\mathbf{N}$ & $\%$ & $\mathbf{N}$ & $\%$ & $\mathbf{N}$ & $\%$ & $\mathbf{N}$ & $\%$ \\
\hline Favela & 0 & 0,00 & 2 & 2,35 & 8 & 3,21 & 20 & 8,73 & 30 & 5,09 \\
\hline Cortiço & 0 & ,00 & 1 & 1,18 & 2 & 0,80 & 1 & 0,44 & 4 & 0,68 \\
\hline Casa/apto & 25 & 96,15 & 79 & 92,94 & 216 & 86,75 & 177 & 77,29 & 497 & 84,38 \\
\hline CDHU, COHAB & 1 & 3,85 & 1 & 1,18 & 3 & 1,20 & 4 & 1,75 & 9 & 1,53 \\
\hline Quintal comum & 0 & 0,00 & 2 & 2,35 & 20 & 8,03 & 27 & 11,79 & 49 & 8,32 \\
\hline Total & 26 & 100,00 & 85 & 100,00 & 249 & 100,00 & 229 & 100,00 & 589 & 100,00 \\
\hline
\end{tabular}


Tabela 16 - Distribuição das famílias dos quatro grupos sociais segundo propriedade da residência. Santo André, SP, 2008.

\begin{tabular}{|c|c|c|c|c|c|c|c|c|c|c|}
\hline \multirow[b]{3}{*}{$\begin{array}{l}\text { Propriedade da } \\
\text { residência }\end{array}$} & \multicolumn{8}{|c|}{ GRUPO SOCIAL } & \multirow{2}{*}{\multicolumn{2}{|c|}{ Total }} \\
\hline & \multicolumn{2}{|c|}{ Central } & \multicolumn{2}{|c|}{ Quase Central } & \multicolumn{2}{|c|}{ Quase Periférico } & \multicolumn{2}{|c|}{ Periférico } & & \\
\hline & $\mathbf{N}$ & $\%$ & $\mathbf{N}$ & $\%$ & $\mathbf{N}$ & $\%$ & $\mathbf{N}$ & $\%$ & $\mathbf{N}$ & $\%$ \\
\hline Própria regular & 22 & 84,62 & 61 & 71,76 & 149 & 59,84 & 137 & 60,09 & 369 & 62,76 \\
\hline Própria irregular & 0 &, 00 & 3 & 3,53 & 10 & 4,02 & 26 & 11,40 & 39 & 6,63 \\
\hline Alugada & 3 & 11,54 & 15 & 17,65 & 55 & 22,09 & 36 & 15,79 & 109 & 18,54 \\
\hline Cedida & 1 & 3,85 & 4 & 4,71 & 31 & 12,45 & 24 & 10,53 & 60 & 10,20 \\
\hline Financiada & 0 & 0,00 & 2 & 2,35 & 4 & 1,61 & 4 & 1,75 & 10 & 1,70 \\
\hline Outro & 0 & 0,00 & 0 & 0,00 & 0 & 0,00 & 1 & 0,44 & 1 & 0,17 \\
\hline Total & 26 & 100,00 & 85 & 100,00 & 249 & 100,00 & 229 & 100,00 & 589 & 100,00 \\
\hline
\end{tabular}

Tabela 17 - Distribuição das famílias dos quatro grupos sociais segundo pagamento do IPTU. Santo André, SP, 2008.

\begin{tabular}{|c|c|c|c|c|c|c|c|c|c|c|c|}
\hline \multirow[b]{3}{*}{ Paga IPTU } & \multicolumn{9}{|c|}{ GRUPO SOCIAL } & \multirow{2}{*}{\multicolumn{2}{|c|}{ Total }} \\
\hline & \multicolumn{3}{|c|}{ Central } & \multicolumn{2}{|c|}{ Quase Central } & \multicolumn{2}{|c|}{ Quase Periférico } & \multicolumn{2}{|c|}{ Periférico } & & \\
\hline & & $\mathbf{N}$ & $\%$ & $\mathbf{N}$ & $\%$ & $\mathbf{N}$ & $\%$ & $\mathbf{N}$ & $\%$ & $\mathbf{N}$ & $\%$ \\
\hline Sim & & 24 & 96,00 & 74 & 88,10 & 191 & 78,28 & 153 & 71,16 & 442 & 77,82 \\
\hline Não & & 1 & 4,00 & 10 & 11,90 & 52 & 21,31 & 59 & 27,44 & 122 & 21,48 \\
\hline Isento & & 0 & 0,00 & 0 & 0,00 & 1 & 0,41 & 3 & 1,40 & 4 & 0,70 \\
\hline Total & 25 & & 100,00 & 84 & 100,00 & 244 & 100,00 & 215 & 100,00 & $568^{*}$ & 100,00 \\
\hline
\end{tabular}

* Foram subtraídas 21 famílias, pois os entrevistados não souberam responder

No que diz respeito ao tempo de moradia, verificou-se que as famílias do grupo central moravam em média há 12 anos no mesmo endereço, as do grupo quase-central e quase periférico moravam há 14 anos e as do grupo periférico viviam em média há 11 anos na mesma casa.

Ao se verificar mudança de moradia nos últimos 5 anos identificou-se que $30,77 \%$ das famílias do grupo central, $27,06 \%$ das do grupo quase central, $26,9 \%$ do grupo quase periférico e $34,50 \%$ do periférico mudaram de casa nesse período. A melhora das condições financeiras esteve presente para os dos grupos central, quase central e quase periférico. Entretanto no grupo central a transferência de emprego apresentou a mesma proporção Ressalta-se que casamento e separação foram causas importantes para mudança de moradia nos grupos quase periférico e periférico (tabela 18 
Tabela 18 - Distribuição das famílias dos quatro grupos sociais segundo motivo de mudança nos últimos cinco anos. Santo André, SP, 2008.

\begin{tabular}{|c|c|c|c|c|c|c|c|c|c|c|}
\hline \multicolumn{11}{|c|}{ GRUPO SOCIAL } \\
\hline & \multicolumn{2}{|c|}{ Central } & \multicolumn{2}{|c|}{ Quase Central } & \multicolumn{2}{|c|}{ Quase Periférico } & \multicolumn{2}{|c|}{ Periférico } & \multicolumn{2}{|c|}{ Total } \\
\hline & $\mathbf{N}$ & $\%$ & $\mathbf{N}$ & $\%$ & $\mathbf{N}$ & $\%$ & $\mathbf{N}$ & $\%$ & $\mathbf{N}$ & $\%$ \\
\hline $\begin{array}{l}\text { Transferência de } \\
\text { emprego }\end{array}$ & 2 & 25,00 & 1 & 4,35 & 4 & 5,97 & 7 & 8,64 & 14 & 7,82 \\
\hline $\begin{array}{l}\text { Transferência de } \\
\text { escola }\end{array}$ & 0 & 0,00 & 0 & 0,00 & 1 & 1,49 & 0 & 0,00 & 1 & 0,56 \\
\hline Segurança & 0 & 0,00 & 1 & 4,35 & 1 & 1,49 & 2 & 2,47 & 4 & 2,23 \\
\hline $\begin{array}{l}\text { Casamento/ } \\
\text { Separação }\end{array}$ & 1 & 12,50 & 2 & 8,70 & 16 & 23,88 & 17 & 20,99 & 36 & 20,11 \\
\hline $\begin{array}{ll}\text { Piora } & \text { das } \\
\text { condições } & \\
\text { financeiras } & \end{array}$ & 1 & 12,50 & 2 & 8,70 & 6 & 8,96 & 10 & 12,35 & 19 & 10,61 \\
\hline $\begin{array}{ll}\text { Melhora } & \text { de } \\
\text { condições } & \\
\text { financeiras } & \end{array}$ & 2 & 25,00 & 9 & 39,13 & 19 & 28,36 & 16 & 19,75 & 46 & 25,70 \\
\hline $\begin{array}{l}\text { Melhora da } \\
\text { Infra-estrutura }\end{array}$ & 1 & 12,50 & 4 & 17,39 & 14 & 20,90 & 16 & 19,75 & 35 & 19,55 \\
\hline Outro & 1 & 12,50 & 4 & 17,39 & 6 & 8,96 & 10 & 14,81 & 21 & 12,85 \\
\hline Não Sabe & 0 & 0,00 & 0 & 0,00 & 0 & 0,00 & 1 & 1,23 & 1 & 0,56 \\
\hline Total & 8 & 100,00 & 23 & 100,00 & 67 & 100,00 & 79 & 100,00 & 177 & 100,00 \\
\hline
\end{tabular}

Quanto à posse de bens e serviços verificou-se que os itens que mais diferenciavam os grupos foram o número de aparelhos de rádio e de televisão, a posse de vídeo/DVD e freezer, o número de banheiros, a quantidade de cômodos para dormir, a posse de automóvel, computador, computador com internet e de aspirador de pó, a presença de empregados mensallistas $(\mathrm{p}=0,00)$. Posse de geladeira e de geladeira duplex também mostraram forte relação com a discriminação dos grupos sociais ( $\mathrm{p}=0,005$ e 0,001 respectivamente) (quadro 1 ).

No que diz respeito ao acesso aos serviços de saneamento básico, identificouse que a totalidade das famílias dos grupos central e periférico e mais de $90 \%$ das famílias dos grupos quase periférico e periférico tinham acesso à água, luz e coleta de lixo (tabelas 19, 20, 21). Em relação ao acesso a esgoto, apenas o grupo central tinha acesso em sua totalidade. $\mathrm{O}$ acesso diminui para os grupos quase central e quase periférico sendo que aproximadamente $30 \%$ das famílias do grupo periférico não tinham acesso a esse serviço (tabela 22). Entretanto, quando se verificou a legalidade do acesso à água e luz observou-se que o grupo central em sua totalidade recebia a conta desses serviços enquanto que a proporção diminuiu discretamente nos outros três grupos (tabelas 23 e 24).

Em relação ao destino do lixo verificou-se que a totalidade das famílias do grupo central e a quase totalidade das famílias dos outros três grupos tinham acesso à coleta por caminhões de lixo. Essa homogeneidade não foi observada em relação ao destino do esgoto. Enquanto a totalidade das moradias das famílias dos grupos central, quase central e quase periférico tinha como destino o encanamento dos serviços públicos, $22,71 \%$ das habitações do grupo periférico desprezavam o esgoto em fossas sépticas (tabela 25 e 26). 
Quadro 1 - Percentual de famílias dos quatro grupos sociais que possuem bens eletrodomésticos e acesso a serviços. Santo André, SP, 2008.

\begin{tabular}{|c|c|c|c|c|c|c|c|c|}
\hline \multicolumn{9}{|c|}{ GRUPO SOCIAL } \\
\hline & \multicolumn{2}{|c|}{ Central } & \multicolumn{2}{|c|}{ Quase Central } & \multicolumn{2}{|c|}{ Quase Periférico } & \multicolumn{2}{|c|}{ Periférico } \\
\hline & $\mathbf{N}$ & \% & $\mathbf{N}$ & 응 & $\mathbf{N}$ & $\frac{\circ}{0}$ & $\mathbf{N}$ & $\frac{\circ}{0}$ \\
\hline Total & 26 & 100,00 & 85 & 100,00 & 249 & 100,00 & 229 & 100,00 \\
\hline \multicolumn{9}{|c|}{ Rádio/aparelho de Som } \\
\hline Não tem & 1 & 3,85 & 3 & 3,53 & 21 & 8,43 & 22 & 9,61 \\
\hline 1 ou 2 & 13 & 50,0 & 56 & 65,88 & 193 & 77,51 & 185 & 80,79 \\
\hline 3 ou mais & 12 & 46,15 & 26 & 30,59 & 35 & 14,06 & 22 & 9,6 \\
\hline \multicolumn{9}{|l|}{ TV } \\
\hline Não tem & 0 & 0,00 & 1 & 1,18 & 1 & 0,40 & 3 & 1,31 \\
\hline 1 ou 2 & 7 & 26,92 & 35 & 41,17 & 172 & 69,07 & 183 & 79,91 \\
\hline 3 ou mais & 19 & 73,08 & 49 & 57,65 & 76 & 30,53 & 43 & 18,78 \\
\hline \multicolumn{9}{|l|}{ Banheiro } \\
\hline Não tem & 0 & 0,00 & 0 & 0,00 & 1 & 0,40 & 0 & 0,00 \\
\hline 1 ou 2 & 10 & 38,46 & 65 & 76,47 & 219 & 87,95 & 216 & 94,32 \\
\hline 3 ou mais & 16 & 61,54 & 20 & 23,53 & 29 & 11,65 & 13 & 5,68 \\
\hline \multicolumn{9}{|c|}{ Automóvel } \\
\hline Não tem & 1 & 3,85 & 22 & 25,88 & 86 & 34,54 & 128 & 55,90 \\
\hline 1 ou 2 & 23 & 88,46 & 51 & 60,00 & 151 & 60,64 & 98 & 54,14 \\
\hline 3 ou mais & 2 & 7,69 & 12 & 14,12 & 12 & 4,82 & 3 & 1,31 \\
\hline \multicolumn{9}{|c|}{ Aspirador de pó } \\
\hline Não & 4 & 15,38 & 32 & 37,65 & 142 & 57,03 & 164 & 71,62 \\
\hline Sim & 22 & 84,62 & 53 & 62,36 & 107 & 42,97 & 65 & 28,38 \\
\hline \multicolumn{9}{|c|}{ Máquina de lavar roupa } \\
\hline Não & 1 & 3,85 & 6 & 7,06 & 33 & 13,25 & 35 & 15,28 \\
\hline Sim & 25 & 96,15 & 79 & 92,94 & 216 & 86,74 & 194 & 84,72 \\
\hline \multicolumn{9}{|c|}{ Vídeo/DVD } \\
\hline Não tem & 1 & 3,85 & 6 & 7,06 & 25 & 10,04 & 20 & 8,73 \\
\hline 1 ou 2 & 19 & 73,08 & 66 & 77,65 & 213 & 85,54 & 206 & 89,96 \\
\hline 3 ou mais & 6 & 23,07 & 13 & 15,29 & 11 & 4,42 & 3 & 1,31 \\
\hline \multicolumn{9}{|l|}{ Geladeira } \\
\hline Não & 14 & 53,85 & 30 & 35,29 & 102 & 40,96 & 64 & 27,95 \\
\hline Sim & 12 & 46,15 & 55 & 64,71 & 147 & 59,04 & 165 & 72,05 \\
\hline \multicolumn{9}{|c|}{ Geladeira duplex } \\
\hline Não & 11 & 42,31 & 49 & 57,65 & 142 & 57,03 & 163 & 71,18 \\
\hline Sim & 15 & 57,69 & 36 & 42,36 & 107 & 42,97 & 66 & 28,82 \\
\hline \multicolumn{9}{|l|}{ Freezer } \\
\hline Não & 14 & 53,85 & 58 & 68,24 & 207 & 83,13 & 196 & 85,59 \\
\hline Sim & 12 & 46,15 & 27 & 31,77 & 42 & 16,76 & 33 & 14,41 \\
\hline \multicolumn{9}{|c|}{ Computador } \\
\hline Não & 2 & 7,69 & 9 & 10,59 & 63 & 25,30 & 111 & 48,47 \\
\hline Sim & 24 & 92,11 & 76 & 89,41 & 186 & 74,70 & 118 & 51,53 \\
\hline \multicolumn{9}{|c|}{ Computador com internet } \\
\hline Não & 2 & 7,69 & 14 & 16,47 & 93 & 37,35 & 133 & 58,08 \\
\hline Sim & 24 & 92,31 & 71 & 83,53 & 156 & 62,65 & 96 & 41,92 \\
\hline \multicolumn{9}{|c|}{ Cômodos para dormir } \\
\hline 1 & 0 & 0,00 & 6 & 7,06 & 38 & 15,26 & 56 & 24,45 \\
\hline 2 & 6 & 23,08 & 29 & 34,12 & 128 & 51,40 & 101 & 44,10 \\
\hline 3 & 18 & 69,23 & 40 & 47,06 & 70 & 28,11 & 59 & 25,76 \\
\hline 4 ou mais & 2 & 7,69 & 10 & 11,76 & 13 & 5,23 & 13 & 5,69 \\
\hline Empregac & & & & & & & & \\
\hline Não & 17 & 65,38 & 68 & 80,00 & 234 & 93,98 & 226 & 98,69 \\
\hline Sim & 9 & 34,62 & 17 & 20,00 & 15 & 6,02 & 3 & 1,31 \\
\hline
\end{tabular}


Tabela 19 - Distribuição das famílias dos quatro grupos sociais segundo acesso à água. Santo André, SP, 2008.

\begin{tabular}{|c|c|c|c|c|c|c|c|c|c|c|}
\hline \multirow[b]{3}{*}{$\begin{array}{l}\text { Acesso } \\
\text { à água }\end{array}$} & \multicolumn{8}{|c|}{ GRUPO SOCIAL } & \multirow{2}{*}{\multicolumn{2}{|c|}{ Total }} \\
\hline & \multicolumn{2}{|c|}{ Central } & \multicolumn{2}{|c|}{ Quase Central } & \multicolumn{2}{|c|}{ Quase Periférico } & \multicolumn{2}{|c|}{ Periférico } & & \\
\hline & $\mathbf{N}$ & $\%$ & $\mathbf{N}$ & $\%$ & $\mathbf{N}$ & $\%$ & $\mathbf{N}$ & $\%$ & $\mathbf{N}$ & $\%$ \\
\hline Sim & 26 & 100,00 & 85 & 100,00 & 246 & 98,80 & 215 & 93,89 & 572 & 97,11 \\
\hline Não & 0 & 0,00 & 0 & 0,00 & 3 & 1,20 & 14 & 6,11 & 17 & 2,89 \\
\hline Total & 26 & 100,0 & 85 & 100,0 & 249 & 100,00 & 229 & 100,00 & 589 & 100,00 \\
\hline
\end{tabular}

Tabela 20 - Distribuição das famílias dos quatro grupos sociais segundo acesso à luz. Santo André, SP, 2008.

\begin{tabular}{|c|c|c|c|c|c|c|c|c|c|c|}
\hline \multirow{3}{*}{$\begin{array}{l}\text { Acesso } \\
\text { à luz }\end{array}$} & \multicolumn{8}{|c|}{ GRUPO SOCIAL } & \multirow{2}{*}{\multicolumn{2}{|c|}{ Total }} \\
\hline & \multicolumn{2}{|c|}{ Central } & \multicolumn{2}{|c|}{ Quase Central } & \multicolumn{2}{|c|}{ Quase Periférico } & \multicolumn{2}{|c|}{ Periférico } & & \\
\hline & $\mathbf{N}$ & $\%$ & $\mathbf{N}$ & $\%$ & $\mathbf{N}$ & $\%$ & $\mathbf{N}$ & $\%$ & $\mathbf{N}$ & $\%$ \\
\hline Sim & 26 & 100,00 & 85 & 100,00 & 247 & 99,20 & 220 & 96,07 & 578 & 98,13 \\
\hline Não & 0 & 0,00 & 0 & 0,00 & 2 & 0,80 & 9 & 3,93 & 11 & 1,87 \\
\hline Total & 26 & 100,00 & 85 & 100,00 & 249 & 100,00 & 229 & 100,00 & 589 & 100,00 \\
\hline
\end{tabular}

Tabela 21 - Distribuição das famílias dos quatro grupos sociais segundo acesso à coleta de lixo. Santo André, SP, 2008.

\begin{tabular}{|c|c|c|c|c|c|c|c|c|c|c|}
\hline \multirow[b]{3}{*}{$\begin{array}{l}\text { Acesso a } \\
\text { coleta de } \\
\text { lixo }\end{array}$} & \multicolumn{8}{|c|}{ GRUPO SOCIAL } & \multirow{2}{*}{\multicolumn{2}{|c|}{ Total }} \\
\hline & \multicolumn{2}{|c|}{ Central } & \multicolumn{2}{|c|}{ Quase Central } & \multicolumn{2}{|c|}{ Quase Periférico } & \multicolumn{2}{|c|}{ Periférico } & & \\
\hline & $\mathbf{N}$ & $\%$ & $\mathbf{N}$ & $\%$ & $\mathbf{N}$ & $\%$ & $\mathbf{N}$ & $\%$ & $\mathbf{N}$ & $\%$ \\
\hline Sim & 26 & 100,00 & 85 & 100,00 & 247 & 99,20 & 221 & 96,51 & 579 & 98,30 \\
\hline Não & 0 & 0,00 & 0 & 0,00 & 1 & 0,40 & 8 & 3,49 & 9 & 1,53 \\
\hline $\begin{array}{l}\text { Sem } \\
\text { informaçã } \\
\text { o }\end{array}$ & 0 & 0,00 & 0 & 0,00 & 1 & 0,40 & 0 & 0,00 & 1 & 0,17 \\
\hline Total & 26 & 100,00 & 85 & 100,00 & 249 & 100,00 & 229 & 100,00 & 589 & 100,00 \\
\hline
\end{tabular}


Tabela 22 - Distribuição das famílias dos quatro grupos sociais segundo acesso a esgoto. Santo André, SP, 2008.

\begin{tabular}{|c|c|c|c|c|c|c|c|c|c|c|}
\hline \multirow[b]{3}{*}{$\begin{array}{l}\text { Acesso } \\
\text { a esgoto }\end{array}$} & \multicolumn{8}{|c|}{ GRUPO SOCIAL } & \multirow{2}{*}{\multicolumn{2}{|c|}{ Total }} \\
\hline & \multicolumn{2}{|c|}{ Central } & \multicolumn{2}{|c|}{ Quase Central } & \multicolumn{2}{|c|}{ Quase Periférico } & \multicolumn{2}{|c|}{ Periférico } & & \\
\hline & $\mathbf{N}$ & $\%$ & $\mathbf{N}$ & $\%$ & $\mathbf{N}$ & $\%$ & $\mathbf{N}$ & $\%$ & $\mathbf{N}$ & $\%$ \\
\hline Sim & 26 & 100,00 & 84 & 98,82 & 238 & 95,58 & 165 & 72,05 & 513 & 87,10 \\
\hline Não & 0 & 0,00 & 0 &, 00 & 9 & 3,61 & 62 & 27,07 & 71 & 12,05 \\
\hline $\begin{array}{l}\text { Sem } \\
\text { informa } \\
\text { ção }\end{array}$ & 0 & 0,00 & 1 & 1,18 & 2 & 0,80 & 2 & 0,87 & 5 & 0,85 \\
\hline Total & 26 & 100,00 & 85 & 100,00 & 249 & 100,00 & 229 & 100,00 & 589 & 100,00 \\
\hline
\end{tabular}

Tabela 23 - Distribuição das famílias dos quatro grupos sociais segundo recebimento de conta de água. Santo André, SP, 2008.

\begin{tabular}{|c|c|c|c|c|c|c|c|c|c|c|}
\hline \multirow[b]{3}{*}{$\begin{array}{l}\text { Recebe } \\
\text { conta de } \\
\text { água }\end{array}$} & \multicolumn{8}{|c|}{ GRUPO SOCIAL } & \multirow{2}{*}{\multicolumn{2}{|c|}{ Total }} \\
\hline & \multicolumn{2}{|c|}{ Central } & \multicolumn{2}{|c|}{ Quase Central } & \multicolumn{2}{|c|}{ Quase Periférico } & \multicolumn{2}{|c|}{ Periférico } & & \\
\hline & $\mathbf{N}$ & $\%$ & $\mathbf{N}$ & $\%$ & $\mathbf{N}$ & $\%$ & $\mathbf{N}$ & $\%$ & $\mathbf{N}$ & $\%$ \\
\hline Sim & 26 & 100,00 & 83 & 97,65 & 238 & 95,58 & 200 & 87,34 & 547 & 92,87 \\
\hline Não & 0 & 0,00 & 2 & 2,35 & 11 & 4,42 & 29 & 12,66 & 42 & 7,13 \\
\hline Total & 26 & 100,00 & 85 & 100,00 & 249 & 100,00 & 229 & 100,00 & 589 & 100,00 \\
\hline
\end{tabular}

Tabela 24 - Distribuição das famílias dos quatro grupos sociais segundo recebimento de conta de luz. Santo André, SP, 2008.

\begin{tabular}{|c|c|c|c|c|c|c|c|c|c|c|}
\hline \multirow[b]{3}{*}{$\begin{array}{l}\text { Recebe } \\
\text { conta de } \\
\text { luz }\end{array}$} & \multicolumn{8}{|c|}{ GRUPO SOCIAL } & \multirow{2}{*}{\multicolumn{2}{|c|}{ Total }} \\
\hline & \multicolumn{2}{|c|}{ Central } & \multicolumn{2}{|c|}{ Quase Central } & \multicolumn{2}{|c|}{ Quase Periférico } & \multicolumn{2}{|c|}{ Periférico } & & \\
\hline & $\mathbf{N}$ & $\%$ & $\mathbf{N}$ & $\%$ & $\mathbf{N}$ & $\%$ & $\mathbf{N}$ & $\%$ & $\mathbf{N}$ & $\%$ \\
\hline Sim & 26 & 100,00 & 84 & 98,82 & 241 & 96,79 & 207 & 90,39 & 558 & 94,74 \\
\hline Não & 0 & 0,00 & 1 & 1,18 & 8 & 3,21 & 22 & 9,61 & 31 & 5,26 \\
\hline Total & 26 & 100,00 & 85 & 100,00 & 249 & 100,00 & 229 & 100,00 & 589 & 100,00 \\
\hline
\end{tabular}


Tabela 25 - Distribuição das famílias dos quatro grupos sociais segundo destino do lixo. Santo André, SP, 2008.

\begin{tabular}{|c|c|c|c|c|c|c|c|c|c|c|}
\hline \multirow[b]{3}{*}{$\begin{array}{l}\text { Destino } \\
\text { do lixo }\end{array}$} & \multicolumn{8}{|c|}{ GRUPO SOCIAL } & \multirow{2}{*}{\multicolumn{2}{|c|}{ Total }} \\
\hline & \multicolumn{2}{|c|}{ Central } & \multicolumn{2}{|c|}{ Quase Central } & \multicolumn{2}{|c|}{ Quase Periférico } & \multicolumn{2}{|c|}{ Periférico } & & \\
\hline & $\mathbf{N}$ & $\%$ & $\mathbf{N}$ & $\%$ & $\mathbf{N}$ & $\%$ & $\mathbf{N}$ & $\%$ & $\mathbf{N}$ & $\%$ \\
\hline $\begin{array}{l}\text { Via } \\
\text { pública/ } \\
\text { terreno } \\
\text { baldio }\end{array}$ & 0 & 0,00 & 0 & 0,00 & 1 & 0,40 & 6 & 2,62 & 7 & 1,19 \\
\hline $\begin{array}{l}\text { Caminhão } \\
\text { de lixo }\end{array}$ & 25 & 96,15 & 85 & 100,00 & 247 & 99,20 & 221 & 96,51 & 578 & 98,13 \\
\hline Queima & 0 & 0,00 & 0 & 0,00 & 0 & 0,00 & 1 & 0,44 & 1 & 0,17 \\
\hline Outros & 0 & 0,00 & 0 & 0,00 & 0 & 0,00 & 1 & 0,44 & 1 & 0,17 \\
\hline $\begin{array}{l}\text { Sem } \\
\text { informaçã } \\
\text { o }\end{array}$ & 1 & 3,85 & 0 & 0,00 & 1 & 0,40 & 0 & 0,00 & 2 & 0,34 \\
\hline Total & 26 & 100,00 & 85 & 100,00 & 249 & 100,00 & 229 & 100,00 & 589 & 100,00 \\
\hline
\end{tabular}

Tabela 26 - Distribuição das famílias dos quatro grupos sociais segundo destino do esgoto. Santo André, SP, 2008.

\begin{tabular}{|c|c|c|c|c|c|c|c|c|c|c|}
\hline \multirow[b]{3}{*}{$\begin{array}{l}\text { Destino } \\
\text { esgoto }\end{array}$} & \multicolumn{8}{|c|}{ GRUPO SOCIAL } & \multirow{2}{*}{\multicolumn{2}{|c|}{ Total }} \\
\hline & \multicolumn{2}{|c|}{ Central } & \multicolumn{2}{|c|}{ Quase Central } & \multicolumn{2}{|c|}{ Quase Periférico } & \multicolumn{2}{|c|}{ Periférico } & & \\
\hline & $\mathbf{N}$ & $\%$ & $\mathbf{N}$ & $\%$ & $\mathbf{N}$ & $\%$ & $\mathbf{N}$ & $\%$ & $\mathbf{N}$ & $\%$ \\
\hline Fossa séptica & 0 & 0,00 & 0 & 0,00 & 5 & 2,01 & 52 & 22,71 & 57 & 9,68 \\
\hline Manancial & 0 & 0,00 & 0 & 0,00 & 2 & 0,80 & 5 & 2,18 & 7 & 1,19 \\
\hline Rio & 0 & 0,00 & 0 & 0,00 & 3 & 1,20 & 5 & 2,18 & 8 & 1,36 \\
\hline $\begin{array}{l}\text { Serviços } \\
\text { públicos }\end{array}$ & 26 & 100,00 & 84 & 98,82 & 237 & 95,18 & 165 & 72,05 & 512 & 86,93 \\
\hline Não sabe & 0 & 0,00 & 1 & 1,18 & 2 & 0,80 & 2 & 0,87 & 5 & 0,85 \\
\hline Total & 26 & 100,00 & 85 & 100,00 & 249 & 100,00 & 229 & 100,00 & 589 & 100,00 \\
\hline
\end{tabular}

No que diz respeito aos meios de transporte utilizados pelas famílias para irem à escola ou trabalho verificou-se que mais de $90 \%$ das famílias do grupo central utilizavam carro em contraposição às famílias do grupo periférico em que apenas um terço utilizava esse meio de locomoção. Ônibus foi o meio de transporte mais citado nas famílias dos grupos quase periférico e periférico, ressaltando-se que nesse item poderia ser dada mais de uma resposta (quadro 2). 
Quadro 2- Distribuição das famílias dos quatro grupos sociais segundo meio de transporte utilizado para ir ao trabalho/escola. Santo André, SP, 2008.

\begin{tabular}{|c|c|c|c|c|c|c|c|c|}
\hline \multirow[b]{3}{*}{ Meio de transporte } & \multicolumn{6}{|c|}{ GRUPO SOCIAL } & \multirow{2}{*}{\multicolumn{2}{|c|}{ Periférico }} \\
\hline & Cer & & Quase & entral & Quase I & riférico & & \\
\hline & $\mathbf{N}$ & $\%$ & $\mathbf{N}$ & $\%$ & $\mathbf{N}$ & $\%$ & $\mathbf{N}$ & $\%$ \\
\hline Total & 26 & 100,00 & 85 & 100,00 & 249 & 100,00 & 229 & 100,00 \\
\hline Trem & 6 & 23,08 & 12 & 14,12 & 58 & 23,29 & 33 & 14,41 \\
\hline Ônibus & 11 & 42,31 & 56 & 65,88 & 183 & 73,49 & 169 & 73,80 \\
\hline Automóvel & 24 & 92,31 & 53 & 62,35 & 133 & 53,41 & 78 & 34,06 \\
\hline Metrô & 5 & 19,23 & 7 & 8,24 & 38 & 15,26 & 26 & 11,35 \\
\hline Bicicleta & 1 & 3,85 & 3 & 3,53 & 33 & 13,25 & 25 & 10,92 \\
\hline Moto & 0 & 0,00 & 8 & 9,41 & 27 & 10,84 & 20 & 8,73 \\
\hline Fretado & 1 & 3,85 & 16 & 18,82 & 26 & 10,44 & 16 & 6,99 \\
\hline Perua escolar & 2 & 7,69 & 7 & 8,24 & 12 & 4,82 & 18 & 7,86 \\
\hline A pé & 17 & 65,38 & 46 & 54,12 & 176 & 70,68 & 172 & 75,11 \\
\hline Outros & 0 & 0,00 & 0 & 0,00 & 3 & 1,20 & 0 & 0,00 \\
\hline
\end{tabular}

Quanto às atividades de lazer das famílias verifica-se que a referência a atividades como ler, ir ao cinema e ao teatro, fazer viagens e utilizar a Internet diminuem nos grupos quase periférico e periférico enquanto que a freqüência a cultos é mais citada como forma de lazer por esses dois grupos. Ressalta-se a grande diferença entre os grupos central e periférico no que diz respeito a freqüentar teatro (Quadro 3).

Quadro 3 - Porcentual de famílias dos quatro grupos sociais segundo atividades de lazer. Santo André, SP, 2008.

\begin{tabular}{|lcccccccc|}
\hline & \multicolumn{9}{c}{ Central } & \multicolumn{2}{c|}{ Quase Central } & \multicolumn{2}{c|}{ Quase Periférico } & \multicolumn{2}{c|}{ Periférico } \\
Atividades de lazer da & $\mathbf{N}$ & $\mathbf{\%}$ & $\mathbf{N}$ & $\mathbf{\%}$ & $\mathbf{N}$ & $\mathbf{\%}$ & $\mathbf{N}$ & $\mathbf{\%}$ \\
família* & & & & & & & & \\
\hline Total & $\mathbf{2 6}$ & $\mathbf{1 0 0 , 0 0}$ & $\mathbf{8 5}$ & $\mathbf{1 0 0 , 0 0}$ & $\mathbf{2 4 9}$ & $\mathbf{1 0 0 , 0 0}$ & $\mathbf{2 2 9}$ & $\mathbf{1 0 0 , 0 0}$ \\
\hline Atividade física & 24 & 92,31 & 64 & 75,29 & 150 & 60,24 & 124 & 54,15 \\
Leitura & 21 & 80,77 & 70 & 82,35 & 172 & 69,08 & 150 & 65,50 \\
Tv/Vídeo & 25 & 96,15 & 82 & 96,47 & 241 & 96,79 & 219 & 95,63 \\
Cinema & 23 & 88,46 & 58 & 68,24 & 141 & 56,63 & 121 & 52,84 \\
Teatro & 15 & 57,69 & 27 & 31,76 & 53 & 21,29 & 41 & 17,90 \\
Viagem & 23 & 88,46 & 58 & 68,24 & 146 & 58,63 & 114 & 49,78 \\
Visitas a parques & 17 & 65,38 & 54 & 63,53 & 151 & 60,64 & 142 & 62,01 \\
Visitas a amigos e parentes & 21 & 80,77 & 73 & 85,88 & 210 & 84,34 & 190 & 82,97 \\
Festas & 23 & 88,46 & 76 & 89,41 & 205 & 82,33 & 178 & 77,73 \\
Internet & 24 & 92,31 & 76 & 89,41 & 190 & 76,31 & 156 & 68,12 \\
Cultos & 9 & 34,62 & 44 & 51,76 & 156 & 62,65 & 136 & 59,39 \\
Outros & 2 & 7,69 & 5 & 5,88 & 15 & 6,02 & 13 & 5,68 \\
\hline
\end{tabular}

* Cada família pode ter mais de uma atividade de lazer

Em relação aos riscos a que as famílias se sentem expostas verifica-se por meio do quadro 5 que houve um aumento significativo da proporção dos riscos de 
consumo de drogas e envolvimento com problemas decorrentes do tráfico de drogas conforme a exclusão dos grupos aumenta $(\mathrm{p}=0,001$ e $\mathrm{p}=0,041$ respectivamente), evidenciando dependência entre essas variáveis e os grupos sociais. Ressalta-se a disparidade da percepção do risco do envolvimento com problemas decorrentes do tráfico de drogas pelo grupo central. Riscos decorrentes da falta de saneamento como contaminação por lixo ou córregos e contato com vetores foram bem significativos nos grupos quase periférico e periférico ( $\mathrm{p}=0,00$ para as duas variáveis).

Quadro 4- Porcentual de famílias que declararam estar expostas a algum tipo de risco. Santo André, SP, 2008.

\begin{tabular}{|c|c|c|c|c|c|c|c|c|}
\hline \multirow{3}{*}{$\begin{array}{l}\text { Riscos a que se sentem } \\
\text { expostos }\end{array}$} & \multicolumn{6}{|c|}{ GRUPO SOCIAL } & \multirow{2}{*}{\multicolumn{2}{|c|}{ Periférico }} \\
\hline & \multicolumn{2}{|c|}{ Central } & \multicolumn{2}{|c|}{ Quase Central } & \multicolumn{2}{|c|}{ Quase Periférico } & & \\
\hline & $\mathbf{N}$ & $\%$ & $\mathbf{N}$ & $\%$ & $\mathbf{N}$ & $\%$ & $\mathbf{N}$ & $\%$ \\
\hline Total & 26 & 100,00 & 85 & 100,00 & 249 & 100,00 & 229 & 100,00 \\
\hline Desmoronamento & 0 & 0,00 & 2 & 2,35 & 12 & 4,82 & 21 & 9,17 \\
\hline Enchente & 1 & 3,85 & 2 & 2,35 & 6 & 2,41 & 11 & 4,80 \\
\hline Violência & 14 & 53,85 & 56 & 65,88 & 170 & 68,27 & 130 & 56,77 \\
\hline Acidente de trânsito & 10 & 38,46 & 36 & 42,35 & 101 & 40,56 & 75 & 32,75 \\
\hline $\begin{array}{l}\text { Contaminação (lixo, } \\
\text { esgoto, córregos) }\end{array}$ & 1 & 3,85 & 7 & 8,24 & 28 & 11,24 & 60 & 26,20 \\
\hline $\begin{array}{l}\text { Contato com vetores (ratos } \\
\text { e insetos) }\end{array}$ & 5 & 19,23 & 28 & 32,94 & 119 & 47,79 & 111 & 48,47 \\
\hline $\begin{array}{l}\text { Risco de consumo de } \\
\text { drogas (inclusive } \\
\text { alcoolismo) }\end{array}$ & 9 & 34,62 & 39 & 45,88 & 126 & 50,60 & 146 & 63,76 \\
\hline $\begin{array}{l}\text { Envolvimento com } \\
\text { problemas decorrentes do } \\
\text { tráfico de drogas }\end{array}$ & 2 & 7,69 & 20 & 23,53 & 60 & 24,10 & 71 & 31,00 \\
\hline Outros & 0 & 0,00 & 0 & 0,00 & 8 & 3,21 & 9 & 3,93 \\
\hline
\end{tabular}

Ao avaliar rede de apoio social identificou-se a participação social das famílias dos quatro grupos é pequena e concentra-se principalmente em atividades ligadas à igreja principalmente nos grupos central e quase periférico, excluindo-se frequiência a cultos ou missas (quadro 5). Referências à participação em conselhos de bairro, partido político, ONG's e voluntariado não foram significativas.

Quadro 5- Percentual de famílias dos quatro grupos sociais que relataram alguma forma de participação social. Santo André, SP, 2008.

\begin{tabular}{|c|c|c|c|c|c|c|c|c|}
\hline \multirow[b]{3}{*}{ Participação social } & \multicolumn{6}{|c|}{ GRUPO SOCIAL } & \multirow{2}{*}{\multicolumn{2}{|c|}{ Periférico }} \\
\hline & \multicolumn{2}{|c|}{ Central } & \multicolumn{2}{|c|}{ Quase Central } & \multicolumn{2}{|c|}{ Quase Periférico } & & \\
\hline & $\mathbf{N}$ & $\%$ & $\mathbf{N}$ & $\%$ & $\mathbf{N}$ & $\%$ & $\mathbf{N}$ & $\%$ \\
\hline Total & 26 & 100,00 & 85 & 100,00 & 249 & 100,00 & 229 & 100,00 \\
\hline Escola & & 3,85 & 1 & 1,18 & 13 & 5,22 & 12 & 5,24 \\
\hline Sindicato/Associação & & 3,85 & 8 & 9,41 & 20 & 8,03 & 12 & 5,24 \\
\hline Ligadas à religião & & 15,38 & 10 & 11,76 & 45 & 18,07 & 31 & 13,54 \\
\hline
\end{tabular}


Quanto à suficiência ou não de renda para gastos de alimentação e vestuário é interessante notar que nos quatro grupos a renda foi referida como suficiente (tabela 27), entretanto quase um terço das famílias do grupo central relataram conseguir guardar dinheiro justificando o fato de que mais da metade desse grupo consegue realizar aplicações ou fazer poupança (tabela 28) e que apenas $10 \%$ dessas famílias tenham dívidas em contraposição aos grupos quase periférico e periférico. Chama a atenção que a proporção de famílias do grupo quase periférico que tem dívidas que não consegue pagar é maior que a do grupo periférico (tabela 29). Por outro lado, é interessante notar que quando se trata de dívidas a respeito de crediários e empréstimos aparentemente não se verifica diferenças entre os quatro grupos sociais (tabela 30).

Tabela 27- Distribuição das famílias dos quatro grupos sociais segundo suficiência da renda para arcar com despesas básicas (alimentação, vestuário, contas de água e de luz). Santo André, SP, 2008.

\begin{tabular}{|c|c|c|c|c|c|c|c|c|c|c|c|}
\hline \multirow{3}{*}{\multicolumn{2}{|c|}{ Renda da família }} & \multicolumn{8}{|c|}{ GRUPO SOCIAL } & \multirow{2}{*}{\multicolumn{2}{|c|}{ Total }} \\
\hline & & \multicolumn{2}{|c|}{ Central } & \multicolumn{2}{|c|}{ Quase Central } & \multicolumn{2}{|c|}{$\begin{array}{c}\text { Quase } \\
\text { Periférico }\end{array}$} & \multicolumn{2}{|c|}{ Periférico } & & \\
\hline & & $\mathbf{N}$ & $\%$ & $\mathbf{N}$ & $\%$ & $\mathbf{N}$ & $\%$ & $\mathbf{N}$ & $\%$ & $\mathbf{N}$ & $\%$ \\
\hline Suficiente & & 12 & 46,15 & 39 & 45,88 & 114 & 45,78 & 96 & 41,92 & 261 & 44,31 \\
\hline Insuficiente & & 6 & 23,08 & 24 & 28,24 & 105 & 42,17 & 104 & 45,41 & 239 & 40,58 \\
\hline $\begin{array}{l}\text { Suficiente } \\
\text { sobra } \\
\text { guardar }\end{array}$ & $\begin{array}{r}\text { e } \\
\text { para }\end{array}$ & 8 & 30,77 & 22 & 25,88 & 30 & 12,05 & 29 & 12,66 & 89 & 15,11 \\
\hline Total & & 26 & 100,00 & 85 & 100,00 & 249 & 100,00 & 229 & 100,00 & 589 & 100,00 \\
\hline
\end{tabular}

Tabela 28- Distribuição das famílias dos quatro grupos sociais segundo posse de poupança ou aplicações financeiras. Santo André, SP, 2008.

\begin{tabular}{|c|c|c|c|c|c|c|c|c|c|c|}
\hline \multirow[b]{3}{*}{$\begin{array}{l}\text { Poupança } \\
\text { ou } \\
\text { aplicações }\end{array}$} & \multicolumn{8}{|c|}{ GRUPO SOCIAL } & \multirow{2}{*}{\multicolumn{2}{|c|}{ Total }} \\
\hline & \multicolumn{2}{|c|}{ Central } & \multirow{2}{*}{$\begin{array}{l}\text { Quase } \\
\mathbf{N}\end{array}$} & \multirow{2}{*}{$\begin{array}{c}\text { entral } \\
\%\end{array}$} & \multicolumn{2}{|c|}{ Quase Periférico } & \multicolumn{2}{|c|}{ Periférico } & & \\
\hline & $\mathbf{N}$ & $\%$ & & & $\mathbf{N}$ & $\%$ & $\mathbf{N}$ & $\%$ & \multicolumn{2}{|c|}{ N $\%$} \\
\hline Sim & 16 & 61,54 & 34 & 40,00 & 97 & 38,96 & 77 & 33,62 & 224 & 38,03 \\
\hline Não & 10 & 38,46 & 47 & 55,29 & 148 & 59,44 & 146 & 63,76 & 351 & 59,59 \\
\hline Não sabe & 0 & 0,00 & 4 & 4,71 & 4 & 1,61 & 6 & 2,62 & 14 & 2,38 \\
\hline Total & 26 & 100,00 & 85 & 100,00 & 249 & 100,00 & 229 & 100,00 & 589 & 100,00 \\
\hline
\end{tabular}


Tabela 29- Distribuição das famílias dos quatro grupos sociais segundo referências a dívidas que não conseguem pagar. Santo André, SP, 2008.

\begin{tabular}{|c|c|c|c|c|c|c|c|c|c|c|}
\hline \multirow[b]{2}{*}{$\begin{array}{l}\text { Nome no } \\
\text { Serasa e } \\
\text { dívidas }\end{array}$} & \multicolumn{8}{|c|}{ GRUPO SOCIAL } & \multirow[b]{2}{*}{$\mathbf{N}$} & \multirow[b]{2}{*}{$\%$} \\
\hline & $\mathbf{N}$ & $\%$ & $\mathbf{N}$ & $\%$ & $\mathbf{N}$ & $\%$ & $\mathbf{N}$ & $\%$ & & \\
\hline Sim & 3 & 11,54 & 17 & 20,00 & 63 & 25,30 & 88 & 38,43 & 171 & 29,03 \\
\hline Não & 23 & 88,46 & 66 & 77,65 & 185 & 74,30 & 139 & 60,70 & 413 & 70,12 \\
\hline Não sabe & 0 & 0,00 & 2 & 2,35 & 1 & 0,40 & 2 & 0,87 & 5 & 0,85 \\
\hline Total & 26 & 100,00 & 85 & 100,00 & 249 & 100,00 & 229 & 100,00 & 589 & 100,00 \\
\hline
\end{tabular}

Tabela 30- Distribuição das famílias dos quatro grupos sociais segundo gastos com crediários ou empréstimos. Santo André, SP, 2008.

\section{GRUPO SOCIAL}

\begin{tabular}{lrrrrrrrrrr}
$\begin{array}{l}\text { Gastos } \\
\text { com } \\
\text { crediários }\end{array}$ & $\mathbf{N}$ & \multicolumn{1}{l}{$\mathbf{N}$} & $\mathbf{N}$ & $\mathbf{N}$ & $\boldsymbol{\%}$ & $\mathbf{N}$ & $\boldsymbol{\%}$ & $\mathbf{N}$ & $\boldsymbol{\%}$ \\
\hline Sim & 11 & 42,31 & 31 & 36,47 & 100 & 40,16 & 121 & 52,84 & 263 & 44,65 \\
Não & 14 & 53,85 & 52 & 61,18 & 148 & 59,44 & 108 & 47,16 & 322 & 54,67 \\
Não sabe & 1 & 3,85 & 2 & 2,35 & 1 & 0,40 & 0 & 0,00 & 4 & 0,68 \\
Total & $\mathbf{2 6}$ & $\mathbf{1 0 0 , 0 0}$ & $\mathbf{8 5}$ & $\mathbf{1 0 0 , 0 0}$ & $\mathbf{2 4 9}$ & $\mathbf{1 0 0 , 0 0}$ & $\mathbf{2 2 9}$ & $\mathbf{1 0 0 , 0 0}$ & $\mathbf{5 8 9}$ & $\mathbf{1 0 0 , 0 0}$ \\
\hline
\end{tabular}


ANEXO V 


\section{ANEXO V \\ COMPORTAMENTO DAS VARIÁVEIS CONSIDERANDO OS CHEFES DE FAMÍLIA NÃO DIVIDIDOS EM GRUPOS}

Quanto à escolaridade verificou-se que quase um terço dos chefes apresentavam ensino médio completo (tabela 1)

Tabela 1 - Distribuição dos chefes de família segundo escolaridade. Santo André, SP, 2008.

\begin{tabular}{|c|c|c|}
\hline Escolaridade & $\mathbf{N}$ & $\%$ \\
\hline EF incompleto & 147 & 25,0 \\
\hline EF completo/Médio Incompl & 121 & 20,5 \\
\hline EM Completo & 186 & 31,6 \\
\hline Superior incompl/ completo & 86 & 14,6 \\
\hline Pós-graduação & 18 & 3,1 \\
\hline Supletivo EF/EM & 14 & 2,4 \\
\hline Sabe Ler/Escrever/Analfabeto & 13 & 2,2 \\
\hline Sem informação & 4 & ,7 \\
\hline Total & 589 & 100,0 \\
\hline
\end{tabular}

No que diz respeito aos chefes que realizaram ou estavam realizando algum curso preparatório para o trabalho verificou-se que $31,2 \%$ dos chefes realizaram e que $0,8 \%$ estavam cursando.

Quanto à condição de atividade, verificou-se que mais da metade dos chefes de família eram trabalhadores assalariados. Chama a atenção o fato de que quase $10 \%$ dos chefes eram aposentados (tabela 2).

Tabela 2 - Distribuição dos chefes de família segundo condição de atividade. Santo André, SP, 2008.

\begin{tabular}{|c|c|c|}
\hline Condição de atividade & $\mathbf{N}$ & $\%$ \\
\hline Aposentado & 58 & 9,8 \\
\hline Desempregado & 20 & 3,4 \\
\hline Trabalho assalariado & 349 & 59,3 \\
\hline Autônomo & 93 & 15,8 \\
\hline Bico & 14 & 2,4 \\
\hline Pensionista & 14 & 2,4 \\
\hline Empregador & 15 & 2,5 \\
\hline Trab familiar & 7 & 1,2 \\
\hline Dona de casa & 12 & 2,0 \\
\hline Não inserido & 1 & 0,2 \\
\hline Afastado do trabalho & 6 & 1,0 \\
\hline Total & 589 & 100,0 \\
\hline
\end{tabular}


A seguir verificou-se os locais de trabalho dos chefes de família ressaltando-se que a grande maioria trabalhava no setor de serviços. Ressalta-se que cerca de $20 \%$ dos chefes trabalhava em fábricas.

Tabela 3 - Distribuição dos chefes de família segundo local de trabalho. Santo André, SP, 2008 .

\begin{tabular}{|c|c|c|}
\hline Local de trabalho & $\mathbf{N}$ & $\%$ \\
\hline Fábrica & 106 & 18,0 \\
\hline Posto de Gasolina/Lava-Rápido/Estacionamento & 3 & 0,5 \\
\hline Construção & 24 & 4,1 \\
\hline Bar/Pizzaria/Lanchonete & 14 & 2,4 \\
\hline Loja & 26 & 4,4 \\
\hline Repartição pública & 18 & 3,1 \\
\hline Casas particulares (empregados domésticos) & 37 & 6,3 \\
\hline Ônibus/Caminhão/Táxi/moto & 32 & 5,4 \\
\hline Empresa & 35 & 5,9 \\
\hline Oficina/Ateliê/serralheria & 19 & 3,2 \\
\hline Escola/Faculdade & 20 & 3,4 \\
\hline Hospital/Clínica/UBS/Laboratório & 19 & 3,2 \\
\hline Prédio (portaria) & 10 & 1,7 \\
\hline Clube & 4 & 0,7 \\
\hline FEBEM & 1 & 0,2 \\
\hline Na própria casa & 22 & 3,7 \\
\hline Banco & 6 & 1,0 \\
\hline Escritório & 28 & 4,8 \\
\hline Feira & 6 & 1,0 \\
\hline Açougue/padaria/supermercado & 13 & 2,2 \\
\hline Rua & 25 & 4,2 \\
\hline Salão de beleza & 1 & 0,2 \\
\hline Cemitério & 1 & 0,2 \\
\hline Hotel/Buffett & 2 & 0,3 \\
\hline Outros & 4 & 0,7 \\
\hline $\begin{array}{l}\text { Não se aplica (desempregados, pensionistas, donas de casa, não inseridos, } \\
\text { afastados do trabalho, aposentados que não trabalham- 36) }\end{array}$ & 89 & 15,7 \\
\hline Sem informação & 24 & 4,1 \\
\hline Total & 589 & 100,0 \\
\hline
\end{tabular}

Quanto à qualificação dos chefes de trabalho ativos identificou-se que quase um terço deles trabalhava em atividades de execução semi-qualificadas. Ressalta-se que as ocupações mais qualificadas de planejamento, organização direção e gerência somavam $16,1 \%$ quase equiparando-se à soma das menos qualificadas (serviços gerais e não qualificados na execução) que juntas representaram 13,1\% (Tabela 4). 
Destes trabalhadores, $419(71,1 \%)$ trabalhavam no setor privado e $57(9,7 \%)$ no setor público.

Tabela 4 - Distribuição dos chefes de família segundo qualificação da ocupação. Santo André, SP, 2008.

\begin{tabular}{|c|c|c|}
\hline Qualificação das ocupações & $\mathbf{N}$ & $\%$ \\
\hline Planejamento e Organização & 42 & 7,1 \\
\hline Empresário, direção e gerência & 53 & 9,0 \\
\hline Não qualificado na execução & 56 & 9,5 \\
\hline Semi-qualificado na execução & 175 & 29,7 \\
\hline Qualificado na execução & 40 & 6,8 \\
\hline Serviços gerais & 21 & 3,6 \\
\hline Serviços de escritório & 9 & 1,5 \\
\hline Não operacional/apoio & 30 & 5,1 \\
\hline Mal definidas & 50 & 8,5 \\
\hline Não se aplica & 89 & 15,1 \\
\hline Sem informação & 24 & 4,1 \\
\hline Total & \multicolumn{2}{|c|}{589} \\
\hline
\end{tabular}

No que diz respeito à renda, 280 (47,5\%) famílias recebiam até um salário mínimo per capita e que $183(31,1 \%)$ recebiam de 1 a 2 salários mínimos. Ressalta-se que o cálculo foi feito com toda a renda da família e não apenas com a recebida pelo chefe de família.

Tabela 5 - Distribuição das famílias segundo faixa de renda per capita em salários mínimos. Santo André, SP, 2008.

\begin{tabular}{lcc}
\hline Faixa de renda per capita em salários mínimos & N & \% \\
\hline Até 1 s.m. & 280 & 47,5 \\
De 1 a 2 sm. & 183 & 31,1 \\
De 2 a 3 sm. & 66 & 11,2 \\
De 3 a 5 sm. & 34 & 5,8 \\
De 5 sm. ou mais & 24 & 4,1 \\
Sem informação & 2 & 0,3 \\
Total & $\mathbf{5 8 9}$ & $\mathbf{1 0 0 , 0}$ \\
\hline
\end{tabular}

Quanto às rendas provenientes de outras fontes que não o trabalho principal verificou-se que apenas $52(8,8 \%)$ chefes de famílias as recebiam, sendo que em 23 casos estas diziam respeito a alugueis, 3 estavam relacionados a seguro-desemprego ,7 auxílio INSS e 19 outras fontes como por exemplo venda de produtos cosméticos ou costura.

No que diz respeito ao registro em carteira verifica-se que mais da metade dos trabalhadores $(51,1 \%)$ a possuem (tabela 6$)$. 
Tabela 6 - Distribuição dos chefes de família segundo posse de registro em carteira. Santo André, SP, 2008.

\begin{tabular}{lcc}
\hline Tem registro em carteira? & $\mathbf{N}$ & $\mathbf{\%}$ \\
\hline Sim & 301 & 51,1 \\
Não & 174 & 29,5 \\
Não se aplica & 89 & 15,1 \\
Sem informação & 25 & 4,2 \\
\hline Total & $\mathbf{5 8 9}$ & $\mathbf{1 0 0 , 0}$ \\
\hline
\end{tabular}

Em relação aos benefícios oriundos do trabalho identificou-se que o vale transporte, assistência médica e vale refeição foram os mais citados. Ressalta-se que $28,2 \%$ dos chefes não recebem nenhum benefício (Quadro 1).

Quadro 1 - Distribuição dos chefes de família segundo posse de benefícios oriundos do trabalho. Santo André, SP, 2008.

\begin{tabular}{|lrr|}
\hline $\begin{array}{l}\text { Recebe beneficio } \\
\text { oriundo do trabalho? }\end{array}$ & N & \multicolumn{1}{c|}{$\%$} \\
Cesta básica & 89 & 15,1 \\
Vale refeição & 123 & 20,9 \\
Vale Supermercado & 27 & 4,6 \\
Ass.Médica & 155 & 26,3 \\
Assistência Odontológica & 30 & 5,1 \\
Vale transporte & 166 & 28,2 \\
Outros & 4 & 0,7 \\
Não recebe & 193 & 32,8 \\
\hline
\end{tabular}

Ao se verificar o tempo dos chefes de família no mesmo emprego, identificou-se que 20,5\% (121) deles estavam há mais de 16 anos no mesmo emprego e $354(60,1 \%)$ estavam há menos tempo. Ressalta-se que em 4,2\% dos casos não se tinha informação e que em $15,1 \%$ esse dado não se aplicava.

Quanto às horas semanais trabalhadas identificou-se que $15,4 \%$ dos chefes trabalhavam mais de 50 horas semanais e que os demais chefes sobre os quais foi obtida essa informação $(65,19 \%)$ trabalhavam menos que esse período.

Em relação ao tempo despendido para ir e voltar do trabalho verificou-se que a maior parte dos chefes de família trabalha relativamente próximos à sua casa já que $42 \%$ deles gastam até uma hora para ir e voltar do trabalho (Tabela 7).

Para ir e voltar do trabalho/escola verificou-se que a maior parte das famílias utiliza o ônibus ou caminha. Ressalta-se que quase metade das famílias utiliza o automóvel como meio de transporte como pode ser visto no quadro 2 . 
Tabela 7 - Distribuição dos chefes das famílias segundo tempo gasto para ir e voltar do trabalho. Santo André, SP, 2008.

\begin{tabular}{lrr}
\hline Tempo gasto & N & \multicolumn{2}{c}{$\%$} \\
\hline Trabalha em casa & 39 & 6,6 \\
De 1 a 20 minutos & 78 & 13,2 \\
De 21 a 40 minutos & 91 & 14,4 \\
De 41 a 60 minutos & 79 & 13,4 \\
De 61 a 90 minutos & 53 & 9,0 \\
De 91 a 120 minutos & 75 & 12,7 \\
Mais de 120 minutos & 60 & 10,2 \\
Não se aplica & 89 & 15,1 \\
Sem informação & 25 & 4,2 \\
\hline Total & $\mathbf{5 8 9}$ & $\mathbf{1 0 0 , 0}$ \\
\hline
\end{tabular}

Quadro 2- Distribuição das famílias dos quatro grupos sociais segundo meio de transporte utilizado para ir ao trabalho/escola. Santo André, SP, 2008.

\begin{tabular}{|l|rc|}
\hline Meio de transporte & N & \% \\
\hline Ônibus & 419 & 71,1 \\
A pé & 411 & 69,8 \\
Automóvel & 288 & 48,9 \\
Trem & 109 & 18,5 \\
Metrô & 76 & 12,9 \\
Bicicleta & 62 & 10,5 \\
Fretado & 59 & 10,0 \\
Moto & 55 & 9,3 \\
Perua escolar & 39 & 6,6 \\
\hline Outros & 3 & 0,5 \\
\hline
\end{tabular}

Dimensão do consumo- formas de viver

Em relação às características da habitação identificou-se que a maior parte das casas $(85,9 \%)$ era de alvenaria com acabamento e que se configuravam em casa ou apartamento (Tabelas 8 e 9). Mais da metade $(62,8 \%)$ eram casa próprias em situação regular de documentação (tabela 10). 
Tabela 8 - Distribuição das famílias segundo material da habitação. Santo André, SP, 2008.

\begin{tabular}{lcc}
\hline Material da habitação & $\mathbf{N}$ & $\mathbf{\%}$ \\
\hline Alvenaria com acabamento & 506 & 85,9 \\
Alvenaria sem acabamento & 75 & 12,7 \\
Madeira & 6 & 1,0 \\
Material aproveitado (papelão, plástico) & 2 & 0,3 \\
Total & $\mathbf{5 8 9}$ & $\mathbf{1 0 0 , 0 0}$ \\
\hline
\end{tabular}

Tabela 9- Distribuição das famílias segundo localização da moradia. Santo André, SP, 2008.

\begin{tabular}{lrr}
\hline Localização moradia & N & \multicolumn{1}{c}{$\%$} \\
\hline Casa/apto & 497 & 84,4 \\
Favela/ Quintal comum & 79 & 13,4 \\
CDHU, COHAB & 9 & 1,5 \\
Cortiço & 4 & 0,7 \\
Total & $\mathbf{5 8 9}$ & $\mathbf{1 0 0 , 0 0}$ \\
\hline
\end{tabular}

Tabela 10 - Distribuição das famílias segundo propriedade da residência. Santo André, SP, 2008.

\begin{tabular}{lrr}
\hline Propriedade da residência & N & \multicolumn{1}{c}{$\%$} \\
\hline Própria regular & 369 & 62,8 \\
Alugada & 109 & 18,5 \\
Cedida & 60 & 10,2 \\
Própria irregular & 39 & 6,6 \\
Financiada & 10 & 1,7 \\
Outro & 1 & 0,2 \\
Total & $\mathbf{5 8 9}$ & $\mathbf{1 0 0 , 0 0}$ \\
\hline
\end{tabular}

Ressalta-se que do total de 568 famílias as quais se tinha informação, 122 $(21,5 \%)$ estavam isentos de pagar IPTU

Verificou-se que 178 (30,2\%) famílias mudaram de casa nos últimos cinco anos, sendo que as principais causas foram: melhora de condições financeiras, mudança por casamento ou separação e melhora de infraestrutura (Tabela 11). 
Tabela 11 - Distribuição das famílias segundo motivo de mudança nos últimos cinco anos. Santo André, SP, 2008.

\begin{tabular}{lrr}
\hline Motivos de mudança & N & \multicolumn{1}{c}{$\%$} \\
\hline Melhora de condições financeiras & 46 & 25,70 \\
Casamento/ & 36 & 20,11 \\
Separação & & \\
Melhora da Infra-estrutura & 35 & 19,55 \\
Outro & 21 & 12,85 \\
Piora das condições financeiras & 19 & 10,61 \\
Transferência de emprego & 14 & 7,82 \\
Segurança & 4 & 2,23 \\
Transferência de escola & 1 & 0,56 \\
Não Sabe & 1 & 0,56 \\
Total & $\mathbf{1 7 7}$ & $\mathbf{1 0 0 , 0 0}$ \\
\hline
\end{tabular}

Quanto à posse de bens e serviços verificou-se que a maior parte das famílias tinham 1 ou 2 rádios, televisões e aparelhos de DVD, bem como máquina de lavar e 1 ou 2 banheiros. A grande maioria das famílias tinha mais de um cômodo para dormir, mas não tinha empregados mensalistas e nem freezer. Mais da metade tinha automóvel, aspirador de pó, computador e computador com acesso à internet (quadro $3)$. 
Quadro 3 - Percentual de famílias que possuem bens eletrodomésticos e acesso a serviços. Santo André, SP, 2008.

\begin{tabular}{|c|c|c|}
\hline Bens & $\mathbf{N}$ & $\%$ \\
\hline \multicolumn{3}{|c|}{ Rádio/aparelho de Som } \\
\hline Não tem & 47 & 8,0 \\
\hline 1 ou 2 & 447 & 75,9 \\
\hline 3 ou mais & 95 & 16,1 \\
\hline \multicolumn{3}{|l|}{ TV } \\
\hline Não tem & 5 & 8 \\
\hline 1 ou 2 & 397 & 67,4 \\
\hline 3 ou mais & 187 & 31,7 \\
\hline \multicolumn{3}{|l|}{ Banheiro } \\
\hline Não tem & 1 & 0,2 \\
\hline 1 ou 2 & 510 & 86,6 \\
\hline 3 ou mais & 78 & 13,2 \\
\hline \multicolumn{3}{|c|}{ Automóvel } \\
\hline Não tem & 237 & 40,2 \\
\hline 1 ou 2 & 323 & 54,8 \\
\hline 3 ou mais & 29 & 4,9 \\
\hline \multicolumn{3}{|c|}{ Aspirador de pó } \\
\hline Não & 342 & 58,1 \\
\hline Sim & 247 & 41,9 \\
\hline \multicolumn{3}{|c|}{ Máquina de lavar roupa } \\
\hline Não & 75 & 12,7 \\
\hline Sim & 514 & 87,3 \\
\hline \multicolumn{3}{|c|}{ Vídeo/DVD } \\
\hline Não tem & 52 & 8,8 \\
\hline 1 ou 2 & 504 & 85,6 \\
\hline 3 ou mais & 33 & 5,6 \\
\hline \multicolumn{3}{|l|}{ Geladeira } \\
\hline Não & 210 & 35,7 \\
\hline Sim & 379 & 64,3 \\
\hline \multicolumn{3}{|c|}{ Geladeira duplex } \\
\hline Não & 365 & 61,9 \\
\hline Sim & 224 & 38,1 \\
\hline \multicolumn{3}{|l|}{ Freezer } \\
\hline Não & 475 & 80,6 \\
\hline Sim & 114 & 19,4 \\
\hline \multicolumn{3}{|c|}{ Computador } \\
\hline Não & 185 & 31,4 \\
\hline Sim & 404 & 68,6 \\
\hline \multicolumn{3}{|c|}{ Computador com internet } \\
\hline Não & 242 & 41,1 \\
\hline Sim & 347 & 58,9 \\
\hline \multicolumn{3}{|c|}{ Cômodos para dormir } \\
\hline 1 & 100 & 17,0 \\
\hline 2 & 264 & 44,9 \\
\hline 3 & 187 & 31,6 \\
\hline 4 ou mais & 38 & 6,5 \\
\hline \multicolumn{3}{|c|}{ Empregados mensalistas } \\
\hline Não & 545 & 92,6 \\
\hline Sim & 44 & 7,5 \\
\hline
\end{tabular}


No que diz respeito ao acesso aos serviços de saneamento básico, identificou-se que a quase totalidade das famílias tinham acesso à água, luz e coleta de lixo $(97,1 \%, 98,1 \% \mathrm{e}$ $98,3 \%$ respectivamente). Em relação ao acesso a esgoto, a porcentagem cai para $87,1 \%$ ressaltando que há uma grande área de manancial próximo à região de Paranapiacaba.. Quando se verificou a legalidade do acesso à água e luz observou-se que 92,9\% das famílias pagavam conta de água e $94,7 \&$ pagavam conta de luz.

Em relação ao destino do lixo verificou-se que a quase totalidade das famílias tinham acesso à coleta por caminhões de lixo (Tabela 12) e a grande maioria tinha acesso a serviços públicos de esgoto (tabela 13).

Tabela 12 - Distribuição das famílias segundo destino do lixo. Santo André, SP, 2008.

\begin{tabular}{lrr} 
Destino do lixo & N & \multicolumn{1}{c}{$\%$} \\
\hline Caminhão de lixo & 578 & 98,13 \\
Via pública/ terreno baldio & 7 & 1,19 \\
Sem informação & 2 & 0,34 \\
Queima & 1 & 0,17 \\
Outros & 1 & 0,17 \\
Total & 589 & 100,00 \\
\hline
\end{tabular}

Tabela 13 - Distribuição das famílias segundo destino do esgoto. Santo André, SP, 2008.

\begin{tabular}{lcc} 
Destino do esgoto & N & \% \\
\hline Serviços públicos & 512 & 86,93 \\
Fossa séptica & 57 & 9,68 \\
Rio & 8 & 1,36 \\
Manancial & 7 & 1,19 \\
Não sabe & 5 & 0,85 \\
Total & 589 & 100,00 \\
\hline
\end{tabular}

Quanto a benefícios da sociedade civil verificou-se que a quase totalidade das famílias não recebem sendo que o bolsa família contemplava 1,4\% das famílias (Tabela 14).

Tabela 14- Distribuição das famílias segundo acesso a benefícios do governo. Santo André, SP, 2008

\begin{tabular}{lrr}
\hline $\begin{array}{l}\text { Benefícios do } \\
\text { governo }\end{array}$ & N & \multicolumn{1}{c}{$\%$} \\
\hline Bolsa família & 8 & 1,4 \\
Banco do povo & 1 & 0,2 \\
Não recebe & 575 & 97,6 \\
Outros & 5 & 0,8 \\
\hline Total & $\mathbf{5 8 9}$ & $\mathbf{1 0 0 , 0}$ \\
\hline
\end{tabular}


No que diz respeito aos meios de transporte utilizados pelas famílias para irem à escola ou trabalho verificou-se que a maior parte das famílias utiliza ônibus ou caminha.

Quanto às atividades de lazer das famílias verifica-se que o teatro foi citado por poucas famílias. Também chama a atenção que mais da metade das famílias citou os cultos como forma de lazer quase na mesma proporção do cinema e das viagens. (Quadro 4).

Quadro 4- Porcentual de famílias dos quatro grupos sociais segundo atividades de lazer. Santo André, SP, 2008.

\begin{tabular}{|lrr|}
\hline & & \\
Atividades de lazer da família* & N & \% \\
\hline Tv/Vídeo & 567 & 96,3 \\
Visitas a amigos e parentes & 494 & 83,9 \\
Festas & 482 & 81,8 \\
Internet & 446 & 75,7 \\
Leitura & 413 & 70,1 \\
Visitas a parques & 364 & 61,8 \\
Atividade física & 362 & 61,5 \\
Cultos & 345 & 58,6 \\
Cinema & 343 & 58,2 \\
Viagem & 341 & 57,9 \\
Teatro & 136 & 23,1 \\
Outros & 35 & 5,9 \\
\hline
\end{tabular}

*Cada família pode ter mais de uma atividade de lazer

Em relação aos riscos a que as famílias se sentem expostas verifica-se por meio do quadro 5 que a violência de forma geral foi a mais citada seguida pelo risco de consumo de drogas e contato com vetores (ratos e insetos).

Quadro 5 - Porcentual de famílias que declararam estar expostas a algum tipo de risco. Santo André, SP, 2008.

\begin{tabular}{|lcr|}
\hline Riscos a que se sentem expostos & N & \% \\
\hline Violência & 370 & 62,8 \\
Risco de consumo de drogas (inclusive alcoolismo) & 320 & 54,3 \\
Contato com vetores (ratos e insetos) & 263 & 44,7 \\
Acidente de trânsito & 222 & 37,7 \\
Envolvimento com problemas decorrentes do tráfico de & 153 & 26,0 \\
drogas & & \\
Contaminação (lixo, esgoto, córregos) & 96 & 16,3 \\
Desmoronamento & 35 & 5,9 \\
Enchente & 20 & 3,4 \\
Outros & 17 & 2,9 \\
\hline
\end{tabular}

Ao avaliar rede de apoio social identificou-se a participação social das famílias se restringe a aproximadamente um quarto das famílias (169 - 28,7\%), concretizada principalmente em atividades ligadas à escola (27-4,6\%), ao sindicato ou associações ligadas ao trabalho $(41-7,0 \%)$ e à religião $(90-15,3 \%)$. Referências à participação em 
conselhos de bairro, partido político, ONG's e voluntariado não foram significativas (Quadro 6)

Quadro 6- Distribuição das famílias segundo participação social. Santo André, SP, 2008

\begin{tabular}{|c|c|c|}
\hline Participação & $\mathbf{N}$ & $\%$ \\
\hline No bairro & 13 & 2,2 \\
\hline Conselhos de saúde & 6 & 1,0 \\
\hline Escola & 27 & 4,6 \\
\hline Trabalho & 6 & 1,0 \\
\hline Sindicato/associação & 41 & 7,0 \\
\hline Igreja & 90 & 15,3 \\
\hline Partido político & 12 & 2,0 \\
\hline Ligado a ONG & 3 & 0,5 \\
\hline $\begin{array}{l}\text { Ligado a outro tipo de } \\
\text { agrupamento }\end{array}$ & 3 & 0,5 \\
\hline Voluntariado & 20 & 3,4 \\
\hline Não participa & 420 & 71,3 \\
\hline
\end{tabular}

Em relação à utilização de equipamentos sociais verifica-se a partir do quadro 8 que os relacionados à saúde e à igreja (desconsiderando freqüência restrita aos cultos) foram os mais mencionados pelas famílias.

Quadro 7- Distribuição das famílias dos quatro grupos sociais segundo equipamentos sociais utilizados por um ou mais membros. Santo André, SP, 2008.

\begin{tabular}{|l|cc|}
\hline Equipamentos sociais & & \\
\hline & $\mathbf{N}$ & $\mathbf{\%}$ \\
Saúde & 241 & 40,9 \\
Igreja (exceto cultos) & 171 & 29,0 \\
Recreativo/cultural & 64 & 10,9 \\
Creche & 31 & 5,3 \\
Centro de juventude & 12 & 2,0 \\
Outros & 8 & 1,3 \\
Auto-ajuda & 6 & 1,0 \\
\hline
\end{tabular}

Quanto à suficiência ou não de renda para gastos de alimentação verificou-se que 261 famílias $(44,3 \%)$ relataram que a renda é suficiente para despesas básicas de alimentação, vestuário, contas de água e luz. Quase a mesma proporção relatou que a renda é insuficiente $(239-40,6 \%)$ e 89 famílias $(15,1 \%)$ referiram que a renda era mais que suficiente.

Ao se perguntar se havia alguém da família tinha dívidas que não podiam pagar ou nome no Serasa verificou-se que para 171 (29\%) famílias a resposta era afirmativa, sendo que 263 44,65\%) famílias tinham gastos com crediário ou prestações.

Por outro lado 224 famílias (38\%) referiam ter poupança ou outros investimentos. 


\section{Dimensão demográfica}

A dimensão demográfica consiste em elementos que qualificarão os grupos sociais após a definição destes por meio das dimensões de reprodução social (dimensão da produção e do consumo) conforme citado anteriormente

Dessa forma identificou-se que a maior parte dos chefes de família eram homens (433-73,5\%). A maior parte do chefes estava na faixa etária de 45 a 54 anos $(43,8 \%)$, mais da metade eram brancos $(58,2 \%)$ e católicos $(55,9 \%)$ sendo apenas $28,4 \%$ praticantes (Tabelas 15, 16, 17 e 18)

Quanto ao local de nascimento, verificou-se que quase um quarto nasceu no próprio município de Santo André destacando-se que 22,9\% eram procedentes da região Nordeste Tabela 19).

Tabela 15 - Distribuição dos chefes de família segundo faixa etária. Santo André, SP, 2008.

\begin{tabular}{lcc}
\hline Faixa etária & N & \% \\
\hline 2 De 15 a 19 anos & 6 & 1,0 \\
3 De 20 a 24 anos & 33 & 5,6 \\
4 De 25 a 34 anos & 43 & 7,3 \\
5 De 35 a 44 anos & 169 & 28,7 \\
6 De 45 a 54 anos & 258 & 43,8 \\
7 De 55 anos e mais & 80 & 13,6 \\
Total & $\mathbf{5 8 9}$ & $\mathbf{1 0 0 , 0}$ \\
\hline
\end{tabular}

Tabela 16- Distribuição dos chefes de família segundo cor da pele. Santo André, SP, 2008.

\begin{tabular}{lcc}
\hline Raça & $\mathbf{N}$ & $\mathbf{\%}$ \\
\hline Preta & 67 & 11,4 \\
Parda & 167 & 28,4 \\
Branca & 343 & 58,2 \\
Amarela & 6 & 1,0 \\
Indígena & 6 & 1,0 \\
Total & $\mathbf{5 8 9}$ & $\mathbf{1 0 0 , 0}$ \\
\hline
\end{tabular}


Tabela 17 - Distribuição dos chefes de família segundo religião. Santo André, SP, 2008.

\begin{tabular}{lcc}
\hline Religião & $\mathbf{N}$ & $\mathbf{\%}$ \\
\hline Católica & 329 & 55,9 \\
Test. de Jeová & 9 & 1,5 \\
Histórico & 13 & 2,2 \\
Pentecostal & 128 & 21,7 \\
Espírita & 25 & 4,2 \\
Afrobrasileiro & 4 &, 7 \\
Sem religião/culto & 51 & 8,7 \\
Não determinada & 30 & 5,1 \\
Total & $\mathbf{5 8 9}$ & $\mathbf{1 0 0 , 0}$ \\
\hline
\end{tabular}

Tabela 18 - Distribuição dos chefes de família segundo prática religiosa. Santo André, SP, 2008.

\begin{tabular}{lrr}
\hline Prática religiosa & \multicolumn{2}{c}{ N } \\
\hline Católica & 167 & 28,4 \\
Test. de Jeová & 10 & 1,7 \\
Histórico & 12 & 2,0 \\
Pentecostal & 120 & 20,4 \\
Espírita & 19 & 3,2 \\
Afrobrasileiro & 3 &, 5 \\
Religiões Orientais & 1 &, 2 \\
Sem religião/culto & 216 & 36,7 \\
Não determinada & 40 & 6,8 \\
Outras & 1 &, 2 \\
Total & $\mathbf{5 8 9}$ & $\mathbf{1 0 0 , 0}$ \\
\hline
\end{tabular}


Tabela 19 - Distribuição dos chefes de família segundo local de nascimento. Santo André, SP, 2008.

\begin{tabular}{|c|c|c|}
\hline Local de nascimento & $\mathbf{N}$ & $\%$ \\
\hline RMSP & 65 & 11,0 \\
\hline SP Interior & 92 & 15,6 \\
\hline Santo André & 140 & 23,8 \\
\hline $\begin{array}{l}\text { Grande ABC exceto Santo } \\
\text { André }\end{array}$ & 36 & 6,1 \\
\hline Sudeste & 46 & 7,8 \\
\hline Sul & 35 & 5,9 \\
\hline Nordeste & 135 & 22,9 \\
\hline Norte & 19 & 3,2 \\
\hline Centro Oeste & 9 & 1,5 \\
\hline Outro país & 2 & ,3 \\
\hline Não sabe & 10 & 1,7 \\
\hline Total & 589 & 100,0 \\
\hline
\end{tabular}


ANEXO VI 
ANEXO VII 


\section{ANEXO VII \\ INSTRUMENTO PARA APLICAÇÃO DO ÍNDICE DE REPRODUÇÃO SOCIAL Classificação das famílias segundo a dimensão da produção e do consumo}

Dados de identificação: UBS: No. Prontuário da família/ chefe

Nome do chefe de família:

\section{ETAPAS:}

1- Realizar as perguntas a respeito do curso preparatório do trabalho e qualificação da ocupação do chefe da família (segundo referido pelo entrevistado),

2- Escolher a melhor opção de qualificador e registrar o valor ao lado da letra que corresponde à variável (A e B). Consultar o quadro da última página para classificar a ocupação.

\begin{tabular}{|c|c|}
\hline Variáveis da dimensão da produção com seus qualificadores & $\begin{array}{l}\text { Valores dos } \\
\text { qualificadores }\end{array}$ \\
\hline Curso preparatório para o trabalho & (A) \\
\hline Não & 0 \\
\hline Sim & 1 \\
\hline Qualificação da ocupação & (B) \\
\hline Bico, desempregado em ocupação mal definida & 1 \\
\hline $\begin{array}{l}\text { Trabalhador familiar, autônomo ou assalariado sem carteira em ocupação } \\
\text { mal definida }\end{array}$ & 2 \\
\hline $\begin{array}{l}\text { Aposentado, pensionista, afastado do trabalho e empregador ou } \\
\text { assalariado com carteira em ocupação mal definida }\end{array}$ & 3 \\
\hline Bico, desempregado em ocupação do tipo não operacional/ apoio & 4 \\
\hline $\begin{array}{l}\text { Trabalhador familiar, autônomo ou assalariado sem carteira em ocupação } \\
\text { do tipo não operacional/ apoio }\end{array}$ & 5 \\
\hline $\begin{array}{l}\text { Aposentado, pensionista, afastado do trabalho e empregador ou } \\
\text { assalariado com carteira em ocupação do tipo não operacional/apoio }\end{array}$ & 6 \\
\hline Bico, desempregado em ocupação de serviço de escritório & 7 \\
\hline $\begin{array}{l}\text { Trabalhador familiar, autônomos ou assalariados sem carteira em } \\
\text { ocupação de serviços de escritório }\end{array}$ & 8 \\
\hline $\begin{array}{l}\text { Aposentado, pensionista, afastado do trabalho e empregador ou } \\
\text { assalariado com carteira em ocupação de serviços de escritório }\end{array}$ & 9 \\
\hline Bico, desempregado em ocupação de serviços gerais & 10 \\
\hline $\begin{array}{l}\text { Trabalhador familiar, autônomo ou assalariado sem carteira em ocupação } \\
\text { de serviços gerais }\end{array}$ & 11 \\
\hline $\begin{array}{l}\text { Aposentado, pensionista, afastado do trabalho e empregador ou } \\
\text { assalariado com carteira em ocupação de serviços gerais }\end{array}$ & 12 \\
\hline Bico, desempregado em ocupação não qualificado na execução & 13 \\
\hline $\begin{array}{l}\text { Trabalhador familiar, autônomos ou assalariados sem carteira em } \\
\text { ocupação não qualificado na execução }\end{array}$ & 14 \\
\hline $\begin{array}{l}\text { Aposentado, pensionista, afastado do trabalho e empregador ou } \\
\text { assalariado com carteira em ocupação não qualificada na execução }\end{array}$ & 15 \\
\hline Bico, desempregado em ocupação semi qualificada na execução & 16 \\
\hline $\begin{array}{l}\text { Trabalhador familiar, autônomo ou assalariado sem carteira em ocupação } \\
\text { semi qualificada na execução }\end{array}$ & 17 \\
\hline $\begin{array}{l}\text { Aposentado, pensionista, afastado do trabalho e empregador ou } \\
\text { assalariado com carteira em ocupação semi qualificada na execução }\end{array}$ & 18 \\
\hline $\begin{array}{l}\text { Trabalhador familiar, autônomo ou assalariado sem carteira em ocupação } \\
\text { qualificada na execução }\end{array}$ & 19 \\
\hline $\begin{array}{l}\text { Aposentado, pensionista, afastado do trabalho e empregador ou } \\
\text { assalariado com carteira em ocupação qualificada na execução }\end{array}$ & 20 \\
\hline Planejamento e Organização & 21 \\
\hline Empresário, direção e gerência & 22 \\
\hline
\end{tabular}


3- Escolher a melhor opção de qualificador para dimensão do consumo considerando dados da família. Registrar o valor ao lado da letra que corresponde à variável $(\mathrm{C}$ até $\mathrm{I})$.

\begin{tabular}{|l|l|}
\hline Variáveis da dimensão do consumo com seus qualificadores & $\begin{array}{l}\text { Valores dos } \\
\text { qualificadores }\end{array}$ \\
\hline Propriedade da residência & (C) \\
\hline Cedida, Outros & 0 \\
\hline Alugada & 1 \\
\hline Financiada & 2 \\
\hline Própria regular ou irregular & 3 \\
\hline Recebe conta de água? & $(\mathbf{D})$ \\
\hline Não & 0 \\
\hline Sim & 1 \\
\hline Recebe conta de Luz? & $(\mathbf{E})$ \\
\hline Não & 0 \\
\hline Sim & 1 \\
\hline Acesso a serviços público de esgoto & $(\mathbf{F})$ \\
\hline Não & 0 \\
\hline Sim & 1 \\
\hline $\begin{array}{l}\text { Algum membro da família tem como atividade de lazer a ida a } \\
\text { cultos? }\end{array}$ & $(\mathbf{G})$ \\
\hline Não & 0 \\
\hline Sim & 0 \\
\hline Paga IPTU? & 1 \\
\hline Não & $($ H) \\
\hline Sim & 0 \\
\hline Número de cômodos para dormir & 1 \\
\hline Não tem & $(\mathbf{I})$ \\
\hline 1 & 0 \\
\hline 2 & 1 \\
\hline 3 ou mais & 2 \\
\hline & 3 \\
\hline & \\
\hline
\end{tabular}

4- Substituir nas equações abaixo as letras pelos valores atribuídos e realizar as devidas multiplicações e somas:

$\mathbf{G I}=-104,617+(6,403 x \mathrm{~A})+(0,924 \mathrm{xB})+(3,183 \mathrm{xC})+(32,688 \mathrm{xD})+(37,430 \mathrm{xE})+$ $(91,410 x F)+(4,267 x G)+(0,287 x H)+(4,588 x \mathrm{I})$

$\mathbf{G I I}=-91,779+(2,211 \times \mathrm{A})+(0,707 \mathrm{xB})+(2,315 \mathrm{xC})+(33,139 \mathrm{xD})+(39,367 \mathrm{xE})+$ $(89,323 x \mathrm{~F})+(2,911 \mathrm{xG})-(1,402 \mathrm{xH})+(3,009 \mathrm{xI})$

GIII $=-92,493+(1,297 x A)-(0,030 x B)+(2,684 x C)+(35,192 x D)+(39,600 x E)+$ $(89,824 x F)+(3,359 x G)-(1,161 x H)+(4,109 x I)$

GIV $=-25,753+(2,160 x \mathrm{~A})+(0,597 \mathrm{xB})+(2,323 \mathrm{xC})+(13,562 \mathrm{xD})+(20,201 \mathrm{xE})+$ $(32,427 x F)+(3,933 x G)-(0,785 x H)+(2,917 x I)$

5- Classificar a família no grupo que apresentou maior resultado final.

\section{Grupo social:}




\section{TABELA DE OCUPAÇÕES}

\section{DIREÇÃO E PLANEJAMENTO}

1.1. Planejamento e organização

Farmacêuticos, químicos

Arquitetos, engenheiros

Médicos

Dentistas

Estatísticos

Programadores de computadores

Economistas

Contadores e auditores contábeis

Fiscais e técnicos de arrecadação e tributação, advogados e defensores públicos,

Professores de ensino superior, professores pesquisadores

Diretores de escolas, professores de ensino não especificado, técnicos

de ensino, inspetores de alunos, orientadores de ensino.

Arquivologistas, bibliotecários, museólogos, ocupações técnicas e cientificas não especificadas

Antropólogos, Geógrafos, Arqueólogos, Sociólogos, Demógrafos

Chefes e encarregados de seção de serviços administrativos de

empresas

Chefes e encarregados de sessão na produção industrial

1.2. Empresário, direção e gerência

Diretores e produtores de espetáculos

Empresários do comércio

Administradores e gerentes da indústrias de transformação

Administradores e gerentes do comércio e de serviços

Administradores do setor bancário e financeiro

Outros administradores e gerentes não classificados

\section{EXECUÇÃ̃O}

2.1. Não qualificado na execução

Carteiros

Frentistas, repositores de mercadorias

Baleiro, sorveteiros, doceiros, comerciantes ambulantes, bilheteiro, leiteiro, feirante, peixeiro, quitandeiro.

Copeiros, garçons, atendentes de bares e lanchonetes

Camareiros, empregados domésticos

Operadores de máquina de marcenaria

Operadores de máquina na indústria de artefatos de borracha e plástico

Pintores e caiadores

Vidraceiros

\subsection{Semi-qualificado na execução}

Enfermeiros não diplomados

Jogadores de futebol e outros atletas

Inspetores e fiscais, guardas sanitários

Representantes, pracistas e viajantes comerciais

Corretores de títulos de valores, de seguros, de bolsa de valores

e de imóveis

Promotor de vendas e propagandistas

Vendedores

Cozinheiros

Cabeleireiro, manicure, barbeiro, esteticista, maquilador

Vigias particulares, guardas de presídios, carcereiros.

Tecelões, tricoteiros, tapeceiros

Pasteleiro, confeiteiro, padeiro

Costureiros, alfaiates

Bordadeiras, cerzideiras

Sapateiros

Marceneiros

Ferreiros, serralheiros

Furadores, frisadores, retificadores, torneiros mecânicos.

Estampadores mecânicos, operadores de prensa mecânica de metais

Mecânicos sem especificação

Montadores de equipamentos elétricos

Eletricistas de instalações, reparadores de equipamentos elétricos

Operadores de equipamentos de som e cenografia e outros operadores não especificados

Soldadores

Lanterneiros de veículos e funileiros

Rebitadores e montadores de estruturas metálicas

Borracheiros, vulcanizadores e recauchutadores

Impressores e outras ocupações da indústria gráfica

Pedreiros

Caldeireiros, operadores de máquinas (exclusive de agropecuária e construção, operadores de tratamento e bombeamento

Motoristas, operadores de máquinas de construção civil 
Técnicos em estatística, em análise de dados, de contabilidade e pesquisadores de mercado

Técnicos de agropecuária, eletrônica, eletrotécnica, mecânica. enfermagem, análises clínicas.

Técnicos de estradas, de saneamento, edificações, de agrimensura, ocupações auxiliares de engenharia e de arquitetura, desenhistas

Técnicos químicos

Ortoptistas e óticos

Professores de ensino fundamental

Instrutores e professores de formação profissional

Artistas plásticos, escultores, pintores, artesãos

Operadores de câmeras e fotógrafos

Ferramenteiros

Montadores na indústria metalúrgica

Mecânicos de veículos automotores

Ajustadores e montadores mecânicos, lubrificadores

Encanadores

\subsection{Serviços gerais}

Recepcionistas

Porteiros, zeladores, ascensoristas

Faxineiros, serventes, lixeiros

Guardadores de automóveis

3.2. Serviços de escritório

Secretárias

Pagadores, caixas, auxiliares de contabilidade e contas a pagar

\subsection{Não Operacional/apoio}

Oficiais forças armadas, bombeiros, guardas metropolitanos e civis

Telegrafista, radiotelegrafista, telefonista

Despachantes de cargas, ônibus e trens, armazenistas, conferentes de materiais, almoxarifes, estoquistas

Apontador, auxiliares de escritório e administrativos, escriturário.

Instaladores e reparadores de equipamentos e aparelhos de telecomunicação

Operadores de empilhadoras

Condutores e chefes de trem, maquinistas de trem

\section{MAL DEFINIDAS}

Outras ocupações da indústria de transformação Outras ocupações ou ocupações mal definidas 


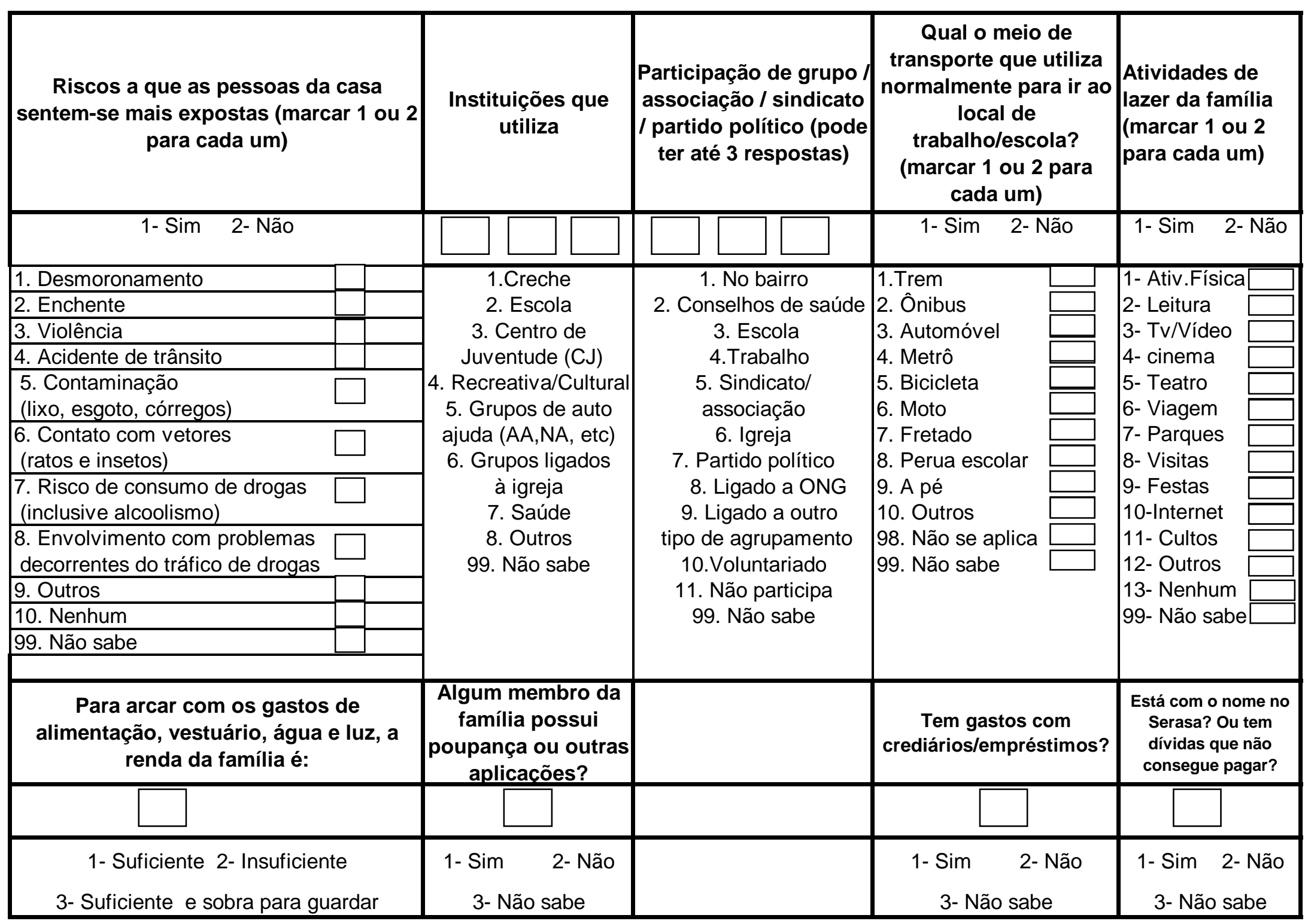




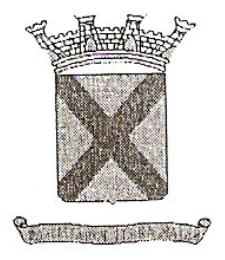

\title{
PREFEITURA MUNICIPAL DE SANTO ANDRÉ
}

\author{
Secretaria de Saúde \\ Comitê de Ética em Pesquisa - CEP
}

Parecer $27 / 2007$

Santo André, 08 de agosto de 2007.

\section{Prezada Senhora}

Informamos que o Comitê de Ética em Pesquisa da Secretaria de Saúde de Santo André APROVOU, de acordo com a resolução 196/96, o protocolo de pesquisa "Jovens, valores e consumo de drogas: políticas públicas na perspectiva da Saúde Coletiva", registro 27/2007 - CEP/SSSA, de autoria da pesquisadora: Cássia Baldini Soares

Salientamos os seguintes aspectos a serem considerados pelo pesquisador:

1) O sujeito da pesquisa tem a liberdade de recusar-se a participar ou de retirar seu consentimento em qualquer fase da pesquisa, sem penalização alguma ou sem prejuízo ao seu cuidado e deve receber uma cópia do Termo de Consentimento Livre e Esclarecido, na íntegra, por ele assinado (Res. CNS 196/96).

2) O pesquisador deve desenvolver a pesquisa conforme delineada no protocolo aprovado. Eventuais modificações ou emendas ao protocolo devem ser apresentadas ao CEP de forma clara e sucinta, identificando a parte do protocolo a ser modificada e suas justificativas.

3) O relatório final da pesquisa deve ser apresentado ao CEP, logo que o estudo estiver concluído.

Atenciosamente

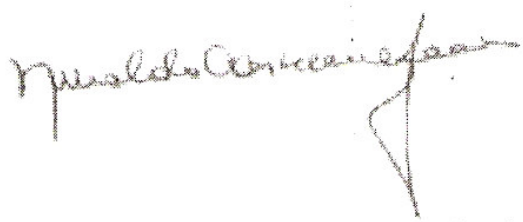

Dr. Nivaldo Carneiro Junior

Coordenador do CEP - SSSA 


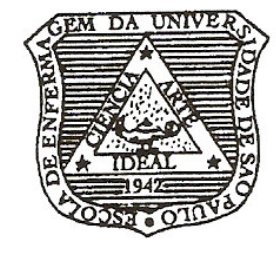

\section{UNIVERSIDADE DE SÃO PAULO ESCOLA DE ENFERMAGEM}

Av. Dr. Enéas de Carvalho Aguiar, 419 - CEP 05403-000

Tone.: 3066-7548 - Fax.: 280-8213

C.P. 41633 - CEP 05422-970 - e-mail.: edipesq@usp.br

São Paulo, 13 de abril de 2006.

$\mathrm{Ilm}^{\mathrm{a}} \mathrm{Sr}^{\mathrm{a}}{ }^{\mathrm{a}}$

Prof. ${ }^{\text {a }}$ Dr. ${ }^{\text {a }}$ Cássia Baldini Soares

$\underline{\text { Ref.: Processo } n^{\circ} \text { 538/2006/CEP-EEUSP }}$

Prezada Senhora,

Em atenção à solicitação referente à análise do projeto "JOVENS, VALORES E CONSUMO DE DROGAS: POLÍTICAS PÚBLICAS NA PERSPECTIVA DA SAÚDE COLETIVA", informamos que o mesmo foi considerado aprovado pelo Comitê de Ética em Pesquisa da Escola de Enfermagem da Universidade de São Paulo (CEP/EEUSP).

Analisado sob o aspecto ético-legal, atende às exigências da Resolução nº 196/96 do Conselho Nacional de Saúde.

Esclarecemos que após o término da pesquisa, os resultados obtidos deverão ser encaminhados ao CEP/EEUSP, para serem anexados ao processo.

Atenciosamente,

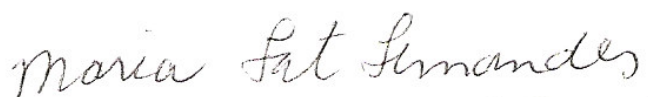

Prof. ${ }^{a}$ Dr. ${ }^{a}$ Maria de Fátima Prado Fernandes

Vice-Coordenadora do Comitê de Ética em Pesquisa da Escola de Enfermagem da Universidade de São Paulo em Exercício 